\title{
Mulheres vivendo com HIV: fatores associados ao planejamento da primeira gravidez após o diagnóstico
}

\section{JEFFERSON SANTOS PEREIRA}

Dissertação apresentada ao Programa de Pósgraduação da Faculdade de Saúde Pública para obtenção do título de Mestre em Ciências.

Área de concentração: Saúde, Ciclos de Vida e Sociedade.

Orientadora: Prof. ${ }^{\text {a }}$ Dra. Cristiane da Silva Cabral

São Paulo

2019 


\section{Mulheres vivendo com HIV: fatores associados ao planejamento da primeira gravidez após o diagnóstico}

\section{JEFFERSON SANTOS PEREIRA}

Dissertação apresentada ao Programa de Pósgraduação da Faculdade de Saúde Pública para obtenção do título de Mestre em Ciências.

Área de concentração: Saúde, Ciclos de Vida e Sociedade.

Orientadora: Prof. ${ }^{a}$ Dra. Cristiane da Silva Cabral

\section{Versão Revisada}

São Paulo

2019 
Autorizo a reprodução e divulgação total ou parcial deste trabalho, por qualquer meio convencional ou eletrônico, para fins de estudo e pesquisa, desde que citada a fonte.

Catalogação da Publicação Biblioteca/CIR:

Centro de Informação e Referência em Saúde Pública

Faculdade de Saúde Pública da Universidade de São Paulo

Dados fornecidos pelo(a) autor(a)

PEREIRA, JEFFERSON

Mulheres vivendo com HIV: fatores associados ao planejamento da primeira gravidez após o diagnóstico / JEFFERSON PEREIRA; orientadora CRISTIANE CABRAL. - São Paulo, 2019.

$191 \mathrm{p}$.

Dissertação (Mestrado) -- Faculdade de Saúde Pública da Universidade de São Paulo, 2019.

1. HIV. 2. GRAVIDEZ NÃO PLANEJADA. 3. ABORTO. 4. MULHERES. 5. DIREITOS SEXUAIS E REPRODUTIVOS. I. CABRAL, CRISTIANE, orient. II. Título. 
À minha querida avó Maria Madalena da Costa Pereira (in memoriam), e minha amada mãe Valderez Santos, minhas fontes de inspiração. 


\section{Agradecimentos}

Agradeço à Deus pela dádiva da vida e por estar sempre ao meu lado. Agradeço pela proteção e direcionamento durante toda a minha trajetória, repleta de tentativas, planos, erros e acertos, mas sempre com a certeza de que eu não estava só. Em cada passo que eu dei, e em cada escolha que fiz, tive a certeza de Seu apoio e cuidado sobre minha vida.

À professora Cristiane da Silva Cabral, pela orientação, dedicação e por ser um exemplo de profissionalismo e humanidade. Por sempre ter sido solícita, ética e importar-se não somente com a execução desse trabalho, mas comigo enquanto ser humano. Obrigado pelos ensinamentos, pelas trocas de experiências, pelos conselhos e pelo apoio que foi primordial para chegar até aqui. Obrigado por se tornar uma amiga e parceira de luta em dias tão difíceis.

Às professoras Maria do Rosário, Regina Barbosa e Wilza Vieira Villela, que gentilmente aceitaram compor a banca examinadora dessa dissertação. Agradeço ainda as professoras Maria do Rosário e Regina Barbosa por me ajudarem desde a qualificação, contribuindo para a delimitação do objeto de estudo dessa pesquisa.

Aos professores da Faculdade de Saúde Pública, pela competência e ensinamentos compartilhados. Em especial, agradeço a professora Áurea lanni, com quem tive minha primeira experiência na área da pesquisa científica através do projeto de Tutoria Científico-acadêmica, projeto que infelizmente foi encerrado no ano de 2014 na Universidade de São Paulo. Essa primeira aproximação com esse universo, até então desconhecido, foi essencial para minha escolha de seguir no campo da pesquisa científica.

As alunas do departamento de Saúde, Ciclos de Vida e Sociedade, Paula Morena, Paula Galdino, Raquel Zanelatto, Helena e Aline, pelas conversas, compartilhamento de saberes e experiências que me ajudaram desde o projeto à finalização dessa dissertação de mestrado. Agradeço especialmente a Paula Morena por tantas conversas em momentos difíceis que foram renovadoras e fortalecedoras.

A amiga Stella Verzinhasse por se manter sempre disponível para esclarecer dúvidas que me ajudaram muito na execução das análises 
estatísticas.

As amigas de trabalho do Registro de Câncer de Base Populacional de São Paulo, Adriana, Aryane, Thamires, Iza, Lucinda, Rose, Léa, Cidinha, Rita, Nazaré e Márcia pelas palavras de motivação e apoio sempre constantes. Agradeço de maneira especial a Aryane, por estar sempre ao meu lado me motivando e apoiando, sua amizade foi muito importante nesse momento da minha vida.

Aos amigos da pós-graduação, João, Marcela e Thaís pela parceria nos estudos, realização de trabalhos, trocas de experiências e apoio, compartilhamos dificuldades, angústias, mas, acima de tudo, fortalecemos uns aos outros, nesse momento comum a todos nós.

Aos amigos da graduação em Saúde Pública, Márcio, Ana Carolina, Larissa, Michele, Priscila, Aline, Tatiane e Marta, que se mantiveram presentes nesse momento desafiador.

Aos amigos, Álvaro, Dan, Gabrielle e Kesia, pessoas que admiro tanto, que sempre me motivaram a seguir no caminho da pesquisa científica, além de estarem sempre dispostos a ouvir minhas angústias e preocupações.

Aos meus familiares, irmãos, primos e tios pelas palavras de motivação e por todo o apoio e amor recebido em todos esses anos.

A minha mãe Valderez que é a maior razão da minha dedicação aos estudos e desejo de mudar a vida. Com seu jeito simples e incondicional amor, me motivou a ser o homem que sou hoje.

Ao meu amado marido Junior, pela parceria e paciência, por sempre me motivar e entender meus momentos difíceis, com certeza esse percurso se tornou mais leve com seu apoio.

Por fim, agradeço especialmente as mulheres vivendo com HIV/Aids que se dispuseram a responder o questionário da pesquisa GENIH, compartilhando suas histórias, para que trabalhos como esse fossem desenvolvidos. 
"Se você é capaz de tremer de indignação a cada vez que se comete uma injustiça no mundo, então somos companheiros."

Che Guevara 


\section{RESUMO}

Pereira, J.S. Mulheres vivendo com HIV: Fatores associados ao planejamento da primeira gravidez após o diagnóstico. Dissertação (Mestrado em Saúde pública) - Faculdade de Saúde Pública, Universidade de São Paulo, São Paulo, 2019.

Este trabalho teve como objetivo descrever o perfil de mulheres vivendo com HIV que tiveram pelo menos uma gravidez após o diagnóstico e verificar os fatores associados ao planejamento da primeira gestação após o diagnóstico de HIV. Utilizaram-se dados da pesquisa de delineamento transversal "GENIH: Gênero e Infecção pelo HIV", um estudo com amostra probabilística que entrevistou mulheres de 18 a 49 anos, usuárias de serviços públicos de saúde no município de São Paulo. Neste estudo, foi analisada uma subamostra de 308 mulheres vivendo com HIV e com, pelo menos, uma gestação após o diagnóstico. A análise dessas mulheres foi segmentada a partir do planejamento da primeira gravidez após o diagnóstico do HIV: 31,3\% dessas participantes declararam ter planejado a primeira gestação após o diagnóstico, enquanto $68,7 \%$ declararam não o ter feito. Foi realizado um modelo de regressão logística múltipla, em que os fatores estatisticamente associados ao planejamento da primeira gestação após o diagnóstico $(p \leq 0,05)$ foram: coabitar com parceiro; ausência de aborto provocado antes do diagnóstico por HIV; e ter filho antes do diagnóstico pelo HIV. Tais resultados nos mostram que os fatores associados ao planejamento da gravidez no contexto do HIV são, em certa medida, similares aos fatores associados ao planejamento da gravidez na população em geral. Contudo, nota-se que a proporção de gravidez não planejada para mulheres vivendo com HIV foi maior do que a média geral do Brasil, a qual é de aproximadamente em torno de $55 \%$. Essa alta proporção, por si só, já produz um quadro preocupante e desafiador, especialmente, por se tratar de mulheres inseridas em serviços de saúde especializados e no fato de que os riscos para transmissão vertical do HIV podem ser mais bem controlados em cenários nos quais a gravidez é planejada e acompanhada desde o início.

Palavras-chave: HIV. Direitos Sexuais e Reprodutivos. Gravidez não planejada. Aborto. Mulheres. 


\begin{abstract}
Pereira, J.S. Women living with HIV: Factors associated with planning the first pregnancy after diagnosis. Dissertation (Master in Public Health) - Faculty of Public Health, University of São Paulo, São Paulo, 2019.
\end{abstract}

The present study aimed to describe the profile of women living with HIV who had at least one pregnancy after HIV diagnosis and to verify the factors associated with planning the first pregnancy after it. Data from the crosssectional study "GENIH: Gender and HIV Infection" was used, a study with a probabilistic sample that interviewed women aged 18 to 49 years, who use public health services in the city of São Paulo. For the present study, 308 women living with HIV and at least one gestation after HIV diagnosis were analyzed. The analysis of these women was segmented from the planning of the first pregnancy after HIV diagnosis: $68.7 \%$ of these participants reported having planned their first pregnancy after diagnosis, while $31.3 \%$ stated that they had not. A multiple logistic regression model was performed, in which the factors statistically associated with planning the first pregnancy after diagnosis $(p \leq 0.05)$ were: cohabit with partner; absence of induced abortion prior to HIV diagnosis; and having a child prior to HIV diagnosis. These results show that the factors associated with planning for pregnancy in the context of HIV are similar to the factors associated with planning the pregnancy in the general population, but it is noted that the proportion of unplanned pregnancies for women living with HIV was higher than the general average of Brazil, which is $55 \%$. This high proportion alone creates a worrying and challenging picture, especially when it is thought that women are involved in specialized health services, and the fact that risks for vertical HIV transmission can be better controlled in settings where pregnancy is planned and monitored from the start. However, there are similarities between the elements that compose trajectories of greater vulnerability to unplanned pregnancies and the elements that make up trajectories of greater vulnerability to HIV, such as the occurrence of induced abortion in the trajectory and low level of schooling observed in the study population.

Key words: Sexual and Reproductive Rights. Unplanned pregnancy. Abortion Women. 


\section{LISTA DE TABELAS}

Tabela 1 - Distribuição numérica (n) e percentual (\%) da população do estudo segundo raça/cor, escolaridade e idade atual e idade no diagnóstico.

Tabela 2 - Resultados do teste de associação pelo qui-quadrado das variáveis independentes, em relação ao desfecho gravidez planejada.

Tabela 3 - Resultados de ODDs Ratio bruta, obtidos pela regressão logística univariada.

Tabela 4 - Resultadas de Odds Ratio bruta e ajustada, obtidos pelo modelo de regressão logística múltipla. 


\section{LISTA DE SIGLAS E ABREVIATURAS}

ABIA - Associação Brasileira Interdisciplinar de Aids

ACTG - AIDS Clinical Trials Group

AIDS - Acquired Immunodeficiency Syndrome ARV - Antirretroviral

AZT - Azidotimidina (zidovudina)

CDC - Centers for Disease Control and Prevention's

CID - Classificação Internacional de Doenças

CIPD - Conferência Internacional sobre População e Desenvolvimento

DIAHV - Departamento de Vigilância, Prevenção e Controle das IST, Aids e das Hepatites Virais

DSDR - Direitos Sexuais e Direitos Reprodutivos

DST - Doença Sexualmente Transmissível

ESF - Estratégia Saúde da Família

FIOCRUZ - Fundação Oswaldo Cruz

FSP - Faculdade de Saúde Pública

GENIH - Gênero e Infecção pelo HIV

GRID - Gay-Related Immune Deficiency

HIV - Vírus da Imunodeficiência Humana

$\mathrm{HSH}$ - Homens que fazem Sexo com Homem

HVTN - HIV Vaccine Trials Network

IBGE - Instituto Brasileiro de Geografia e Estatística

I=I - Indetectável igual à Intransmissível

IST - Infecções Sexualmente Transmissíveis

MDB - Movimento Democrático Brasileiro MS - Ministério da Saúde

MVHA - Mulheres Vivendo com HIV/Aids

MNVHA - Mulheres Não Vivendo com HIV/Aids

OMS - Organização Mundial da Saúde

ONG - Organização Não Governamental

ONU - Organização das Nações Unidas

PAISM - Programa de Assistência Integral à Saúde da Mulher

PECAP - Pesquisa sobre Comportamento, Atitudes e Práticas Relacionadas

às DST e Aids da População Brasileira de 15 a 64 anos de idade 
PEP - Profilaxia Pós - Exposição

PNAISM - Política Nacional de Atenção Integral à Saúde da Mulher

PNDS - Pesquisa Nacional de Demografia e Saúde

PrEP - Profilaxia Pré-Exposição

SIM - Sistema de Informações sobre Mortalidade

SPSS - Statistical Package for the Social Sciences

TARV - Tratamento Antirretroviral

TCLE - Termo de Consentimento Livre e Esclarecido

UNFPA - Fundo de População das Nações Unidas

UNAIDS - Joint United Nations Program on HIV/AIDS

UNIFESP - Universidade Federal de São Paulo

USP - Universidade de São Paulo 


\section{SUMÁRIO}

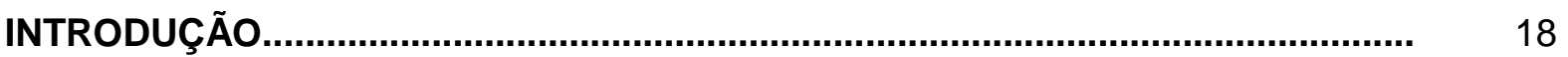

1.1. As quatro décadas da epidemia de HIV/Aids.................................... 21

1.2. Epidemia do HIV/Aids e o planejamento reprodutivo.......................... 40

2. OBJETIVOS

.1. Objetivo Geral.......................................................................................... 53

2.2. Objetivos Específicos.................................................................... 53

3.METODOLOGIA............................................................................................

3.1. Desenho do estudo, estratégia amostral e procedimento de campo... 54

3.2. População do Estudo....................................................................... 55

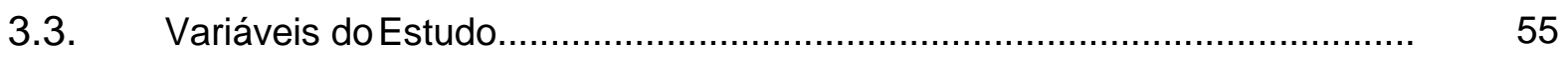

3.4. Análise Estatística................................................................................... 58

3.5. Considerações Éticas............................................................................... 59

4. RESULTADOS

4.1. Análise Bivariada............................................................................... 61

4.2. Modelo de Regressão Logística Univariada................................................. 65

4.3. Modelo de regressão logística múltipla......................................................... 68

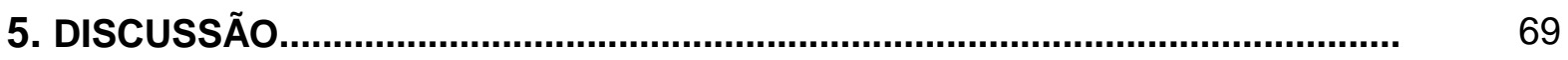

6. CONSIDERAÇÕES FINAIS......................................................................

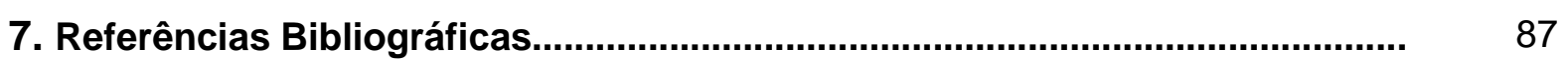

$\begin{array}{ll}\text { ANEXOS } & 99\end{array}$

ANEXO A - Questionário GENIH .................................................................... 100

ANEXO B - Pareceres consubstanciados CEP(s) ………................................. 172

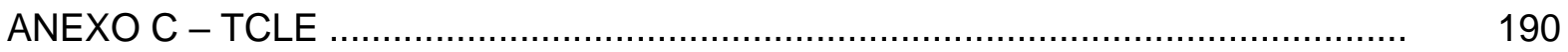




\section{APRESENTAÇÃO}

Ingressei na Faculdade de Saúde Pública da Universidade de São Paulo no ano de 2013, quando iniciei os estudos na graduação em Saúde Pública. Nos primeiros meses do curso, tive a oportunidade de participar do projeto de Tutoria Científico-acadêmica da USP, um projeto que era destinado a alunos ingressantes, com o objetivo de oferecê-los a possibilidade de entrar em contato com o universo da pesquisa acadêmica. Nesse projeto, fui orientado pela professora Áurea Maria Zolner lanni do Departamento de Práticas de Saúde Pública, atual Departamento de Política e Gestão. Trabalhamos em uma pesquisa de um ano, que tinha por objetivo identificar as especificidades da constituição do SUS no município de São Paulo, na perspectiva histórico-social. Essa primeira experiência com a pesquisa acadêmica, proporcionou a mim uma afinidade com o universo científico logo no primeiro ano da graduação.

Desde o início dos meus estudos no curso de Saúde Pública me identifiquei com a multidisciplinaridade ali existente, que perpassa por disciplinas biológicas, exatas, ciências sociais e humanas. Esse perfil específico do curso de Saúde Pública dá aos alunos a chance de atuar em áreas distintas. Não por acaso, a partir da bagagem que adquiri durante a graduação, pude optar, desde o período em que realizei minha iniciação científica, por estudar temas que me permitissem unir diversos campos do saber e que abrangessem, simultaneamente, aspectos biológicos, sociais, políticos e epidemiológicos.

No terceiro ano da graduação, após a conclusão de diversas disciplinas, comecei a me identificar com diversas questões relativas ao campo da saúde e direitos humanos, mais precisamente, pela temática do gênero, sexualidade e saúde. Foi nesse período que iniciei minha iniciação científica sob orientação da professora Cristiane da Silva Cabral. O estudo que realizamos foi intitulado "Iniciação sexual de mulheres com HIV/Aids". Tratou-se de uma investigação epidemiológica de delineamento transversal 
que examinou os determinantes relacionados à iniciação sexual de duas gerações de mulheres, as mais jovens, com socialização para a sexualidade após o início da epidemia de HIV no Brasil, e as mais velhas, nascidas e socializadas antes da epidemia do HIV. Estudo foi realizado com os dados da pesquisa GENIH (Gênero e Infecção pelo HIV) - uma investigação sobre "Práticas e decisões relativas à saúde sexual e reprodutiva no contexto da epidemia de HIV/AIDS no município de São Paulo", conduzido pelo Núcleo de Estudos de População - NEPO da UNICAMP, em parceria da FSP/USP. É também no âmbito desta investigação mais ampla que se situa a presente dissertação de mestrado.

Ainda durante a graduação, tive a oportunidade de entrar para a equipe de trabalho do Registro de Câncer de Base Populacional de São Paulo (RCBP-SP), instituição conveniada à Secretaria de Saúde da prefeitura municipal que coleta e analisa dados referentes aos casos incidentes de câncer no município de São Paulo. Essa oportunidade me proporcionou um grande aprendizado, principalmente no âmbito da epidemiologia e estatística. Atualmente, atuo como analista de dados no RCBP-SP, atividade que contribuiu para minhas escolhas na perspectiva da pesquisa acadêmica.

No ano de 2016, no período de estágios obrigatórios da graduação, houve a oportunidade de estar no Centro de Referência e Treinamento em DST/Aids (CRT- Aids) Estadual de São Paulo, onde passei por diversas áreas e possibilitou a aproximação de questões relacionadas ao HIV, desde as políticas de prevenção e cuidado, até a produção e análise de dados afins. Esta foi uma experiência enriquecedora que pode agregar conhecimentos e proporcionar amadurecimento profissional.

Quando ingressei na pós-graduação, optei por não concorrer ao recebimento de bolsa estudantil para a realização do mestrado e continuar atuando no RCBP-SP. Esse fato me possibilitou vivenciar entre os anos de 2017 e 2018 a oportunidade de atuar como coletador de dados no Projeto de Vinculação e Retenção de Pessoas Vivendo com HIV, o qual é fruto de uma parceria entre a Secretaria de Saúde Municipal de São Paulo, Fundação Faculdade de Medicina e a ONG Aids Healthcare Foundation (AHF). Essa 
experiência me deu a chance de trabalhar com temas que são do meu interesse, que é o caso do HIV/Aids e a análise de dados epidemiológicos.

Considero que ao longo da minha trajetória, tive um caminho consistente e repleto de oportunidades relacionadas aos temas em que me interesso por pesquisar. Sem dúvida, tais experiências me motivaram a seguir no campo da pesquisa. Assim, ainda durante a conclusão do curso de Saúde Pública, me inscrevi para a seleção do mestrado do Programa de Saúde Pública da FSP - USP. Meu projeto inicial era dar continuidade ao que havia realizado na iniciação científica.

Entretanto, após ingressar no mestrado, novamente sob a orientação da professora Cristiane da Silva Cabral, optamos por outro caminho, ainda que dentro da temática do HIV/Aids, mas com mudanças substanciais. A riqueza dos dados da Pesquisa GENIH possibilitou que eu adentrasse nas discussões sobre direitos reprodutivos de mulheres infectadas com HIV, tema deste estudo.

Esta dissertação está organizada em cinco partes principais. No capítulo introdutório, faço um levantamento do quadro evolutivo das quatro décadas da epidemia de HIV/Aids no Brasil. Em seguida, apresento elementos relativos a epidemia do HIV na população feminina, bem como os aspectos que compõem a relação entre o contexto do HIV e a dimensão do planejamento reprodutivo das mulheres vivendo com HIV. Os aspectos metodológicos, as escolhas e operacionalização das variáveis utilizadas e as análises estatísticas realizadas são pormenorizadas no capítulo dois. Como é de praxe nos manuscritos da área da saúde, há um capítulo dedicado aos resultados (capítulo três), onde apresento as análises realizadas a partir da eleição de seis dimensões da vida das mulheres. Acreditamos que elas puderam subsidiar as discussões sobre a primeira gravidez após o diagnóstico de HIV, as quais são então apresentadas no capítulo quatro. Nele, argumento que a dimensão da saúde reprodutiva não é uma área isolada da vida das mulheres, sobretudo quando se trata do planejamento de uma gravidez. Há diversos elementos relacionados a esse contexto, o qual se complexifica ainda 
mais no contexto do HIV/Aids. Por fim, faço um balanço sobre o estudo, potencialidades e limites enfrentados no âmbito das decisões reprodutivas de mulheres vivendo com HIV, precisamente no que tange a primeira gravidez após o diagnóstico. Em seguida, listo as referências bibliográficas utilizadas neste trabalho.

Espero que o/a leitor/a possa ter uma dimensão sobre a multiplicidade de realidades sociais e a influência desses contextos no âmbito da saúde reprodutiva de mulheres vivendo com HIV/Aids. 


\section{INTRODUÇÃO}

O foco deste estudo é a análise da primeira gestação de mulheres vivendo com HIV após o diagnóstico do vírus. Essas mulheres foram entrevistadas em uma investigação mais ampla sobre as trajetórias sexual e reprodutiva de mulheres brasileiras vivendo com HIV/Aids (MVHA) (BARBOSA et al., 2016).

A descoberta da infecção pelo HIV pode produzir implicações diversas na vida de diferentes sujeitos, uma vez que a epidemia não ocorre de forma homogênea, sobretudo no Brasil (PARKER; CAMARGO Jr; 2000). A imagem que se tem da Aids ainda é carregada de estigmas e preconceitos. A epidemia de HIV é também uma epidemia ideológica, socialmente construída. Este fato contribui para que a vida de diversos indivíduos que descobrem a soropositividade para o HIV se complexifique, tanto no campo das decisões e escolhas individuais, quanto na dimensão relacional em diversos aspectos, desde a relação familiar e as relações afetivo-sexuais. No caso das mulheres, em especial, a infecção por HIV pode produzir efeitos também na dimensão das decisões reprodutivas (TERTO JR, 2002; PARKER 2015; BARBOSA et al. 2016).

O cenário político e social em que este estudo se desenvolve é multifacetado, com tensões e contradições. Há mudanças importantes na forma de pensar e viver a sexualidade e a reprodução, a partir da década de 1980, com a emergência da epidemia de HIV/Aids (VANCE, 1995). Na segunda década da epidemia, ocorreram profundas mudanças no perfil epidemiológico do HIV, com crescente feminização, juvenilização e pauperização. Paralelamente, há avanços terapêuticos que possibilitaram uma sobrevida cada vez maior às pessoas soropositivas. $O$ tratamento às pessoas infectadas é oferecido, no Brasil, pelo Sistema Único de Saúde - SUS (no caso dos medicamentos, o fornecimento é feito exclusivamente pelo SUS) e está disponível gratuitamente nos serviços públicos de saúde, desde 1990 (MARQUES, 2003). 
No Brasil, no ano de 2017, foram diagnosticados mais de 42 mil novos casos de HIV e mais de 37 mil novos casos de Aids - dados dos sistemas de notificação nacional. A taxa atual de detecção da Aids no país é de 18,3/100.000 habitantes (2017), totalizando, no período de 1980 a junho de 2018, 982.129 casos de Aids detectados no país. Desde o ano de 2012, observa-se uma diminuição na taxa de detecção de Aids, que passou de 21,7/100.000 habitantes (2012) para 18,3/100.000 habitantes em 2017, configurando um decréscimo de $15,7 \%$. Essa redução tem sido mais acentuada desde a recomendação do "tratamento para todos", política pública implementada em dezembro de 2013. Também em 2017, foram registrados no Sistema de Informações sobre Mortalidade - SIM - mais de 11.400 óbitos, por causa básica Aids (CID10: B20 a B24), com uma taxa de mortalidade padronizada de 4,8/100.000 habitantes. A taxa de mortalidade padronizada sofreu decréscimo de 15,8\% entre 2014 e 2017 - também, possivelmente, em consequência da recomendação do "tratamento para todos" e da ampliação do diagnóstico precoce da infecção pelo HIV (BRASIL, 2018).

No caso da população feminina, no qual o diagnóstico ocorre predominantemente, na gestação, devido ao fato de o teste rápido para o HIV integrar o conjunto de exames preconizados no pré-natal, observaram-se mais de 116 mil novos casos em gestantes no período de 2000 a junho de 2018 . De acordo com as informações do último boletim epidemiológico de HIV/Aids nacional, em um período de dez anos, houve um aumento de 21,7\% na taxa de detecção de HIV em gestantes. Enquanto no ano de 2007, a taxa observada foi de 2,3 casos/mil nascidos vivos, no ano de 2017, essa taxa passou para 2,8 casos/mil nascidos vivos. Esse aumento pode ser explicado, ao menos em parte, pela ampliação do diagnóstico no pré-natal e a consequente melhoria da prevenção da transmissão vertical do HIV (BRASIL, 2018). Em relação a taxa de diagnósticos de HIV por transmissão vertical, entre os anos de 2007 a 2017, registra-se uma tendência de queda de $42,7 \%$ (BRASIL, 2018).

Esses aspectos imprimem novos contornos à epidemia, que, desde o início do século XXI, tem sido classificada como uma doença crônica. Trata- 
se de um momento específico no curso da epidemia que aporta outros desafios, sobretudo no que concerne aos efeitos do vírus sobre a vida íntima das pessoas e sobre a (re)organização de suas biografias afetivo-sexualreprodutivas (KNAUTH, 1999).

Esta dissertação tem como objetivo examinar os perfis das mulheres com pelo menos, uma gestação após o diagnóstico do HIV, e os contextos associados a tal evento reprodutivo, com vistas a identificar e discutir os condicionantes relacionados ao planejamento da primeira gestação após o diagnóstico do HIV. O contexto mais amplo traz as marcas das mudanças relativas ao cenário da gestão da sexualidade e da reprodução, nestas últimas quatro décadas, no campo da epidemia de HIV/AIDS.

Um breve levantamento do quadro evolutivo da epidemia HIV/AIDS nos revela tanto diferenças quantitativas, quando observamos as mudanças no perfil epidemiológico dos que estão diretamente afetados pelo HIV, quanto qualitativas, sobretudo quando são discutidas, por exemplo, questões sociais pelo prisma de gênero, religião, intervenções políticas nos programas de prevenção e controle da epidemia (SHEFFER; ROSENTHAL, 2009). Os desafios e as perspectivas se transformaram ao longo do tempo, e os números expressam apenas uma parte do cenário social em que se apresentam (TERTO JR., 2002).

Os estudos sobre os efeitos do diagnóstico de HIV nas trajetórias reprodutivas de mulheres ainda são escassos. Entretanto, algumas pesquisas vêm buscando identificar e dimensionar tais efeitos. Teixeira e colaboradores (2017) realizaram uma investigação sobre os fatores relacionados a gravidez após o diagnóstico em mulheres vivendo com HIV/Aids. Os autores afirmam que a dimensão da saúde reprodutiva de mulheres com diagnóstico de HIV é interpelada não apenas tanto pelas questões gerais que envolvem os significados de ser mulher na sociedade, mas também pelas particularidades da experiência relacionada ao vírus.

Knauth (1999) realizou um estudo acerca da relação entre diagnóstico de HIV e a construção da identidade social de mulheres na década de 1990. Segundo a autora, a identidade social feminina foi fundamental para a 
compreensão dos efeitos da infecção pelo HIV na dimensão sexual e reprodutiva na vida das mulheres. Para a maior parte das mulheres que foram infectadas no contexto de uma parceria fixa, por exemplo, a contaminação era vista como um destino social, fruto do papel de esposa exercido pela mulher. Para essas mulheres, o HIV era colocado de forma secundária de modo que a vida conjugal e os projetos de família continuaram sendo prioridades e a doença se subordinaria a tais questões. Segundo a autora, as mulheres reuniam esforços para "resgatar o status social ameaçado pela doença" (KNAUTH, 1999, p. 134). Contudo, as mulheres que se infectaram no contexto de parcerias eventuais buscavam reconfigurar seus projetos de vida e família após o diagnóstico, principalmente com o objetivo de manter uma identidade social não condenável (KNAUTH, 1999).

Apesar da comprovada efetividade de procedimentos para impedir a transmissão vertical do vírus HIV, as decisões reprodutivas podem se transformar após a infecção pelo HIV para diversas mulheres. A preocupação com a própria saúde, a preocupação com a saúde e com o futuro da criança, além de outras possíveis questões pessoais, são alguns dos elementos que podem influenciar as mulheres em tais decisões (TEIXEIRA et al. 2013). Assim, considera-se oportuno identificar as questões relacionadas ao planejamento da primeira gestação dessas mulheres após serem diagnosticadas com HIV, considerando que este é um momento crucial e revelador sobre os possíveis efeitos do HIV na dimensão da saúde reprodutiva. Optamos como ponto de partida para esta discussão a caracterização das quatro décadas da epidemia de HIV no Brasil (VILLELA e BARBOSA et al, 2012; SHEFFER, 2012; BAROBOSA; PINHO; CABRAL, 2016).

\subsection{As quatro décadas da epidemia de HIV/Aids}

A década de 80 , principalmente nos países desenvolvidos, era marcada no campo da saúde por um grande otimismo médico (principalmente pelo prisma da biomedicina ocidental moderna), sobretudo nos relatórios e 
avaliações dos Estados Unidos. Havia um tom confiante, que construía um ideário de que tudo, no campo das doenças infecciosas, estava sob controle. Nesse contexto, desconsideravam-se as diferenças regionais e socioeconômicas na ocorrência de doenças e a própria transição epidemiológica. A ênfase era dada à esperança de um intenso progresso que propiciaria "saúde" para todos na virada do século (BASTOS, 2002). O olhar biomédico excluía especificidades e aspectos sociais relevantes para os processos saúde-doença, bem como as questões culturais e subjetivas relacionadas à sexualidade. Essa "cegueira cultural" impacta diretamente nos desdobramentos para compreender uma epidemia misteriosa (VANCE, 1995). A chegada de uma síndrome devastadora de alta periculosidade causa uma interrupção intensa deste otimismo médico que, desconhecendo as armas necessárias para a vitória, tornava este campo de batalha uma incógnita e, a guerra, longe de ser vencida (BASTOS, 2002).

Esse é o contexto mais amplo em que se situa a história da AIDS. As discussões acerca de uma doença misteriosa têm início nos Estados Unidos em 1980, precisamente nas cidades de Nova York, Los Angeles e São Francisco, diante da constatação de uma estranha síndrome que acometia, sobretudo, pacientes homossexuais masculinos com um conjunto de sintomas peculiares (Sarcoma de Kaposi e Pneumonia pelo Pneunocistis carinii):

A pneumocistose, por exemplo, ocorria em pacientes com câncer em estágios avançados (foi a doença que atingiu a médica dinamarquesa ${ }^{1}$ ); já o Sarcoma de Kaposi era bem conhecido entre idosos procedentes da bacia do mediterrâneo. Eles nunca haviam sido observados até então, ao mesmo tempo, em pacientes homossexuais masculinos sem histórico de outras doenças" (Bibliomed, 2013).

\footnotetext{
${ }^{1}$ A médica e pesquisadora dinamarquesa Margrethe P. Rask faleceu em 12 de dezembro de 1977 de uma doença que a deteriorou rapidamente. Rask esteve na África, estudando sobre - Ebola, e quando começou a apresentar diversos sintomas estranhos para a sua idade. A autopsia do seu corpo revelou que os pulmões estavam repletos de microorganismos, que ocasionaram um tipo de pneumonia e vieram a asfixia-la. Contudo, a pergunta que pairava era: ninguém morria em função disso, o que estaria acontecendo? Historicamente, talvez esse seja o primeiro caso descrito de morte por decorrência da AIDS.
} 
A partir deste quadro, o Centers for Disease Control and Prevention (CDC), órgão de vigilância epidemiológica norte-americano, começa a estudar a doença para definir seu perfil clínico e epidemiológico. Como os primeiros casos notificados foram, predominantemente, em homossexuais, havia a suspeita de que a doença se relacionava a determinado estilo de vida (Bibliomed, 2013). No Brasil, o primeiro caso diagnosticado foi em 1982 na cidade de São Paulo, mesmo ano em que se registra o primeiro caso de AIDS decorrente de transfusão sanguínea (BRASIL, 2015).

\section{A primeira década da epidemia ou a "doença dos $5 \mathrm{H}$ "}

A vinculação dos primeiros casos de AIDS aos homossexuais repercutiu em uma caracterização da doença pela delimitação da população acometida. A mídia se referia a AIDS como um "câncer gay", "pneumonia gay" e, até mesmo, uma "peste gay". Diversos cientistas consideravam apropriado utilizar o termo Gay Related Immunodeficiency (GRID). Mais do que colocá-

los como vulneráveis, tais discursos traziam uma carga moral intensa em diversos sentidos: a doença seria uma consequência dos ideais gays, como a liberdade sexual, sendo a Aids uma punição por tais comportamentos. A AIDS

era, assim, vista como um castigo para banir o mal da sociedade (os homossexuais e os discursos sobre liberação sexual) ou ainda, como uma punição divina àqueles com comportamentos promíscuos (PINHEIRO, 2015).

O quadro inicialmente delineado em termos de pessoas mais suscetíveis/vulneráveis para serem acometidos pela doença foi composto, então, por cinco grupos de risco específicos, a saber: homossexuais, hemofílicos, haitianos, heroinômanos (usuários de heroína injetável) e hookers (nome em inglês dado às profissionais do sexo). Assim, a AIDS teve temporariamente o codinome de "Doença dos cinco H" (Pinheiro 2015).

Segundo Bastos (2002), desde o início a epidemia de HIV/AIDS no Brasil possuía características distintas, o que impulsionou os militantes das ONG's do país a se recusarem a caracterizá-la sob a égide dos padrões internacionais predefinidos. Chamava-se atenção para 0 fato de haver especificidades da epidemia no contexto nacional e clamava-se por 
prioridades de investimentos e de estudos.

Ainda neste período, ao estudar a sexualidade do Brasil para muito além do prisma biológico, o antropólogo Richard Parker identifica que a diversidade com que as concepções sobre sexualidade se apresentam na sociedade ultrapassam os limites do modelo dicotômico, então adotado no mundo como "heterossexuais e homossexuais" (BASTOS, 2002). Parker acaba influenciando e incentivando pesquisadores e organizações a também olharem as peculiaridades da "cultura sexual brasileira" (PARKER, 1993), o que acaba impactando diretamente nos desdobramentos da epidemia, principalmente nos anos seguintes, com a maior participação das ONGs no processo de desenvolvimento de políticas públicas para o combate ao HIV/Aids no país (PINHEIRO,2015; BASTOS, 2002).

Assim como ocorreu em diversos países, a epidemia da Aids chega ao Brasil antes mesmo dos primeiros casos da, até então, doença estrangeira. Ela se constitui rapidamente como um fenômeno político-ideológico, uma "epidemia do preconceito" da doença propriamente dita. Os homossexuais são considerados o principal grupo de risco (quase que exclusivo neste momento), e as ações de prevenção são decorrentes desta premissa. Veiculava-se publicamente, com linguagem repressora e grosseira, métodos de prevenção centrados na estratégia de diminuição da promiscuidade. Logo, pressupunha-se que ser gay era sinônimo de ser promíscuo, e recomendavase, a este público, a diminuição do número de parceiros sexuais, o conhecimento prévio da história sexual do parceiro ou, simplesmente, que abdicassem da atividade sexual (PINHEIRO, 2015; BASTOS, 2002).

Apesar da existência de casos em hemofílicos, inclusive crianças, usuários de drogas injetáveis, pessoas que se submeteram a transfusões de sangue, além de mulheres, as informações disseminadas através da mídia, na década de 80 , somada ao desconhecimento científico sobre as reais formas de contágio da Aids nos anos iniciais da epidemia, criaram um cenário em que a Aids era uma doença que acometia apenas homossexuais. Nesse sentido, o HIV/Aids não era uma preocupação da população heterossexual 
(BARATA, 2006). Se a Aids não era uma questão para os heterossexuais, naquele momento, não havia nenhuma relação sequer com a dimensão da reprodução.

Diante de um cenário de profunda complexidade, a posição dos ativistas militantes da comunidade gay era dupla: era necessário trabalhar intensamente para a dissociação da AIDS à homossexualidade, ao mesmo tempo em que era crucial unir esforços para lutar contra a crescente epidemia que preocupava cada vez mais (PINHEIRO, 2015).

Nesta mesma perspectiva, principalmente com a descoberta do vírus em $1984^{2}$ e pelos posteriores estudos que comprovam as reais vias de transmissão, se intensifica a ideia de "sexo seguro" com proposições centralizadas no uso da camisinha como fator chave de proteção, principalmente na prática sexual homoafetiva. Segundo Pinheiro (2015), o manual How to have sex in an epidemic, de Berkowitz e Callen (1982), foi uma das principais referências mundiais que trazia, ainda que de forma grosseira e restritiva, um conjunto de intervenções com a utilização da camisinha para a diminuição das chances de contaminação nas relações sexuais entre gays. No entanto, segundo este autor, a camisinha viria a se tornar muito mais um reforço e objeto de reafirmação da identidade homossexual do que uma resposta positiva e coletiva à epidemia em si (PINHEIRO, 2015).

Os anos finais da década de 80 , no Brasil e no mundo, foram marcados por inúmeros acontecimentos com consequências decisivas para o tratamento do HIV no período subsequente. Por exemplo, no Brasil temos a história do cantor Cazuza que, em 1987 foi levado à Boston, onde as pesquisas relacionadas a Aids estavam mais intensas e avançadas, e passou a tomar o AZT (um medicamento inibidor do vírus HIV). Cazuza morreu em julho de 1990; ele foi um dos famosos brasileiros, na história do país, que morreu em decorrência da Aids. Em 1989, já havia mais de 6 mil casos registrados no Brasil de pessoas infectadas com o vírus (BRASIL, 2015). Em relação à assistência, temos o reconhecimento do Estado, através da

${ }^{2} \mathrm{O}$ vírus é isolado pela primeira vez na América Latina apenas em 1987 por pesquisadores da Fundação Oswaldo Cruz (BRASIL, 2015). 
Constituição Federal de 1988, da saúde como um direito de todos e dever do Estado - artigo 196. Esse fato subjaz as ações tomadas nos anos seguintes, como a lei 8080, de 19 de setembro de 1990, que fundamenta as atribuições e funcionamento do Sistema Único de Saúde - SUS, e a Lei Federal 8142, de 28 de dezembro de 1990, que acrescenta a participação da comunidade na gestão do Sistema Único de Saúde, e que trata também sobre as transferências intergovernamentais de recursos financeiros na área da saúde (MOURA, 2019). Esse conjunto de ações representa um divisor de águas na história das políticas de saúde do Brasil, e, consequentemente, para a Aids.

\section{A segunda década: a heterossexualização do HIV/Aids e os novos desafios da epidemia}

Em apenas dois anos, os casos acumulados de Aids no Brasil quase dobraram, chegando a, aproximadamente, 12 mil casos notificados no fim de 1991. A situação se torna cada vez mais preocupante para os que estavam ligados diretamente no combate à doença e para a sociedade de modo geral (BRASIL, 2015; PINHEIRO, 2015).

Parker (2002) afirma que a base para os pesquisadores da sexualidade e HIV (ainda que pelo prisma biomédico), na década de 1980, era o conceito comportamental individualista, que trazia como ponto chave a perspectiva do risco. Tratava-se de um modelo de grupo suscetível, no qual estavam excluídos quaisquer fatores associados e/ou correlatos com o espraiamento da infecção. Já na segunda década da epidemia, os pesquisadores se debruçam sobre os determinantes socioculturais e a identificação dos diversos sentidos que as pessoas atribuem às suas práticas sexuais. Tais concepções passam a ganhar um espaço importante no que tange a compreensão da história da infecção pelo vírus HIV. É neste contexto, no qual os estudiosos e militantes visualizam este cenário multifacetado, que se inicia a utilização do conceito de vulnerabilidade (PARKER, 2002; TERTO Jr. 2002).

O envolvimento das ONGs na luta contra a epidemia de HIV/Aids no Brasil tornou-se referência mundial (SILVA, 2005). Importantes parcerias entre 
o Estado brasileiro e as organizações não governamentais resultaram em um movimento composto por inúmeras ações no âmbito dos direitos humanos e no campo da Saúde Pública com o intuito de assegurar o acesso ao tratamento e a expansão da prevenção no país. Esta interlocução entre o "poder brando" (chamado mundialmente de soft power) e as esferas de poder político/governamental propriamente dito, foi oriundo de diversos grupos de militância. Destaca-se neste contexto o movimento gay, que intencionava a priori a dissociação da ligação ainda presente entre homossexualidade e Aids, mas também o fortalecimento da identidade homossexual e a ferrenha defesa dos direitos destes (SILVA, 2005; PINHEIRO, 2015).

Os anos 90 - período pós-constituição e de implementação do Sistema Único de Saúde, com forte participação da militância nas lutas sociais contra a Aids no Brasil - formavam um cenário relativamente positivo para a criação e consolidação de políticas públicas nacionais no campo da saúde, favorecendo a luta contra a doença e múltiplos apoios a ações e projetos que já vinham sendo conduzidos. A incorporação dos medicamentos "anti-HIV", na tabela SUS, em 1992, e a fabricação, no ano seguinte, do AZT (zidovudina) em território nacional foram passos importantíssimos, porém insuficientes no combate à epidemia. Até o ano de 1995, a assistência medicamentosa no SUS contava com apenas três tipos de medicamentos para tratamento do HIV: AZT, VIdex e dideoxiditina. Contudo, havia inúmeras ações dos gestores públicos, tanto ao nível assistencial quanto preventivo, com um intenso esforço e dedicação, objetivando diminuir o máximo possível, os casos da doença no Brasil (PARKER, 2002; TERTO Jr. 2002).

Em 1996, o Programa Nacional de DST e Aids produz um consenso sobre o uso da terapia antirretroviral e garante o direito ao recebimento gratuito da medicação para os usuários em tratamento. Esse fato representa uma conquista ímpar para o Brasil (Ministério da Saúde) no combate à epidemia. Os esforços para combater a doença na segunda metade da década de 1990 só aumentavam. O ministério da saúde lançou campanhas importantes como "Sem camisinha não tem carnaval" e "A força da mudança - com os jovens em campanha contra a Aids". Em 1999, observava-se 
diversos resultados positivos das ações tomadas ao longo de todo este tempo turbulento: havia uma diversidade de medicamentos contra HIV (aproximadamente uns 15 tipos) e a mortalidade por Aids havia diminuído em $50 \%$, conquistas reconhecidas mundialmente (ABIA, 2013; BRASIL, 2015).

Um marco altamente relevante observado no fim de século XX e que muda completamente o quadro epidemiológico da AIDS no Brasil é a "feminização" da epidemia. Trata-se do aumento da incidência de HIV/Aids em mulheres, perpassada por aspectos sociais, bem como por diversas questões relacionadas a sexualidade e gênero. Inicialmente invisível dentre mulheres ou restrita a profissionais do sexo, a epidemia agora apresentava a proporção de uma mulher para cada dois homens infectados por HIV, de acordo com os casos notificados no país naquele período (PARKER, 2002; BASTOS, 2002; BRASIL, 2015).

O aumento expressivo de casos de HIV/Aids em mulheres na virada do século $X X$ evidenciou o impacto das diferenças sociais e de gênero nas mudanças da epidemia de Aids no Brasil. No início da década 1990, observouse que os casos de HIV em mulheres espalhavam-se de modo progressivo para as diversas camadas sociais da sociedade, atingindo cada vez mais a chamada população geral. Na sequência, nota-se que a população mais pobre passa a ser intensamente atingida, emergindo também o conceito de "pauperização" da epidemia de HIV (BASTOS, 2002; CUNHA, 2012).

O número crescente de casos de HIV em mulheres na década de 1990 possui diversas razões possíveis. Para as mulheres, durante relações sexuais desprotegidas, o risco de contrair HIV é de duas a quatro vezes maior em relação aos homens. Isso ocorre porque, biologicamente, em relações heterossexuais as mulheres ficam mais expostas, devido à maior área de exposição da mucosa vaginal aos fluídos seminais (VARELLA, 2015). Este risco ainda é acrescido quando se considera as dificuldades de negociação com o parceiro em relação ao uso de camisinha, aspecto ainda mais acentuado na ocorrência de relações sexuais não consentidas. De acordo com a UNAids, cerca de $35 \%$ das mulheres de todo o mundo já sofreu violência física ou sexual em algum momento de suas vidas. Em alguns locais 
no mundo, a violência aumenta em 1,5 vezes o risco para mulheres se infectarem com HIV (VILELA; SANEMATSU, 2003; UNAids 2018).

Outra questão fundamental para a compreensão do aumento de casos de HIV em mulheres é a cultura sexual latino-americana centralizada em ideais machistas. Nesse cenário, a infidelidade masculina, por exemplo, é uma questão socialmente aceita, mas que evidentemente torna as mulheres em relações heterossexuais estáveis mais vulneráveis a infecções sexualmente transmissíveis (PARKER, 1997; VARELLA, 2015).

PARKER (1997) traz importantes reflexões sobre a sexualidade no contexto do HIV. O autor traz o machismo como a provável principal característica da cultura sexual na América latina. Segundo o autor, o machismo é um sistema complexo que estabelece uma hierarquia sobre a organização das relações de gênero. Essa hierarquia pressupõe uma relação de poder em que os homens exercem domínio sobre as mulheres. Nesse contexto, cabe ao homem desbravar sua sexualidade, com liberdade de agir e experimentar; já à mulher, cabe o papel passivo, para além de submeter-se ao homem, guardar-se sexualmente e reprimir suas vontades. Certamente, esta é uma imagem polarizada sobre os modos como homens e mulheres se acercam em relação aos modos de viver e construir a sexualidade. Apesar das evidentes gradações entre estes dois polos, parece-nos que a lógica de maior "recato" feminino e maior estímulo à "experimentação" masculina permanece presidindo de forma estrutural a organização social da sexualidade em diversos contextos (RUBIN, 1986; HEILBORN et al., 2006; BARBOSA; KOYAMA, 2008)

O machismo impacta diretamente nas práticas sexuais, organizadas a partir de roteiros que contém normas do que é ou não socialmente aceitável e permitido. Estas normas são fundamentais para a definição e imaginário das práticas sexuais aceitáveis ou desviantes (RUBIN, 1985; PARKER, 1997). É nesse sentido que se criam caminhos alternativos com novas normas ligadas a relações eroticamente satisfatórias, e não com enfoque reprodutivo. As práticas "desviantes", como sexo oral e sexo anal, estão associadas a um risco maior de transmissão pelo HIV. Nesse cenário, há uma maior permissibilidade 
de experimentação sexual para a população masculina do que em relação a feminina.

SANTOS et al 2009 afirmam que os casos de Aids em mulheres refletem quadros sociais desiguais que aumentam a vulnerabilidade feminina à infecção por HIV. Como exemplo disto pode-se apresentar o fato de que as mulheres com HIV no Brasil possuem menor grau de escolaridade do que homens vivendo na mesma situação. Além disso, as altas proporções de mulheres que apresentam a informação de que os parceiros possuem múltiplas parcerias e, que isso as colocam em maior exposição, reforçam a cultura sexual machista, em que para homens alguns comportamentos não são apenas mais frequentes, mas também socialmente aceitos. É ainda mais preocupante esse cenário, quando se pensa que parte significativa dessas mulheres não estão munidas de recursos concretos e/ou simbólicos para romper a relação ou transformar os termos de conduta do parceiro.

Barbosa (1999) é categórica ao afirmar que "a vulnerabilidade feminina ao HIV necessariamente remete às formas como homens e mulheres se relacionam em nossa sociedade, a dinâmica de poder que perpassa tais relações e o imaginário coletivo em relação aos papéis de gênero - que, certamente, constituem importantes variáveis na conformação do perfil da epidemia".

É fato que o HIV, por muitos anos, foi tratado como um problema de saúde unicamente masculino, o que produziu um apagamento tanto dos casos de mulheres com HIV, em menor número inicialmente, quanto do tratamento e modos de (con)viver com a doença. Esse apagamento também impactou no tema das mulheres vivendo com HIV enquanto campo de pesquisa científica, aspecto que pode ser observado na baixa produção e menor interesse de pesquisas acadêmicas sobre a infecção em mulheres, sobretudo nas primeiras décadas da epidemia (VILELA; SANEMATSU, 2003).

De acordo com dados do Boletim Epidemiológico da Aids 1980-2000, entre os anos de 1994 e 1998, houve um aumento de mais de $75 \%$ dos casos de HIV entre mulheres. Entre os heterossexuais, de ambos os sexos, esse aumento foi de 43,5\%. Em 1998, ano com maior número de notificações de 
HIV em mulheres na década de 1990, foram notificados mais de 7 mil casos de HIV no sexo feminino. É importante salientar que parte significativa dessas mulheres encontravam-se em relações estáveis, o que propiciava um cenário de maior sensação de segurança e de não- risco de infectar-se por HIV (VIANNA, 2018).

A ausência de campanhas de prevenção, nos anos iniciais da epidemia do HIV/Aids, para a população heterossexual, especialmente para as mulheres, somada ao fato de que a Aids era tida como um problema de saúde exclusivo dos homossexuais masculinos, criou um cenário favorável para a heterossexualização da epidemia na década de 1990 (VIANNA, 2018). Nesse contexto,

[...] ainda que a incidência no gênero feminino não se torne predominante no quadro geral da doença, seu crescimento desdobra-se em transformações no jogo epidêmico que, entre outras coisas, contribui para o reforço das reivindicações para que a aids seja vista como uma doença de todos (VIANNA, 2018).

Os novos conceitos acerca da população acometida pela epidemia de HIV, e esses "novos vulneráveis", que até então eram considerados protegidos da AIDS, evidencia as potenciais associações dos marcadores sociais da diferença com uma epidemia intensamente relacionada à sexualidade, que por sua vez, é um campo multifacetado e complexo. A epidemia de HIV está associada não somente às diferenças sociais e econômicas no Brasil e no mundo (BASTOS, 2002; PARKER, 2000; BIEHL, 2011). Gênero, raça, sexualidade, geração e classe social são dimensões estruturais que impactam o curso da epidemia de Aids. A feminização da epidemia do HIV, para além de provar que a Aids não era uma questão de saúde restrita aos homens, especialmente os homens gays, traz novas demandas em termos de tratamento e prevenção, seja entre as próprias mulheres, quanto em relação ao nascimento de crianças com HIV (VILELA; SANEMATSU, 2003).

No Brasil, desde a segunda década da epidemia, mais de $80 \%$ dos casos notificados em crianças de até 13 anos é decorrente da transmissão 
vertical (BRASIL, 2018). Em resposta ao crescimento da epidemia na população feminina, em 1995, o Ministério da Saúde criou uma norma específica para a prevenção da transmissão vertical, que foi colocada como prioridade pelo Programa Nacional de DST/Aids. As recomendações dessa norma foram implementadas oficialmente em 1997 com a Portaria Técnica Ministerial no 874/97, com a atualização e inclusão de tais recomendações nos manuais de condutas para o tratamento de adultos e crianças infectadas pelo HIV (BRITO et al. 2006).

Em que pese os avanços do tratamento para as pessoas que vivem com HIV, e a consequente redução da mortalidade pela doença, pode-se considerar essas conquistas como um importante divisor de águas na história da Aids, principalmente na perspectiva da reprodução. Passa-se de um período de intensa mortalidade e extensa ocorrência de transmissão vertical, que gerou uma consequente "epidemia" de órfãos da Aids, para um momento de continuidade da vida, com novas possibilidades e inúmeras discussões políticas em torno dos direitos reprodutivos das mulheres que vivem com HIV (GONÇALVES, 2009; MORELL et al. 2004). O cenário se altera sobremaneira a partir do acesso à TARV e do protocolo ACTG 076. Os resultados do Protocolo 076 do Aids Clinical Trial Group - (PACTG 076) evidenciaram uma redução de $67,5 \%$ na transmissão vertical com o uso da zidovudina (o AZT) durante a gestação, trabalho de parto e parto e pelos recém-nascidos que foram alimentados exclusivamente com fórmula infantil.

As novas tecnologias de tratamento a pessoas vivendo com HIV, como a Terapia antirretroviral combinada, revolucionaram a atenção à saúde das pessoas infectadas com o vírus no Brasil e no mundo. A expectativa de vida de adultos e crianças que vivem com HIV aumentou significativamente, o que delineou um novo cenário, especialmente para as mulheres, que passam a poder engravidar sabendo da possibilidade de uma sobrevida bem maior do que a existente no início da epidemia, e que seus filhos têm baixíssimo risco de nascerem com o vírus desde que elas estejam em tratamento (ROMANELLI et al. 2006). Na ausência da TARV, o risco de transmissão vertical chega a $45 \%$; contudo, caso o protocolo seja cumprido por completo, 
esse risco chega a quase zero (TEIXEIRA et al. 2013). Nesse sentido, podese observar que o Protocolo ACTG 076 somado a terapia antirretroviral combinada, transformaram substancialmente 0 campo dos direitos reprodutivos de mulheres vivendo com HIV/AIDS.

\section{A terceira década: disputas em torno dos insumos de prevenção, diagnóstico e tratamento}

A epidemia na África, até então ignorada pelos países desenvolvidos, é fortemente enfocada durante a $13^{\text {a }}$ Conferência Internacional sobre Aids que ocorre em Durban em 2003. Foram feitas denúncias em meio a relatos que explanavam sobre a grave situação de calamidade no continente. Até aquele momento, a alta mortalidade por Aids na África havia dizimado 17 milhões de pessoas, sendo que, aproximadamente um quinto deste total eram crianças (ABIA, 2013). Além disso, no contexto da década anterior, no auge do processo de feminização do HIV, o número de casos de Aids em mulheres no continente africano chegava a 4 milhões (PAIVA et al. 2002).

Terto Jr. (2002) afirma que a terceira década trazia muitos desafios, apesar das inúmeras conquistas obtidas nos 20 anos anteriores. $O$ quadro epidemiológico apresentava uma porcentagem de $24 \%$ de casos relacionados a transmissão homo- bissexual contra 47\% na década de 1980. Mesmo assim, a Aids ainda era fortemente relacionada aos gays enquanto principais vulneráveis e acometidos pela epidemia. Seguindo este caminho, as políticas de saúde para a população homossexual eram sempre vistas sob o ângulo do HIV. Logo, as ações eram restritas ao combate e prevenção da Aids, supondo que se diminuíssem as taxas de incidência e prevalência do HIV para os homossexuais, consequentemente o grupo tornar-se-ia saudável e a epidemia arrefeceria. As políticas permaneciam carregadas de preconceito: cita-se como exemplo a proibição da doação de sangue por homossexuais no país (ainda vigente), mantendo fortemente presente no contexto nacional o estigma que sustenta a relação Aids-homossexualidade.

Todavia, enquanto na segunda década a mortalidade de homens e mulheres relacionada ao HIV/Aids apresentava um comportamento similar, 
nesta terceira década há um controle da mortalidade masculina, fazendo com que as tendências se tornassem estáveis, principalmente para a faixa etária mais atingida, de 25 a 34 anos de idade. Já para as mulheres, este quadro continua preocupante, com as tendências ainda crescentes, sendo as mais jovens as mais atingidas (PARKER, 2001).

Esta transformação no quadro epidemiológico da epidemia de HIV no Brasil, fortemente observado pelo prisma das tendências de mortalidade (maior para as mulheres, naquele momento), evidencia que não se trata de um fator determinante da vulnerabilidade que compõe um grupo de risco específico, como se pensava inicialmente, associando a doença aos gays. Mas ela revela que indivíduos em contextos diferentes podem apresentar vulnerabilidades que ultrapassam o nível comportamental/individual. Às tais realidades podem se atribuir condicionantes que propiciam as características da epidemia de HIV no país, nunca uni causal, mas sempre pensando em possibilidades e consequências resultantes de um processo multifacetado (ANDERSON, 1996 apud PARKER, 2001).

Anderson (ANDERSON, 1996 apud PARKER, 2001), em sua revisão no ano de 1996, descreve uma questão fundamental para o entendimento do comportamento das doenças infecciosas nas populações. Trata-se da modelagem matemática da dinâmica das epidemias, que sintetiza a forma como os agravos infecciosos atingem os grupos vulneráveis e em que ordem ocorre este processo. Segundo o autor, a doença infecciosa se dá por uma conduta bifásica, a primeira atingindo as pessoas com comportamentos específicos, responsáveis por colocá-los sob potencial risco (como o sexo anal e compartilhamento de agulhas e/ou seringas). A segunda fase deste processo ocorreria de maneira extensa e prolongada, na qual há a "saturação" dos casos para os grupos de risco em especial e passa a atingir outras camadas da população com baixo risco individual, porém de grande magnitude, considerando o alto número de pessoas que compõem estes grupos (ANDERSON, 1996 apud PARKER, 2001).

Os espaços institucionais de debate e discussão da Aids, como conferências internacionais, fóruns latino-americanos e congressos nacionais 
foramextremamente decisivos para o futuro das ações políticas e assistenciais em saúde correlatas a epidemia de HIV a nível mundial. Por exemplo, nestes espaços ocorreram denúncias sobre os altos preços dos antirretrovirais praticados mundialmente, os quais foram diminuídos em até 50\% em 2007. O HVTN (HIV Vacine Trials Network) realizou testes vacinais em diversos países, dentre eles, o Brasil. Em parceria com a África, o Brasil efetuou um investimento de 10 milhões de dólares para a instalação de uma fábrica de antirretrovirais em Moçambique (ABIA, 2013).

A construção da primeira indústria estatal de preservativos no Brasil foi concluída em 2008, o que contribuiu também para o recorde de distribuição de preservativos no país, chegando a 465,2 milhões de camisinhas no ano de 2009. Importante destacarmos que também no ano de 2008 houve a conclusão das pesquisas para o processo nacional da criação de um teste rápido e eficaz para a detecção do vírus HIV. Essa foi uma conquista que resultou na criação de um teste capaz de detectar a presença do vírus no sangue em 15 minutos, custando 2 dólares para a fabricação de cada kit pela Fiocruz. Até então o poder público gastava 5 dólares por cada teste (ABIA, 2013).

No ano de 2002, a UNAIDS (Programa Conjunto das Nações Unidas sobre HIV/Aids) afirmava, em um de seus relatórios, que a Aids mataria aproximadamente 70 milhões de pessoas no mundo nos anos seguintes, a maior parte destes na África, a menos que as nações unissem forças para combater tal realidade (ABIA, 2013). No fim desta década, a perspectiva do ponto de vista individual ou coletivo em relação ao HIV era de controle, se assim fosse possível, mas não de erradicação, o que não difere muito do rumo das diversas doenças transmissíveis no mundo (BASTOS, 2006), apesar do enorme contingente de conquistas científicas e sociais até então obtidos.

\section{chave}

A quarta década: recrudescimento da epidemia e as populações-

A quarta década, ainda em curso, é marcada principalmente por ações governamentais, envolvendo parcerias, no âmbito da prevenção e 
garantia dos direitos sociais das pessoas vivendo com HIV/Aids.

Diversas iniciativas tiveram papel fundamental na conscientização popular no intuito de desconstruir a ideia de grupo de risco enquanto determinante de vulnerabilidade. Alguns exemplos em relação a São Paulo podem ser citados. ${ }^{3}$ A PECAP 2008 (Pesquisa sobre Comportamento, Atitudes e Práticas Relacionadas às DST e Aids da População Brasileira de 15 a 64 anos de idade), lançada no ano de 2010, bem como a preparação de um material educativo sobre identidade e respeito preparados por travestis na campanha de combate ao preconceito nos serviços de saúde e na sociedade, são ações que levam em conta questões sociais, culturais e fortalecem o combate ao estigma da homossexualidade em relação a doença na agenda das políticas de saúde e direitos humanos. As noções de comportamento de risco e de populações-chave ganham destaque neste período, o que exigiu mudanças radicais nos discursos e ações de prevenção (ABIA, 2013; PINHEIRO, 2015).

Diversas estratégias extremamente importantes para o processo de controle da epidemia foram desenvolvidas. Dentre elas, podemos citar a preconização do tratamento precoce enquanto ação de prevenção contra o HIV. Houve a introdução de novos medicamentos potentes, como atazanavir e raltegravir - por meio do estabelecimento de parcerias público-privadas -, e a versão genérica do tenofovir, indicado para Aids e hepatites. Há também uma mudança em termos de indicação quanto ao momento de uso da medicação: esta passa a ser preconizada para todas as fases da doença. Além disso, estimula-se a antecipação do tratamento em parceiros fixos sorodiscordantes e introduz-se a "PEP" (Profilaxia Pós Exposição) na rede assistencial do SUS para prevenção e redução do risco de infecção da doença para pessoas que possam ter entrado em contato recentemente com o vírus (ABIA, 2013; CRT-Aids). Ao protocolo ainda mais recente, acrescenta-se a

\footnotetext{
${ }^{3}$ Atualmente, com a crise política e econômica no Brasil, o país vive um momento em que os direitos sociais estão em xeque, principalmente quando se leva em consideração 0 congelamento dos gastos públicos com ações e políticas de saúde, que estabelece um teto para as despesas do Governo Federal, com cifras corrigidas pela inflação, por até 20 anos.
} 
PrEP (Profilaxia Pré Exposição) também como ferramenta de prevenção. Em 2013, os protocolos de atendimento e tratamento para o HIV/Aids tomam lugar do até então prevalente consenso médico. Neste mesmo ano, anuncia-se a possibilidade da venda em farmácias do teste rápido através do fluído oral, e inicia-se a capacitação das ONGs para aplicação destes testes em populações-chave (ABIA, 2013).

Neste momento, estamos diante de um fenômeno preocupante no que concerne o perfil epidemiológico da Aids no Brasil, a saber, o "rebote da epidemia". Este termo se refere ao cenário atual em que a epidemia voltou a recrudescer, sobretudo entre jovens homossexuais. Neste contexto, podemos argumentar em termos de limites das estratégias de prevenção e controle, principalmente quando relacionadas ao "grupo de risco" delimitado desde os primeiros casos da doença no mundo (PINHEIROS, 2015; ROSENTHAL, 2008).

Devido a tamanha complexidade, há a necessidade de profunda reflexão para compreensão dos fatores relacionados ao quadro em questão. Dois elementos importantes, e relativamente novos, se destacam neste período: as práticas do barebacking e bugchaser. O primeiro refere-se a atividade sexual intencionalmente sem camisinha, a despeito do possível risco de infecção ao manter relações sexuais com pessoas desconhecidas e sem prevenção; neste caso, o que move quem realiza esta prática é o desejo de fazer sexo sem camisinha, ainda que existam riscos (PARKER, 2015). Entretanto, a mídia e as redes sociais vêm alertando para a existência de um grupo de homens portadores do vírus HIV que frequentam saunas e casas de sexo gay com o intuito de infectar propositalmente seus parceiros sexuais, o chamado "clube do carimbo". Diferentemente dos barebackers, os bugchaser (que significa caçador de insetos) são homens HIV negativos que se reúnem em festas para ter práticas sexuais com diversas pessoas desconhecidas mas, entre estas, misturam-se pessoas soropositivas e soronegativas para a prática da popularmente chamada "roleta russa sexual": os soronegativos (bugchasers) vão em busca do parceiro infectado (vitaminado), objetivando 
infectar-se com o vírus. O "ritual" conclui-se no momento do exame de detecção do HIV; se infectado, o "jogo" termina com sucesso, pois o objetivo foi alcançado (SILVA, 2009). Não se trata de refletir sobre estes grupos para novamente definir categorias de bons ou maus comportamentos sexuais e mais uma vez estigmatizar e produzir efeitos ideológicos negativos (PARKER, 2015). Trata-se de um imenso desafio para compreender os múltiplos sentidos e significados dos comportamentos sexuais, que transbordam certa noção hegemônica de cuidado de si (FOUCAULT, 1985).

Há diversos avanços e respostas biomédicas positivas nesta última década, e, considerando as características da epidemia como estando concentrada em populações-chave, segundo os boletins epidemiológicos atuais, as agências internacionais vêm argumentando sobre um possível fim próximo da epidemia de HIV/Aids em diversos lugares no mundo, entre estes - Brasil. Tal êxito se dará através destas novas respostas tecnológicas. Segundo Richard Parker, esta afirmativa de controle/erradicação da AIDS enquanto promessa para um futuro próximo é mais ideológica do que representativa da realidade, principalmente quando consideramos as pessoas vivendo com HIV/Aids. Parker atenta novamente para a ocorrência e espraiamento de um vírus "ideológico", produto de uma terceira epidemia, ou seja, para além da epidemia do vírus HIV, somada aos casos confirmados de AIDS, que seriam as duas primeiras, haveria esta terceira epidemia de significados (PARKER, 2015).

O combate ao HIV se intensifica pelas estratégias de cunho biomédico, sobretudo através da medicalização. $O$ enfoque em mudanças comportamentais, tal como nas décadas anteriores (seja com a sugestão de abstinência sexual para os grupos de risco, ou a utilização da camisinha como fundamental na construção da ideia de sexo seguro) vai cedendo espaço para iniciativas focadas na medicalização dos corpos.

Tomamos de empréstimo o conceito de medicalização da sociedade (CONRAD, 2007) para fazer a seguinte ilação: o autor argumenta que a medicalização da sociedade, fenômeno atual, porém nada recente, é um tipo de estratégia que exprime a intolerância da sociedade aos fracassos e a busca 
continuada por soluções "fáceis". Deste modo, podemos considerar que, em certa medida, a aposta na medicalização e a centralidade da dimensão biológica dos corpos, seja no tratamento precoce quando da descoberta da infecção, ou pelas estratégias de PEP ou PreP, por exemplo, é uma tentativa de vencer simplificadamente os "fracassos" da prevenção, até então focalizada na luta pelas mudanças de comportamento dos indivíduos para diminuição da exposição aos riscos de infecção da doença, em busca do controle da epidemia de HIV/Aids no Brasil. Enfim, estamos diante de mais um cenário complexo e desafiador nesta quarta década da epidemia.

Tais desafios revelam-se ainda mais complexos no âmbito da sexualidade juvenil na atualidade brasileira. Hoje a sexualidade se desdobra diante de uma nova ética, que permite a experimentação e contestação dos binarismos, seja pelo prisma do sexo biológico, da identidade de gênero ou da orientação sexual. Vale, portanto, refletir se uma estratégia de combate à AIDS direcionada a um grupo específico, chamado população-chave, será mesmo capaz de erradicar a epidemia. E mais, tendo em vista as estratégias iniciais também restritas aos chamados grupos com comportamentos de risco, podemos nos perguntar se "elas foram efetivas". O aumento da mortalidade feminina na terceira década nos prova que não (PARKER, 2001).

Podemos relacionar o quadro atual ao que STALL (1994) já apontava que ocorrera com os jovens gays norte-americanos na década de 90: após redução da incidência do HIV e mortalidade, estes retomam padrões comportamentais de práticas sexuais consideradas de risco, tornando-se novamente vulneráveis à infecção pelo HIV. Trata-se de uma espécie de "mistura das temporalidades" ou de um "back to the future", em que aquela chamada segunda fase da epidemia tornaria a incidir sobre determinados grupos populacionais/vulneráveis, a não ser que houvesse estratégias capazes de agir no ponto em comum entre o comportamento das pessoas com alta situação de vulnerabilidade e os de baixo risco populacional (STALL,1994 apud PARKER, 2001). Portanto, sendo o HIV uma doença transmitida por via sexual, é seguro acreditar que uma estratégia específica sobre um determinado grupo, os jovens gays (no caso do Brasil, atualmente) 
enquanto população-chave, considerando o contexto da sexualidade juvenil e das relações de gênero, será capaz de combater ou ao menos manter concentrada uma epidemia que toma diversas direções? Acreditar nesta possibilidade pode representar um equívoco repetidamente realizado, cujas consequências já conhecemos. Novamente, a imagem do "back to the future", tal como difundida pelas telas do cinema, nos parece pertinente para especular se estaríamos diante de um período de re-emergência da epidemia de HIV para diversos grupos populacionais.

Ao longo destas décadas da epidemia de HIV/Aids no Brasil, incontáveis e altamente importantes conquistas ocorreram na intensa luta contra a doença no país. A constituição do SUS e seus princípios norteadores de universalidade, integralidade e equidade, sem dúvida foram aliados incríveis para o avanço das políticas de saúde, seja na assistência (como o caso da gratuidade dos antirretrovirais e aumento da sobrevida), ou na prevenção (como as campanhas e a distribuição gratuita de camisinhas no Brasil). Entretanto, os discursos preventivos centralizados no uso do preservativo desconsideram as diversas realidades que compõem a epidemia do HIV/Aids. Pode-se constatar nesta breve cronologia as multifaces da epidemia e a alta complexidade dos fenômenos intersetoriais pelos quais ela perpassa, bem como os desafios e os impasses para o contínuo combate a ela.

\subsection{Planejamento reprodutivo e Transmissão Vertical do HIV} no contexto da epidemia de Aids

Para a introdução da temática do planejamento reprodutivo, consideramos fundamental iniciar esta discussão pelo dimensionamento do campo teórico-político ao qual pertence esse tema. Nesse sentido, se faz necessário um breve histórico sobre a construção dos direitos reprodutivos no Brasil.

O caminho para a construção dos direitos reprodutivos dentro da 
temática mais ampla dos direitos humanos foi um árduo e longo processo sócio-histórico, repleto de avanços e retrocessos. Inicialmente, ainda diante das discussões da Revolução Francesa, o marquês de Condorcet (17431794) apresenta uma visão otimista em relação a população e o desenvolvimento. O posicionamento otimista de Condorcet, apresentado em 1794, previa uma queda progressiva tanto das taxas de mortalidade como das taxas de natalidade. O crescimento populacional e o socioeconômico apresentariam uma relação harmônica e, portanto, favorável ao desenvolvimento humano (CORRÊA; ALVES; JANUZZI, 2015). Contemporaneamente, Thomas Malthus (1766-1834), um economista e pastor da igreja anglicana, apresenta uma posição oposta sobre o crescimento populacional. De acordo com a teoria pessimista de Malthus, a população cresceria em ordem geométrica, enquanto a produção de alimentos crescia em ordem aritmética, o que significava que faltaria alimentos para a população em algum momento devido ao crescimento demográfico (GENNARI, 1980). Esse debate cruza os séculos e se faz presente em diferentes áreas e documentos ao longo do século XX.

As décadas de 1950 e 1960 foram marcadas, internacionalmente, por discussões em torno da chamada explosão demográfica. Dados estatísticos comprovam que esse período foi de fato, o período em que houve o maior crescimento demográfico da história da humanidade. Sob influência da teoria malthusiana, diversos demógrafos defendiam que o Estado deveria desempenhar ações de controle e redução da fecundidade. Nesse sentido, ações governamentais foram tomadas no cenário internacional, principalmente na década de 1970, com entidades criadas a fim de controlar o crescimento populacional, atuando no financiamento de clínicas de esterilização feminina e distribuição de pílulas contraceptivas. $O$ controle sanitário desses métodos era precário ou inexistente em muitos casos, o que revela que as intervenções, além de restrita a corpos femininos, eram precárias e sem controle de possíveis danos à saúde das mulheres (BRASIL, 2002; FRANZE; BENNEDET; WALL, 2017; CORRÊA; ALVES; JANUZZI, 2015). 
Ao mesmo tempo, os movimentos feministas reivindicavam o acesso aos contraceptivos, tanto para a liberdade feminina, em termos de autocontrole de seus corpos, quanto para a dissociação entre o exercício da sexualidade e a procriação (FRANZE; BENNEDET; WALL, 2017). Foi nesse cenário repleto de embates e sob a influência da teoria neomalthusiana que ocorreram os primeiros eventos internacionais, mais precisamente as conferências de População e Desenvolvimento organizadas pela ONU (CORRÊA; ALVES; JANUZZI, 2015).

A discussão em torno do binômio população e desenvolvimento esteve presente nas diversas conferências que ocorreram na segunda metade do século. Houve cinco conferências internacionais de população: a de Roma, em 1954, com discussões predominantemente com enfoque na teoria neomalthusiana; a de Belgrado, em 1965, na qual países de terceiro mundo que não tinham alinhamento ideológico, se dividiam em três visões: controlismo, natalismo e a visão da população concebida como elemento neutro para o desenvolvimento; Bucareste, em 1974, em que a maior parte dos países de terceiro mundo argumentava em defesa de teses natalistas; México, em 1984, em que retorna as preocupações com o "descontrole populacional" e as posições foram pela defesa da estabilização da população; por último, porém muito representativa, a Conferência do Cairo, em 1994. A Conferência Internacional de População e Desenvolvimento (CIPD) do Cairo levou muitas discussões que haviam ocorrido em outros fóruns internacionais articulados do chamado Ciclo Social da ONU, como é o caso da Conferência de Direitos Humanos de Viena, em 1993 e a Conferência do Meio Ambiente e Desenvolvimento, Rio 1992 (CORRÊA; ALVES; JANUZZI, 2015).

A CIPD do Cairo insere a discussão de gênero no contexto do desenvolvimento populacional. Nela, reconhece-se que a população tem dois sexos, e que os direitos das mulheres deveriam ser respeitados tanto no cenário da vida privada, quanto pelas políticas públicas destinadas a alterar padrões demográficos. Além disso, houve forte presença de movimentos sociais nesta conferência, o que aprofundou tais discussões.

Mundialmente, antes dos acontecimentos que se deram nessas 
últimas conferências, nos anos de 1994 e 1995, havia uma tendência de integrar todo esse emaranhado de questões relativas a vida sexual e reprodutiva, relacionadas principalmente às preocupações com o crescimento populacional, sob o termo mais bem-comportado da saúde reprodutiva. Contudo, de acordo com Correa (1999):

Os documentos internacionais da CIPD e de Pequim legitimaram mais do que apenas o termo "saúde reprodutiva". Estão hoje consagradas as noções de direitos reprodutivos, saúde sexual e conteúdos relativos aos direitos sexuais. Entretanto nos discursos, até então, essas definições - complexas e, porque não dizer, "radicais" estavam como protegidas sob o grande guarda-chuva de saúde reprodutiva. Atualmente é possível explicitar o significado de cada um destes termos. Porém, por efeito da vulgarização e simplificação que costuma ocorrer nessa nova etapa do campo, pode ocorrer que sejam aplicados como termos intercambiáveis. É, portanto, fundamental distinguir suas diferenças e significados (1999, p. 40).

No Brasil, durante a década de 1980, o movimento feminista lutava em defesa da autonomia feminina sobre a reprodução, já utilizando o termo "direitos reprodutivos"4. As mulheres lutavam pela autonomia quanto a decisão sobre o número de filhos, o momento de ter filhos, bem como pelo direito de não os ter. Em resposta à essas reivindicações, em 1983 foi criado no Brasil (e implementado a partir de 1984) o Programa de Assistência Integral à Saúde da Mulher (PAISM), que no ano de 2004 foi reformulado e implementado como Política Nacional de Atenção Integral à Saúde da Mulher (PNAISM). Essa política reafirma o compromisso, dentre outras questões, com ações de saúde que contribuam com a garantia dos DSDR (Direitos Sexuais e Diretos Reprodutivos) e preveem a implantação e implementação da assistência no planejamento para homens, mulheres, adultos e adolescentes, no âmbito da Atenção Integral à saúde, seguindo-se os seguintes princípios:

Ampliar e qualificar a atenção ao planejamento familiar incluindo a assistência à infertilidade; garantir a oferta de métodos

${ }^{4} \mathrm{O}$ termo "direitos reprodutivos" foi criado por feministas norte-americanas com intuito de traduzir melhor pautas no âmbito reprodutivo dentro do campo da saúde da mulher. 
anticoncepcionais para a população em idade reprodutiva; ampliar o acesso das mulheres às informações sobre as opções de métodos anticoncepcionais; estimular a participação e inclusão de homens e adolescentes nas ações de planejamento familiar. (BRASIL, 2011, p. 69)

A partir desse histórico relativo aos direitos reprodutivos no Brasil, pode-se perceber que a atenção à saúde da mulher, até a década de 1970 considerava apenas questões relativas a dimensão da procriação, nesse contexto priorizavam-se cuidados no plano gravídico-puerperal (HEILBORN et al. 2008). E que o final do século $X X$ foi marcado por conquistas, tanto no campo do planejamento familiar e reprodutivo, como na atenção a saúde de pessoas vivendo com HIV.

Ao final da década de 90 , por exemplo, além das importantes mudanças que ocorreram nas estratégias de atenção e cuidado às pessoas vivendo com HIV, como o tratamento antirretroviral, houve intervenções políticas no campo reprodutivo, essenciais para a discussão das escolhas e possibilidades das mulheres, principalmente as mulheres que vivem com HIV, no que tange as possibilidades reprodutivas (BARBOSA, PINHO e CABRAL, 2016). A lei de Planejamento Familiar foi promulgada em 1996, mesmo período em que se implementava a distribuição universal e gratuita dos medicamentos antirretrovirais. Essa nova lei possibilita, pela primeira vez, acesso gratuito a métodos importantes de planejamento reprodutivo, como esterilização masculina e feminina (BRASIL, 1996).

Concomitantemente, o acesso aos antirretrovirais estava sendo implementado de modo universal e gratuito através do SUS, o que representa um marco na história da epidemia, especialmente no contexto da reprodução, pois possibilita que as pessoas que se infectaram pelo vírus possam ter a mesma expectativa de vida de uma pessoa que vive sem o HIV. E mais, essa conquista produziu um novo cenário, em que os sujeitos vivendo com HIV pudessem planejar o curso de suas vidas. Nesse contexto, ter/criar filho(s), com grande probabilidade de nascer sem o vírus, torna-se uma possibilidade real (AGENCIA AIDS, 2010).

Alguns estudos demonstram que a infecção do HIV pode produzir 
transformações na vida das mulheres. O diagnóstico por HIV pode representar um turning point na vida de mulheres diagnosticadas com o vírus, especialmente no que tange ao planejamento reprodutivo (SILVEIRA, 2018). O conceito de turning point é discutido no campo mais amplo dos estudos sobre curso de vida. ABBOTT (2019) faz uma analogia com uma função simples e contínua entre dois pontos e caracteriza o turning point como o ponto em que a inclinação da curva muda de direção. Ou seja, nem todas as mudanças abruptas podem ser consideradas turning points, apenas as que forem seguidas por alterações na direção (ABBOTT, 2019).

A descoberta da infecção pelo HIV e o tratamento antirretroviral podem produzir impactos na dimensão reprodutiva da vida das mulheres, podendo implicar em turning point. Algumas dessas transformações podem ser observadas em termos de decisões reprodutivas, por exemplo, ao ponto em que mulheres após o diagnóstico de HIV desistem de engravidar e/ou recorrem à esterilização (ABBOTT, 2019; TEIXEIRA, 2013). De acordo com

TEIXEIRA et al. (2013), o diagnóstico pelo HIV pode produzir efeitos significativos nas decisões reprodutivas de MVHA. Esse estudo mostra que mulheres americanas diagnosticadas com HIV apresentam menores taxas de

fertilidade e maiores taxas de esterilização do que as mulheres sem o diagnóstico. No caso brasileiro, também se observou diferença nas taxas de esterilização entre mulheres vivendo com HIV e mulheres não vivendo com HIV; para as que vivem com HIV as taxas de esterilização foram maiores do que a encontrada para a população feminina em geral (TEIXEIRA et al. 2013).

A pílula contraceptiva hormonal trouxe transformações para a gestão da dimensão reprodutiva, propiciando para as mulheres maior controle sobre a reprodução. Esse advento tecnológico tornou, ao menos teoricamente, a gravidez como um evento que precisa ser desejável, planejável e/ou previsível (CABRAL, 2011). Todavia, as definições em torno das categorias relativas aos diferentes contextos em que uma gravidez ocorre não é uma tarefa simples e consensual. Os termos sempre trazem alguma parcialidade. A denominação "gravidez desejada", por exemplo, não abrange as múltiplas possibilidades de ocorrência de uma gestação. Com exceção dos casos de aborto, no campo 
da pesquisa sobre contextos gestacionais, especialmente nos casos em que as declarações são feitas após o nascimento da criança, é complexo declarar que a criança não foi desejada. Nesse sentido, pode-se compreender que uma gravidez não desejada por exemplo, pode se tornar um bebê desejado (CABRAL, 2011). Os estudos que investigam o planejamento e/ou o nãoplanejamento de uma gestação precisam atentar-se para este tipo de ponderação, pois:

Entre a situação de uma gravidez deliberadamente planejada, em que há manutenção de relações sexuais sem uso de método contraceptivo, com o objetivo de engravidar, e uma gestação imprevista, que inclui falhas no uso de métodos, há uma gama de nuances que escapam da polaridade acima mencionada e tampouco pode ser pejorativamente qualificado como descuido (CABRAL, 2011).

Herzlich (2004) ressalta que "o grande paradoxo da experiência da doença é que ela é tanto a mais individual quanto a mais social das coisas". Nesse sentido, nota-se que não é uma tarefa fácil dissociar os campos público e privado quando se pensa em processo saúde-doença. Todavia, não se pode esquecer que a doença afeta o corpo, e este pertence em larga medida à esfera privada. Sobretudo, não se pode esquecer que a Aids afeta, concomitantemente, sexualidade, amor e intimidade, que são questões que pertencem em certa medida ao campo individual dos sujeitos (HERZLICH, 2004). Quando diagnosticadas em idade reprodutiva, as mulheres vivendo com HIV enfrentam a decisão entre gerar filhos ou não, o que diz respeito não só a dimensão de seus planos de vida individuais, como também ao contexto de suas parcerias, e seu status perante a sociedade, especialmente devido a valorização da maternidade enquanto papel social e cultural da mulher (TEIXEIRA, 2013).

Dentro do campo mais amplo dos direitos reprodutivos, está a discussão do planejamento reprodutivo. O planejamento reprodutivo é um tema complexo que permeia diversas dimensões da vida das mulheres. $O$ planejamento da gestação é um importante objeto de interesse para pesquisadores e formuladores de políticas da área. No contexto da infecção 
por HIV, essa questão se torna ainda mais complexa. O HIV pode trazer mudanças significativas para a vida sexual e reprodutiva das $\mathrm{PVHA}^{5}$, sobretudo porque a detecção do HIV ocorre muito frequentemente durante 0 período de vida reprodutiva das pessoas (TEIXEIRA, et al. 2013).

O conhecimento em relação aos efeitos da infecção por HIV nas decisões reprodutivas de mulheres ainda é escasso. Em especial porque a epidemia de HIV tem intensa relação com condicionantes culturais e sociais, e nesse sentido seus efeitos dependem do contexto (PILECCO, 2014). COOPER e colaboradores (COOPER et al. 2007 apud PILECCO 2014), em estudo realizado na África do Sul, investigaram os efeitos do diagnóstico por HIV nas intenções reprodutivas de mulheres vivendo com HIV. O estudo identificou que as mulheres que viviam com HIV, mas que não haviam revelado sua condição sorológica, sentiam-se pressionadas a ter filhos, enquanto que dentre as mulheres cuja condição sorológica era revelada, a pressão era contrária, elas sentiam-se pressionadas a não ter filhos (PILECCO, 2014).

Quando se pensa em reprodução no contexto do HIV é imprescindível contextualizar, a priori, os significados sociais relativos à maternidade. De acordo com os dados dos últimos boletins epidemiológicos, a maior parte das mulheres infectadas pelo HIV pertence às camadas mais populares da sociedade. Para esse grupo populacional, a família representa um dos principais valores simbólicos e, portanto, é um elemento crucial na constituição de uma identidade social. Nesse sentido, os ideais de procriação das mulheres, incluindo as que vivem com HIV, são centrados no valor da família (KNAUTH et al. 2002).

Para mulheres vivendo com HIV, as decisões reprodutivas perpassam, além das questões culturais e sociais atreladas aos significados da maternidade, dos papeis sociais da mulher, especialmente no âmbito da conjugalidade e da constituição familiar, pelas questões diretamente ligadas ao tratamento do HIV e suas implicações (TEIXEIRA, 2013). No caso das

5 PVHA: Pessoas Vivendo com HIV/Aids. 
gestantes que vivem com HIV, é fundamental considerar o contexto institucional ao qual elas estão inseridas. Uma vez que, se para a população geral as decisões reprodutivas se dão, majoritariamente, em contextos relacionais no plano das parcerias, os serviços de saúde também deteriam importante peso no processo decisório para as mulheres vivendo com HIV (KNAUTH et al. 2002).

O papel institucional na dimensão da reprodução de mulheres vivendo com HIV é essencial para a compreensão dos efeitos da infecção por HIV no contexto do planejamento reprodutivo. Apesar de a maternidade ter significados sociais que transpassam o fato de viver ou não com HIV/Aids, há profissionais de saúde que, em diversos momentos, se ancoram em questões exclusivamente ligadas a infecção por HIV e seus riscos, ao julgar decisões relativas as decisões reprodutivas de MVHA (OLIVEIRA: FRANÇA JUNIOR, 2003). Nem sempre é facilmente aceito que uma mãe soropositiva exponha uma criança ao risco, ainda que controlado, da transmissão por HIV (OLIVEIRA: FRANÇA JUNIOR, 2003; KNAUTH, 1999).

Apesar dos avanços no campo da prevenção e tratamento do HIV no Brasil, o combate à transmissão vertical ainda representa um desafio para o campo da saúde pública. No país, cerca de $80 \%$ das pessoas vivendo com HIV estão em idade reprodutiva. De acordo com informações do Departamento de Vigilância, Prevenção e Tratamento das ISTs, do HIV/Aids e das Hepatites Virais do Ministério da Saúde, entre os anos de 2008 e 2009, cerca de 6 mil mulheres engravidaram após o diagnóstico de HIV (BRASIL, 2007; 2011).

No Brasil, é frequente o diagnóstico de HIV/Aids durante a gestação das mulheres devido ao conjunto de exames solicitados no pré-natal, sendo o teste anti- HIV um deles. Apesar dessa situação ser um indicativo de que há falhas na detecção precoce do HIV, principalmente para as mulheres, o prénatal acaba sendo um momento chave para os programas de saúde. Trata-se de uma chance crucial de não apenas testar a mulher, mas também de incluir o parceiro, estável ou não, na rede de assistência e cuidado a saúde. Além 
disso, é imprescindível que sejam tomadas todas as ações necessárias dentro das possibilidades, para a prevenção da transmissão vertical do HIV.

Com o intuito de prevenir a transmissão vertical do HIV, as mulheres gestantes portadoras do vírus são orientadas a utilizar anti-retrovirais durante a gestação, no momento do parto, e o bebê também inicia tratamento com uso de ARV logo após o nascimento (GONÇALVES et al. 2009). Esse protocolo tem mantido o risco da transmissão de mãe para filho entre 0 e $2 \%$. Embora tecnicamente existam doenças com maiores riscos que o HIV, como a préeclampsia que pode acarretar em um risco de 4,7\% para a mortalidade fetal, a infecção por HIV é vista, na maioria dos casos, como a doença mais negativa em termos de infecção à criança durante a gestação. Esse aspecto pode estar relacionado tanto ao estigma, que leva à culpabilização da pessoa que vive com HIV, como com a situação de precariedade a que grande parte das mulheres com HIV estão submetidas (GONÇALVES et al. 2009).

No início dos anos 2000, impulsionados pelo cenário que a epidemia de HIV apresentava, internacionalmente, diversos pesquisadores realizaram estudos acerca da reprodução de pessoas vivendo com HIV, e, principalmente a reprodução entre casais sorodisordantes. SEMPRINI e colaboradores (SEMPRINI et al. 1992) discutiam a técnica do washing sperm (em português, lavagem de esperma), realizada em casais heterossexuais que desejam ter um filho. Quando apenas o homem vive com HIV, a lavagem é seguida pela fertilização in-vitro e o seguimento da parceira se dá até o sexto mês após o parto, para verificar se a mesma não havia se infectado.

ENGLERT et al. 2001 (apud GONÇALVES 2009) retratam que, apesar da técnica de lavagem de esperma, e da existência de outras alternativas como a fertilização in-vitro com esperma de um doador, diversos casais vivendo com HIV recorriam ao método da concepção natural. Estava em questão não apena o alto custo da maioria dos métodos citados, mas também o desejo por um filho biológico. Autores como VERNAZZA et al. 2006 passaram a descrever maneiras de reduzir os riscos de contaminação por HIV nesses casos, como: confirmação da fertilidade do casal, supressão da carga viral, relações sexuais desprotegidas restritas ao período fértil da mulher. 
Apesar da quantidade de estudos acerca das diminuições dos riscos da transmissão vertical, além do fato de o planejamento reprodutivo representar um direito humano, independente da condição sorológica dos indivíduos, ainda há controvérsias nesse campo. Em diversos casos, as recomendações sobre as melhores práticas e decisões reprodutivas são dadas por profissionais de saúde, sem considerar os planos de vida e contextos socioculturais das pessoas vivendo com HIV, como se os profissionais de saúde sempre soubessem o que é melhor para a pessoa soropositiva (KNAUTH; BARBOSA; HOPKINS; 2003).

O aumento no número de estudos relativos ao planejamento da gravidez no contexto do HIV são relativamente recentes, e acompanha o aumento da oferta de serviços e possibilidades nesse contexto, como o protocolo ACTG 076 e a TARV. Contudo, ainda é insuficiente a disseminação da informação de que é possível que mulheres com HIV tenham filhos sem o vírus. No ano de 2008, por exemplo, a Agência FIOCRUZ noticiou um caso de uma criança, cuja mãe havia sido infectada por HIV via transmissão vertical no final da década de 1980, que nasceu sem o vírus HIV. A notícia, com muito otimismo tinha por título "Filho de infectada com o HIV nasce sem o vírus". A matéria iniciava com a seguinte informação:

A imprensa noticiou na semana passada o caso da paulista infectada com o HIV pela mãe ao nascer, e uma das primeiras crianças a tomar o coquetel no Brasil, e que agora, aos 20 anos, deu à luz a um bebê sem o vírus. A criança nasceu e não tem 0 vírus da Aids (Agência FIOCRUZ, 2008).

A disseminação de informações e desconstrução de estigmas principalmente por mídias sociais é fundamental para os avanços do enfrentamento da epidemia. Quando se trata do planejamento reprodutivo, essa discussão se torna ainda mais complexa. Esse é um assunto que gera polêmica dentro dos próprios serviços de saúde que, muitas vezes, veem a gravidez no contexto do HIV como um problema do qual devem se indignar. Contudo, o modo como essas informações são repassadas aos usuários(as) dos serviços podem causar diversos efeitos, positivos ou não. A condição de 
"paciente" e lou usuário de um serviço de saúde não exclui dos indivíduos a capacidade de apreender e (re)interpretar informações. Por isso, é importante

para a redução dos riscos de transmissão vertical que os profissionais compartilhem informações corretas e de acessivel compreensão, e

possibilitem uma relação de confiança com os usuários, contribuindo positivamente no processo de tomada decisão (KUROKAWA E SILVA, 2006). KUROKAWA e SILVA (2006) reportam a existência no cotidiano dos serviços de um discurso técnico e pouco aberto por parte dos profissionais de saúde, cujas ações se direcionam exclusivamente ao controle da doença, muitas vezes sem mencionar as possibilidades de impedir novos casos de transmissão vertical. Acabam por esquecer que a chegada do HIV não retira das pessoas as perspectivas e desejos para o futuro, embora haja transformações e riscos. Nesse sentido, a hegemonia do discurso técnico, aliada as ações de controle e a autoridade socialmente atribuída aos profissionais de saúde, criam obstáculos no que tange ao diálogo das questões reprodutivas no âmbito dos serviços de saúde.

Nesse sentido, as informações sobre os riscos de transmissão vertical não devem produzir um cenário de controle e restrições, mas nortear possibilidades de vida de modo a garantir direitos das pessoas vivendo com HIV, contidos antes de tudo na declaração de direitos humanos, como é o caso dos direitos reprodutivos.

No Brasil, é notável que, no campo das políticas públicas em termos de planejamento reprodutivo, houve avanços importantes no âmbito da integralidade da atenção a saúde as pessoas vivendo com HIV. Há elementos fundamentais como o acesso a métodos contraceptivos, TARV, além de técnicas de reprodução assistida, que propiciam um cenário mais seguro, no qual os desejos e projetos de família da pessoa vivendo com HIV são possíveis e, em certa medida, acessíveis (GONÇALVES et al, 2009).

O tratamento e a prevenção do HIV em mulheres em idade reprodutiva são colocados como pontos chave no enfretamento da epidemia pela UNAIDS. Investigar os fatores relacionados ao planejamento da gravidez no contexto do HIV é essencial para a discussão e delineamento de políticas 
públicas que promovam, cada vez mais, possibilidades para uma gestação segura, e, desse modo combater de modo assertivo a ocorrência a transmissão vertical do HIV (TEIXEIRA et al. 2017). 


\section{Objetivos}

\subsection{Objetivo Geral}

Descrever o contexto relativo ao planejamento da primeira gestação das mulheres após o diagnóstico de HIV.

\subsection{Objetivos Específicos}

$\checkmark$ Descrever o perfil das mulheres que foram diagnosticadas com HIV e que tiveram pelo menos uma gestação após o diagnóstico;

$\checkmark$ Dimensionar a proporção de primeira gestação planejada após o diagnóstico do HIV/Aids;

$\checkmark$ Analisar os fatores associados ao planejamento da primeira gestação após o diagnóstico de HIV. 


\section{Aspectos Metodológicos}

\subsection{Desenho do estudo, estratégia amostral e procedimento de campo}

Trata-se de um estudo de corte transversal conduzido no município de São Paulo para comparar duas amostras representativas de mulheres: uma de vivendo com HIV/Aids (MVHA) e outra de mulheres não vivendo com HIV/AIDS (MNVHA), todas matriculadas e usuárias regulares dos serviços públicos de saúde. A pesquisa "GENIH: Gênero e infecção pelo HIV: práticas e decisões relativas à saúde sexual e reprodutiva" foi desenvolvida entre os anos de 2013 e 2014, pelo NEPO/UNICAMP, sob coordenação das pesquisadoras Regina Maria Barbosa e Adriana Pinho, em parceria da FSP/USP (PINHO et al., 2017).

O estudo foi realizado em duas etapas: na etapa 1 foram coletadas as informações das MVHA e na etapa 2, das MNVHA. Para compor a amostra de

MVHA (etapa 1) foram incluídas as 18 unidades públicas de saúde de referência que prestam atendimento às mulheres vivendo com HIV/AIDS no município de São Paulo. Para compor o grupo de MNVHA, foi sorteada uma amostra de 38 unidades básicas de saúde, localizadas nas mesmas coordenadorias de saúde das unidades selecionadas para amostra de MVHA.

O tamanho da amostra foi estimado em 1.000 para cada grupo de mulheres, já considerando o efeito do delineamento por amostragem complexa (deff) igual a 1,6. Com esta amostra almejava-se detectar diferenças estatísticas a um nível de significância ( $\alpha$ ) $5 \%$ e poder do teste $(1-\beta)$ de $80 \%$ entre os grupos nas principais variáveis investigadas, como gravidez não planejada, relato de aborto induzido, histórico de violência física/sexual sofrida e uso corrente de métodoscontraceptivos.

A seleção das mulheres, após o sorteio das unidades de saúde para ambos os grupos, foi realizada de modo sistemático de forma a garantir a representatividade da amostra. As entrevistas, com duração média de 80 minutos, foram realizadas nas dependências das unidades de saúde, antes 
ou após a consulta agendada da usuária, através de um questionário eletrônico e com uso de netbooks, por entrevistadoras treinadas para este fim. O questionário biográfico foi estruturado a fim de se reconstituir as trajetórias afetivo-sexuais, contraceptivas e reprodutivas das mulheres, elegendo alguns eventos marcadores para aprofundamento, e análise de sua inter-relação com o diagnóstico de HIV no caso de MVHA (ANEXO A).

Importante ressaltar que, apesar de se tratar de um estudo transversal, a temporalidade dos eventos de interesse da pesquisa foi detidamente investigada. Em outras palavras, datas e/ou idade em que determinado evento ocorreu foi sistematicamente perguntado para as entrevistadas. Assim, há dados como idade da primeira relação sexual; idade em que ficou sabendo do próprio diagnóstico de HIV; idade em que engravidou pela primeira vez; idade na primeira união, etc.

\subsection{População do estudo}

A amostra do estudo GENIH foi composta por 975 MVHA e 1.003 mulheres da atenção básica (MNVHA). Foi realizado um recorte dessa população a fim de atender aos objetivos propostos, incluindo apenas mulheres com pelo menos uma gestação após o diagnóstico de HIV/Aids, totalizando 308 mulheres.

\subsection{Variáveis do estudo}

O desfecho eleito para esse estudo foi o planejamento da primeira gestação após o diagnóstico de HIV.

Foram selecionadas as seguintes variáveis para proceder às análises propostas neste estudo:

\section{Variável dependente:}

Primeira gestação após o HIV planejada (categorias: $0=$ não; $1=\operatorname{sim}$ ).

\section{Variáveis independentes:}

As variáveis selecionadas foram examinadas segundo cinco dimensões da vida das mulheres, sendo essas: 
1) Perfil Sociodemográfico: Estamos considerando, nessa dimensão, determinados aspectos que dizem respeito à caracterização sociodemográfica das mulheres que, nesse estudo, correspondem aquelas que tiveram ao menos uma gestação após o diagnóstico de HIV. Selecionamos um conjunto de variáveis que podem nos ajudar a dimensionar se, e quais, elementos relativos à caracterização sociodemográfica possuem associação com o planejamento da primeira gestação após o diagnóstico do HIV das MVHA.

Variáveis:

Raça/cor (categorias: preta; branca: parda/outras);

Escolaridade (categorias: médio incompleto e -; médio completo e +); Idade atual (em anos) (categorias: $\leq 24 ; 25 \mathrm{e}+$ )

2) História Reprodutiva: A história reprodutiva pregressa das mulheres pode conter informações relevantes sobre experiências, acontecimentos e/ou aprendizados que podem ser capazes de influenciar nas decisões e escolhas no âmbito reprodutivo, após o diagnóstico por HIV. Ao caracterizar o histórico reprodutivo enquanto uma dimensão de análise específica nesse estudo, busca-se abranger eventos reprodutivos que já ocorreram na vida dessas mulheres com o intuito de obter indícios sobre quais desses eventos presentes nessas histórias, principalmente aqueles que ocorreram antes do diagnóstico do HIV, podem estar associados ao planejamento da primeira gestação após o diagnóstico de mulheres vivendo com HIV/Aids.

Variáveis:

Filho antes (categorias: sim; não);

Aborto provocado antes do HIV (categorias: sim; não);

3) Momento da gravidez: Possivelmente, as questões relacionadas ao momento em que uma gravidez acontece podem revelar informações relevantes para o enquadramento do contexto em que ela ocorre. Tais 
informações são ainda mais importantes quando se pretende encontrar os fatores associados ao planejamento de uma gestação, sobretudo quando se trata da primeira gestação após o diagnóstico de HIV. Consideramos que investigar se existem, e quais são elementos relativos ao momento da gestação que estão associados com o planejamento da mesma é fundamental para dimensionar tanto questões individuais quanto especificidades relacionadas ao papel dos serviços de saúde nesse processo. Além disso, como o planejamento reprodutivo ocorre, na maioria das vezes, no contexto de uma parceria, também selecionamos para a análise desse contexto, variáveis relativas a parceria afetivo-sexual no momento da gestação.

Variáveis:

Parceiro HIV + (categorias: sim; não/não sabe);

Coabitação com parceiro (categorias: sim; não);

Idade (em anos) na gestação (categorias: $\leq 24 ; 25$ a 29; 30 a 34; 35

$\mathrm{e}+$ );

4) História contraceptiva: $O$ uso de métodos contraceptivos, para além de representar uma ferramenta utilizada, na maioria das vezes por escolha e responsabilidade exclusiva das mulheres, com intuito de evitar uma gravidez indesejada, é um elemento complexo e importante que também integra o conjunto de possibilidades e ações no âmbito da saúde pública/coletiva na perspectiva do planejamento reprodutivo.

Variáveis:

Primeiro método contraceptivo na vida (categorias: camisinha masculina; pílula contraceptiva; outro/nenhum);

Já usou pílula do dia seguinte (categorias: sim; não/não sabe o que é);

5) Características do diagnóstico do HIV: a infecção por HIV pode trazer transformações para a vida de alguns sujeitos, especialmente no âmbito da saúde sexual e reprodutiva. Considerando que o foco desse estudo é 
identificar questões associadas ao planejamento da primeira gestação de mulheres após o diagnóstico de HIV, é importante investigar se há informações relativas ao momento do diagnóstico que guardem associações com o desfecho dessa pesquisa.

Variáveis:

Idade (em anos) no diagnóstico (categorias: $\leq 24 ; 25 \mathrm{e}+$ );

Via de infecção (categorias: sexual; outras vias);

\subsection{Análise estatística}

Foram realizados os seguintes procedimentos estatísticos:

a. Análise descritiva para caracterização das mulheres com pelo menos uma gestação após o diagnóstico de HIV;

b. Teste de associação pelo qui-quadrado de Pearson (ou teste exato de Fisher) para as variáveis categóricas, possíveis de estarem associadas (variáveis explicativas) ao desfecho de interesse (planejamento da primeira gestação após o HIV). Foram consideradas estatisticamente significativas as variáveis com $p<0,050$, no entanto, foram selecionadas para serem testadas no modelo de regressão logística múltipla todas as variáveis com $\mathrm{p}<0,200$;

c. Regressão logística múltipla para investigar os fatores independentes associados.

Para a construção do modelo múltiplo foram realizadas análises univariadas (entre a variável dependente com cada uma das variáveis independentes selecionadas pelo teste do qui-quadrado), estabelecendo como critério de seleção $p \leq 0,20$, fundamentado no teste da razão de verossimilhança. Com o objetivo de encontrar o modelo mais ajustado, foi aplicada a metodologia progressiva passo a passo (stepwise forward) incluindo as variáveis por ordem de significância - decrescente (da mais significativa - menor p-valor - para a menos significativa - maior $p$-valor) e excluindo todas aquelas com $p>0,050$ que poderiam impedir $o$ ajuste 
adequado do modelo final, analisando-se as variações dos resultados de odds ratio (OR), intervalo de confiança (IC 95\%) e os níveis de significância dos modelos.

$\mathrm{Na}$ análise múltipla permaneceram apenas as variáveis que apresentaram $p \leq 0,050$ e aquelas que foram consideradas como ajuste, caso pudessem corroborar com o desfecho e melhorar o modelo estatístico final.

As análises estatísticas foram realizadas no software Statistical Package for the Social Sciences (SPSS) versão 20.

\subsection{Considerações éticas}

O estudo GENIH foi conduzido em conformidade com os princípios da Declaração de Helsinque, além de obedecer aos requisitos da resolução 196/96 do Conselho Nacional de Saúde para pesquisas que envolvem seres humanos (BRASIL, 1996). Por contemplar distintas instituições de saúde em diferentes esferas governamentais, o projeto original foi submetido a quatro diferentes comitês de ética em pesquisa, a saber: Comitê de Ética em Pesquisa do CRT-AIDS; Comitê de Ética em Pesquisa do Instituto de Infectologia do Emílio Ribas; Comitê de Ética em Pesquisa da Secretaria Municipal de Saúde de SP; Comitê de Ética em Pesquisa da UNIFESP. Ressalta-se que durante o trabalho de campo da pesquisa GENIH, o Termo de Consentimento Livre e Esclarecido (TCLE) foi apresentado, discutido e assinado por todas as participantes que aceitaram fazer parte do estudo (ANEXO H). Para o tratamento dos dados utilizados foram tomados todos os cuidados necessários para preservação das informações sobre cada participante do estudo GENIH (ANEXOS B, C, D, E, F e G). 


\section{Resultados}

No presente estudo foram analisadas 308 mulheres vivendo com HIV e com pelo menos uma gestação após o diagnóstico. A média de idade dessas mulheres foi de 36,97 , com desvio padrão de 7,52 anos, e mediana de 38 anos. Para a idade no diagnóstico, a média foi de 24,32 anos, com desvio padrão de 6,29 anos, e mediana de 24 anos. A menor parte dessas mulheres declarou-se como preta (15,3\%), e a maioria possuía ensino médio incompleto ou menos $(54,9 \%)$. Além disso, chama a atenção a alta proporção de gravidez não planejada após o diagnóstico de HIV (68,7\%).

Tabela 1 - Distribuição numérica (n) e percentual (\%) da população do estudo segundo raça/cor, escolaridade, idade atual e idade no diagnóstico.

\begin{tabular}{|c|c|c|c|}
\hline Variável & Categoria & $\mathbf{N}$ & $\%$ \\
\hline \multirow[t]{3}{*}{ Raça/cor } & Preta & 47 & $\overline{15,3}$ \\
\hline & Branca & 131 & 42,5 \\
\hline & Parda /outras & 130 & 42,2 \\
\hline \multirow[t]{2}{*}{ Escolaridade } & Médio completo e + & 139 & 45,1 \\
\hline & Médio incompleto e - & 169 & 54,9 \\
\hline \multirow[t]{2}{*}{ Idade atual (em anos) } & $\leq 24$ & 27 & 8,8 \\
\hline & $25 e+$ & 281 & 91,2 \\
\hline \multirow[t]{2}{*}{ Idade no diagnóstico (em anos) } & $\leq 24$ & 154 & 51,3 \\
\hline & $25 e+$ & 146 & 48,7 \\
\hline \multirow[t]{2}{*}{$1^{a}$ gravidez após o diagn. planejada } & Não & 211 & 68,7 \\
\hline & Sim & 96 & 31,3 \\
\hline Total de participantes & & 308 & 100 \\
\hline
\end{tabular}

Fonte: Estudo GENIH, Município de São Paulo, Brasil, 2013-14. 


\subsection{Análise bivariada}

A tabela 2 apresenta os resultados para o teste do qui-quadrado, realizado para testar a associação estatística entre as variáveis independentes eleitas para o estudo e o desfecho: planejamento da primeira gravidez após o diagnóstico.

No conjunto denominado de dimensão sociodemográfica, nenhuma das variáveis (idade atual; raça/cor; escolaridade) apresentou associação estatisticamente significativa com o desfecho. Contudo, a variável escolaridade foi selecionada para ser testada no modelo de regressão logística, por apresentar $p<0,200$.

$\mathrm{Na}$ dimensão da história reprodutiva das mulheres, nota-se que houve associação estatisticamente significativa apenas para a variável aborto provocado antes do HIV, em que mulheres que declararam que nunca tiveram um aborto provocado antes do diagnóstico de HIV possuíam maior proporção de planejamento da gravidez $(32,7 \%)$ quando comparadas às mulheres que declararam que já tiveram pelo menos um aborto provocado antes do diagnóstico $(13,6 \%)(p=0,023)$. A variável filho antes também apresentou associação estatisticamente significativa com o desfecho; com $p=0,030$, portanto, foi selecionada para o teste no modelo de regressão logística múltipla.

Para a dimensão do momento da primeira gravidez após o diagnóstico de HIV, a variável coabitação com o parceiro demonstrou associação altamente significativa em relação ao desfecho. Nesse caso, mulheres que moravam com o parceiro no momento da gravidez apresentaram maior proporção de gravidez planejada $(36,6 \%)$, em relação as mulheres que não moravam com o parceiro $(9,2 \%),(p<0,001)$. A variável parceiro HIV+ não apresentou significância estatística na associação com 0 desfecho. Entretanto, por apresentar p-valor menor que 0,200 , ela foi selecionada para ser testada no modelo de regressão logística múltipla.

Quanto a história contraceptiva das mulheres, não houve associação estatisticamente significativa entre nenhuma das variáveis atinentes a esta dimensão (primeiro método contraceptivo na vida; já usou pílula do dia 
seguinte) com o desfecho gravidez planejada após o diagnóstico.

Em relação a dimensão das características do diagnóstico do HIV, não houve associação estatisticamente significativa para nenhuma das variáveis selecionadas, sendo elas: idade no diagnóstico; via de infecção. Contudo a variável idade no diagnóstico foi selecionada para ser testada no modelo de regressão logística, uma vez que apresentou resultado de $p=0,066$ pelo teste do qui-quadrado de Pearson. 
Tabela 2 - Resultados do teste de associação pelo qui-quadrado das variáveis independentes, em relação ao desfecho gravidez planejada.

\begin{tabular}{|c|c|c|c|c|}
\hline \multirow[b]{2}{*}{ Variável } & \multirow[b]{2}{*}{ Categoria } & \multicolumn{2}{|c|}{ Gravidez planejada } & \multirow[b]{2}{*}{ P-valor* } \\
\hline & & $\frac{\text { Não }}{\mathrm{n}(\%)}$ & $\frac{\operatorname{Sim}}{n(\%)}$ & \\
\hline $\begin{array}{l}\text { Total } \\
\text { Variáveis Sociodemográficas }\end{array}$ & & $211(68,7)$ & $96(31,3)$ & \\
\hline Raça/cor & $\begin{array}{l}\text { Preta } \\
\text { Branca } \\
\text { Parda /outras }\end{array}$ & $\begin{array}{l}30(63,4) \\
90(69,1) \\
91(71,6)\end{array}$ & $\begin{array}{l}17(36,6) \\
41(30,9) \\
38(28,4)\end{array}$ & 0,594 \\
\hline Escolaridade & $\begin{array}{l}\text { Médio completo e + } \\
\text { Médio incompleto e } \\
\text { - }\end{array}$ & $\begin{array}{l}90(64,6 \\
121(73,2)\end{array}$ & $\begin{array}{l}49(35,4) \\
47(26,8)\end{array}$ & 0,117 \\
\hline Idade atual (em anos) & $\begin{array}{l}\leq 24 \\
25 e+\end{array}$ & $\begin{array}{l}17(59,5) \\
194(70,2)\end{array}$ & $\begin{array}{l}10(40,5) \\
86(29,8\end{array}$ & 0,266 \\
\hline \multicolumn{5}{|l|}{ História Reprodutiva } \\
\hline Filho antes & $\begin{array}{l}\text { Não } \\
\text { Sim }\end{array}$ & $\begin{array}{l}86(62,8) \\
125(74,5)\end{array}$ & $\begin{array}{l}51(37,2) \\
45(25,5)\end{array}$ & 0,030 \\
\hline Aborto provocado antes do HIV & $\begin{array}{l}\text { Não } \\
\text { Sim }\end{array}$ & $\begin{array}{l}186(67,3) \\
25(86,4)\end{array}$ & $\begin{array}{l}91(32,7) \\
5(13,6)\end{array}$ & 0,023 \\
\hline \multicolumn{5}{|l|}{$\begin{array}{l}\text { Momento da } 1^{\text {a }} \text { gestação após o } \\
\text { diag. de HIV }\end{array}$} \\
\hline Parceiro HIV + & $\begin{array}{l}\text { Não ou não sabe } \\
\text { Sim }\end{array}$ & $\begin{array}{r}155(72,7) \\
55 \\
(61,2)\end{array}$ & $\begin{array}{r}59(27,3) \\
37 \\
(38,8)\end{array}$ & 0,052 \\
\hline Cohabitação com parceiro & $\begin{array}{l}\text { Não } \\
\text { Sim }\end{array}$ & $\begin{array}{l}61(90,8) \\
150(63,4)\end{array}$ & $\begin{array}{l}6(9,2) \\
90(36,6)\end{array}$ & $<0,001$ \\
\hline Idade (em anos) na gestação & $\begin{array}{l}<24 \\
25 \text { a } 29 \\
30 \text { a } 34 \\
35 e+\end{array}$ & $\begin{array}{l}58(66,9) \\
57(68,5) \\
40(64,3) \\
53(75,7)\end{array}$ & $\begin{array}{l}26(33,1) \\
29(31,5) \\
22(35,7) \\
19(24,3)\end{array}$ & 0,533 \\
\hline $\begin{array}{l}\text { Tempo entre o dagnóstico e a } \\
\text { gestação (em anos) }\end{array}$ & $\begin{array}{l}\leq 5 \\
6 \text { ou }+\end{array}$ & $\begin{array}{l}138(68,1) \\
73(71,5)\end{array}$ & $\begin{array}{l}65(31,9) \\
31(28,5)\end{array}$ & 0,554 \\
\hline
\end{tabular}


conclusão

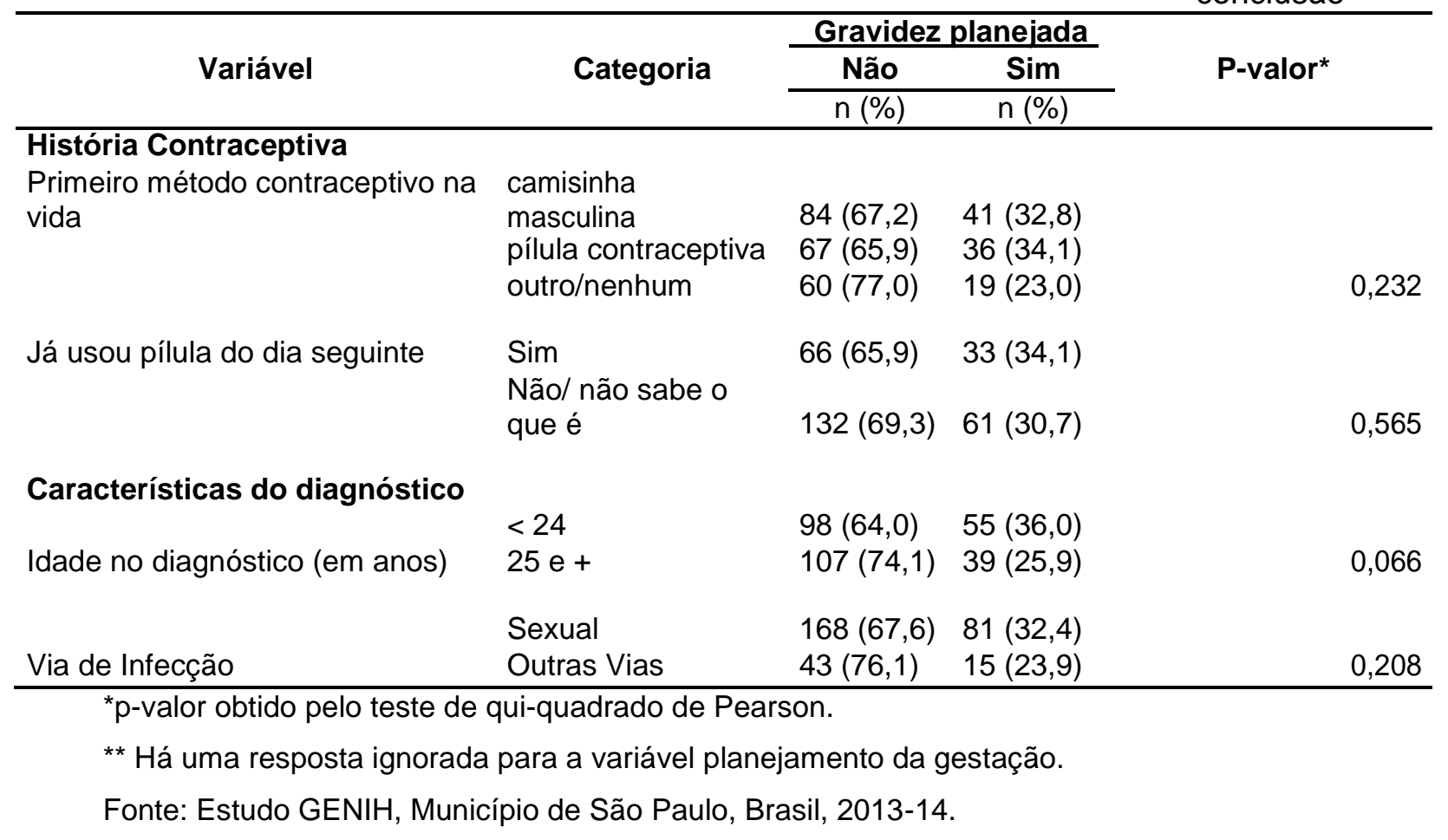




\subsection{Modelo de regressão logística univariada}

Foram selecionadas para o modelo de regressão logística as variáveis que apresentaram $p$-valor menor que 0,200 através do teste estatístico de

associação pelo Qui-quadrado de Pearson. Nessa etapa do estudo foi realizada a regressão logística univariada, a fim de visualizar a interferência individual de cada uma das variáveis selecionadas no desfecho de interesse.

A tabela 3 apresenta os resultados da análise univariada. Nota-se que 2 das 6 variáveis selecionadas para exame nas dimensões anteriormente tratadas apresentaram significância estatística $(p<0,050)$.

Para a variável coabitação com parceiro, observa-se que mulheres que responderam positivamente a essa questão, ou seja, moravam com o parceiro, houve uma chance aumentada em 4,69 para o planejamento da gravidez, quando relacionadas às mulheres que não moravam com parceiro $(\mathrm{p}<0,001)$. No caso da variável aborto provocado antes do HIV, percebe-se que para mulheres que declararam que nunca provocaram um aborto antes do diagnóstico do HIV, há uma chance aumentada em 2,79 de terem planejado a primeira gestação após o diagnóstico, quando relacionadas às mulheres que já haviam tido pelo menos um aborto provocado antes do diagnóstico $(p=0,001)$. Já para a variável filho antes, nota-se que mulheres com filhos antes da primeira gravidez após o diagnóstico de HIV, há uma chance aumentada em 0,73 para o planejamento da gravidez, quando relacionadas as mulheres que não tinham filho $(p=0,031)$.

As demais variáveis (parceiro HIV+; idade no diagnóstico (em anos); filho antes do HIV; escolaridade) não apresentaram significância estatística quando testadas isoladamente com o desfecho de interesse (gravidez planejada). 
Tabela 3- Resultados de ODDs Ratio bruta, obtidos pela regressão logística univariada.

\begin{tabular}{|c|c|c|c|c|c|}
\hline \multirow{2}{*}{$\begin{array}{c}\text { Variáveis } \\
\text { independentes }\end{array}$} & \multirow{2}{*}{ Categorias } & \multirow{2}{*}{$\mathrm{OR}^{*}$} & \multicolumn{2}{|c|}{ TC $95 \%$} & \multirow[b]{2}{*}{ P-valor } \\
\hline & & & Inferior & Superior & \\
\hline \multirow{2}{*}{$\begin{array}{l}\text { Coabitação com o } \\
\text { parceiro }\end{array}$} & Não & 1 & & & \\
\hline & Sim & 5,69 & 2,32 & 13,95 & $<0,001$ \\
\hline \multirow{3}{*}{$\begin{array}{l}\text { Aborto provocado } \\
\text { antes do HIV }\end{array}$} & Sim & 1 & & & \\
\hline & Não & 3,79 & 1,86 & 7,75 & $<0,001$ \\
\hline & Não & 1 & & & \\
\hline Parceiro HIV + & $\operatorname{Sim}$ & 1,69 & 0,99 & 2,88 & 0,053 \\
\hline \multirow{3}{*}{$\begin{array}{l}\text { Idade no } \\
\text { diagnóstico (em } \\
\text { anos) }\end{array}$} & $25 e+$ & 1 & & & \\
\hline & $\leq 24$ & 1,61 & 0,97 & 2,69 & 0,067 \\
\hline & Não & 1 & & & \\
\hline \multirow[t]{2}{*}{ Filho antes } & Sim & 1,73 & 1,05 & 2,84 & 0,031 \\
\hline & Médio completo e - & 1 & & & \\
\hline Escolaridade & Médio incompleto e + & 1,49 & 0,9 & 2,46 & 0,118 \\
\hline
\end{tabular}

Fonte: Estudo GENIH, Município de São Paulo, Brasil, 2013-14. 


\section{3 . Modelo de regressão logística múltipla}

As variáveis selecionadas para o modelo de regressão logística múltipla foram inseridas uma a uma por ordem decrescente de significância estatística, permanecendo no modelo final apenas as que apresentaram significância estatística, ou que por ventura ajustaram o modelo.

De acordo com o resultado do modelo final da regressão logística binária múltipla, os fatores associados ao planejamento da primeira gravidez após o diagnóstico são (Tabela 4):

Coabitação com parceiro: Mulheres que declararam morar com parceiro no período em que ocorreu a primeira gestação após o diagnóstico de HIV possuem chance aumentada em 4,69 vezes para o planejamento da gestação, quando relacionadas às mulheres que não moravam com parceiro. (I.C 95\%: 2,24; 14,84);

Aborto provocado antes do HIV: Mulheres que declararam que não tiveram nenhum aborto provocado antes do HIV apresentaram chance de planejar a gestação igual a 3,79 vezes a chance de mulheres que declararam que tiveram pelo menos um aborto provocado antes do diagnóstico de HIV (I.C 95\%: 1,$04 ; 8,08)$;

Filho antes: De acordo com o resultado do modelo de regressão, mulheres que já tinham filho antes do diagnóstico de HIV possuíam chance acrescida em 0,73 para o planejamento da primeira gravidez após o diagnóstico em relação às mulheres que não tinham filho antes do diagnóstico (I.C 95\%: 1,08; $3,31)$.

O modelo foi ajustado pelas variáveis: escolaridade, raça/cor parceiro HIV+, e tempo (em anos) entre o diagnóstico e a gestação. 
Tabela 4 - Resultadas de Odds Ratio bruta e ajustada, obtidos pelo modelo de regressão logística múltipla.

\begin{tabular}{|c|c|c|c|c|c|c|}
\hline \multirow{2}{*}{$\begin{array}{c}\text { Variáveis } \\
\text { independentes }\end{array}$} & \multirow{2}{*}{ Categorias } & \multirow{2}{*}{ OR bruta } & \multirow{2}{*}{$\begin{array}{c}\text { OR } \\
\text { ajustada* }\end{array}$} & \multicolumn{2}{|c|}{ IC95\% } & \multirow{2}{*}{ P-valor } \\
\hline & & & & Inferior & Superior & \\
\hline \multirow[t]{2}{*}{$\begin{array}{l}\text { Coabitação com o } \\
\text { parceiro }\end{array}$} & Não & 1 & 1 & & & \\
\hline & Sim & 5,69 & 5,77 & 2,24 & 14,84 & $<0,001$ \\
\hline \multirow{2}{*}{$\begin{array}{l}\text { Aborto provocado } \\
\text { antes do HIV }\end{array}$} & Sim & 1 & 1 & & & \\
\hline & Não & 3,79 & 2,89 & 1,04 & 8,08 & 0,042 \\
\hline \multirow[t]{2}{*}{ Filho antes } & Não & 1 & 1 & & & \\
\hline & Sim & 1,73 & 1,89 & 1,08 & 3,31 & 0,027 \\
\hline
\end{tabular}

*Modelo ajustado por escolaridade; raça/cor parceiro HIV+ e tempo (em anos) entre 0 diagnóstico e a gestação.

Fonte: Estudo GENIH, Município de São Paulo, Brasil, 2013-14. 


\section{Discussão}

De acordo com os dados do presente estudo, uma significativa parcela das mulheres declarou-se como branca $(42,5 \%)$ e mais da metade da amostra possuía baixo nível escolar. Grande parte das entrevistadas (mais de 90\%) possuía mais de 25 anos no momento da entrevista, sendo a média da idade atual igual a 36,97 anos. Mais da metade da amostra $(51,3 \%)$ foi diagnosticada pelo HIV até os 24 anos de idade, com média de 24,32 anos.

Um estudo brasileiro de delineamento transversal, publicado no ano de 2011, encontrou características semelhantes em termos do perfil das mulheres portadoras do vírus HIV (FELIX; CEOLIM; 2011). De acordo com os resultados do estudo referido, das 60 mulheres entrevistadas $66,7 \%$ declararam-se como brancas, a média de idade das mulheres era de 39,8 anos; além disso, cerca de $48 \%$ das mulheres possuíam baixo nível de escolaridade, até ensino fundamental incompleto (FELIX; CEOLIM, 2011). A média de tempo em que as mulheres viviam com HIV era de 9,4 anos.

Em relação a raça/cor das mulheres, é importante salientar que na terceira década da epidemia de HIV, havia suspeitas de que a infecção pelo vírus estaria relacionada com a população negra. Contudo, FRY et al. 2006, em um estudo que analisou os bancos de dados de notificação de HIV/Aids no país, verificaram que os dados disponíveis eram insuficientes para determinar a veracidade dessa relação.

Quando relacionamos a idade das mulheres com a idade no diagnóstico, nota-se que se a média de idade no momento da entrevista (2013/2014) foi de pouco mais de 36 anos, e a média do diagnóstico de cerca de 24 anos, ou seja, quase uma década de convivência sabidamente com o vírus. O presente estudo, bem como o de FELIX e CEOLIM (2011) apontam que o diagnóstico dessas mulheres coincide com o período em que houve a feminização da epidemia de HIV no país, entre o fim da década de 1990 e início dos anos 2000.

Considerando a escolaridade como uma proxy de classe social, e partindo da perspectiva das discussões relativas ao perfil das mulheres vivendo com HIV/Aids no Brasil, os dados descritos neste estudo vão ao 
encontro do que está descrito na literatura, ou seja, que a epidemia de HIV na população feminina atinge, em maior proporção, as camadas mais pobres da sociedade, como também a população menos escolarizada (FELIX; CEOLIM, 2011; FRY et al. 2006; PARKER; GALVÃO, 1996; PARKER; BASTOS, 2001). Um ponto fundamental e necessário de salientar é a alta proporção de ocorrência de gestações imprevistas (ou não planejadas) no âmbito deste estudo. Poder-se-ia supor, a partir de um de um certo senso comum, que mulheres infectadas pelo HIV tenderiam a um maior planejamento reprodutivo tendo em vista a necessidade teórica de utilização do preservativo em todas as relações sexuais e um esforço de impedir a transmissão vertical em caso de gestação. Todavia, a infecção pelo vírus parece não ser condição suficiente para alterar todo um padrão social-cultural de manejo da vida contraceptiva, aspecto que não se reduz à uma dimensão lógica e/ou sanitária (CABRAL, 2017).

A proporção de gestações imprevistas no contexto brasileiro, por exemplo, ultrapassa os $50 \%$, segundo estudo realizado por Leal \& Gama, $2011 .{ }^{6}$ No caso das mulheres do presente estudo, o percentual de gravidez imprevista foi ainda mais elevado. Em relação a distribuição das mulheres quanto ao desfecho de interesse desse estudo "primeira gravidez após o diagnóstico de HIV foi planejada", chama a atenção a proporção de mulheres que declaram não ter planejado a gestação: $68,7 \%$ não planejou a primeira gravidez após o diagnóstico de HIV. Essa proporção de não-planejamento da gravidez, por si só, já é um demonstrativo de que o cenário do planejamento reprodutivo de mulheres vivendo com HIV ainda é repleto de complexidades, e, ainda possui lacunas consideráveis.

Se considerarmos que a média mundial de gestação imprevista é de $40 \%$, uma questão que se pode salientar é que, se há um problema acerca da atenção à saúde da mulher no que tange planejamento reprodutivo no país,

\footnotetext{
${ }^{6}$ A pesquisa "Nascer no Brasil: Inquérito Nacional sobre parto e nascimento", coordenada pela Fundação Oswaldo Cruz, entrevistou 23.894 mulheres de todo o país, e, foi a primeira pesquisa a proporcionar um panorama situacional em nível nacional em termos de atenção ao parto e nascimento no Brasil. De acordo com resultados dessa pesquisa, a proporção de gravidez não planejada na população geral é de cerca de 55\% (LEAL; GAMA; 2011).
} 
esse problema se torna ainda maior no contexto do HIV/Aids (PASSARINHO; FRANCO; 2018). Todavia, a possibilidade de engravidamento no contexto do HIV e a manutenção da gestação pode ter relação com algumas questões fundamentais, tais como: a) o tratamento antirretroviral tem garantido uma expectativa de vida similar à da população geral para pessoas vivendo com HIV, ou seja, a gestação não acarretará na "produção de uma criança órfã"; b) o tratamento antirretroviral, quando realizado dentro do protocolo preconizado, diminui o risco a quase zero para a transmissão vertical do vírus HIV, portanto as mulheres não estariam gerando uma criança infectada (GONÇALVES et al, 2009). Nesse caso, a possibilidade de ter um filho não é mais uma questão da qual as mulheres deveriam evitar a qualquer custo, como parece ter sido no início da epidemia, em que grande parte das mulheres diagnosticadas com HIV, ao pensar em ter filhos, passavam por momentos de "dúvidas, incertezas e desespero" (AGENCIA AIDS, 2018).

Um estudo realizado no município de Santo André - (SP) realizou um inquérito domiciliar com vistas a identificar fatores associados ao risco e ocorrência de gravidez não planejada, aborto e uso de contracepção de emergência em mulheres vivendo com HIV. Esse estudo identificou associação entre relatos de falhas mecânicas no uso de preservativos masculinos e gravidez não planejada. Os resultados demonstraram que $40 \%$ das mulheres que tiveram gravidez não planejada associaram esse evento a falhas mecânicas na utilização do preservativo masculino (FIGUEIREDO, 2010). Tendo em vista a alta proporção de não planejamento da gestação encontrada no presente estudo, caberia investigar a fundo se essa seria uma das razões que integram essa alta exposição dessas mulheres a gestações não planejadas, uma vez que o preservativo masculino ocupa um lugar relevante nas recomendações dos serviços de saúde (em termos de contracepção) direcionadas a pessoas vivendo com HIV (FEBRASGO, 2018). Uma consulta realizada no ano de 2006, que foi fruto de uma encomenda da UNFPA - Fundo de População das Nações Unidas, buscou identificar as relações entre saúde reprodutiva e HIV/Aids. Avaliou-se a efetividade de alguns elementos que compõem as diversas estratégias de 
prevenção da transmissão vertical no cenário mundial. O estudo verificou que na África subsaariana serviços de saúde que enfocavam em estratégias biomédicas, como o uso de TARV, possuíam menos efetividade na prevenção de gravidez imprevista e na diminuição das taxas de transmissão vertical. Por outro lado, serviços compostos por estratégias de saúde voltadas ao planejamento familiar eram mais efetivos quanto a prevenção de gravidez imprevista, bem como na diminuição das taxas de transmissão vertical (WHO, 2006). Apesar da efetividade e baixo custo dos serviços de planejamento familiar, comprovados em diversos estudos realizados na África Subsaariana (WILCHER, CATES Jr, GRAGSON, 2012), o planejamento familiar e o enfrentamento ao HIV deveriam ser aliados naturais. Contudo, estas duas dimensões nem sempre aparecem interligadas em diversos lugares do mundo.

Considerando os resultados do estudo citado acima (sobre a efetividade de serviços de saúde, que possuíam atenção voltada ao planejamento familiar com vistas a diminuição nas taxas de transmissão vertical do HIV) e considerando os resultados encontrados no presente estudo, sobre a alta proporção de não planejamento da gravidez em MVHA inseridas em serviços especializados de saúde, vale uma reflexão acerca das atuais estratégias de enfrentamento a epidemia de HIV no país. Deve-se questionar se a tendência atual no contexto brasileiro de enfocar nas estratégias biomédicas, no que tange ao conjunto de ações de combate a epidemia de HIV/Aids, é suficiente para dar conta de uma epidemia que é permeada por questões comportamentais (FERRAZ; PAIVA, 2015). Nesse sentido, pode-se também questionar se no campo das decisões reprodutivas, precisamente o planejamento da gravidez, o delineamento das ações nos serviços de saúde que atendem as mulheres vivendo com HIV têm sido suficientes para dar conta da demanda complexa que envolve o planejamento reprodutivo. A alta proporção de gravidez não planejada, tal como apontada pelo nosso estudo, leva a crer que as estratégias de saúde nesse plano têm sido insuficientes.

Deve-se salientar que esperávamos encontrar um resultado diferente 
do que está descrito neste estudo em relação ao planejamento da primeira gestação após o diagnóstico do HIV. Primeiro porque o planejamento reprodutivo é essencial para a diminuição das taxas de transmissão vertical no país e, segundo porque as mulheres que vivem com HIV estão inseridas em serviços de saúde especializados, e suas decisões reprodutivas, ao menos teoricamente, sofreriam maiores intervenções institucionais (KNAUTH; BARBOSA; HOPKINS; 2003), quer dizer, estariam mais fortemente subordinadas à lógica sanitária da prevenção do HIV (a qual implica, necessariamente, a dimensão de controle e planejamento).

\section{Fatores associados ao planejamento da primeira gestação após o diagnóstico}

De acordo com os resultados desse estudo, os fatores associados ao planejamento da primeira gestação após o diagnóstico de mulheres vivendo com HIV são: coabitação com parceiro; aborto provocado antes do HIV (ausência desse evento, no caso); filho antes do HIV. Assim, temos características que compõem um perfil favorável ao planejamento da gestação de mulheres que vivem com HIV: a mulher que vive com um parceiro, que nunca provocou um aborto e que já tinha pelo menos um filho antes do diagnóstico.

Embora as políticas de saúde possuam objetivos e ações bem definidas, é no plano relacional que as decisões relativas ao planejamento reprodutivo ocorrem de fato (KNAUTH et al. 2002). Assim, não nos parece que tenha sido fortuito encontrar uma forte associação estatisticamente entre o planejamento da gravidez e a coabitação com parceiro em nosso estudo. Tal resultado nos mostra que as mulheres que moravam com parceiro possuíam mais de cinco vezes a chance de planejar a gestação em relação às mulheres que não moravam com o parceiro.

Uma questão essencial para essa discussão é o significado de um filho no contexto da conjugalidade. $\mathrm{O}$ casamento monogâmico entre homens e mulheres configura uma das mais valorizadas instituições da sociedade 
ocidental, em que os papéis de homens e mulheres nessa instituição, mais do que garantir uma satisfação pessoal, são estabelecidos para dar respostas a expectativas sociais (BERTAGNOLI; FIGUEIREDO; 2017). Nesse contexto, uma das grandes expectativas sociais, direcionada em especial para as mulheres, é a expectativa da maternidade. Culturalmente, o engravidamento das mulheres é um processo natural que decorre do casamento e, inclusive, é um evento socialmente aguardado após o casamento. Em diversos casos, percebe-se que o que está em jogo não é o desejo da mulher, mas a obrigatoriedade socialmente colocada à mulher, de que ela dê filhos ao parceiro com quem se relaciona (BERTAGNOLI; FIGUEIREDO; 2017).

Outra questão importante é o fato de que a chegada de um filho, geralmente, não é mudança simples na vida de um casal e, principalmente,

na vida de uma mulher. Ter um filho significa, em muitos casos, ter a vida transformada em diversos aspectos: emocional, social e economicamente. Nessa perspectiva, nota-se que um dos pilares fundamentais para o planejamento de uma gestação é que a mulher tenha uma rede apoio consolidada, que inclui ter alguém que possa ajudá-la após o nascimento da criança (como o apoio familiar), ter uma renda que seja suficiente para o sustento familiar, ou seja, condições socialmente tidas como importantes para constituição de uma prole (REPOPORT: PICCININI, 2006). Portanto, há elementos distintos, porém nada opostos ou excludentes, que podem estar relacionados a alta associação entre coabitação e planejamento da gravidez.

O primeiro é o que diz respeito ao papel social relativo à maternidade e a força que esse significado ganha no contexto conjugal, ou seja, as mulheres que coabitavam com parceiro, poderiam estar em uma situação na qual desejavam e/ou precisavam corresponder a uma expectativa social, além da vontade do parceiro é claro, e, portanto, ter um filho significaria corresponder tais expectativas. Como exemplo desse tipo de cenário, podese citar o estudo qualitativo realizado no interior do estado de São Paulo por BERTAGNOLI e FIGUEIREDO (2017) que contou com extensos relatos de mulheres gestantes vivendo com HIV. O estudo também descreveu um contexto de engravidamento após diagnóstico do HIV, em que as mulheres 
estavam no contexto de uma parceria estável. Elas acrescentaram que o desejo do parceiro, assim como o desejo de ser mãe, foi fundamental para que elas planejassem a gestação. Assim, diante do contexto de uma parceria estável, possivelmente os projetos de constituição de família com filhos ocupam um lugar privilegiado nas trajetórias de vida das pessoas, e que não desaparecem com a chegada do HIV. Além disso, a maternidade também não muda de significado a partir do diagnóstico e as mulheres e/ou os casais encontram modos de seguirem com seus planos.

Um estudo epidemiológico realizado em Nairóbi (Quênia) acompanhou por dois anos 454 mulheres vivendo com HIV em parceria sorodiscordante, com o objetivo de identificar os fatores que influenciam na decisão de mulheres engravidarem após o diagnóstico de HIV. O estudo recrutou participantes em centros de testagem e aconselhamento, e durante o período de acompanhamento havia visitas trimestrais para o seguimento dessas mulheres. Um dado relevante é que o estudo encontrou uma relação inversa entre tempo de duração da relação e desejo de engravidar por parte das mulheres. Nesse caso, para mulheres com uma relação mais recente, havia maior proporção de relatos sobre o desejo de engravidar (GUTHRIE et al. 2010). ${ }^{7}$ Tal dado pode ter relação com os significados sociais da maternidade no plano das relações, em que dar um filho ao marido é uma forte expectativa social direcionada às (e sustentada pelas) mulheres (BERTAGNOLI; FIGUEIREDO, 2017).

Outro estudo internacional realizado na África Subsaariana analisou dados de mais de quatro mil mulheres usuárias de serviços para tratamento do HIV. O objetivo do estudo era verificar a relação entre o uso de TARV e aumento do número de gravidezes naquela localidade. $O$ estudo verificou que o acesso a TARV, somado a melhores informações relativas aos riscos da transmissão vertical, promovem um cenário de maior segurança para as mulheres no que concerne às decisões reprodutivas e aumento das taxas de

\footnotetext{
${ }^{7} \mathrm{O}$ estudo Genih não consegue dimensionar precisamente o tempo do relacionamento até a ocorrência da gravidez; optou-se por solicitar à informante que classificasse se o tipo de parceria envolvido no episódio de gravidez, ou seja, se parceiro eventual ou estável.
} 
gestações em MVHA. Contudo, nele também se destaca a coabitação com parceiro dentre os fatores independentes associados a ocorrência e planejamento de gravidez (MYER et al. 2010).

Outro elemento diz respeito à estrutura de vida propiciada através de uma relação estável que, mesmo no contexto do HIV, pode promover possibilidades reais e palpáveis, nas quais ter e criar filhos pode se tornar uma realidade mais segura. De acordo com resultados de um estudo transversal realizado no estado de São Paulo entre os anos de 2011 e 2013, com o intuito de descrever os determinantes relacionados ao planejamento da gravidez, coabitar com o parceiro é um dos principais fatores associados positivamente com o planejamento da gravidez, pois formava um cenário de maior estabilidade para as mulheres (SANTOS; ROSA: BORGES, 2015).

Um outro fator associado ao planejamento da primeira gestação de mulheres vivendo com HIV após o diagnóstico é já ter tido filho antes do diagnóstico. Há um incremento de 0,85 na chance de planejar a gravidez em mulheres que já tinham filho antes do diagnóstico, quando comparadas a mulheres que não tinham filhos antes do diagnóstico.

Inicialmente, é fundamental considerarmos que as mulheres que já tinham pelo menos um filho antes de serem diagnosticadas com HIV provavelmente já haviam passado pela experiência do pré-natal e podem não apenas ter tido a oportunidade de participar de aconselhamento pósconcepcional, mas também de já terem sido inseridas em serviços de saúde com acompanhamento regular em programas de assistência à saúde da mulher.

Resultados de uma pesquisa realizada nos Estados Unidos no ano de 2014, que tinha o objetivo de medir os preditores relativos ao planejamento da gravidez em mulheres vivendo com HIV, também demonstraram que há maiores chances para o planejamento da gravidez em mulheres que já possuíam ao menos um filho antes do diagnóstico por HIV (risco relativo= 0,67, (I.C 95\%: 0,47; 0,94,) p =0,02) (RAHANGDALE et al. 2014). Um estudo realizado em Marília, município situado no estado de São Paulo em 2011, com o objetivo de estimar a prevalência e investigar os fatores associados ao 
planejamento da gravidez também verificou associação estatisticamente significativa entre o planejamento gestacional e já ter tido filho: $64,3 \%$ das mulheres que já tinham filho declararam ter planejado a gravidez, enquanto apenas $35,7 \%$ das que estavam na primeira gestação declaram ter planejado ( $p=0,044$ ) (BORGES, et al., 2011).

A história reprodutiva pregressa das mulheres pode proporcionar à elas ensinamentos e experiências que produzem efeitos/desdobramentos. $\mathrm{O}$ aprendizado no sentido da concepção, por exemplo, pode criar um cenário no qual a chegada de outra criança necessariamente deveria ser planejada. A pergunta que fica nesse caso é: o que leva uma mulher que já tem pelo menos um filho antes do diagnóstico planejar uma gravidez após a descoberta do HIV. Algumas especulações podem ser feitas. A primeira se refere aos projetos de vida da mulher e do parceiro relativos ao tamanho de família desejado. Mas há uma tensão aqui: é importante trazer para a cena o fato de que, no Brasil, a média do número de filhos por mulher diminuiu muito nos últimos anos, estando abaixo da média dos países da América Latina e inferior ao nível ideal para a manutenção do tamanho da população: atualmente a taxa de fecundidade total é de aproximadamente 1,7 filhos por mulher (o nível de reposição populacional é de 2,1 filhos por mulher - ROCHA, 2018). Todavia, ainda é forte a representação no contexto brasileiro de que o tamanho ideal de família é aquele com dois filhos, prioritariamente um casal. Esse dado é relevante quando consideramos que mulheres com apenas um filho possam ainda não ter alcançado o tamanho almejado de família. Assim, o desejo por ter mais um filho talvez faça parte de um determinado planejamento reprodutivo em busca da concretização da fecundidade desejada (PNDS,2006). Nesse plano, as mulheres que já possuíam filho antes do diagnóstico poderiam, por exemplo, não ter alcançado o número de filhos desejados e, portanto, planejar uma gravidez seria uma questão relevante.

GUTHRIE et al. 2010, em estudo epidemiológico que acompanhou MVHA em parceria sorodiscordante, identificou que em famílias que já possuíam ao menos um filho, havia maior chance para o planejamento de uma gestação após o diagnóstico. Os dados se aproximam aos resultados do 
nosso estudo, em que ter filho antes do diagnóstico foi associado ao planejamento da gestação após o diagnóstico.

Outra questão importante que poderia ter ocorrido neste cenário é troca de parceria. Considerando as expectativas sociais relativas ao papel da mulher no contexto de uma parceria afetivo-sexual, ter um novo parceiro poderia produzir um cenário no qual a mulher desejasse "dar um filho" a este novo parceiro (BERTAGNOLI; FIGUEIREDO; 2017). Não podemos chegar a alguma conclusão acerca disso com os nossos dados, mas esta é uma reflexão a se fazer. Um exemplo que pode ser citado é o resultado presente no estudo realizado no Quênia (GUTHRIE et al. 2010), descrito anteriormente, em que mulheres em parceria mais recente relatavam em maior proporção o desejo de engravidar, quando relacionadas as mulheres com parcerias mais duradouras e maior número de filhos.

PILECCO (2014), em sua tese de doutorado intitulada Aborto provocado em mulheres vivendo com HIV/Aids, entrevistou mulheres vivendo e não vivendo com HIV na cidade de Porto Alegre (RS). Os resultados de sua tese demonstraram que a maioria dos abortos provocados relatados pelas MVHA ocorriam antes do diagnóstico de HIV. No entanto, PILECCO (2014) faz um questionamento que também nos é pertinente: será que algumas dessas mulheres que já haviam realizado um aborto buscaram atendimento de saúde em decorrência deste? Se sim, será que os serviços de saúde perderam uma oportunidade crucial para a abordagem de temas relativos a decisões sexuais e reprodutivas, como, por exemplo, o uso da camisinha nas relações sexuais? No caso das informantes analisadas por PILECCO (2014), as mulheres foram infectadas pelo HIV após o episódio de aborto.

Embora PILECCO (2014) tenha identificado maior chance para o abortamento induzido em mulheres que vivem com HIV, quando comparadas com mulheres que não vivem com HIV, a autora verificou que para esses dois grupos as razões apontadas para a realização do aborto são as mesmas. Ainda que o HIV possa produzir efeitos nas decisões reprodutivas, dentre elas o aborto, a situação socioeconômica e ausência de apoio social do parceiro ou da família, e não ter planejado a gestação, se destacam entre os fatores 
comumente associados a prática do aborto.

Nesse sentido, podemos fazer um paralelo entre estes dois estudos com a seguinte reflexão: é possível que as mulheres que haviam provocado pelo menos um aborto antes do diagnóstico por HIV estivessem inseridas em contextos socioeconômicos desfavoráveis, bem como já teriam vivenciado uma gravidez não planejada em um momento anterior. Ou seja, parte dessas mulheres que não planejaram a gestação após o diagnóstico pelo HIV poderia estar submetida a elementos que compõem uma trajetória de maior vulnerabilidade em termos de decisões sexuais e reprodutivas, uma vez que essas mulheres haviam abortado, e, após esse evento, infectaram-se por HIV. Situação econômica instável, falta de apoio do parceiro, ausência de rede de apoio familiar, perda de oportunidades por parte dos serviços de saúde em termos da abordagem relativa a práticas sexuais e reprodutivas, seriam exemplos desses elementos que constituiriam essa trajetória (PILECCO, 2014). Nota-se que os elementos dessas trajetórias podem corresponder não somente a vulnerabilidade para o aborto induzido, mas também para a infecção por HIV. Assim, o paralelo a ser feito é pensar uma espécie de contraface aproximada a estes elementos, ou seja, parceria estável, filho antes do diagnóstico e mulheres sem história prévia de aborto induzido, associados ao planejamento de gravidez.

BORGES et al. $2011 \mathrm{em}$ um estudo que buscou descrever os fatores associados ao planejamento da gestação no contexto do HIV também identificou associação entre ausência de abortamento anterior ao diagnóstico e planejamento da gravidez após o diagnóstico de HIV. Mais uma vez, cabe refletir se mulheres com história de interrupção de gravidez guardam especificidades em suas trajetórias, que incidem em suas decisões sexuais e reprodutivas.

A literatura brasileira aponta que a epidemia de HIV/Aids em mulheres apresenta estreita relação com disparidades de gênero e situação econômica desfavorável (PARKER; GALVÃO, 1996; PARKER; BASTOS, 2001). Além disso, a situação da violência de gênero no contexto de mulheres com HIV/Aids é um problema de alta magnitude no Brasil, sobretudo na população 
mais pobre (CECCON; MENEGHEL, 2017). Esse perfil de mulheres mais suscetíveis ao HIV se assemelha ao perfil de mulheres que estão mais expostas a uma gravidez não planejada e a um aborto na trajetória, eventos que também estão ligados a diferenças sociais e econômicas. COELHO et al. 2012 apontam para o fato, por exemplo, de que mulheres pardas e pretas estão mais propensas a ter uma gestação imprevista quando comparadas as mulheres brancas, o que também está ligado a baixos níveis de escolaridade e baixa renda familiar.

DINIZ, SOUZA e PORTELLA (2005) afirmam que para as mulheres brasileiras, as escolhas reprodutivas possuem relação com o contexto mais amplo das relações de gênero, que se desdobram nos diversos espaços em que as mulheres estão submetidas, como o ambiente familiar e o trabalho. A esses espaços estão relacionadas diversas dimensões da vida das mulheres, como é o caso da ocorrência de violência doméstica, representações do matrimônio, acesso à educação e à saúde. Nesse trabalho, observou-se que o perfil das mulheres que não planejam a gestação no contexto da infecção por HIV se assemelha ao perfil da população geral de mulheres que não planejam a gestação. O nível de escolaridade baixo para mais da metade das mulheres desse estudo, a presença de aborto na trajetória antes do diagnóstico por HIV, que sugere a ocorrência de uma gestação não planejada anterior, além da possível falta de apoio do parceiro e da família, são demonstrativos dessas similaridades (THOMÉ, 2016; PILECCO; 2014).

O que então tornaria as mulheres vivendo com HIV mais propensas a uma gestação imprevista, quando relacionadas com a população geral? Esse questionamento nos leva novamente a reflexão de que, provavelmente, existam especificidades nas trajetórias de algumas mulheres, que compõem contextos de maior vulnerabilidade, que predisporiam estas mulheres à maiores riscos de infecção pelo HIV e ao não planejamento gestacional. A infecção por HIV em mulheres possui estreita relação com trajetórias de maior vulnerabilidade social, além de estar relacionada à dimensão relacional da vida das mulheres (PINHO et al. 2018; PINHO; CABRAL: BARBOSA, 2017). VILLELA e BARBOSA (2016) argumentam que o modo com que a infecção 
do HIV ocorre em mulheres não mudou muito ao longo das quatro décadas da epidemia no país. Ainda há intensa relação com as desigualdades de gênero, e o perfil das mulheres infectadas revela um quadro de vulnerabilidade social, com baixos níveis de escolaridade, inserção precária no mercado de trabalho, além da presença de violência na vida.

É essencial discutir sobre os papéis dos serviços de saúde durante todo esse processo relacionado ao planejamento reprodutivo no Brasil. Apesar dos diversos avanços no cuidado a saúde de mulheres vivendo com HIV no país, em uma pesquisa realizada no ano de 2007 , constatou-se diversos problemas na assistência à saúde de gestantes com HIV, desde a negação a informações fundamentais para as mulheres, até a atenção incompleta pelos profissionais de saúde à essas mulheres, de modo a não cumprir com as recomendações do Ministério da Saúde em relação ao conjunto de práticas que diminuem os riscos de transmissão vertical (BARROSO e GALVÃO, 2007).

O desejo de ter filhos após o diagnóstico de HIV deve ser um assunto abordado durante o tratamento das PVHA. Para além da prevenção da transmissão vertical, que é um desafio de longa data para o Sistema Único de Saúde, esta abordagem deve ser realizada com o intuito de promover informações e garantir direitos, ampliando as possibilidades de concepção segura (BRASIL, 2010). O planejamento reprodutivo deve ser entendido e discutido como um conceito amplo que envolve mais do que informações técnicas e acesso a métodos contraceptivos. Ele engloba um conjunto de ações que oferecem informações e recursos, tanto para uma gestação segura quanto para prevenir uma gestação imprevista. Isto implica em projetos individuais e relacionais, incluindo a composição familiar que cada indivíduo deseja ter (BRASIL, 2010).

Embora as questões que envolvem a concepção estejam inseridas na dimensão relacional, tradicionalmente, são colocadas como problemas de responsabilidade individual das mulheres. É imprescindível que os programas de planejamento reprodutivo transcendam esse imaginário. Nesse sentido se faz necessário ter como premissa a noção de corresponsabilidade do parceiro no âmbito da saúde sexual e reprodutiva, em que o homem (no caso de casais 
heterossexuais) deixa de ser passivo nesse contexto e passa a fazer parte das ações e tomadas de decisão, desde o planejamento da gestação até a educação e criação dos filhos (BRASIL, 2010).

É essencial que os serviços de saúde ofereçam orientações no âmbito pré- concepcional no sentido da promoção da saúde sexual e reprodutiva de mulheres vivendo com HIV. Isso possibilita a implementação de medidas, tanto no que diz respeito ao tratamento do HIV, que permite reduzir a carga viral a níveis indetectáveis e melhoria das condições imunológicas e, desse modo, produzir um cenário mais seguro para uma gestação com riscos reduzidos de transmissão vertical do HIV, quanto para propiciar o acesso a métodos anticoncepcionais às mulheres. Nos casos em que as mulheres desejarem uma gestação, cabe também aos serviços proporcionar o acompanhamento adequado para 0 planejamento da gravidez e acompanhamento pré-natal.

BARBOSA, VILELA e UZIEL (1995) atentavam, já na década de 1990, para a necessidade de disponibilização de métodos contraceptivos eficazes de controle exclusivamente feminino, considerando as dificuldades de negociação com o parceiro em relação ao uso do preservativo. Todavia, as autoras também ressaltavam que estratégias técnicas de contracepção e prevenção de ISTs não são suficientes para solucionar as questões que permeiam o cenário da saúde sexual e reprodutiva. É fundamental investigar e buscar compreender as questões e problemas, inseridos nas diversas dimensões da vida que sustentam as assimetrias de gênero e interferem também no modo como as pessoas, principalmente mulheres conseguem ou não, tomar decisões e agir em relação à proteção de sua saúde. 


\section{Considerações Finais}

Nesse trabalho, tomamos como objeto de estudo o contexto da primeira gestação após o diagnóstico de HIV em mulheres e inseridas em serviços especializados de saúde no município de São Paulo. O presente estudo enfocou na identificação dos fatores relacionados ao planejamento dessa gravidez. A partir desse recorte, o estudo permitiu a produção de dados e reflexões acerca da saúde reprodutiva de mulheres vivendo com HIV/Aids, especificamente aquelas residentes no município de São Paulo.

A saúde reprodutiva não é uma dimensão isolada da vida das mulheres, sobretudo no que tange ao planejamento de uma gestação. Este não é um evento simples e independente, mas repleto de complexidades, e cercado por condicionantes sociais e culturais. Esse cenário se torna ainda mais complexo quando se considera o fato de que as questões analisadas nesse estudo se deram diante do contexto da infecção por HIV.

A análise estatística a partir de dimensões estratificadas nos possibilitou examinar detidamente os diversos elementos que poderiam estar relacionados ao planejamento da primeira gestação após o diagnóstico do HIV. Isso nos permitiu ter uma ideia mais abrangente sobre as principais dimensões da vida dessas mulheres associadas ao processo de planejamento de uma gravidez.

Os resultados desse estudo demonstraram que as mulheres vivendo com HIV com pelo menos uma gestação após o diagnóstico são, na maioria, brancas, com baixo nível de escolaridade (ensino médio incompleto ou menos), possui mais de 25 anos e a maior parte foi diagnosticada até os 24 anos, ou seja, em idade reprodutiva. Apenas um terço das gestações após o diagnóstico foram planejadas, o que é preocupante e complexo ao mesmo tempo, dado que essas mulheres já haviam sido diagnosticadas com HIV e estavam inseridas em serviços de saúde especializados.

Os fatores associados ao planejamento da gestação foram: coabitação com parceiro; ter filho antes do HIV; ausência de aborto provocado antes do diagnóstico. Tais dados se assemelham aos fatores associados ao 
planejamento da gravidez na população geral. Contudo, observa-se uma maior proporção de não planejamento da gravidez em mulheres com HIV. Somado a isto, temos o fato de que as especificidades sociais que tornam as mulheres mais suscetíveis a uma gravidez não planejada são semelhantes às especificidades sociais que às tornam mais suscetíveis a infecção por HIV, tais como: dificuldades de negociações das práticas sexuais seguras; significados sociais do papel da mulher; disparidades de gênero; falta de apoio no âmbito familiar e na parceria; condições socioeconômicas desfavoráveis. Além disso, é importante salientar que a maternidade é um espaço culturalmente construído para as mulheres, e qualquer outro espaço é preciso construir.

Chama atenção a alta proporção de não planejamento da gravidez, principalmente quando se considera que as mulheres estavam inseridas em serviços especializados de HIV/Aids. Esse quadro também suscita uma discussão relativa ao modo como as políticas e ações de enfrentamento a epidemia de HIV vem se transformando nos últimos anos no Brasil. Observase uma tendência de centralização biomédica no que tange as políticas públicas e atenção à saúde em termos de prevenção e tratamento do HIV no país.

No cenário nacional e internacional, pesquisadores vem apontando a necessidade de investir em ações com enfoque comportamental e que façam sentido para as pessoas (BRASIL, 2017; KUCHENBECKER; 2015; FERRAZ e PAIVA, 2015; ABIA, 2018). Além disso, é fundamental interligar os serviços de planejamento familiar aos serviços de tratamento às pessoas que vivem com HIV com vistas a promover ações que incidam eficazmente para a diminuição das taxas de gravidez imprevista, como também prevenir a transmissão vertical.

Os resultados do presente estudo nos mostram que o planejamento da gravidez no contexto do HIV é permeado por questões relativas às dimensões sociais e relacionais, e escapam da lógica sanitária e do controle biomédico. Contudo, ao fazer tal afirmação não buscamos reivindicar novas tecnologias biomédicas de controle ou impedimento da gestação dessas mulheres. São 
necessárias reflexões que problematizem essa realidade, que transcendam a lógica biomédica e de controle, que abram-se espaços para ouvir e produzir diálogos de modo a auxiliar as mulheres em suas decisões, sem lhes retirar a autonomia e direito de escolha (BRANDÃO; CABRAL, 2017).

Acrescenta-se a este complexo cenário o preocupante desmonte da política brasileira de combate ao HIV/Aids em curso. Apesar de a contenção do HIV/Aids e da Hepatite C representar um dos objetivos da OMS, sem contar o fato do Brasil ser - até então - um país modelo no que tange ao enfrentamento da epidemia da Aids, diversos setores da saúde pública vêm sofrendo com diversas medidas de austeridade por parte do governo brasileiro. No ano de 2016, por exemplo, o governo de Michel Temer do MDB (Movimento Democrático Brasileiro) assinou a emenda constitucional 95, que condiciona, por 20 anos, os investimentos públicos em saúde ao reajuste da inflação. A medida mais atual que atingiu diretamente o setor das ISTs foi a mudança no antigo Departamento que era dedicado ao tratamento e prevenção de HIV/Aids, hepatites e outras ISTs e que agora passa a ser chamado Departamento de Doenças de Condições Crônicas e Infecções Sexualmente Transmissíveis (DIAHV). Nele, o HIV/Aids e outras ISTs serão tratadas juntamente com verminoses, infecções virais e bacterianas. Além de as prioridades de enfrentamento da epidemia de HIV terem sido rebaixadas, os demais agravos que compõem o novo departamento possuem abordagens e formas de enfrentamento diferentes. Mais ainda, os condicionantes sociais associados ao HIV por exemplo, são extremamente diferentes desses outros agravos (FIGUEIREDO, 2019; ABIA, 2018; ABIA 2019).

Em termos de posicionamento institucional para o delineamento de ações de combate ao HIV, é importante salientar a Coordenação Estadual de IST/Aids da Secretaria de Saúde do Estado de São Paulo publicou a Nota informativa de número 02/2017 intitulada "Indetectável é igual a Intransmissível - I = I", na qual determina que:

A pessoa vivendo com HIV/Aids com carga viral indetectável há pelo menos 6 meses e boa adesão ao tratamento tem um risco insignificante de transmitir o vírus pela via sexual [...] Infecções 
sexualmente transmissíveis (IST) e possíveis pequenos aumentos transitórios na carga viral (conhecidos clinicamente como "blips") não influenciam a transmissibilidade nestes casos, de acordo com os estudos (CRT DST/Aids, 2017).

A intransmissibilidade como consequência da indetectabilidade da carga viral de pessoas vivendo com HIV é tomada como posição central das políticas mais atuais em torno da atenção a saúde pessoas vivendo com HIV. Partindo desse ponto, por tratar-se de uma infecção transmitida sexualmente, além do fato de que o HIV não significa a interrupção da vida sexual e reprodutiva de mulheres diagnosticadas com o vírus, é fundamental o aprofundamento de investigações científicas em torno dos efeitos do HIV no âmbito sexual e reprodutivo de mulheres que vivem com HIV. Contudo, ao que parece, os serviços de saúde ainda mantêm a camisinha como elemento central de prevenção da transmissão. Além de falhas no processo de tratamento e prevenção, que demonstram insuficiências nas políticas públicas e ações de saúde relativas ao enfrentamento da epidemia de HIV no Brasil, assistimos um desmonte das políticas públicas direcionadas ao enfrentamento das ISTs. A exemplo disso, pode-se citar a mudança no Departamento de Vigilância, Prevenção e Controle das IST, do HIV/Aids e das Hepatites Virais, que passa a se chamar Departamento de Doenças de Condições Crônicas e Infecções Sexualmente Transmissíveis (DIAHV). Nesse novo contexto, o HIV/Aids e outras ISTs serão tratadas juntamente com verminoses, infecções virais e bacterianas, cujos determinantes sociais possuem profundas diferenças. Portanto, se em um cenário no qual as políticas públicas eram direcionadas de forma direta e exclusiva ao enfrentamento do HIV/Aids, encontramos resultados como os nossos (de altas taxas de gravidez não planejada no contexto do HIV), o que se pode esperar em um cenário no qual as ações destinadas ao HIV/Aids estarão, de certa maneira, mais diluídas e/ou com atenção inespecífica? Infelizmente, encerramos o texto desta dissertação em um cenário bastante desolador no que concerne ao enfrentamento da epidemia de HIV/Aids pelo Estado brasileiro. 


\section{REFERÊNCIAS BIBLIOGRÁFICAS}

ABIA. Entenda o desmonte da resposta à Aids no Brasil. Redação da Associação Brasileira Interdisciplinar de Aids, 2019.

ABIA. Desmonte do SUS prejudica tratamento de infecções sexualmente transmissíveis. Redação da Associação Brasileira Interdisciplinar de Aids, 2018.

AGÊNCIA AIDS. Soropositivos que tomam antirretrovirais e que cuidam bem da saúde têm a mesma expectativa de vida que uma pessoa sem HIV, indicam estudos. Redação da Agência de Notícias da Aids, 2010.

AGÊNCIA AIDS. Mulheres soropositivos podem ter filhos sem HIV. Redação da Agência de Notícias da Aids, 2018.

AGÊNCIA FIOCRUZ. Filho de infectada com o HIV nasce sem o vírus. Redação da Agência FIOCRUZ, 2008.

ANDREANI, Tatiana et al. Topical Targeting Therapies for Sexually Transmitted Diseases. Current Nanoscience, Vol. 8, No. 4, 2012.

BAJOS, Nathalie; MARQUET, Jacques. Research on HIV sexual risk: Social relations- based approach in a cross-cultural perspective. Social Science and Medicine, Volume 50, Issue 11, June 2000, Pages 1533-1546.

BASTOS, Cristiana. Ciência, poder, acção: as respostas a SIDA. Imprensa das Ciencias Sociais da Universidade de Lisboa. Lisboa-Portugal, 2002.

BARATA, Germana Fernandes. A primeira década da AIDS no Brasil. O Fantástico apresenta a doença ao público (1983 - 1982). Departamento de História da Faculdade de Filosofia e Ciências Humanas da Universidade de São Paulo. 2006.

BARBOSA, Regina M.; PINHO, Adriana A.; CABRAL, Cristiane S. Gênero, reprodução e infecção pelo Hiv: resultados do estudo GENIH. Campinas, SP: 
Núcleo de Estudos de População “Elza Berquó” / Unicamp, 2016.

BARBOSA, Regina Maria. Um olhar sobre a epidemia de AIDS. In: Sexo e Vida: Panorama da Saúde Reprodutiva no Brasil/ Elza Berquó (org.) Campinas, SP; Editora da UNICAMP, 2003.

BARBOSA, Regina Maria; KOYAMA, Mitti Ayako Hara. Comportamento e práticas sexuais de homens e mulheres, Brasil 1998 e 2005. Revista de Saúde Pública, 2008.

BARBOSA, Regina Maria et al. Differences in the Access to Sterilization between Women Living and Not Living with HIV: Results from the GENIH Study, Brazil. Plos One, v. 11, p. e0164887, 2016.

BARBOSA, Regina Maria; PINHO, Adriana de Araujo; CABRAL, Cristiane da Silva. Gênero, reprodução e infecção pelo HIV: resultados do estudo GENIH. Textos NEPO (UNICAMP), v. 78, p. 1, 2016.

BARROS, Aluísio J.D.; HIRAKATA Vânia N. Alternatives for logistic regression in cross-sectional studies: an empirical comparison of models that directly estimate the prevalence ratio. BMC Medical Research Methodology 2003.

BASTOS, Francisco Inácio. Aids na Terceira Década. Editora FIOCRUZ, Rio de Janeiro, 2006.

BARROSO, L. M. M.; GALVÃO, M. T. G. Avaliação de atendimento prestado por profissionais de saúde a puérperas com HIVIAIDS. Texto contexto enferm. 2007.

BIEHL, João. Antropologia no Campo da Saúde Global. Horiz. antropol. vol.17 no.35 Porto Alegre Jan./Jun 2011.

BORGES, Ana Luiza Vilella. et al. Planejamento da gravidez: prevalência e aspectos associados. Revista da Escola de Enfermagem da USP 45 (esp.2): 1679- 84, 2011.

BOZON, Michel; HEILBORN, Maria Luiza. Iniciação à sexualidade: modos de 
socialização, interações de gênero e trajetórias individuais. In: HEILBORN, M. L. et al. (Org.). O aprendizado da sexualidade: reprodução e trajetórias sociais de jovens brasileiros. Rio de Janeiro: Fiocruz, 2006. p. 156-206.

BIBLIQMED. Linha do Tempo da AIDS: Do Primeiro Caso aos Dias Atuais. Artigos de Saúde. Boa Saúde, Brasil, 2012. http://www.boasaude.com.br/artigos-de- saude/3837-1/linha-do-tempo-daaids-do-primeiro-caso-aos-dias-atuais.html. Acessado em novembro de 2017.

BRANDAO, Elaine Reis; CABRAL, Cristiane da Silva. Da gravidez imprevista à contracepção: aportes para um debate. Cad. Saúde Pública, Rio de Janeiro, v. 33, n. 2, e00211216, 2017.

BRASIL. História da Aids. PNDST 2015 - Departamento de DST, Aids e Hepatites Virais: portal sobre Aids, doenças sexualmente transmissíveis e hepatites virais. Site: http://www.aids.gov.br/pagina/historia-da-aids. Acessado em janeiro de 2018.

BRASIL. Cinco passos para a prevenção combinada ao HIV na atenção básica. Ministério da Saúde, 2017.

BRASIL. Boletim Epidemiológico- HIV/Aids 2017. Secretaria de Vigilância em Saúde - Ministério da Saúde, 2017.

BRASIL. Artigo 5o da Lei nº 9.263, de 12 de janeiro de 1996. Brasília, 12 de janeiro de 1996.

BRASIL. Direitos sexuais e reprodutivos: uma prioridade do governo. Série Direitos Sexuais e Reprodutivos - Caderno no․ 1. Ministério da saúde, Brasília - DF, 2005.

BRASIL. Protocolo Clínico e Diretrizes Terapêuticas Para Prevenção da Transmissão Vertical De HIV, Sífilis e Hepatites Virais. Ministério da Saúde. Brasília- DF. 2018.

BRASIL. Pesquisa Nacional de Demografia e Saúde da Criança e da Mulher 
- PNDS 2006. Ministério da Saúde. Centro Brasileiro de Análise e Planejamento. Brasília - DF. 2009.

CABRAL, Cristiane da Silva. Práticas contraceptivas e gestão da heterossexualidade: agência individual, contextos relacionais e gênero. Tese de doutorado. Universidade do Estado do Rio de Janeiro. Instituto de medicina Social. Rio de janeiro. 2011.

CECCON, Roger Flores; MENEGHEL, Stela Nazareth. Iniquidades de gênero: mulheres com HIV/Aids em situação de violência. Physis 27 (04) Oct-Dec 2017.

COELHO, Edméia de Almeida Cardoso et al. Associação entre gravidez não planejada e o contexto socioeconômico de mulheres em área da Estratégia Saúde da Família. Acta paul. enferm. vol.25 no.3 São Paulo 2012.

CONRAD, Peter. The Medicalization of Society: On The Transformation Of Human Conditions Into Treatable Disorders. Johns Hopkins University Press, Baltimore, 2007.

CORRÊA, Sonia; ÁVILA, Maria Betânia. Direitos Sexuais e Reprodutivos Pauta Global e Recursos Brasileiros. In: Sexo e Vida: Panorama da Saúde Reprodutiva no Brasil/ Elza Berquó (org.) - Campinas, SP; Editora da UNICAMP, 2003.

CORRÊA, Sonia; ALVES, José Eustáquio Diniz; DE MARTINO JANNUZZI, Paulo. Direitos e saúde sexual e reprodutiva: marco teórico-conceitual e sistema de indicadores. Livros, p. 27-62, 2015.

CORREA, Sonia. "Saúde reprodutiva", gênero e sexualidade: legitimação e novas interrogações. In: GIFFIN, Karen; COSTA, Sarah Hawker (orgs.). Questões de saúde reprodutiva. Rio de Janeiro: Fiocruz, p.39-49, 1999.

CUNHA, Claudia Carneiro. Os muitos reveses de uma" sexualidade soropositiva": o caso dos jovens vivendo com HIV/AIDS. Revista Latinoamericana- Sexualidad, salud y sociedad. abr. 2012. p (70-99). 
DOURADO, Inês; et al. Tendências da epidemia de Aids no Brasil após a terapia anti- retroviral. Rev Saúde Pública 2006;40(Supl).

ENGLERT, Y. Et al. ART in HIV-infected couples: Has the time come for a change of attitude? Human Reproduction, 16(7), 1309-1315. 2001

FIGUEIREDO, Cecília. "É o fim do Programa Brasileiro de Aids", denuncia movimento social. Revista Brasil de Fato, 2019.

FIGUEIREDO, Regina. Uso de preservativos, risco e ocorrência de gravidez não planejada e conhecimento e acesso à contracepção de emergência entre mulheres com HIV/Aids. Ciência \& Saúde Coletiva, 15(Supl. 1):1175-1183, 2010.

FERAZ, Dulce; PAIVA, Vera. Sexo, direitos humanos e AIDS: uma análise das novas tecnologias de prevenção do HIV no contexto brasileiro. Rev. bras. epidemiol. vol.18 supl.1 São Paulo Sept. 2015.

FLORIDIA, M. et al. Short Report: Pregnant with HIV before age 25: data from a large national study in Italy, 2001-2016. Cambridge University Press. Epidemiol. Infect. 2017.

FOUCAULT, Michel. História da Sexualidade. Rio de Janeiro; Graal; 8 ed; 1985. 152. p. (Biblioteca de Filosofia e História das Ciências, 2).

GONÇALVES, Tonantzin Ribeiro et al, 2009. Vida reprodutiva de pessoas vivendo com hiv/aids: revisando a literatura. Psicologia \& Sociedade; 21 (2): 223-232, 2009.

GONÇALVES, Tonantzin Ribeiro et al. Vida reprodutiva em portadores do HIV/Aids: revisando a literatura. Psicologia \& Sociedade; 21 (2): 223-232, 2009.

GUTHRIE, Brandon L. et al. Predicting Pregnancy in HIV-1-Discordant Couples. Springer Science+Business Media, LLC 2010.

HEILBORN, Maria Luiza et al. Aprendizado da Sexualidade, Reprodução e 
Trajetórias Sociais de Jovens Brasileiros. Editora Garamond; Edição: $1^{\text {a }}$ - 12 de julho de 2006.

HERZLICH, Claudine. Saúde e doença no início do século XXI: entre a experiência privada e a esfera pública. PHYSIS: Rev. Saúde Coletiva, Rio de Janeiro, 14(2):383- 394, 2004.

HERZLICH, Claudine; PIERRET, Janine. Uma Doença no Espaço Público. A AIDS em Seis Jornais Franceses. PHYSIS: Rev. Saúde Coletiva, Rio de Janeiro, 15(Suplemento):71-101, 2005.

IBGE. SIS 2010: Mulheres mais escolarizadas são mães mais tarde e têm menos filhos. Instituo Brasileiro de Geografia e Estatística, Censo 2010.

IBGE. Pesquisa Nacional de Saúde. Ciclos de Vida, Brasil e grandes regiões. 2013.

KNAUTH, Daniela Riva; BARBOSA, Regina Maria; HOPKINS, Kristine. Between personal wishes and medical "prescription": Mode of delivery and post- partum sterilization among women with HIV/Aids in Brazil. Reproductive Health Matters, 11(22), 113-121. 2003.

KUCHENBECKER, Ricardo. Qual é o benefício das intervenções biomédicas e comportamentais na prevenção da transmissão do HIV? Rev. bras. epidemiol. vol.18 supl.1 São Paulo Sept. 2015.

KUROKAWA e SILVA, Neide Emy; ALVARENGA, Augusta Thereza de; AYRES, José Ricardo de C. M. Aids e gravidez: o sentido do risco e o sentido do cuidado. Revista de Saúde Pública, 2006.

LIN, D.Y; WEI L.J. The robust Inference for the Cox Proportional Hazards Model. J Am Stat Assoc. 1989.

MARQUES, Maria Cristina. A História de uma epidemia moderna. A emergência política da AIDS/HIV no Brasil. Maringá: EDUEM, 2003.

MAYHEW, Suzannah et al. Fertility intentions and contraceptive practices 
among clinic-users living with HIV in Kenya: a mixed methods study. BMC Public Health, 2017.

MIRANDA, Angelica Espinosa et al. Avaliação da cascata de cuidado na prevenção da transmissão vertical do HIV no Brasil. Cad. Saúde Pública, Rio de Janeiro, 32(9):e00118215, set, 2016

MORELL, Maria G.G. et al, 2004. Órfãos e Aids: um desafio para o brasil. XIV Encontro Nacional de Estudos Populacionais, ABEP, realizado em CaxambúMG - Brasil, Setembro de 2004.

MOURA, Elisângela Santos de. O direito à saúde na Constituição Federal de 1988. Revista Âmbito Jurídico. Seção Constitucional. 2019.

NEVES, Lis Aparecida de Souza; GIR, Elucir. Crenças das mães soropositivas ao HIV acerca da transmissão vertical da doença.

NTAMBUE, Abel; et al. Determinants of maternal health services utilization in urban settings of the Democratic Republic of Congo - A Case study of Lubumbashi City. BMC Pregnancy and Childbirth, 2012.

OLINTO, Maria Teresa Anselmo; MOREIRA-FILHO, Djalma de Carvalho. Fatores de risco e preditores para o aborto induzido: estudo de base populacional. Cad. Saúde Pública, Rio de Janeiro, 22(2):365-375, fev, 2006.

PAIVA, Vera et al. Sexualidade de mulheres vivendo com HIVIAIDS em São Paulo. Cad. Saúde Pública, Rio de Janeiro, 18(6):1609-1620, nov-dez, 2002.

PAIVA, Vera et al. Sem direito de amar? A vontade de ter filhos entre homens (e mulheres) vivendo com o HIV. Psicologia USP, vol. 13, 2002.

PARKER, Richard; O fim da AIDS. $8^{\circ}$ Encontro Estadual das ONGs/AIDS do Rio de Janeiro, agosto de 2015.

PARKER, Richard et al. Conquistas e Desafios na Assistência ao HIVIAIDS. ASSOCIAÇÃO BRASILEIRA INTERDISCIPLINAR DE AIDS - ABIA, 2002. 
PARKER, Richard; TERTO Jr, Veriano; RAXACH, Juan C. Respostas ao HIV na América Latina. ASSOCIAÇÃO BRASILEIRA INTERDISCIPLINAR DE AIDS - ABIA, Bol. 44, 2000.

PARKER, Richard; BASTOS, F. I. P. M. A feminização da epidemia de AIDS no Brasil: determinantes estruturais e alternativas de enfrentamento, 2001.

PARKER, Richard; GALVÃO, Jane. Quebrando o Silêncio: Mulheres e AIDS no Brasil. Rio de Janeiro: Relume-Dumará; ABIA - IMS/UERJ, 1996.

PARKER, Richard; CAMARGO JR, Kenneth Rochel de. Pobreza e HIVIAIDS: Aspectos sociológicos e antropológicos. Cad. Saúde Pública, Rio de Janeiro, 16 (Sup.1):89-102, 2000

PINHEIRO, Thiago Félix. Camisinha, homoerotismo e os discursos da prevenção de HIV/aids. Faculdade de Medicina da USP, São Paulo, 2015.

PILECCO, Flávia Bulegon. Aborto provocado em mulheres vivendo com HIV/Aids. Tese de doutorado. Programa de pós-graduação em epidemiologia da Faculdade de Medicina da Universidade Federal do Rio Grande do Sul. 2014.

PILECCO, Flávia Bulegon et al. Aborto pós-diagnóstico em mulheres vivendo com HIV/Aids no sul do Brasil. Ciência \& Saúde Coletiva, 20(5):1521-1530, 2015.

PINHO, Adriana de Araujo et al. Drivers of Sexual Inactivity Among Women Living with HIV and AIDS: Findings of the GENIH Study in São Paulo, Brazil. ARCHIVES OF SEXUAL BEHAVIOR, v. 1, p. 1, 2018.

PINHO, Adriana de Araujo; CABRAL, Cristiane da Silva; BARBOSA, Regina Maria. Diferenças e similaridades entre mulheres que vivem e não vivem com HIV: aportes do estudo GENIH para as reflexões sobre integralidade de/nas ações em prevenção e cuidado à saúde sexual e reprodutiva. Cadernos de Saúde Publica, v.12, p. e00057916, 2017. 
PRAÇA, Neide de Souza; LATORRE, Maria do Rosário Dias de Oliveira. Saúde sexual e reprodutiva com enfoque na transmissão do HIV/Aids: práticas de puérperas atendidas em maternidades filantrópicas do município de São Paulo. Revista Brasileira de Saúde Materno Infantil, 3(1), 61-74.

RAHANGDALE, Lisa et al. Pregnancy Intentions Among Women Living With HIV in the United States. J Acquir Immune Defic Syndr - Volume 65, Number 3, March 1, 2014.

RAMRAJ, Trisha et al. Adolescent Access to Care and Risk of Early Motherto-Child HIV Transmission. Society for Adolescent Health and Medicine, 2017.

REPOPORT, Andrea; PICCINI, Cesar Augusto. SOCIAL SUPPORT AND THE EXPERIENCE OF MATERNITY. Rev Bras Crescimento Desenvolv Hum.16(1):85-96; 2006.

RIOS, Luís Felipe, et al. Os cuidados com a "carne" na socialização sexual dos jovens. Psicologia em Estudo (Impresso), v. 13, p. 673-682, 2008.

RIOS, Luís Felipe. Juvenilização do HIV/Aids por via sexual. Boletim ABIA no 49. Julho/Setembro de 2003.

ROMANELLI, Roberta M. C. et al. Efetividade da terapia anti-retroviral dupla e tríplice em crianças infectadas pelo HIV. J. Pediatr. (Rio J.) vol.82 no.4 Porto Alegre July/Aug. 2006.

ROSENTHAL, Caio.; SCHEFFER, Mário. AIDS: os fracassos da prevenção. Folha de São Paulo, Opinião / Tendências e Debates, p. A3 - A3, 01 dez. 2009. RUBIN, Gayle. El tráfico de mujeres: notas sobre la 'economia política' del sexo. Revista Nueva Antropología, vol. VIII, num. 030. México. 1986.

SANTOS, Naila Janilde Seabra. Mulher e negra: dupla vulnerabilidade às DST/HIV/Aids. Saude soc. 25 (3) Jul-Sep 2016.

SANTOS, Osmara Alves dos; ROSA, Patricia Lima Ferreira Santa; BORGES, Ana Luiza Vilela. Determinantes do planejamento da gravidez segundo a 
raça/cor em São Paulo, Brasil. Revista da Associação Brasileira de Pesquisadores/as Negros/as (ABPN), [S.I.], v. 7, n. 16, p. 74-88, jun. 2015.

SCHEFFER, Mário. Coquetel: A incrível história dos antirretrovirais e do tratamento da aids no Brasil. 1. ed. São Paulo: Hucitec: Sobravime, v. 1. 216p. 2012.

SEBITLOANE, H.M.; MHLANGA, R.E. Changing patterns of maternal mortality (HIV/AIDS related) in poor countries. Best Practice \& Research Clinical Obstetrics and Gynaecology Vol. 22, No. 3, pp. 489-499, 2008.

SILVA, Alex Giacomelli. Poder Inteligente - $A$ Questão do HIV/AIDS na Política Externa Brasileira. Contexto Internacional; Rio de Janeiro Vol. 27, Ed. 1, (JanJun 2005): 127-158.

SILVA, Luís Augusto de. Barebacking e a possibilidade de soroconversão. Cadernos de Saúde Pública, vol. 25, Rio de Janeiro, 2009.

SILVEIRA, Paula Morena Souto Derenusson. HIV como Elemento Biográfico no Curso de Vida: Implicações do I = I nas Trajetórias Afetivo-Sexuais de Mulheres. Projeto de Qualificação de Doutorado apresentado ao Programa de Pós-Graduação em Saúde Pública - Faculdade de Saúde Pública - USP. 2018.

SOUZA, Marcus Vinícius Nora de; ALMEIDA, Mauro Vieira de. Drogas anti VIH: passado, presente e perspectivas futuras. Química Nova, vol. 26, São Paulo, 2003.

TADANO, Yara de Souza; UGAYA, Cassia Maria Lie; FRANCO, Admilson Teixeira. Método de regressão de Poisson: metodologia para avaliação do impacto da poluição atmosférica na saúde populacional. Ambiente \& Sociedade. Campinas. Vol.: 12,n. 2; p. 241-255, 2009.

TEIXEIRA, Luciana Barcellos et al. Sexual and reproductive health of women living with HIV in Southern Brazil. Cad. Saúde Pública, Rio de Janeiro, 29(3):609- 620, mar, 2013. 
TEIXEIRA, Luciana Barcellos et al. Factors associated with post-diagnosis pregnancies in women living with HIV in the south of Brazil. PLOS ONE | DOI:10.1371/journal.pone. 2017.

TERTO Jr, Veriano. Homossexualidade e saúde: desafios para a terceira década de epidemia de HIVIAIDS. Horiz. antropol. vol.8 no.17 Porto Alegre June 2002.

THOMÉ, Clarissa. 55\% das mães não queriam ter filhos, aponta pesquisa. 0 Estado de S. Paulo 2016. Acessado em: https://brasil.estadao.com.br/noticias/geral,55- das-maes-nao-queriam-terfilhos-aponta-pesquisa, 10000092047

VANCE, Carol S. A antropologia Redescobre a Sexualidade: Um Comentário Teórico. Physis [online], vol.5, n.1, pp. 7-32, 1995.

VENTURA, Miriam. Direitos Reprodutivos no Brasil. São Paulo, 2002.

VENTURA, Miriam. Direitos Reprodutivos no Brasil. 3a Edição; 2009.

VERNAZZA, P. L. et al. HIV-discordant couples and parenthood: How are we dealing with the risk of transmission? AIDS, 20(4), 635-636. 2006.

VILLARIM, Adriane Bezerra. Os novos paradigmas do direito das famílias: $A$ consagração da afetividade pelos tribunais superiores rumo ao reconhecimento das uniões poliafetivas. TCC apresentado a Universidade Federal da Paraíba, 2018.

VILLELA, Wilza Vieira; BARBOSA, Regina Maria; et al. Motivos e circunstâncias para o aborto induzido entre mulheres vivendo com HIV no Brasil. Repositório da Produção Científica e Intelectual da UNICAMP. 2012.

VILLELA, Wilza Vieira; BARBOSA, Regina Maria. Trajetórias de mulheres vivendo com HIV/aids no Brasil. Avanços e permanências da resposta à epidemia. Cad. De Saúde Pública, 2016.

WABIRI, Njeri et al. Growing inequities in maternal health in South Africa: a 
comparison of serial national household surveys. BMC Pregnancy and Childbirth, 2016.

YILDIRIM, Yusuf; INAL, Murat; TINAR, Sivekar. Reproductive and Obstetric Characteristics of Adolescent Pregnancies in Turkish Women. J Pediatr Adolesc Gynecol, 2005. 
ANEXOS 


\section{FORMULÁRIO DE ELEGIBILIDADE}

\section{IDENTIFICAÇÃO}

ID: ( )( )( )( )( )( ) Data da entrevista: ( )( )/( )( )/( )( )

Serviço deSaúde:

ID do entrevistador: ( ) ( )

Nome do supervisor:

ID1. Tipo de grupo

01 ( ) MNVHA

02 ( ) MVHA

ID2. Característica do serviço selecionado:

Tipo de gestão

01( )SobgestãodiretadaSMS

02( ) Sobgestãodireta daSES

03 ( ) Sobgestão deterceiros

04 ( ) UNIFESP

05( ) outro.Especificar:

HORA DO INÍCIO DA ENTREVISTA: horas / minutos

ID3. Procura ao serviço: 01

( ) pré-agendada

02 ( ) não pré-agendada

ID4. Porque você veio aesse serviço hoje?(espontânea e múltipla)

01 ( ) consulta depré-natal

02 ( ) consulta ginecológica

03 ( )consultaougrupodeanticoncepção

04 ( ) consulta com infectologista

05 ( ) consulta para outros eventos (não relacionadas à ginecologia / pré-natal).

Quais?

a. ( ) hipertensão

b. ( ) diabetes

c. ( ) quadro respiratório

d. ( ) outro.

06 ( ) pegar remédio

07 ( ) coleta de material para exame:

a. ( ) prevenção de câncer de colo de útero.

b. ( )outro. Especificar:

08 ( ) marcar exame ou consulta

09( ) outromotivo. Especificar: 
ID4a. Quandofoisuaúltima consultamédica neste serviço? (Se não lembra o dia ou mês, deixe em branco)

()()$/()() /()()()()$

ID5. Você já respondeu a essa entrevista em outro momento?

01 ( ) sim (agradecer e não realizar a entrevista)

02 ( ) não

ID6. Qual sua idade? ( ) ( ) anos completos

ID7. Qual a sua data de nascimento? ( ) ( )/( ) ( )/( )( ) ( ) ( )

[Checar se a data da entrevista - data de nascimento= idade da entrevistada, caso contrário, checar novamente a idade e data de nascimento da entrevistada]

[Se idade $<18$ anos ou $>49$ anos, agradeça e não continue a entrevista]

ID8. Mulher concordou de participar?

01 ( ) sim (pular para ID10)

02 ( ) não (agradecer e não realizar a entrevista)

ID9. Entrevistadora, registre o motivo darecusa:

01 ( ) não temtempo

02 ( ) não tem interesse

03 ( ) nãogosto ou nãoquerofalar sobreminha vida

04( ) outro. Especificar:

ID10. Mulher concorda em ser contatada por telefone?

01 ( ) sim

02 ( ) não 


\section{A. PERFIL SÓCIO DEMOGRÁFICO}

Vamos começar com algumas perguntas sobre você e sua família.

A.1 Qualé suacor:(estimulada eúnica)

01 ( ) branca

02 ( ) preta

03 ( ) parda

04( )amarela(deorigem asiática)

05 ( ) indígena

77( ) não sabe

88 ( ) recusou-se a responder

A.2 Vocêtemalgumareligião?

01 ( ) sim

02 ( ) não (pular para A5)

77 ( ) não sabe (pular para A5)

88 ( ) recusou-se a responder (pular para A5)

A.3 Atualmente, qual á a sua religião ou culto? (espontânea eúnica)

01 ( ) católica

02 () pentecostal, evangélica

03 ( ) protestante

04 ( ) umbanda, candomblé, batuque

05 ( ) espírita

06 ( ) judaica

07 () mais deuma.Especificar:

08( ) outra. Especificar:

77 ( ) não sabe

88 ( ) recusou-se a responder

A.4 Areligião nasua vidaé:(estimulada eúnica)

01 ( ) muito importante

02 ( ) importante

03 ( ) um poucoimportante

04 ( ) não é importante

77 ( ) não sabe

88 ( ) recusou-se a responder

A.5 Tem/teve filhos (biológicos)?

01 ( ) sim

02 ( ) não (pular para A7)

88 ( ) recusou-se a responder (pular para A7)

A.6 Quantosfilhos?(vivosemortos)

( ) ( )

A.7 Ea sua mãe (biológicaoudeadoção) estáviva?

01 ( ) sim

02 ( ) não (pular para A9)

77 ( ) nãosabe

88 ( ) recusou-se a responder

A.8 Qual a idade da sua mãe?

( ) ( ) ( ) anos completos (777 para não sabe; 888 para recusa) 
A.9 Qualé/eraaescolaridade dela?(espontâneaeúnica)

01 ( ) nunca frequentou a escola

02( ) ensinofundamental incompleto

03 ( ) ensino fundamental completo

04 ( ) ensino médio incompleto

05( ) ensino médio completo

06 ( ) superior incompleto

07 ( ) superior completo

08 ( ) pós-graduação

77 ( ) não sabe/não lembra

88() recusou-se a responder

ATENÇÃO: As questões AY1 a AY3 somente devem ser aplicadas para as MVHA entre 18 e 24 anos

A.Y1 Porquantosanosvocêsviveram juntas?[atéaprimeirasaída decasa]

( ) ( ) anos (77 para não sabe; 88 para recusa)

A.Y2 Até os 15 anos com quem você morou a maior parte do tempo? (espontânea e múltipla)

01 ( ) mãe biológica

02 ( ) mãe adotiva

03 ( ) pai biológico

04 ( ) pai adotivo

05( ) avós (paternos e/oumaternos)

06 ( ) padastro/madastra

07 ( ) outros familiares

08 ( ) em instituições de apoio. Especificar:

09 ( ) outros:

77 ( ) não sabe/não lembra

88( )recusou-searesponder

A.Y 3Emalgum períododasuavida vocêmoroueminstituições (abrigo, orfanato, casasdeapoio)? (estimulada e única)

01 ( ) não morou

02 ( ) sim, morou por menos de 5 anos

03( ) sim, morou por 5 anos ou mais

77 ( ) não sabe/não lembra

88 ( ) recusou-se a responder

A.10 Quantosirmãos vocêtem? (irmãos vivos, incluindo de criação)

homens ( )( ) mulheres ( ) ( )

(00 para nenhum irmão/irmã; 77 para não sabe; 88 para recusa)

A.11 Com quem você mora? (espontânea e múltipla)

01 ( ) sozinha (pular para A13)

02 ( ) marido/companheiro

03 ( ) filho(a)(s)

04( )filho(a)(s) do parceiro atual

05 ( ) pai/padrasto

06 ( ) mãe/madrasta

07 ( ) irmão(ã)(s)

08 ( ) outros familiares

09 ( ) outrasituação. Especificar:

88 ( ) recusou-se aresponder

A.12 No total, são quantas pessoas incluindo você?

( ) ( ) (99, não se aplica se moradora de rua ou morando em instituição de apoio) 
A.13 Quando você precisa de ajuda ou tem algum problema, você pode contarcom (estimulada eúnica):

\begin{tabular}{|l|c|c|c|c|c|}
\hline \multicolumn{1}{|c|}{..pode contar com: } & sim, sempre & $\begin{array}{c}\text { sim, às } \\
\text { vezes }\end{array}$ & $\begin{array}{c}\text { não } \\
\text { (nunca) }\end{array}$ & $\begin{array}{c}\text { recusa } \\
\text { responder }\end{array}$ & não sabe \\
\hline a. vizinhos & $($ ) & $($ ) & $($ ) & $($ ) & $($ ) \\
\hline $\begin{array}{l}\text { b. parentes próximos (mãe, pai, } \\
\text { parceiro, filhos) }\end{array}$ & $($ ) & $($ ) & $($ ) & $($ ) & $($ ) \\
\hline c. outros parentes & $($ ) & $($ ) & $($ ) & $($ ) & $($ ) \\
\hline d. amigos e colegas & $($ ) & $($ ) & $($ ) & $($ ) & $($ ) \\
\hline $\begin{array}{l}\text { e. entidades assistenciais (ONG, } \\
\text { igreja, etc.) }\end{array}$ & $($ ) & $($ ) & $($ ) & $($ ) & $($ ) \\
\hline f. outro. Especificar: & $($ ) & $($ ) & $($ ) & $($ ) & $($ ) \\
\hline
\end{tabular}

\section{A.14 Em que estado você nasceu?}

1. ( )São Paulo (pular para A16)

2. () Acre (AC)

3. () Alagoas(AL)

4. ( ) Amapá(AP)

5. ( ) Amazonas (AM)

6. ()Bahia(BA)

7. ()Ceará(CE)

8. ( ) Distrito Federal(DF)

9. ( )Espírito Santo (ES)

10. ( ) Goiás (GO)

11. ( ) Maranhão (MA)

12. ( ) Mato Grosso(MT)

13. () Mato Grosso do Sul(MS)

14. ( ) Minas Gerais (MG)
15. ( ) Pará (PA)

16. ( ) Paraíba (PB)

17. ( ) Paraná (PR)

18. ( ) Pernambuco (PE)

19. ( ) Piauí (PI)

20. ( ) Rio de Janeiro (RJ)

21. ( ) Rio Grande do Norte(RN)

22. ( ) Rio Grande do Sul(RS)

23. ( ) Rondônia (RO)

24. ( ) Roraima (RR)

25. () Santa Catarina(SC)

26. ( ) Sergipe (SE)

27. ( ) Tocantins (TO)

28. () outropaís. Especificar:

A.15 Se de outro estado, quando você chegou em São Paulo para morar? (se morou em SP váriasvezes, considerar a data da última vez)
( ) ( ) ( ) ( ) Ano
(7777 para não sabe/não lembra)

A.16 Em que cidade você mora:

\begin{tabular}{|c|c|}
\hline ( ) São Paulo & 2. ( )Arujá \\
\hline 3. ( ) Barueri & 4. ( )Biritiba-Mirim \\
\hline 5. () Caieiras & 6. () Cajamar \\
\hline 7. ( ) Carapicuíba & 8. $\quad$ ()Cotia \\
\hline 9. $\quad$ ( ) Diadema & 10. () Embu das Artes \\
\hline 11. ( ) Embu-Guaçu & 12. ( ) Ferraz de Vasconcelos \\
\hline 13. ( ) Francisco Morato & 14. ( ) Franco da Rocha \\
\hline 15. ( ) Guararema & 16. ( ) Guarulhos \\
\hline 17. ( ) Itapevi & 18. ( ) Itapecerica da Serra \\
\hline 19. ( ) Itaquaquecetuba & 20. ( ) Jandira \\
\hline 21. ( ) Juquitiba & 22. ( )Mairiporã \\
\hline 23. ( )Mauá & 24. ( ) Mogi das Cruzes \\
\hline 25. ( ) Osasco & 26. ( ) Pirapora do Bom Jesus \\
\hline 27. ( ) Poá & 28. ( ) Ribeirão Pires \\
\hline 29. ( ) Rio Grande da Serra & 30. ( ) Salesópolis \\
\hline 31. ( ) Santa Isabel & 32. ( ) Santana de Parnaíba \\
\hline 33. ( ) Santo André & 34. ( ) São Bernardo do Campo \\
\hline 35. ( ) São Caetano do Sul & 36. ( ) São Lourenço da Serra \\
\hline 37. ( ) Suzano & 38. ( ) Taboão da Serra \\
\hline 39. ( ) Vargem Grande Paulista & 40. ( ) Outra. Especificar: \\
\hline
\end{tabular}


A.17 Em quebairro você mora nomunicípio de São Paulo? (Escreva onome do bairro)

A.18 Odomicílio onde você reside é:(estimulada eúnica)

01 ( ) próprio

02 ( ) alugado

03 ( ) cedido/emprestado

04 ( ) émoradora de rua

05 ( ) mora em abrigo/casa de apoio

06 ()outros. Especificar:

77 ( ) não sabe

88 ( ) recusou-se a responder 


\section{B. ESTUDO ETRABALHO}

Agora vamos conversar um pouco sobre estudo e trabalho.

B.1 Qualfoi a última série que você concluiu com aprovação?

(entrevistador classifica)

01 ( ) nunca frequentou aescola

02 ( ) ensinofundamental incompleto

03 ( ) ensino fundamental completo

04 ( ) ensino médio incompleto

05 ( ) ensino médio completo

06 ( ) ensinosuperior incompleto

07 ( ) ensino superior completo

08 ( ) pós-graduação

77 ( ) não sabe/não lembra

88() recusou-se a responder

Se alguma séria incompleta, preencher a B1a:

B.1a Série/ano concluído: ( ) ( )

ATENÇÃO: As questões BY1 a BY5 devem ser somente aplicadas para as MVHA entre 18 e 24 anos

B.Y1 Você está frequentando a escola atualmente?

01 ( ) sim

02 ( ) não

B.Y2 Você já repetiu de ano alguma vez? (Considerar somente até o ensino médio ou $2^{\circ}$ grau)

( ) ( ) número de vezes (00 se nuncarepetiu; 77 para não sabe/nãolembra;88 para recusa)

B.Y3 Alguma vezvocêprecisou interromper/parar osestudosporumanooumais? (paraaquelasquepararam de estudar, mas não concluíram os estudos, considerar a última vez)

( ) ( ) número de vezes (00 paraquem nunca parou; 77 para nãolembra; 88 para recusa)

B.Y4 Por que você interrompeu/parou os estudos (naúltima vez)? (espontânea eúnica)

01 ( ) ficou grávida

02( ) tinhaque cuidar da casa e/ou irmãos

03 ( ) precisavatrabalhar

04( )nãogostavadaescola/deestudar

05 ( ) se sentia discriminada na escola

06 ( ) ficou doente/foi internada

07( ) outromotivo. Especificar:

77 ( ) não sabe

88 ( ) recusou-se a responder

B.Y5 Que idade você tinha quando começou a trabalhar?

( ) ( ) anos (00 se nunca trabalhou; 77 para não lembra; 88 para recusa)

B.2 Atualmentevocêpossuialgumafontederendaprópria? (apenasoqueamulherrecebe, nãoincluirrenda de outraspessoas)

01 ( ) $\operatorname{sim}$

02 ( ) não (pular paraB6) 
B.2a Qual é a fonte de renda que você tem atualmente? (estimulada e múltipla)

02 ( ) próprio trabalho

03 ( ) auxílio doença

04 ( ) aposentadoria

05 ( ) pensão

06 ( ) algum tipo de benefício social

07 ( )Outrafonte.Especificar:

88( ) recusou-se a responder (pular para B5)

B.3 Nosúltimos 6 meses, vocêcontoucomessarenda regularmente,todososmeses?

01 ( ) sim

02 ( ) não

77 ( ) não sabe/não lembra

88() recusou-se a responder

B.4 Quala suarenda (média dos6 meses) por mês? R \$

B.5 Você diria que o dinheiro que você coloca em casa é maior, menor ou igual à contribuição de seu marido/companheiro? (estimulada eúnica)
01 ( ) maior
02 ( ) menor
03 ( )igual
77 ( ) não sabe
88 ( ) recusou-se a responder

[Se A18=5, pular para B7]

B.6 Qualé arenda total da sua casa no mês? R $\$$ [Se nenhuma, registre "0", se recusa, preencher 88]

B.7. Alguma vezna vida vocêpassou porperíodo sem domicílio fixo (casa/teto) porque nãotinha onde morar?

01 ( ) sim

02 ( ) não (pular paraB10)

77( ) não sabe/não lembra (pular paraB10)

88( )recusou-searesponder(pularparaB10)

B.8 Eonde você foi morar? (espontânea e múltipla)

01 ( ) quarto alugado, pensão, hotel

02 ( ) rua

03 ( )abrigoououtrainstituiçãoassistencial

04 ( ) casa de amigos (de favor)

05( ) casa deumafamília (defavor)

06 ( ) no próprio emprego

07( )outro.Especificar:

77 ( ) não sabe/nãolembra

88 ( ) recusou-se a responder

[Se MNVHA, pular para B10]

B.9 Quandoissoaconteceu?[estimulada eúnica]

01 ( ) antes do diagnóstico de HIV

02( ) depois do diagnóstico de HIV

03 ( ) ambos os momentos

77 ( ) não sabe/não lembra

88() recusou-se a responder 
B.10 Alguma vez na vida você já ficou um dia inteiro sem fazer pelo menos uma refeição completa porque não tinha dinheiro/não tinha o que comer?

01 ( ) sim

02 ( ) não (pular paraC1)

77( ) não sabe/nãolembra (pularparaC1)

88( )recusou-searesponder(pularparaC1)

[Se MNVHA, pular para C1]

B.11 Quandoisso aconteceu?[estimulada eúnica]

01 ( ) antes do diagnóstico de HIV

02( ) depois do diagnóstico de HIV

03 ( ) ambos os momentos

77 ( ) não sabe/não lembra

88() recusou-se a responder 
C. PARCERIAS AFETIVO-SEXUAIS

Agora vamos passar para algumas questões sobre a sua vida íntima e seus relacionamentos (namoros, casamentos e parceiros/as). Se você se sentir inibida ou não entender algumtermotécnico em qualquer pergunta, sinta-se à vontade para perguntar ou não responder.

Você já teve relações sexuais? (Seentrevistada mencionou terfilhos, não pergunte, apenas confirme a resposta)

01 ( ) sim

02 ( ) não

[Se C1=NÃO e MNVHA, encerrar a entrevista]

[SeC1=NÃOeMVHAeidade>=25,encerraraentrevista;seidade<25anos,continuecomCY1]

ATENÇÃO:AsquestõesCY1aCY7devemser aplicadassomenteparaMVHA virgensentre 18e24anos

C. Y1 Vocênãoteverelações sexuaisporque:(estimuladaeúnica)

01 ( ) tem/teve vontade mas nunca teve oportunidade

02 ( ) não encontrou o/a parceiro/a ideal/ adequado/a

03 ( ) pretende casar virgem

04 ( ) tem medo de infectar o parceiro

05 ( )outro. Especificar:

77 ( ) não sabe/ não lembra

88 ( ) recusou-se a responder

C.Y2 Você diriaqueser HIVpositivoéummotivoparanãoter iniciadoaindaasuavidasexual (estimuladae única):

01 ( ) muito importante

02 ( ) pouco importante

03 ( ) não é importante

77 ( ) não sabe/ não lembra

88( ) recusou-searesponder

C.Y 3 Quantos dos(as) seus(suas) amigos/as ou colegas também nunca tiveram relação sexual (estimuladae única)?

01 ( ) todos(as)

02 ( ) a maioria deles(as)

03 ( )algunsoupoucos

deles(as) 04 ( ) nenhum

deles(as)

77 ( ) não sabe/ não lembra

88( )recusou-searesponder

C.Y4 Quantos namorados / ficantes você já teve?

( ) ( ) (00 se nenhum; 77 para não sabe/não lembra; 88 para recusa)

C.Y 5 Já aconteceu de uma pessoa se recusar a namorar/ ficar com você porque você é soropositiva? (espontânea eúnica)

01 ( ) sim

02 ( ) não, nunca houve recusa desse tipo

03 ( ) não, porque nunca namorou/ficou com alguém

77 ( ) não sabe/ não lembra

88 () recusou-se a responder 
C.Y 6 Jáaconteceu de algum namorado / ficante romper com você porque você é soropositiva? (espontânea e única)

01 ( ) $\operatorname{sim}$

02 ( ) não, nunca houve recusa desse tipo

03 ( ) nãoporque nunca namorou/ficou com alguém

77 ( ) não sabe/ não lembra

88 ( ) recusou-se a responder

C.Y7Vocêsemasturba outocaseusórgãossexuais paraterprazer:(estimulada eúnica)

01 ( ) frequentemente

02() algumasvezes

03 ( ) raramente

04 ( ) nunca se masturbou

77 ( ) não sabe/ nãolembra

88 ( ) recusou-se a responder

[Após responder pergunta acima, pular para secão E (E1)]

Aproximadamente, quantos parceiros/as sexuais você já teve na vida? (Caso 'não sabe/não lembra', oferecer a alternativaC2a)

( ) ( ) ( ) ( )

C.2a Você diria que teve na vida:(estimulada eúnica)

01 ( ) 1 ou 2

02 ( ) 3 a 5

03 ( ) 6 a 10

04 ( ) 11 a 50

05 ( ) mais de 50

77 ( ) não sabe/ não lembra

88 () recusou-se a responder

Duranteasuavida sexual, suasrelaçõessexuaisforam: (estimulada eúnica)

01 ( ) só comhomens

02( ) mais frequentemente com homens, mas também com mulheres

03 ( ) igualmente com homens e mulheres

04 ( ) mais frequentemente com mulheres, mas também com homens

05( ) só com mulheres (agradecer e encerrar a entrevista)

77 ( ) não sabe/ não lembra

88() recusou-se a responder

\section{Primeira relação sexual}

Que idade você tinha na sua primeira relação sexual?
( ) ( ) anos
(77 para não sabe/não lembra; 88 para recusa)

Comrelação a sua primeira relação sexual, vocêdiria que:(estimulada eúnica)

01 ( ) queria ter aquela relação (pular para C7)

02( ) não queria mas concordou/consentiu (pular para C7)

03 ( ) foiforçada

77( ) nãosabe/nãolembra (pularpara C7)

88( )recusou-searesponder(pularparaC7)

Se forçada, com que idade aconteceu a primeira relação consentida? (

) ( ) anos

(77 para não sabe/não lembra; 88 para recusa) 
Apessoa com quem vocêteve asuaprimeira relação sexual(consentida) era:(estimulada eúnica)

01 ( ) namorado/a

02 ( ) pessoa com quem você "ficou" / "ficava"

03 ( ) marido ou companheiro/a (na época da $1^{a}$ relação)

04 ( ) amigo / colega

05 ( )outro. Especificar:

77( ) não sabe/não lembra (pular para C10)

88 ( ) recusou-se a responder (pular para C10)

Que idade tinha essa pessoa?
( ) ( ) anos
(77 para não sabe/não lembra; 88 para recusa)

Essapessoaerahomemoumulher?

01 ( ) homem

02( ) mulher(pularparaC13)

88( )recusou-se aresponder

\section{ATENÇÃO: As questões CY8 a CY11 devem ser aplicadas somente a MVHA entre 18 e 24 anos}

C.Y8 Qualeraaescolaridade desteparceironaépoca?(entrevistadora classifica) 01

( ) nunca frequentou a escola

02 ( ) ensinofundamental incompleto

03 ( ) ensino fundamental completo

04 ( ) ensino médio incompleto

05 ( ) ensino médio completo

06 ( ) ensino superior

incompleto 07 ( ) ensino

superior completo 08 ( ) pós-

graduação

77 ( ) não sabe/não lembra

88( )recusou-searesponder

C.Y9Quantotempodepois deiniciado orelacionamento vocêstiveram relações sexuais? (Registre apenasum campo: as semanas, se menos de 1 mês; os meses, se menos de 1 ano; e os anos, se 1 ano ou mais; os demais registre "00")
( ) ( ) semanas
( ) ( ) meses
( ) ( ) anos
(77 para não lembra; 88 para recusa)

Emvários momentos desta entrevista nós vamos conversar sobre formas e métodos de evitar filhos, ou seja tudoquevocêusaoufazparaevitarfilhos, inclusiveocoitointerrompido, acamisinhaeaesterilização.

C.Y10 Antes da primeira relação sexual, vocês conversaram sobre formas de evitar gravidez/filhos?

01 ( ) $\operatorname{sim}$

02 ( ) não

77 ( ) não sabe/ não lembra

88( )recusou-searesponder

C.Y11 Antes da primeira relação sexual, vocês conversaram sobre o uso da camisinha?

01 ( ) sim

02 ( ) não

77 ( ) não sabe/ não lembra

Nessaprimeirarelação, você(ouseuparceiro) fez/usoualgumacoisa paraevitar agravidez/filho, mesmo que tenha sido coito interrompido ou camisinha?

01 ( ) $\operatorname{sim}$

02 ( ) não (pular paraC12)

77 ( ) não sabe/ nãolembra (pularpara C12)

88( ) recusou-se a responder (pularpara C12) 
O que você (ou o seu parceiro) usou para evitar a gravidez/filho? (espontânea e múltipla)

01 ( ) camisinhamasculina

02 ( ) camisinha feminina

03 ( ) pílulaanticoncepcional

04 ( ) injeção

05 ( ) implante/anel vaginal hormonal/adesivo hormonal

06 ( ) DIU

07( ) pílula do dia seguinte/contracepção de emergência

08 ( ) coito interrompido/gozar fora

09 ( ) tabelinha

10 ( ) ligadura tubária

11 ( ) vasectomia

12( )outro.Especificar:

77 ( ) não sabe/ não lembra

88 ( ) recusou-se a responder

Vocês usaram camisinha masculina nessa primeira relação? (Se tiver mencionado a camisinha na resposta acima, não pergunte apenas confirme a resposta)

01 ( ) sim

02 ( ) não

77 ( ) não sabe/não lembra

88() recusou-se a responder

Alguma vez você já foi casada ou morou com um parceiro (homem)? Estamos considerando união/casamento ter morado com o/a parceiro/a na mesma casa por, no mínimo, um mês.

01 ( ) sim

02 ( ) não (pular paraC26)

88 ( ) recusou-se a responder (pular para C26)

Quantos casamentos/uniões você já teve?
( ) ( ) númerode uniões
(77 para não lembra; 88 para recusa)

\section{Parceiro da primeira união}

Agora vamos falar sobre sua primeira união/casamento.

O parceiro da sua primeira união é o mesmo da primeira relação sexual:

01 ( ) sim (pular para C17)

02 ( ) não

88 ( ) recusou-se a responder (pular para C26)

Qualo sexo do parceiro?

01 ( ) homem

02 ( ) mulher (pular para C26)

88 ( ) recusou-se a responder (pular para C26)

Qual era a escolaridade do parceiro quando foi morar com ele (última série concluída com aprovação)? (entrevistadora classifica)

01 ( ) nunca frequentou aescola

02 ( ) ensinofundamental incompleto

03 ( ) ensino fundamental completo

04 ( ) ensino médio incompleto

05 ( ) ensino médio completo

06 ( ) ensinosuperior incompleto

07 ( ) ensino superior completo

08 ( ) pós-graduação

77 ( ) não sabe/não lembra

88() recusou-se a responder 
Quantos anos tinha o seu parceiro quando foi morar com ele?
( ) ( ) anos completos
(77 para não lembra; 88 para recusa)

Quantosanos você tinha quando foi morar(casou) pela primeira vez com esse parceiro?
( ) ( ) anos completos
(77 para não lembra; 88 para recusa)

Vocês ainda estãojuntos?

01 ( ) sim (pularparaC33)

02 ( ) não

88 ( ) recusou-se a responder (pular para C23)

Oqueaconteceu naépoca?(estimulada eúnica)

01 ( ) vocês se separaram

02 ( ) ele morreu

88 ( ) recusou-se a responder

Quanto tempovocês ficaram juntos? (Registreapenas um campo: os meses, se menos de 1 ano; eos anos, se 1 ano ou mais; os demais registre "00")
( ) ( ) meses
( ) ( ) anos
(77 para não lembra; 88 para recusa)

Enquantoestavam juntos, você (ouseuparceiro) faziam/usavam alguma coisaparaevitar a gravidez/filho "Lembre-se que estamos considerando tudo que você usa ou faz para evitar filhos, inclusive o coito interrompido, a camisinha e a esterilização"??

01 ( ) sim

02 ( ) não (pular paraC25)

77 ( ) não lembra (pular para C25)

88 ( ) recusou-se a responder (pular para C25)

Oque você (ou o seuparceiro) usava? (espontânea e múltipla)

01 ( ) camisinhamasculina

02 ( ) camisinha feminina

03 ( ) pílulaanticoncepcional

04 ( ) injeção

05 ( ) implante/anel vaginal hormonal/adesivo hormonal

06 ( ) DIU

07( ) pílula do dia seguinte/contracepção de emergência

08 ( ) coito interrompido/gozar fora

09 ( ) tabelinha

10 ( ) ligadura tubária

11 ( ) vasectomia

12( )outro. Especificar:

77 ( ) não sabe/ não lembra

88 ( ) recusou-se a responder

Vocês usavam camisinha masculina nesse relacionamento? (estimulada eúnica)

01 ( ) sim, sempre

02 ( ) sim, às vezes

03 ( ) não, nunca usamos

$77($ ) não sabe/nãolembra

88 ( ) recusou-se a responder 


\section{Parceiro atual e outros parceiros}

Agoravamosfalarumpoucosobreoparceirocomquemvocêestáatualmente(marido, companheiro, namorado ou "ficante").

Atualmente, você mantém algum relacionamento que inclua sexo?)

01 ( ) $\operatorname{sim}$

02 ( ) não (pular para C33)

Essapessoaéhomemoumulher?

01 ( ) homem

02( ) mulher (encerrarquestionário)

88 ( ) recusou-se aresponder

Qualéaescolaridade doseuparceiro (última sérieconcluída comaprovação)?(entrevistador classifica)

01 ( ) nunca frequentou a escola

02( ) ensinofundamental incompleto

03 ( ) ensino fundamental completo

04 ( ) ensino médio incompleto

05 ( ) ensino médio completo

06 ( ) ensino superior incompleto

07 ( ) ensino superior completo

08 ( ) pós-graduação

77 ( ) não sabe/não lembra

88() recusou-se a responder

Há quanto tempo vocês estão juntos? (Registreapenas um campo: os meses, se menos de 1 ano; e os anos, se 1 ano ou mais; os demais registre "00")
( ) ( ) anos
( ) ( ) meses (77 para não lembra; 88 pararecusa)

Quantos anos tem o seu parceiro atualmente?
( ) ( ) anos completos
(77 para não lembra; 88 para recusa)

Vocês moram juntos?

01 ( ) sim (pularpara C33)

02 ( ) não

88 ( ) recusou-se a responder

Vocêconsideraoseuparceiroatual, seu:(estimuladaeúnica)

01 ( ) marido/companheiro

02 ( ) namorado/noivo

03 ( ) "ficante"

04 () amante/caso

05 ( )outro. Especificar:

77 ( ) não sabe/não lembra

88 ( ) recusou-se a responder

Você teverelaçãosexualnosúltimos 12 meses?

01 ( ) sim (pular para C35)

02 ( ) não

77 ( ) não sabe/ não lembra

88 () recusou-se a responder

Porque você está sem vida sexualmente ativa neste momento: (espontânea e múltipla)

01 ( ) não temvontade

02( )parceironãoquerterrelaçõessexuais

03 ( ) está sem parceiro 
04 ( ) sesentemenossedutora, atraente/temmedode ser rejeitada

05 ( ) não encontra uma pessoa que agrade

06 ( ) está muito cansada e sem saúde

07 ( ) parceiro está muito cansado e sem saúde

08 ( ) (válida apenas se MVHA) tem medo de infectar oparceiro

09( )outro.Especificar:

77 ( ) não sabe/ não lembra

88 ( ) recusou-se a responder/não lembra

Quantos parceiros/as sexuais você teve nos últimos 12 meses?
()()()()
(7777 para não lembra; 8888 para recusa)

Você manteveessesrelacionamentos aomesmotempo?(espontâneaeúnica)

01 ( ) sim, parcerias concomitantes/simultâneas

02() não, parcerias sequenciais

03 ( ) trabalhadora do sexo

77 ( ) não lembra

88 ( ) recusou-se a responder

[Somente se C36=1]: Se a mulher tem mais de 1 parceiro atual e são concomitantes, esclarecer que vamos conversarsobreoparceiro comquem a entrevistada mantem relacionamento hámaistempo

Atualmente você (ou seu parceiro) está fazendo/usando alguma coisa para evitar a gravidez/filho? "Lembre-se que estamos considerando tudo que você usa ou faz para evitar filhos, inclusive o coito interrompido, a camisinha e a esterilização"

01 ( ) $\operatorname{sim}$ (pularparaC39)

02 ( ) não

03( ) estágrávidanomomento(pular paraC41)

88( ) recusou-searesponder (pularparaC41)

Por que você (ou o seu parceiro) não está evitando gravidez atualmente? (espontânea e múltipla)

01 ( ) não tem relações sexuais atualmente

02 ( ) quer ter um filho/ está tentando engravidar

03 ( ) acabou de ter filho/ está amamentando

04() () vitater relaçõessexuaisemdiasarriscados

05 ( ) faz coitointerrompido

06 ( ) quando tem relação sexual usa preservativo

07 ( ) não gosta de usar método/nenhum método ébom/fazbem

08 ( ) é laqueada ou parceiro vasectomizado

09 ( ) é histerectomizada

10( ) está namenopausa

11 ( ) parceiro não deixa/não gosta que use

12 ( ) outrasituação. Especificar:

77 ( ) não sabe/nãolembra

88 ( ) recusou-se a responder

[Após responder pergunta acima, pular para C41]

Atualmente, o que você (ou o seu parceiro) usa para evitar filhos? (espontânea e múltipla)

01 ( ) camisinha masculina

02 ( ) camisinha feminina

03 ( ) pílulaanticoncepcional

04 ( ) injeção

05 ( ) implante/anel vaginal hormonal/adesivo hormonal

06 ( ) DIU

07( ) pílula do dia seguinte/contracepção de emergência

08 ( ) coito interrompido/gozar fora (pular para C41)

09 ( ) tabelinha (pular para C41) 
10 ( ) ligaduratubária (pular paraC41)

11 ( ) vasectomia (pular para C41)

12 ( )outro. Especificar:

77 ( ) não sabe/ não lembra (pular para C41)

(pularparaC41)

88 ( ) recusou-se a responder (pular para C41)

Aonde conseguiu (C40a:esse método) pelaúltima vez? (espontânea eúnica) (Válida para cada método assinaladona pergunta anterior)

\begin{tabular}{|l|c|c|c|c|}
\hline Método: & & & & $($ ) \\
\hline 01 comprou na farmácia & $($ ) & $($ ) & $($ ) & $($ ) \\
\hline 02 neste serviço de saúde & $($ ) & $($ ) & $($ ) & $($ ) \\
\hline 03 em outro serviço do SUS & $($ ) & $($ ) & $($ ) & $($ ) \\
\hline $\begin{array}{c}\text { 04 pegou gratuitamente na } \\
\text { farmácia Dose certa }\end{array}$ & $($ ) & $($ ) & $($ ) & $($ ) \\
\hline 05 pegou gratuitamente em ONG & $($ ) & $($ ) & $($ ) & $($ ) \\
\hline 06 Outro. Especificar: & $($ ) & $($ ) & $($ ) & $($ ) \\
\hline 77 não sabe/não lembra & $($ ) & $($ ) &
\end{tabular}

C41aC44 Vouleralgumasformasdefazer sexoegostaria quevocêmefalassese costumapraticá-lassempre, às vezes ou nunca? E vou também perguntar sobre uso da camisinha

(1-sempre; 2 - às vezes; 3 - nunca; 77 - não sabe/não lembra; 88- recusa responder)

\begin{tabular}{|l|l|l|l|l|l|l|l|l|l|l|l|}
\hline $\begin{array}{l}\text { C.41 Seu(s) parceiro(s) } \\
\text { faz(em) sexooral emvocê: }\end{array}$ & 1 & 2 & 3 & 77 & 88 & $\begin{array}{l}\text { C.41a Vocês usam alguma } \\
\text { proteção para evitar a } \\
\text { transmissãodoHIV:(sóMVHA) }\end{array}$ & 1 & 2 & 3 & 77 & 88 \\
\hline $\begin{array}{l}\text { C.42 Você faz sexo oral } \\
\text { no(s)parceiro(s): }\end{array}$ & 1 & 2 & 3 & 77 & 88 & C.42a Você usa camisinha: & 1 & 2 & 3 & 77 & 88 \\
\hline C.43Vocêfazsexovaginal: & 1 & 2 & 3 & 77 & 88 & C.43a Você usa camisinha: & 1 & 2 & 3 & 77 & 88 \\
\hline C.44 Você faz sexo anal: & 1 & 2 & 3 & 77 & 88 & C.44a Você usa camisinha: & 1 & 2 & 3 & 77 & 88 \\
\hline
\end{tabular}

C.45 Você disse que não faz sexo oral, vaginal ou anal, que tipo de prática sexual vocês fazem?

C.46 Emgeral, quem propõe ousoda camisinha?(espontânea eúnica)

01 ( ) você

02 ( ) o parceiro

03 ( ) ambos propõem

04 ( ) já tem acordo deusar

05 ( ) ninguém propõe o uso da camisinha

06 ( ) outrasituação. Especificar:

77 ( ) não lembra

88 ( ) recusou-se a responder

C.47 Algumavezseuparceiroatualsenegouausarcamisinhamasculinaquandovocêqueria?(espontâneae única)

01 ( ) $\operatorname{sim}$

02 ( ) não (pular paraC49)

77 ( ) não lembra (pular para C49)

88 ( ) recusou-se a responder (pular para C49) 
C.48 De que maneiras ele demonstrou para você que não aprovava o uso de camisinha? (espontânea e múltipla)

01( )falouquenãogostavada camisinha

02 ( ) gritou/ ficou com raiva

03 ( ) ameaçou bater

04 ( ) ameaçoute largar/pôrpra fora de casa

05 ( ) te bateu/agrediu

06 ( ) pegou ou destruiu o método

07 ( ) acusou você de serinfiel/de não ser umaboa mulher

08 ( ) riu de você/ não levou você a sério

09 ( ) disse que não era necessário

10( )dissequenãoteriasexocom camisinha

11 ( ) disse que era uma prova de amor

12 ( ) outras. Especificar:

77 ( ) não lembra

88 ( ) recusou-se a responder

[Se MVHA, após responder pergunta acima pular para C59]

\section{ATENÇÃO: As questões C49 a C58 referem-se apenas às MNVHA}

C.49 Oseuparceiro atual já fez teste para o HIV?

01 ( ) sim

02 ( ) não (pular para C52)

77( ) não sabe/nãolembra (pular para C52)

88( ) recusou-sea responder (pular para C52)

C.50 Você sabe quando foi a última vez que ele fez o teste para HIV (incluir teste feito na doação de sangue)?

01 ( ) não

02 ( ) há menos de um ano

03 ( ) há um ano ou mais

77( ) não sabe/nãolembra

88 ( ) recusou-se a responder

C.51 Você sabe qual o resultado do último teste para o HIV do seu parceiro?

01 ( ) sim, ele é HIV positivo

02( ) sim, eleéHIV negativo

03 ( ) não

77 ( ) não sabe/não lembra

88() recusou-se a responder

C.52 Você jáfezteste para HIV?

01 ( ) sim (pularparaC54)

02 ( ) não

77( ) não sabe/nãolembra (pular paraC59)

88( ) recusou-se a responder (pular para C59)

C.53 Qualo principal motivo para nunca ter feito o teste paraHIV? (espontânea eúnica)

01 ( ) não sabia que era bom/ recomendado

02( )nãosepercebeemrisco/ achaquenãoénecessárioparasi

03 ( ) nunca teve relações sexuais sem camisinha

04 ( ) confia no parceiro

05 ( ) medo do resultado

06 ( ) profissional de saúde nunca pediu para fazer

07 ( ) outros motivos. Especificar:

77 ( ) não sabe/nãolembra

88 ( ) recusou-se a responder

[Após responder pergunta acima, pular para C59] 
C.54 Aproximadamente quantas vezes você já fez esse teste?
( ) ( ) vezes
(77 para não lembra; 88 para recusa)

C.55 Quandofoiaúltimavezquevocêfezoteste?

01 ( ) há menos de um ano

02 ( ) há um ano ou mais

77( ) nãosabe/nãolembra

88 ( ) recusou-se a responder (pular para C59)

C.56 Qual foi o resultado desse último teste?

01 ()positivo (seMVHAfazertambém asquestõesespecíficas relacionadasaoHIV/AIDS)

02 ( ) negativo

77 ( ) não sabe/ não lembra

88 ( ) recusou-se a responder (pular para C59)

C.57 Onde você fez o último teste? (espontânea e única)

01( ) centrodetestagem eaconselhamento (CTA) ouserviços especializados de AIDS

02 ( ) unidade de saúde (SUS/público)

03 ( ) laboratório(privado/convênio)

04 ( ) hospital/ maternidade pública

05( ) hospital/clínica/maternidade particular (privado)

06 ( ) banco de sangue

07( ) outro. Especificar:

77 ( ) não sabe/não lembra

88 ( ) recusou-se a responder

C.58 Por quevocêfezessetestepara HIV?(espontâneaeúnica, entrevistadoraclassifica)

01 ( ) fez no pré-natal ou no parto

02 ( ) por iniciativa própria, por rotina/check-up

03 ( ) por iniciativa própria, porque teve relações sexuais desprotegidas

04 ( ) seu parceiro ficou doente/HIV

05 ( ) você ficou doente

06 ( ) médico pediu fora da gestação ou parto

07 ( ) porque estavam oferecendo o teste fora dos serviços de saúde (rua, shopping, etc)

08 ( ) outros motivos. Especificar:

77 ( ) não sabe/não lembra

88() recusou-se a responder

\section{Última relação sexual}

C.59 Há quanto tempo aconteceu sua última relação sexual? (Registre apenas um campo: se menos de 1 semana, registre "01"; semenosde 1 mêsregistreassemanas; semenosde 1 ano, registre osmeses; se 1 ano ou mais, registre os anos; nos demais campos registre "00")
( ) ( ) anos
( ) ( ) ( ) meses
( ) ( ) semanas

(77 para não sabe/não lembra; 88 para recusou-se a responder )

C.60 Quemeraesseparceiro?(espontânea eúnica,entrevistadoraclassifica)

01 ( ) seu parceiro atual (pular para C62)

02 ( ) outro parceiro fixo

03 ( ) um parceiro eventual/"ficante"

04 ( ) cliente

05( )outro/a. Especificar:

77 ( ) não sabe/nãolembra

88 ( ) recusou-se a responder (pular para C62) 
C.61 Seuparceiro naúltima relação era:

01 ( ) homem

02 ( ) mulher (pular para D1)

88 () recusou-se a responder

C.62 Nessarelaçãosexualvocê(ouseuparceiro)fez/usoualgumacoisaparaevitaragravidez/filho?

01 ( ) sim

02 ( ) não (pular para C64)

77 ( ) não lembra (pular para C64)

88 ( ) recusou-se a responder (pular para C64)

C.63 Oque você (ou o seu parceiro) usou? (espontânea e múltipla)

01 ( ) camisinhamasculina

02 ( ) camisinha feminina

03 ( ) pílulaanticoncepcional

04 ( ) injeção

05 ( ) implante/anel vaginal hormonal/adesivo hormonal

06 ( ) DIU

07( ) pílula do dia seguinte/contracepção de emergência

08 ( ) coito interrompido/gozar fora

09 ( ) tabelinha

10 ( ) ligadura tubária

11 ( ) vasectomia

12( )outro. Especificar:

77 ( ) não sabe/ não lembra

88 ( ) recusou-se a responder

C.64 Nessa última relação, vocês usaram camisinha masculina ou feminina? (Se tiver mencionado a camisinha na resposta acima, não pergunte, apenas confirme a resposta)

01 ( ) sim

02 ( ) não

77 ( ) não sabe/ não lembra

88 ( ) recusou-se a responder/não lembra 
D. GRAVIDEZ EDESDOBRAMENTOS

Vamos falar agora sobre gravidez e filhos.

Vocêjáengravidou alguma vezou estágrávida atualmente? Considere qualquer gravidez mesmo que não tenha resultado em nascido vivo.

01 ( ) sim

02 ( ) não (pular para E1 se MVHA, pular para F1 se MNVHA)

77( ) nãosabe/nãolembra (pular paraE1 seMVHA, pular paraF1seMNVHA)

88( ) recusou-se a responder (pular para E1 se MVHA, pular paraF1 se MNVHA)

D.2 Você está grávida no momento?

01 ( ) sim

02 ( ) não

77 ( ) não sabe/ não lembra

88 ( ) recusou-se a responder

D.3 Quantasvezes vocês engravidou? (contandoagravidezatual, casoaentrevistadaestejagrávida)
( ) ( ) vezes (77 para não sabe/não lembra; 88 para recusa)

D.4 De quantos parceiros você engravidou?

( ) ( ) número de parceiros (77 para não sabe/não lembra; 88 para recusa)

\section{M6: ENTREVISTADORA PREENCHA O QUADRO DE GESTAÇÕES}

TELA 4.1. Então, você teve, ao todo, ( ) ( ) gestações, certo?

TELA 4.2. E dessas ( ) gestações, ( ) ( ) foram interrompidas voluntariamente, ou seja, foram abortos provocados, certo?

Se MNVHA, pular para D5; se MVHA, continuar na Tela 4.3

TELA 4.3. Dessas ( ) gestações, ( ) ( ) foram antes do diagnóstico, certo?

TELA4.4. E ( ) ( ) gestações depois do diagnóstico (incluir gestação na qual diagnóstico foi dado), certo?

TELA 4.5. Desses ( ) abortos, ( ) ( ) foram provocados antes do diagnóstico, certo?

TELA 4.6. E ( ) ( ) abortos foram provocados depois do diagnóstico, certo?

ENTREVISTADORA: Preencher a seção seguinte sobre primeira gravidez (D5 a D17) 
Primeira gravidez (antes do diagnóstico) - respondem MVHA e MNVHA

Vamos conversar um pouco sobre a primeira vez que você engravidou, mesmo que essa gravidez tenha resultado emaborto.

D.5 Na sua primeira gravidez, que idade tem/tinha seu parceiro?

( ) ( ) anos completos (77 para não sabe/não lembra; 88 para recusa; registrar 99 "Não se aplica" se gravidez resultante de estupro ou se resultou em aborto realizado sob proteção da lei ou se outras perdas, que não aborto, até o 5ำ mês de gestação e ir para filtro D1)

D.6 Antes desaberqueestavagrávida,você:(estimulada eúnica)

01 ( ) estava tentando/querendo engravidar

02 ( ) não queria engravidar naquele momento

03 ( ) não pensava no assunto

77 ( ) não sabe/ não lembra

88 ( ) recusou-se a responder

D.7 No mês emquevocê descobriu que estava grávida, você (ou seuparceiro) estavafazendo/usando alguma coisa para evitar a gravidez/filho?

01 ( ) $\operatorname{sim}$

02 ( ) não (pular paraD10)

77 ( ) não lembra (pular para D10)

88 ( ) recusou-se a responder (pular para D10)

[Entrevistadora: Se estava tentando engravidar e não fazia nada para evitar, pular para D11]

D.8 Oque você(ou o seu parceiro) estava usando para evitarfilhos quando soubeque estava grávida? (espontânea emúltipla)

01 ( ) camisinha masculina

02 ( ) camisinha feminina

03( )pílulaanticoncepcional

04 ( ) injeção

05 ( ) implante/anel vaginal hormonal/adesivo hormonal

06 ( ) DIU

07( ) pílula do dia seguinte/contracepção de emergência

08 ( ) coito interrompido/gozar fora

09 ( ) tabelinha

10 ( ) ligadura tubária

11 ( ) vasectomia

12( )outro. Especificar:

77 ( ) não sabe/ não lembra

88 ( ) recusou-se a responder

D.9 Nasuaopinião, porqueestagravidezaconteceu? (espontâneaeúnica)

01 ( ) esqueceu de tomar a pílula

02 ( ) parou de tomar a pílula

03 ( )ficou doente(diarreia ouvômito), eusoumedicamentos

04 ( ) camisinha estourou ou saiu/escapuliu

05 ( ) não usou a camisinha em todas as relações

06 ( ) coito interrompido falhou / parceiro não fez o coito interrompido

07 ( ) falha do método utilizado

08( ) outromotivo. Especificar:

77 ( ) não sabe/ não lembra

88 ( ) recusou-se a responder

[Após responder pergunta acima, pular para D11] 
D.10 Quando você ficou grávida, por que você (ou o seu parceiro) não estava evitando filho? (espontânea e única)

01 ( ) não achava que fosse engravidar/ não se preocupava com isso

02 ( ) se engravidasse não teria problema

03 ( ) não tinha planejado ter relação sexual

04 ( ) havia interrompido ouso de métodorecentemente (menos de 1mês)

05 ( ) parceiro não gostava que usasse método

06 ( ) outrosmotivos. Especificar:

77 ( ) não sabe/ não lembra

88( )recusou-searesponder

D.11 No momento em que você descobriu que estava grávida, você diria que a situação financeira:

(estimulada eúnica)

01 ( ) estava boa, razoável

02 ( ) estava um poucoapertada

03 ( ) estava muito difícil

77 ( ) não sabe/não lembra

88 () recusou-se a responder

D.12 Nomomentoemquevocêdescobriuqueestavagrávida,arelaçãocomseuparceiro:(estimuladae única)

01 ( ) estava iniciando

02 ( ) estava estável

03( ) estava instável/emcrise/terminando

04 ( ) não tinha um parceiro fixo

77 ( ) não sabe/não lembra

88() recusou-se a responder

D.13 Vocêsofreuviolênciafísica porpartede seu(algum) parceiroenquantoestavagrávida?

01 ( ) sim

02 ( ) não

77 ( ) não sabe/ não lembra

88 () recusou-se a responder

Tela1.Filtro_X1:ENTREVISTADORA, ESSAGRAVIDEZ(VERLINHAH1 DOQUADRO), FOIINTERROMPIDA? 01( )sim,abortoprovocado

02 ( ) sim, abortoespontâneo

03 ( ) não

[Entrevistadora: Se teve aborto provocado ir para Filtro D1]

D.14 Você fez ou tomou algo para tentar interromper a gravidez?

01 ( ) $\operatorname{sim}$

02 ( ) não (pular para D15)

77 ( ) não sabe/ não lembra

88() recusou-se a responder

D14a. O que você fez ou tomou para tentar interromper a gravidez?

\section{[Se teve aborto espontâneo, pular para D16]}

D.15 Em se tratando da decisão de levar a gravidez adiante: (estimulada e única)

01( )vocêeoseuparceiro estavamdeacordocomoprosseguimentodagravidez

02 ( ) você desejava prosseguir com a gravidez, mas seu parceiro não

03 ( ) seuparceiro desejava queagravidez prosseguisse, masvocê não

04 ( ) seu parceiro a deixou escolher (se prosseguia ou não)

05 ( ) seu parceiro não foi informado da gravidez 
06 ( )outro. Especificar:

77 ( ) não sabe/ não lembra

88 ( ) recusou-se a responder

[Entrevistadora: Se grávida e primeira gestação, pular parafiltro D1; se grávida e não é a primeira gestação, seguir paraD16]

\section{Método após a $1^{\text {a }}$ gravidez}

D.16 Até um ano depois do término dessa gravidez, você diria que: (estimulada e única)

01 ( ) passou a usar algum (outro) método para evitar a gravidez

02( ) continuouusandoomesmométododeantesda gravidez

03 ( ) não usou nenhum método (pular para Filtro D1)

04( )nãoteverelaçãosexualnesseperíodo(atéumanoapósoparto)(pularparaFiltro D1)

05( ) outra situação Especificar:

77 ( ) não sabe/não lembra

88 ( ) recusou-se a responder (pular para Filtro D1)

D.17 Qualmétodo você usava para evitargravidez:(espontânea emúltipla)

01 ( ) camisinhamasculina

02 ( ) camisinha feminina

03 ( ) pílulaanticoncepcional

04 ( ) injeção

05 ( ) implante/anel vaginal hormonal/adesivo hormonal

06 ( ) DIU

07( ) pílula do dia seguinte/contracepção de emergência

08 ( ) coito interrompido/gozar fora

09 ( ) tabelinha

10 ( ) ligadura tubária

11 ( ) vasectomia

12( )outro. Especificar:

77 ( ) não sabe/nãolembra

88 ( ) recusou-se a responder

Filtro_D1:

Se MVHA:

\begin{tabular}{|c|c|c|c|c|}
\hline $\begin{array}{l}\text { Número de } \\
\text { gestações }\end{array}$ & $\begin{array}{l}\text { Antes ou após/no } \\
\text { diagnóstico }\end{array}$ & $\begin{array}{l}\text { Relato de aborto } \\
\text { provocado }\end{array}$ & $\begin{array}{l}1^{\circ} \text { aborto éa } 1^{\text {a }} \\
\text { gravidez ou } 1^{\mathrm{a}} \\
\text { gravidez após/no } \\
\text { diagnóstico? }\end{array}$ & Ir para \\
\hline \multirow{3}{*}{ Apenas 1} & \multirow{3}{*}{ Antes } & \multirow{2}{*}{ Sim } & Sim, $1^{\text {a }}$ gravidez & D63 (1ํaborto) \\
\hline & & & Não & D55 (1ํaborto) \\
\hline & & Não & $\longrightarrow$ & E1 (diagnóstico) \\
\hline \multirow{2}{*}{$\begin{array}{l}\text { Mais de } 1 \\
\text { gestação }\end{array}$} & Depois/no & Com ou sem relato & & $\begin{array}{c}\text { D18 (1 } 1^{\text {a }} \text { gravidez } \\
\text { após/no diagnóstico) }\end{array}$ \\
\hline & Todas antes & Com ou sem relato & & D37 (última gravidez) \\
\hline
\end{tabular}

Se MNVHA:

\begin{tabular}{|c|c|c|c|}
\hline $\begin{array}{l}\text { Número de } \\
\text { gestações }\end{array}$ & $\begin{array}{c}\text { Relato de aborto } \\
\text { provocado }\end{array}$ & $\begin{array}{c}1^{\circ} \text { aborto é a } 1^{\mathrm{a}} \\
\text { gravidez? }\end{array}$ & Ir para \\
\hline \multirow{3}{*}{ Apenas 1} & \multirow{2}{*}{ Sim } & Sim, $1^{\text {a }}$ gravidez & D63 (1ํaborto) \\
\hline & & Não & D55 (1ํaborto) \\
\hline & Não & & $\begin{array}{l}\mathrm{F} 1 \text { (planejamento } \\
\text { reprodutivo) }\end{array}$ \\
\hline $\begin{array}{l}\text { Mais de } 1 \\
\text { gestação }\end{array}$ & Com ou sem relato & & D37 (última gravidez) \\
\hline
\end{tabular}




\section{Primeira gravidezapós odiagnóstico ou gravidez em que ficou sabendo do diagnóstico}

Agoravamosconversarumpoucosobreaprimeiravezquevocêengravidouapósodiagnósticode HIV, mesmo que essa gravidez tenha resultado em aborto.

Tela 2. Filtro_Y1: ENTREVISTADORA, ODIAGNÓSTICO FOI DADO NESSA GRAVIDEZ(VER COLUNA B DO QUADRO)?

01( )sim,nagravidez

02 ( ) sim, no parto

03 ( ) não

D.18 Nessa gravidez, que idade tinha seu parceiro?

( ) ( ) anos completos

(77 para não sabe/não lembra e 88 para recusa; registrar 99 "Nãoseaplica" segravidezresultantedeestuproouseresultouemabortorealizadosobproteçãodaleiou se outrasperdas, que nãoaborto, atéo 5ำ ês degestação). Se não seaplica, pularpara Filtro D2.

D.19 Antesdesaberqueestavagrávida,você:(estimuladaeúnica)

01 ( ) estava tentando/querendo engravidar

02( ) nãoqueriaengravidar naquelemomento

03 ( ) não pensava no assunto

77 ( ) não sabe/não lembra

88( )recusou-searesponder

[Se não queria engravidar ou não pensava no assunto( $(D 19=2$ ou 3 ou 77) e o diagnóstico não foi dado nessa gravidez (filtro y1=3), pular para D22]

[Se não queria engravidar ou não pensava no assunto ( $D 19=20 u 3$ ou 77 ) e o diagnóstico foi dado na gravidez ou no parto (filtro_y1=1 ou 2), pular para D23]

[Se estava tentando engravidar (D19=1) e diagnóstico foi dado nessa gravidez ou no parto (filtro y1=1 ou 2), pular para D23]

D.20 Antes deficargrávida, vocêcontouparaomédico oualguém noserviço desaúdequequeriaengravidar?

01 ( ) sim

02 ( ) não (pular para D22)

77( ) não sabe/ nãolembra (pular para D22)

88( )recusou-searesponder(pularparaD22)

D.21 Oqueaconteceu quandovocêcontou?(estimuladaeúnica)

01 ( ) foi aconselhada a não engravidar

02 ( ) não se opuseram à gravidez efoi acompanhada pelo médico para que você engravidasse de maneira segura

03 ( ) não se opuseram à gravidez mas engravidou sem orientação ou ajuda profissional

04 ( ) não comentaram/orientaram nada

05 ( ) outrasituação. Especificar:

77 ( ) não sabe/ não lembra

88 ( ) recusou-se a responder

[Se diagnóstico foi dado nesta gravidez (filtro Y1=1), pular para D23]

D.22 Quandovocêengravidou asuacargaviral estava:(estimulada eúnica)

01 ( ) alta

02 ( ) baixa

03 ( ) indetectável

04 ( )outro. Especificar:

77 ( ) não sabe/ não lembra

88 ( ) recusou-se a responder 
D.23 No mês emquevocê descobriuque estavagrávida, você(ou seu parceiro) estavafazendo/usando alguma coisa para evitar a gravidez/filho?

01 ( ) sim

02 ( ) não (pular paraD26)

77 ( ) não lembra (pular para D26)

88 ( ) recusou-se a responder (pular para D26)

(Se estava tentando engravidar (D19=1) e não fazia nada para evitar (D23=2), pular para D27)

D.24 Oque você(ou o seu parceiro) estava usando para evitarfilhos quando soube que estavagrávida? (espontânea emúltipla)

01 ( ) camisinha masculina

02 ( ) camisinha feminina

03( )pílulaanticoncepcional

04 ( ) injeção

05 ( ) implante/anel vaginal hormonal/adesivo hormonal

06 ( ) DIU

07( ) pílula do dia seguinte/contracepção de emergência

08 ( ) coito interrompido/gozar fora

09 ( ) tabelinha

10 ( ) ligadura tubária

11 ( ) vasectomia

12( )outro. Especificar:

77 ( ) não sabe/ não lembra

88 ( ) recusou-se a responder

D.25 Nasuaopinião, porqueestagravidez aconteceu? (espontâneaeúnica)

01 ( ) esqueceu de tomar a pílula

02 ( ) parou de tomar a pílula

03 ( ) ficou doente(diarreia ou vômito) e usoumedicamentos

04 ( ) camisinha estourou ou saiu/escapuliu

05 ( ) não usou a camisinha em todas as relações

06 ( ) coito interrompido falhou/parceiro nãofez o coito interrompido

07 ( ) falha do método utilizado

08( ) outromotivo. Especificar:

77 ( ) não sabe/ não lembra

88 ( ) recusou-se a responder

[Após responder pergunta acima, pular para D27]

D.26 Quando você ficou grávida, por que você (ou seu parceiro) não estava evitando filho? (espontânea e única)

01( ) não achava que fosse engravidar/ não se preocupava com isso

02 ( ) se engravidasse não teria problema

03 ( ) não tinha planejado ter relação sexual

04 ( ) havia interrompido ouso de métodorecentemente (menos de 1mês)

05 ( ) parceiro não gostava que usasse método

06 ( ) outrosmotivos. Especificar:

77 ( ) não sabe/ não lembra

88( )recusou-searesponder

D.27 No momento em que você descobriu que estava grávida, você diria que a situação financeira:

(estimulada eúnica)

01 ( ) estava boa, razoável

02 ( ) estava um poucoapertada

03 ( ) estava muito difícil

77 ( ) não sabe/ não lembra

88() recusou-se a responder 
D.28 Nomomentoemquevocêdescobriuqueestavagrávida,arelaçãocomseuparceiro:(estimuladae única)

01 ( ) estava iniciando

02 ( ) estava estável

03( ) estava instável/em crise/terminando

04 ( ) não tinha um parceiro fixo

77 ( ) não sabe/não lembra

88() recusou-se a responder

D.29 Você sofreu violênciafísica porparte de seu(algum) parceiro enquanto estava grávida?

01 ( ) sim

02 ( ) não

77 ( ) não sabe/ não lembra

88() recusou-se a responder

Tela 3. Filtro_X2: ENTREVISTADOR, ESSA GRAVIDEZ(PRIMEIRA GRAVIDEZ APÓS DIAGNÓSTICO) FOI

INTERROMPIDA?

01( ) sim,abortoprovocado

02( ) sim, aborto espontâneo

03 ( ) não

[Se teve aborto provocado, pular para filtro D2]

D.30 Você fez ou tomou algo para tentar interromper a gravidez?

01 ( ) $\operatorname{sim}$

02 ( ) não (pular para D31)

77 ( ) não sabe/ não lembra

88() recusou-se a responder

D.30a O que você fez ou tomou para tentar interromper a gravidez?

[Se teve aborto espontâneo, pular para D35]

D.31 Em se tratando da decisão de levar a gravidez adiante: (estimulada e única)

01 ( )vocêeoseuparceiroestavamdeacordocomoprosseguimentodagravidez

02 ( ) você desejava prosseguir com a gravidez, mas seu parceiro não

03( ) seuparceiro desejava queagravidez prosseguisse, masvocê não

04 ( ) seu parceiro a deixou escolher (se prosseguia ou não)

05 ( ) seu parceiro não foi informado da gravidez

06 ( )outro. Especificar:

77 ( ) não sabe/ nãolembra

88 ( ) recusou-se a responder

D.32 Durante estagravidez você utiliza/utilizoualgum remédio para o HIV/antirretroviral?(Verificarse diagnóstico não aconteceu no parto, nesse caso assinalar a resposta 3)

01 ( ) sim

02 ( ) não

03( ) nãoporquefoidiagnosticadaapenasnoparto

77 ( ) não sabe/ não lembra

88 ( ) recusou-se a responder

[Se diagnóstico foi no parto, pular para D34]

D.33 Enomomentodessepartorecebeumedicação parao HIV? (Nãoaplicável segrávidaeessagravidez é a primeira depois do diagnóstico)

01 ( ) $\operatorname{sim}$

02 ( ) não

77 ( ) não sabe/ não lembra

88 () recusou-se a responder

99 ( ) não se aplica 
D.34 Eo seubebê,tomou oremédio para oHIV? (Nãoaplicável se grávida ou se criança nasceu morta)

01 ( ) $\operatorname{sim}$

02 ( ) não

77 ( ) não sabe/ não lembra

88 ( ) recusou-se a responder

99 ( ) não se aplica

[Se grávida e teve apenas uma gestação após/durante o diagnóstico, pular para filtro D2]

[Se grávida e teve mais de uma gestação após/durante o diagnóstico, seguir para D35]

\section{Método após a $\mathbf{1}^{\mathrm{a}}$ gravidez depois do diagnóstico}

D.35 Até um ano depois do término dessa gravidez, você diria que: (estimulada e única)

01 ( ) passou a usar algum (outro) método para evitar a gravidez

02( )continuouusandoomesmométododeantesda gravidez

03 ( ) não usou nenhum método (pular para Filtro_D2)

04( ) nãoteve relaçãosexual nesse período (até um ano após oparto) (pular para Filtro_D2)

05 ( ) outrasituação Especificar:

77 ( ) não sabe/não lembra (pular para Filtro_D2)

88 ( ) recusou-se a responder (pular para Filtro_D2)

D.36 Qualmétodo vocêusava para evitargravidez:(espontânea emúltipla)

01 ( ) camisinhamasculina

02 ( ) camisinha feminina

03 ( ) pílulaanticoncepcional

04 ( ) injeção

05 ( ) implante/anel vaginal hormonal/adesivo hormonal

06 ( ) DIU

07( ) pílula do dia seguinte/contracepção de emergência

08 ( ) coito interrompido/gozar fora

09 ( ) tabelinha

10 ( ) ligadura tubária

11 ( ) vasectomia

12( )outro. Especificar:

77 ( ) não sabe/nãolembra

88 ( ) recusou-se a responder

Filtro_D2:

\begin{tabular}{|c|c|c|c|c|}
\hline $\begin{array}{l}\text { Número de } \\
\text { gestações }\end{array}$ & $\begin{array}{l}\text { Relato de } \\
\text { aborto } \\
\text { provocado }\end{array}$ & $\begin{array}{c}19 \text { (ou único) } \\
\text { aborto antes ou } \\
\text { apósdiagnóstico? }\end{array}$ & $\begin{array}{c}1^{0} \text { aborto é a } 1^{\mathrm{a}} \\
\text { gravidez ou } 1^{\mathrm{a}} \\
\text { gravidezapós/no } \\
\text { diagnóstico? }\end{array}$ & Ir para \\
\hline \multirow{5}{*}{$\begin{array}{l}\text { Não teve mais } \\
\text { gestação }\end{array}$} & \multirow{4}{*}{ Sim } & \multirow{2}{*}{ Antes } & Sim, $1^{\text {a }}$ gravidez & D63 (1ㅇaborto) \\
\hline & & & Não & D55 (1 ${ }^{\circ}$ aborto) \\
\hline & & \multirow{2}{*}{ Depois } & $\begin{array}{c}\text { Sim, } 1^{a} \text { gravidez } \\
\text { após/no diagnóstico }\end{array}$ & $\begin{array}{c}\text { D84 (1ํaborto após } \\
\text { diagnóstico) }\end{array}$ \\
\hline & & & Não & $\begin{array}{c}\text { D75 (1ํaborto após } \\
\text { diagnóstico) }\end{array}$ \\
\hline & Não & & $\rightarrow$ & E1 (diagnóstico) \\
\hline $\begin{array}{l}\text { Mais de } 1 \\
\text { gestação }\end{array}$ & $\begin{array}{l}\text { Com ou sem } \\
\text { relato }\end{array}$ & & & D37 (última gravidez) \\
\hline
\end{tabular}




\section{Última gravidez - respondem MVHA e MNVHA}

Agora vamos falar da última vez que você engravidou, mesmo que essa gravidez tenha resultado em aborto ou que você ainda esteja grávida nesse momento.

D.37 Que idade tem/tinha seu parceiro nessa última gravidez?
( ) ( ) anos completos
(77 para não sabe/não lembra; 88 para recusa; registrar 99 "Não

se aplica" se gravidez resultante de estupro ou seresultou em aborto realizado sobproteçãoda lei ou seoutras perdas, que não aborto, até o 5ํำês de gestação). Se não se aplica, pular para Filtro D3.

D.38 Antes de saber que estava grávida, você: (estimulada e única)

01 ( )estavatentando/querendo engravidar (pularpara D42se MVHAe nãotevegestaçãoapós

diagnóstico)

02 ( ) não queria engravidar naquele momento (pular para D41)

03 ( ) não pensava no assunto (pular para D41)

77 ( ) não sabe/ não lembra

88() recusou-se a responder

[Se MNVHA, pular para D42]

D.39 Antes deficar grávida, você contou paraseumédicoou para alguém noserviçode saúdequequeria engravidar?

01 ( ) $\operatorname{sim}$

02 ( ) não (pular paraD41)

77( ) não sabe/nãolembra (pularpara D41)

88( )recusou-searesponder(pularparaD41)

D.40 Oqueaconteceu quandovocêcontou?(estimuladaeúnica)

01 ( ) foi aconselhada a não engravidar

02 ( ) não se opuseram à gravidez e foi acompanhada pelo médico para que você engravidasse de maneira segura

03 ( ) não se opuseram à gravidez mas engravidou sem orientação ou ajuda profissional

04 ( ) não comentaram/orientaram nada

05 ( ) outrasituação. Especificar:

77 ( ) não sabe/ não lembra

88 ( ) recusou-se a responder

[Se MVHA e não teve gestação após diagnóstico, pular para D42]

D.41 Quandovocêengravidou asua cargaviral estava:(estimulada eúnica)

01 ( ) alta

02 ( ) baixa

03 ( ) indetectável

04 ( ) outro:

77 ( ) não sabe/ não lembra

88 ( ) recusou-se a responder

D.42 Nomêsemquevocêdescobriu queestavagrávida, você(seuparceiro) estavafazendo/usando alguma coisa para evitar a gravidez/filho?

01 ( ) sim

02 ( ) não (pular paraD45)

77 ( ) não lembra (pular para D45)

88 ( ) recusou-se a responder (pular para D45)

[Se estava tentando engravidar (D38=1) e não fazia nada para evitar (D42=2), pular para D46] 
D.43 Oque você(ou o seu parceiro) estava usando paraevitar filhos quando soube que estavagrávida? (espontânea emúltipla)

01 ( ) camisinha masculina

02 ( ) camisinha feminina

03( )pílulaanticoncepcional

04 ( ) injeção

05 ( ) implante/anel vaginal hormonal/adesivo hormonal

06 ( ) DIU

07( ) pílula do dia seguinte/contracepção de emergência

08 ( ) coito interrompido/gozar fora

09 ( ) tabelinha

10 ( ) ligadura tubária

11 ( ) vasectomia

12( )outro. Especificar:

77 ( ) não sabe/ não lembra

88 ( ) recusou-se a responder

D.44 Nasuaopinião, porqueestagravidez aconteceu? (espontâneaeúnica)

01 ( ) esqueceu de tomar a pílula

02 ( ) parou de tomar a pílula

03 ( )ficou doente(diarreia ouvômito), eusoumedicamentos

04 ( ) camisinha estourou ou saiu/escapuliu

05 ( ) não usou a camisinha em todas as relações

06 ( ) coito interrompido falhou/parceiro não fezo coito interrompido

07 ( ) falha do método utilizado

08( ) outromotivo. Especificar:

77 ( ) não sabe/ não lembra

88 ( ) recusou-se a responder

\section{[Após responder pergunta acima pular para D46]}

D.45 Quandovocêficougrávida, porquevocê (oseu parceiro) nãoestava evitando filho? (espontâneae única)

01 ( ) não achava que fosse engravidar/ não se preocupava com isso

02 ( ) se engravidasse não teria problema

03 ( ) não tinha planejado ter relação sexual

04 ( ) havia interrompido ouso de métodorecentemente (menos de 1mês)

05 ( ) parceiro não gostava que usasse método

06 ( ) outrosmotivos. Especificar:

77 ( ) não sabe/ não lembra

88( )recusou-searesponder

D.46 No momento em que você descobriu que estava grávida, você diria que a situação financeira:

(estimulada eúnica)

01 ( ) estava boa, razoável

02 ( ) estava um poucoapertada

03 ( ) estava muito difícil

77 ( ) não sabe/ não lembra

88() recusou-se a responder

D.47 Nomomentoemquevocêdescobriuqueestavagrávida,arelaçãocomseuparceiro:(estimuladae única)

01 ( ) estava iniciando

02 ( ) estava estável

03( ) estava instável/ em crise/terminando

04 ( ) não tinha um parceiro fixo

77 ( ) não sabe/não lembra

88() recusou-se a responder 
D.48 Vocêsofreu violênciafísica porparte de seu(algum) parceiro enquanto estava grávida?

01 ( ) sim

02 ( ) não

77 ( ) não sabe/ não lembra

88 () recusou-se a responder

Tela 4. ENTREVISTADOR, ESSA GRAVIDEZ (ÚLTIMA GRAVIDEZ) FOI INTERROMPIDA?

01 ( ) sim, aborto provocado

02( ) sim, abortoespontâneo

03 ( ) não

[Se teve aborto provocado, pular para Filtro D3]

D.49 Você fez ou tomou algo para tentar interromper essa gestação?

01 ( ) sim

02 ( ) não (pular para D50)

77( ) não sabe/ nãolembra (pularpara D50)

88( )recusou-searesponder(pularparaD50)

D49A. O que você fez ou tomou para tentar interromper essa gestação?

[Se teve aborto espontâneo nessa gravidez, pular para D53]

D.50 Em se tratando da decisão de levar a gravidez adiante: (estimulada e única)

01 ( ) você e seu parceiro estavam de acordo com o prosseguimento da gravidez

02 ( ) você desejava prosseguir com a gravidez, mas seu parceiro não

03 ( ) seuparceiro desejava queagravidez prosseguisse, masvocê não

04 ( ) seu parceiro a deixou escolher (se prosseguia ou não)

05 ( ) seu parceiro não foi informado da gravidez

06 ( ) outro. Especificar:

77 ( ) não sabe/ não lembra

88 ( ) recusou-se a responder

[Se MNVHA, pular para D53]

[Se MVHA e não teve gestação após diagnóstico, pular para D53]

D.51 Durante esta gravidez você utilizou/está utilizando algum remédio para o HIV/antirretroviral?
01 ( ) sim
02 ( ) não
77 ( ) não sabe/ não lembra
88() recusou-se a responder

[Se teve aborto espontâneo nessa gestação, pular para D53]

D.52 E no momento do parto recebeu medicação para o HIV? (Não aplicável se está grávida)

01 ( ) $\operatorname{sim}$

02 ( ) não

77 ( ) não sabe/ não lembra

88( )recusou-searesponder

99 ( ) não se aplica

D. 2a Eoseubebê,tomouoremédioparaoHIV?(Nãoaplicávelseestágrávidaousecriançanasceumorta)

01 ( ) sim

02 ( ) não

03( )outro. Especificar:

77 ( ) não sabe/ não lembra

88() recusou-se a responder

99 ( ) não se aplica

[Se grávida, pular para filtro D3] 


\section{Método após a última gravidez}

D.53 Até um ano depois do término dessa gestação, você diria que: (estimulada e única)

01 ( ) passou a usar algum (outro) método para evitar a gravidez

02( )continuouusandoomesmométododeantesda gravidez

03 ( ) não usou nenhum método (pular para Filtro D3)

04( ) não teverelação sexual nesse período(até umano apóso parto) (pular para Filtro D3)

05 ( ) outrasituação Especificar:

77 ( ) não sabe/não lembra (pular para Filtro D3)

88 ( ) recusou-se a responder (pular para Filtro D3)

D.54 Qualmétodo você usava para evitar gravidez: (espontânea e múltipla)

01 ( ) camisinhamasculina

02 ( ) camisinha feminina

03 ( ) pílulaanticoncepcional

04 ( ) injeção

05 ( ) implante/anel vaginal hormonal/adesivo hormonal

06 ( ) DIU

07 ( ) pílula do dia seguinte/contracepção de emergência

08 ( ) coito interrompido/gozar fora

09 ( ) tabelinha

10 ( ) ligadura tubária

11 ( ) vasectomia

12( )outro. Especificar:

77 ( ) não sabe/nãolembra

88 ( ) recusou-se a responder

Filtro_D3:

\begin{tabular}{|c|c|c|c|c|}
\hline $\begin{array}{l}\text { Tipo de } \\
\text { grupo }\end{array}$ & $\begin{array}{l}\text { Relato de } \\
\text { aborto } \\
\text { provocado }\end{array}$ & $\begin{array}{l}\text { 19(ouúnico) aborto } \\
\text { antes ou após } \\
\text { diagnóstico? }\end{array}$ & $\begin{array}{c}1^{\circ} \text { abortoéa } 1^{a} \text { gravidez } \\
\text { ou } 1^{1} \text { gravidez após/no } \\
\text { diagnóstico? }\end{array}$ & Ir para \\
\hline \multirow{5}{*}{ MVHA } & \multirow{4}{*}{ Sim } & \multirow{2}{*}{ Antes } & Sim, $1^{\text {a }}$ gravidez & D63 (1ํaborto) \\
\hline & & & Não & D55 (1ํaborto) \\
\hline & & \multirow{2}{*}{ Depois } & $\begin{array}{c}\text { Sim, } 1^{\text {a }} \text { gravidez após/no } \\
\text { diagnóstico }\end{array}$ & $\begin{array}{l}\text { D84 (10 aborto após } \\
\text { diagnóstico) }\end{array}$ \\
\hline & & & Não & $\begin{array}{c}\text { D75 (1ํaborto após } \\
\text { diagnóstico) }\end{array}$ \\
\hline & Não & & $\longrightarrow$ & E1 (diagnóstico) \\
\hline \multirow{3}{*}{ MNVHA } & \multirow{2}{*}{ Sim } & & Sim, $1^{\text {a }}$ gravidez & D63 (1ํaborto) \\
\hline & & & Não & D55 (1ํaborto) \\
\hline & Não & & & $\begin{array}{l}\mathrm{F} 1 \text { (planejamento } \\
\text { reprodutivo) }\end{array}$ \\
\hline
\end{tabular}

\section{Sobre o primeiro aborto provocado (antes do diagnóstico)}

Vamos conversar um pouco mais sobre sua experiência do primeiroaborto

D.55 Que idade tinha o seu parceiro nessa gravidez?

( ) ( ) anos completos (77 para não sabe/não lembra; 88 para recusa)

D.56 Nomêsem quevocê descobriuque estavagrávida,você(ouseuparceiro) estavafazendo/usando alguma coisa para evitar a gravidez/filho?

01 ( ) sim

02 ( ) não (pular paraD59)

77 ( ) não lembra (pular para D59)

88 ( ) recusou-se a responder (pular para D59) 
D.57 Oque você(ou o seu parceiro) estava usando para evitar filhos quando soubeque estavagrávida? (espontânea emúltipla)

01 ( ) camisinha masculina

02 ( ) camisinha feminina

03( )pílulaanticoncepcional

04 ( ) injeção

05 ( ) implante/anel vaginal hormonal/adesivo hormonal

06 ( ) DIU

07( ) pílula do dia seguinte/contracepção de emergência

08 ( ) coito interrompido/gozar fora

09 ( ) tabelinha

10 ( ) ligadura tubária

11 ( ) vasectomia

12( )outro. Especificar:

77 ( ) não sabe/ não lembra

88 ( ) recusou-se a responder

D.58 Nasuaopinião, porqueestagravidezaconteceu?(espontâneaeúnica, entrevistadora classifica)

01 ( ) esqueceu de tomar a pílula

02 ( ) parou de tomar a pílula

03 ( )ficou doente(diarreia ouvômito), eusoumedicamentos

04 ( ) camisinha estourou ou saiu/escapuliu

05 ( ) não usou a camisinha em todas as relações

06 ( ) coito interrompido falhou/parceiro não fezo coito interrompido

07 ( ) falha do método utilizado

08( ) outromotivo. Especificar:

77 ( ) não sabe/ não lembra

88 ( ) recusou-se a responder

\section{[Após responder pergunta acima, pular para D60]}

D.59 Quandovocêficou grávida, porquevocê(seuparceiro) nãoestavaevitando filho?( espontâneaeúnica)

01 ( ) não achava que fosse engravidar/ não se preocupava com isso

02 ( ) se engravidasse não teria problema

03( ) não tinhaplanejadoter relaçãosexual

04( ) havia interrompidoouso de métodorecentemente (menos de1mês)

05 ( ) parceiro não gostava que usasse método

06 ( ) outrosmotivos. Especificar:

77 ( ) não sabe/ não lembra

88( )recusou-searesponder

D.60 No momento em que você descobriu que estava grávida, você diria que a situação financeira:

(estimulada eúnica)

01 ( ) estava boa, razoável

02 ( ) estava um poucoapertada

03 ( ) estava muito difícil

77 ( ) não sabe/não lembra

88 () recusou-se a responder

D.61 No momentoem quevocê descobriu que estavagrávida, arelação com seuparceiro: (estimuladae única)

01 ( ) estava iniciando

02 ( ) estava estável

03( ) estava instável/ em crise/terminando

04 ( ) não tinha um parceiro fixo

77 ( ) não sabe/não lembra

88() recusou-se aresponder 
D.62 Vocêsofreuviolênciafísicaporpartede seu(algum) parceiroenquantoestavagrávida?

01 ( ) sim

02 ( ) não

77 ( ) não sabe/ não lembra

88() recusou-se a responder

D.63 Em setratandoda decisãodeinterromperagravidez: (estimuladaeúnica)

01 ( )vocêeoseuparceiro estavam deacordoeminterromperagravidez

02 ( ) você queria interromper a gravidez, mas seu parceiro não

03 ( ) seu parceiro queria interromper a gravidez, mas você não

04 ( ) seu parceiro a deixou escolher (se interromperia ou não)

05 ( ) seu parceiro não foi informado da gravidez

06 ( )outro.Especificar:

77 ( ) não sabe/ não lembra

88 ( ) recusou-se a responder

D.64 Antes desse aborto, você conversou a respeito com o seu médico (ginecologista/ médico de família, infectologista)?

01 ( ) sim

02 ( ) não (pular paraD66)

77( ) não sabe/ não lembra (pular paraD66)

88( )recusou-searesponder(pularparaD66)

D.65 Oqueaconteceu quando você contou? (estimulada e múltipla)

01 ( ) foi recriminada

02 ( )foi incentivada aprosseguir agravidez

03 ( ) foi incentivada ainterromper agravidez

04( )foiorientadaparaqueseuabortoocorressedemaneirasegura

05 ( ) não comentaram/orientaram nada

06 ( ) outrasituação. Especificar:

77 ( ) não sabe/ não lembra

88 ( ) recusou-se a responder

D.66 Como o aborto foi realizado? (estimulada e múltipla)

\begin{tabular}{|c|c|c|c|c|}
\hline Como o aborto foi realizado: & $\operatorname{sim}$ & não & $\begin{array}{l}\text { recusa } \\
\text { responder }\end{array}$ & $\begin{array}{l}\text { não sabe / não } \\
\text { lembra }\end{array}$ \\
\hline $\begin{array}{l}\text { a. Com uso de misoprostol (Prostokos, } \\
\text { cytotec, pílula abortiva, comprimidos } \\
\text { abortivos) }\end{array}$ & ( ) & ( ) & ( ) & ( ) \\
\hline $\begin{array}{l}\text { b.Com usodeoutros medicamentos (exceto } \\
\text { misoprostol) }\end{array}$ & ( ) & ( ) & ( ) & ( ) \\
\hline c. Por aspiração, vácuo, sucção & $($ ) & ( ) & $($ ) & $($ ) \\
\hline d. Por meio de curetagem & ( ) & $($ ) & ( ) & $($ ) \\
\hline $\begin{array}{l}\text { e. Com o uso de objetos (sonda, cateter, } \\
\text { agulhas) }\end{array}$ & ( ) & ( ) & ( ) & ( ) \\
\hline f. Com chás e infusões, ervas & $($ ) & $(\mathrm{l})$ & $($ ) & $(\mathrm{l})$ \\
\hline
\end{tabular}

[Se D66a=Sim, sequir para D67, se D66a=Não ou recusa ou não sabe/lembra, pular para D68]

D.67 Como você usou o misoprostol? (estimulada e múltipla)

01 ( ) ingeriu os comprimidos

02() você mesma colocou os comprimidos

03 ( ) parceiro colocou os comprimidos

04( )pessoaleiga colocouoscomprimidos

05 ( ) médico colocou os comprimidos

06( )outro.Especificar:

77 ( ) não sabe/não lembra

88 ( ) recusou-se a responder 
[Seabortorealizado deoutraformaquenãoporaspiração(D66c=1), curetagem(D66d=1) oucomusode objetos (D66e=1), pular para D69]

D.68 Este aborto foi realizado por: (estimulada e múltipla)

01 ( ) médico

02 ( ) enfermeira

03 ( ) parteira

04 ( ) curiosa

05 ( ) você

06( ) outrapessoa. Especificar:

77 ( ) não sabe/não lembra

88 ( ) recusou-se a responder

D.69 Vocêprecisou procuraralgum serviçodesaúdeporcausa deproblemas/ complicações relacionadosao aborto?

01 ( ) sim

02 ( ) não (pular para D72)

77 ( ) não sabe/não lembra

88( )recusou-searesponder

D.70 Você chegouaficar internadapor causa do aborto?

01 ( ) sim

02 ( ) não

77 ( ) não sabe/não lembra

88() recusou-se a responder

D.71 Em algum momento do seu atendimento, você se sentiu maltratada ou humilhada por algum profissional de saúde pelo fato de você ter feito um aborto?

01 ( ) sim

02 ( ) não

77 ( ) não sabe/não lembra

88() recusou-se a responder

D.72 Qualfoi o principal motivo que pesou na decisão de fazer um aborto: (espontânea eúnica)

01 ( ) você não era casada/não estava morando com um parceiro

05 ( ) você não quis ter um filho por que estava sem parceiro

02 ( ) você e/ou seu parceiro não tinham condições de sustentar uma criança

03( )seusfamiliarese/ouosfamiliaresdeseuparceironãoaceitariamagravidez

04 ( ) você não queria um filho naquele momento

06 ( ) parceiro não queria filho naquele momento

07( ) você nãoqueria (mais) filhodaquele parceiro

08( )problemasrelacionadosàviolênciasofridapeloparceiroíntimo

09( ) outromotivo. Especificar:

77 ( ) não sabe/nãolembra

88 ( ) recusou-se a responder

\section{Método após o $1^{\circ}$ aborto}

D.73 Até um ano depois desse aborto, você diria que: (estimulada e única)

01( )passouausaralgum(outro)métodoparaevitaragravidez 02

( ) continuou usando o mesmo método de antes da gravidez

03 ( ) não usou nenhum método (pular para Filtro D4)

04 ( )nãoteverelaçãosexualnesseperíodo(atéumanoapósoaborto)(pularparaFiltro D4)

05 ( ) outrasituação Especificar:

77 ( ) não sabe/não lembra (pular para Filtro D4)

88 ( ) recusou-se a responder (pular para Filtro D4) 
D.74 Qualmétodo vocêusava para evitar gravidez: (espontânea e múltipla)

01 ( ) camisinhamasculina

02 ( ) camisinha feminina

03 ( ) pílulaanticoncepcional

04 ( ) injeção

05 ( ) implante/anel vaginal hormonal/adesivo hormonal

06 ( ) DIU

07( ) pílula do dia seguinte/contracepção de emergência

08 ( ) coito interrompido/gozar fora

09 ( ) tabelinha

10 ( ) ligadura tubária

11 ( ) vasectomia

12( )outro. Especificar:

77 ( ) não sabe/nãolembra

88 ( ) recusou-se a responder

\section{Filtro_D4}

\begin{tabular}{|c|c|c|c|c|}
\hline Tipo de grupo & $\begin{array}{l}\text { Mais de } 1 \\
\text { aborto } \\
\text { provocado }\end{array}$ & $\begin{array}{l}\text { Aborto antes ou } \\
\text { após diagnóstico? }\end{array}$ & $\begin{array}{c}\text { Aborto éaúltima } \\
\text { gravidezou1 } \\
\text { gravidezapós/no } \\
\text { diagnóstico? }\end{array}$ & Ir para \\
\hline \multirow{5}{*}{ MVHA } & \multirow{4}{*}{ Sim } & \multirow{2}{*}{ Antes } & Sim, última gravidez & D106 (último aborto) \\
\hline & & & Não & D97 (último aborto) \\
\hline & & \multirow{2}{*}{ Depois } & $\begin{array}{l}\text { Sim, } 1^{\text {a }} \text { gravidez } \\
\text { após/no diagnóstico }\end{array}$ & $\begin{array}{c}\text { D84 (1ํaborto após } \\
\text { diagnóstico) }\end{array}$ \\
\hline & & & Não & $\begin{array}{c}\text { D75 (1 } 1^{\circ} \text { aborto após } \\
\text { diagnóstico) }\end{array}$ \\
\hline & Não & & & E1 (diagnóstico) \\
\hline \multirow{2}{*}{ MNVHA } & Sim & & $\longrightarrow$ & D37 (último aborto) \\
\hline & Não & & & $\begin{array}{c}\mathrm{F} 1 \text { (planejamento } \\
\text { reprodutivo) }\end{array}$ \\
\hline
\end{tabular}




\section{Sobre o primeiro aborto após o diagnóstico (apenas MVHA)}

Vamos conversar um pouco mais sobre sua experiência do primeiro aborto provocado após o diagnóstico

D.75 Nessa gravidez, que idade tinha seu parceiro?

( ) ( ) anos completos (77 para não sabe/não lembra e 88 para recusa)

D.76 Quandovocêengravidouasuacargaviral estava:(estimuladaeúnica)

01 ( ) alta

02 ( ) baixa

03 ( ) indetectável

04 ( )outro. Especificar:

77 ( ) não sabe/ não lembra

88 ( ) recusou-se a responder

D.77 Nomês emquevocê descobriuque estava grávida, você (ou seu parceiro) estavafazendo/usando alguma coisa para evitar a gravidez/filho?

01 ( ) sim

02 ( ) não (pular paraD80)

77 ( ) não lembra (pular para D80)

88 ( ) recusou-se a responder (pular para D80)

D.78 Oque você(ou o seu parceiro) estavausando para evitar filhosquando soube que estavagrávida? (espontânea emúltipla)

01 ( ) camisinha masculina

02 ( ) camisinha feminina

03( )pílulaanticoncepcional

04 ( ) injeção

05 ( ) implante/anel vaginal hormonal/adesivo hormonal

06 ( ) DIU

07( ) pílula do dia seguinte/contracepção de emergência

08 ( ) coito interrompido/gozar fora

09 ( ) tabelinha

10 ( ) ligadura tubária

11 ( ) vasectomia

12( )outro. Especificar:

77 ( ) não sabe/ não lembra

88 ( ) recusou-se a responder

D.79 Nasuaopinião, porqueestagravidez aconteceu? (espontâneaeúnica)

01 ( ) esqueceu de tomar a pílula

02 ( ) parou de tomar apílula

03 ( )ficou doente(diarreia ouvômito), eusoumedicamentos

04 ( ) camisinha estourou ou saiu/escapuliu

05 ( ) não usou a camisinha em todas as relações

06 ( ) coito interrompido falhou/parceiro não fez o coito interrompido

07 ( ) falha do método utilizado

08( ) outromotivo. Especificar:

77 ( ) não sabe/ não lembra

88 ( ) recusou-se a responder

[Após responder pergunta acima, pular para D81] 
D.80 Quandovocêficou grávida, porquevocê(seuparceiro) nãoestavaevitando filho? (espontâneaeúnica)

01 ( ) não achava que fosse engravidar/ não se preocupava com isso

02 ( ) se engravidasse não teria problema

03( ) não tinhaplanejadoter relaçãosexual

04( ) havia interrompidoouso de métodorecentemente (menos de1mês)

05 ( ) parceiro não gostava que usasse método

06 ( ) outrosmotivos. Especificar:

77 ( ) não sabe/ não lembra

88 ( ) recusou-se a responder

D.81 No momento em que você descobriu que estava grávida, você diria que a situação financeira:

01 ( ) estava boa, razoável

02( ) estava um pouco apertada

03 ( ) estava muito difícil

77 ( ) não sabe/ não lembra

88() recusou-se a responder

D.82 No momento em que você descobriu que estava grávida, a relação com seu parceiro:

01 ( ) estava iniciando

02 ( ) estava estável

03 ( ) estavainstável/ em crise/terminando

04 ( ) não tinha um parceiro fixo

77 ( ) não sabe/não lembra

88() recusou-se a responder

D.83 Vocêsofreuviolênciafísica porpartedeseu(algum) parceiroenquantoestavagrávida?

01 ( ) sim

02 ( ) não

77 ( ) não sabe/ não lembra

88() recusou-se a responder

D.84 Em se tratando da decisão de interromper a gravidez: (estimulada eúnica)

01( )vocêe oseuparceiroestavam deacordoem interromper agravidez

02 ( ) você queria interromper agravidez, mas seu parceiro não

03( )seuparceiroqueriainterromperagravidez,masvocênão

04 ( ) seuparceiroa deixou escolher (se interromperia ou não)

05 ( ) seu parceiro não foi informado da gravidez

06( )outro.Especificar:

77 ( ) não sabe/ não lembra

88 ( ) recusou-se a responder

D.85 Antes desse aborto, você conversou a respeito com o seu médico (ginecologista/médico de família, infectologista)?

01 ( ) $\operatorname{sim}$

02 ( ) não (pular paraD87)

77( ) não sabe/nãolembra (pular paraD87)

88( )recusou-searesponder(pularparaD87)

D.86 Oqueaconteceu quando você contou? (estimulada e múltipla)

01 ( ) foi recriminada

02( ) foi incentivada a prosseguir agravidez

03 ( ) foi incentivada ainterromper agravidez

04( )foiorientadaparaqueseuabortoocorressedemaneirasegura

05 ( ) não comentaram/orientaram nada

06 ( ) outra situação. Especificar:

77 ( ) não sabe/não lembra

88( )recusou-searesponder 
D.87 Como o aborto foi realizado? (estimulada e múltipla)

\begin{tabular}{|c|c|c|c|c|}
\hline Como o aborto foi realizado: & $\operatorname{sim}$ & Não & $\begin{array}{l}\text { recusou-se a } \\
\text { responder }\end{array}$ & $\begin{array}{c}\text { não sabe / não } \\
\text { lembra }\end{array}$ \\
\hline $\begin{array}{l}\text { a. Com uso de misoprostol (Prostokos, } \\
\text { cytotec, pílula abortiva, comprimidos } \\
\text { abortivos) }\end{array}$ & ( ) & ( ) & ( ) & ( ) \\
\hline $\begin{array}{l}\text { b. Com usodeoutros medicamentos (exceto } \\
\text { misoprostol) }\end{array}$ & ( ) & ( ) & ( ) & ( ) \\
\hline c. Por aspiração, vácuo, sucção & $($ ) & $($ ) & $($ ) & $($ ) \\
\hline d. Por meio de curetagem & ( ) & ( ) & ( ) & ( ) \\
\hline $\begin{array}{l}\text { e. Com uso de objetos (sonda, cateter, } \\
\text { agulhas) }\end{array}$ & ( ) & ( ) & ( ) & ( ) \\
\hline f. Com chás e infusões, ervas & $($ ( ) & $($ ( ) & $($ ( ) & () \\
\hline
\end{tabular}

[Se D87a=Sim, sequir para D88, se D87a=Não ou recusa ou não sabe/lembra, pular para D89]

D.88 Como você usou o misoprostol? (estimulada e múltipla)

01 ( ) ingeriu os comprimidos

02 () você mesma colocou os comprimidos

03 ( ) parceiro colocou os comprimidos

04( ) pessoaleiga colocouoscomprimidos

05 ( ) medico colocou os comprimidos

06( )outro. Especificar:

77 ( ) não sabe/não lembra

88 ( ) recusou-se a responder

[Se aborto foi realizado de outra forma que não por aspiração (D87c=1), curetagem (D87d=1) ou com uso de objetos (D87e=1), pular para D90]

D.89 Este aborto foi realizado por: (estimulada e múltipla)

01 ( ) médico

02 ( ) enfermeira

03 ( ) parteira

04 ( ) curiosa

05 ( ) você

06( ) outrapessoa. Especificar:

77 ( ) não sabe/nãolembra

88 ( ) recusou-se a responder

D.90 Vocêprecisou procuraralgum serviçodesaúdeporcausadeproblemas/ complicações relacionados ao aborto?

01 ( ) sim

02 ( ) não (pular paraD93)

77 ( ) nãosabe/nãolembra (pular paraD93)

88( )recusou-searesponder(pularparaD93)

D.91 Vocêchegou aficar internada por causa do aborto?

01 ( ) sim

02 ( ) não

77 ( ) não sabe/não lembra

88() recusou-se a responder

D.92 Em algum momento do seu atendimento, você se sentiu maltratada ou humilhada por algum profissional de saúde pelo fato de você ter feito um aborto?

01 ( ) sim

02 ( ) não

77 ( ) não sabe/não lembra

88( )recusou-searesponder 
D.93 Qualfoio principal motivo que pesou na decisão de fazerum aborto: (espontânea eúnica)

01 ( ) você não era casada/não estava morando com um parceiro

02 ( ) você e/ou seu parceiro não tinham condições de sustentar uma criança

03 ( ) seus familiares e/ou os familiares de seu parceiro não aceitaram/aceitariam a gravidez

04 ( ) você não queria um filho naquele momento

05( ) parceiro nãoqueriafilho naquele momento

06( ) você nãoqueria (mais) filhodaquele parceiro

07 ( ) por causa do HIV

08 ( ) problemas relacionados àviolência sofrida pelo parceiro íntimo

09( ) outromotivo Especificar:

77 ( ) não sabe/nãolembra

88 ( ) recusou-se a responder

D.94 Você diria que, na decisão de abortar, o fato de você ter HIV: (estimulada e única)

01 ( ) foi muitoimportante

02 ( ) foi importante

03 ( ) foi poucoimportante

04 ( ) não foi importante

77 ( ) não sabe/nãolembra

88 ( ) recusou-se a responder

\section{Método após o $1^{\circ}$ aborto depois do diagnóstico}

D.95 Até um ano depois desse aborto, você diria que: (estimulada e única)

01( ) passouausar algum(outro)métodoparaevitaragravidez02

( ) continuou usando o mesmo método de antes dagravidez

03 ( ) não usou nenhum método (pular para Filtro D5)

04 ( )nãoteverelaçãosexualnesseperíodo(atéumanoapósoaborto)(pularparaFiltro D5)

05( ) outra situação Especificar:

77 ( ) não sabe/nãolembra (pular paraFiltro D5)

88( ) recusou-se a responder (pular para Filtro D5)

D.96 Qualmétodo você usa/usava para evitargravidez:(espontânea emúltipla)

01 ( ) camisinhamasculina

02 ( ) camisinha feminina

03 ( ) pílulaanticoncepcional

04 ( ) injeção

05 ( ) implante/anel vaginal hormonal/adesivo hormonal

06 ( ) DIU

07( ) pílula do dia seguinte/contracepção de emergência

08 ( ) coito interrompido/gozar fora

09 ( ) tabelinha

10 ( ) ligadura tubária

11 ( ) vasectomia

12( )outro. Especificar:

77 ( ) não sabe/nãolembra

88 ( ) recusou-se a responder

Filtro D5

\begin{tabular}{|c|c|c|c|}
\hline \multirow{2}{*}{ Tipo de grupo } & $\begin{array}{c}\text { Mais de 1 aborto } \\
\text { provocado }\end{array}$ & $\begin{array}{c}\text { Aborto éa últimagravidezou 1 a } \\
\text { gravidezapós/nodiagnóstico? }\end{array}$ & Ir para \\
\hline \multirow{3}{*}{ MVHA } & \multirow{2}{*}{$\operatorname{Sim}$} & $\operatorname{Sim}$ & D106 (último aborto) \\
\cline { 2 - 4 } & Não & Não & D97 (último aborto) \\
\cline { 2 - 4 } & & & E1 (diagnóstico) \\
\hline
\end{tabular}




\section{Sobre o último aborto provocado (todas que fizeram aborto respondem)}

Vamos conversar um pouco mais sobre sua experiência do último aborto

D.97 Que idade tinha o parceiro de quem você engravidou nessa relação que resultou em aborto?

( ) ( ) anos completos (77 para não sabe/não lembra; 88 para recusa)

[Se MNVHA, pular para D99; se MVHA e não teve aborto após diagnóstico, pular para D99]

D.98 Quandovocêengravidouasuacargaviralestava:(estimuladaeúnica)

01 ( ) alta

02 ( ) caixa

03 ( ) indetectável

04 ( )outro. Especificar:

77 ( ) não sabe/ não lembra

88 ( ) recusou-se a responder

D.99 Nomês emquevocê descobriuque estavagrávida, você (ou seu parceiro) estavafazendo/usando alguma coisa para evitar a gravidez/filho?

01 ( ) sim

02 ( ) não (pular paraD102)

77 ( ) não lembra (pular para D102)

88 ( ) recusou-se a responder (pular para D102)

D.100 Oque você(ou o seu parceiro) estavausando para evitar filhosquando soubeque estavagrávida? (espontânea emúltipla)

01 ( ) camisinha masculina

02 ( ) camisinha feminina

03( )pílulaanticoncepcional

04 ( ) injeção

05 ( ) implante/anel vaginal hormonal/adesivo hormonal

06 ( ) DIU

07( ) pílula do dia seguinte/contracepção de emergência

08 ( ) coito interrompido/gozar fora

09 ( ) tabelinha

10 ( ) ligadura tubária

11 ( ) vasectomia

12( )outro. Especificar:

77 ( ) não sabe/nãolembra

88 ( ) recusou-se a responder

D.101 Nasuaopinião, porqueestagravidez aconteceu? (espontâneaeúnica)

01 ( ) esqueceu de tomar a pílula

02 ( ) parou de tomar a pílula

03 ( )ficou doente(diarreia ouvômito), eusoumedicamentos

04 ( ) camisinha estourou ou saiu/escapuliu

05 ( ) não usou a camisinha em todas as relações

06 ( ) coito interrompido falhou/parceiro não fez o coito interrompido

07 ( ) falha do método utilizado

08( ) outromotivo. Especificar:

77 ( ) não sabe/nãolembra

88 ( ) recusou-se a responder

[Após responder pergunta acima pular para D103] 
D.102 Quandovocêficou grávida, porquevocê(seuparceiro) nãoestavaevitando filho? (espontâneaeúnica)

01 ( ) não achava que fosse engravidar/ não se preocupava com isso

02 ( ) se engravidasse não teria problema

03( ) não tinhaplanejadoter relaçãosexual

04( ) havia interrompidoouso de métodorecentemente (menos de1mês)

05 ( ) parceiro não gostava que usasse método

06 ( ) outrosmotivos. Especificar:

77 ( ) não sabe/ não lembra

88( )recusou-searesponder

D.103 No momento em que você descobriu que estava grávida, você diria que a sua situação financeira:

(estimulada eúnica)

01 ( ) estava boa, razoável

02 ( ) estavaum poucoapertada

03 ( ) estava muito difícil

77 ( ) não sabe/não lembra

88() recusou-se a responder

D.104 Nomomentoemquevocêdescobriuqueestavagrávida,arelaçãocomseuparceiro:(estimuladae única)

01( ) estavainiciando

02 ( ) estava estável

03( ) estava instável/ em crise/terminando

04 ( ) não tinha um parceiro fixo

77 ( ) não sabe/não lembra

88() recusou-se a responder

D.105 Vocêsofreuviolênciafísica porpartede seu(algum) parceiroenquantoestavagrávida?

01 ( ) sim

02 ( ) não

77 ( ) não sabe/ não lembra

88() recusou-se a responder

D.106 Emsetratandodadecisãodeinterromperagravidez:(estimuladaeúnica)

01( ) você e oseuparceiro estavam deacordoem interromper agravidez

02 ( ) você queria interromper a gravidez, mas seu parceiro não

03( )seuparceiroqueriainterromperagravidez,masvocênão

04 ( ) seuparceiroa deixou escolher (se interromperia ou não)

05 ( ) seu parceiro não foi informado da gravidez

06( )outro.Especificar:

77 ( ) não sabe/nãolembra

88 ( ) recusou-se a responder

D.107 Antes desse aborto, você conversou a respeito com o seu médico (ginecologista/médico de família, infectologista)?

01 ( ) sim

02 ( ) não (pular paraD109)

77 ( ) nãosabe/nãolembra (pularparaD109)

88( ) recusou-se a responder (pular para D109)

D.108 Oque aconteceu quando você contou? (estimulada e múltipla)

01 ( ) foi recriminada

02( ) foi incentivada a prosseguir agravidez

03 ( ) foi incentivada ainterromper agravidez

04( )foiorientadaparaqueseuabortoocorressedemaneirasegura

05 ( ) não comentaram/orientaram nada

06( ) outra situação. Especificar: 
77 ( ) não sabe/ não lembra

88() recusou-se a responder

D.109 Como o aborto foi realizado? (estimulada e múltipla)

\begin{tabular}{|l|c|c|c|c|}
\hline Como o aborto foi realizado: & sim & não & $\begin{array}{c}\text { recusou-se a } \\
\text { responder }\end{array}$ & $\begin{array}{c}\text { não sabe/ não } \\
\text { lembra }\end{array}$ \\
\hline $\begin{array}{l}\text { a. Com uso de misoprostol (Prostokos, } \\
\text { cytotec, pílula abortiva, comprimidos } \\
\text { abortivos) }\end{array}$ & $($ ) & $($ ) & $($ ) & $($ ) \\
\hline $\begin{array}{l}\text { b. Com usodeoutros medicamentos (exceto } \\
\text { misoprostol) }\end{array}$ & $($ ) & $($ ) & $($ ) & $($ ) \\
\hline c. Por aspiração, vácuo, sucção & $($ ) & $($ ) & $($ ) & $($ ) \\
\hline d. Por meio de curetagem & $($ ) & $($ ) & $($ ) & $($ ) \\
\hline e. uso de objetos (sonda, cateter, agulhas) & $($ ) & $($ ) & $($ ) & $($ ) \\
\hline f. Com chás e infusões, ervas & $($ ) & $($ ) & $($ ) & \\
\hline g. outra forma. Especificar: & \multicolumn{3}{|l}{} \\
\hline
\end{tabular}

[Se D109a=Sim, sequir para D110, se D109a=Não ou recusa ou não sabe/lembra, pular para D111]

D.110 Como você usou o misoprostol? (estimulada e múltipla)

01 ( ) apenas ingeriu os comprimidos

02 () você mesma colocou os comprimidos

03 ( ) parceiro colocou os comprimidos

04( ) pessoaleiga colocouoscomprimidos

05( ) médico colocou os comprimidos

06( )outro.Especificar:

77 ( ) não sabe/não lembra

88 ( ) recusou-se a responder

[Se aborto foi realizado de outra forma que não por aspiração (D109c=1), curetagem (D109d=1) ou com uso de objetos (D109e=1), pular para D112]

D.111 Este aborto foi realizado por: (estimulada e múltipla)

01 ( ) médico

02 ( ) enfermeira

03 ( ) parteira

04 ( ) curiosa

05 ( ) você

06( ) outrapessoa. Especificar:

77 ( ) não sabe/não lembra

88 ( ) recusou-se a responder

D.112 Vocêprecisou procuraralgum serviçodesaúdepor causadeproblemas/ complicações relacionados ao aborto?

01 ( ) $\operatorname{sim}$

02 ( ) não (pular paraD115)

77( ) não sabe/nãolembra (pular paraD115)

88( ) recusou-se a responder (pularpara D115)

D.113 Você chegou a ficar internada por causa do aborto?

01 ( ) sim

02 ( ) não

77 ( ) não sabe/não lembra

88() recusou-se a responder 
D.114 Em algum momento do seu atendimento, você se sentiu maltratada ou humilhada por algum profissional de saúde pelo fato de você ter feito um aborto?

01 ( ) sim

02 ( ) não

77 ( ) não sabe/não lembra

88() recusou-se a responder

D.115 Qualfoio principal motivo que pesou na decisão de fazer um aborto:(espontânea eúnica)

01 ( ) você não era casada/não estava morando com um parceiro

05 ( ) você não quis ter um filho por que estava sem parceiro

02 ( ) você e/ou seu parceiro não tinham condições de sustentar uma criança

03 ( ) seus familiares e/ou os familiares de seu parceiro não aceitaram/aceitariam a gravidez

04 ( ) você não queria um filho naquele momento

05( ) parceiro não queriafilho naquele momento

06( ) você nãoqueria (mais) filhodaquele parceiro

07( ) por causa do HIV(válida apenas se MVHA)

08( )problemasrelacionadosàviolênciasofridapeloparceiroíntimo

09( ) outromotivo. Especificar:

77 ( ) não sabe/nãolembra

88 ( ) recusou-se a responder

[Se MNVHA, pular para D117]

[Se MVHA e não teve aborto após diagnóstico, pular para D117]

D.116 Você diria que, na decisão de abortar, o fato de você ter HIV: (estimulada e única)

01 ( ) foi muitoimportante

02 ( ) foi importante

03 ( ) foi poucoimportante

04 ( ) não foi importante

77( ) nãosabe/nãolembra

88 ( ) recusou-se a responder

\section{Método após o último aborto}

D.117 Até um ano depois desse aborto, você diria que: (estimulada e única)

01( )passouausaralgum(outro)métodoparaevitaragravidez 02

( ) continuou usando o mesmo método de antes da gravidez

03 ( ) não usou nenhum método (pular para E1)

04 ( ) não teve relação sexual nesse período (até um ano após o aborto) (pularpara E1)

05 ( ) outra situação Especificar:

77 ( ) não sabe/não lembra (pular para E1)

88 ( ) recusou-se a responder (pular para E1)

D.118 Qualmétodovocêusa/usava para evitargravidez:(espontânea emúltipla)

01 ( ) camisinhamasculina

02 ( ) camisinha feminina

03 ( ) pílulaanticoncepcional

04 ( ) injeção

05 ( ) implante/anel vaginal hormonal/adesivo hormonal

06 ( ) DIU

07( ) pílula do dia seguinte/contracepção de emergência

08 ( ) coito interrompido/gozar fora

09 ( ) tabelinha

10 ( ) ligadura tubária

11 ( ) vasectomia

12( )outro. Especificar:

77 ( ) não sabe/nãolembra

88 ( ) recusou-se a responder 


\section{E SOBRE OHIV}

\section{Diagnóstico}

Agora vamos falar um pouco sobre o diagnóstico do HIV.

E.1 Que idade você tinha quando soube que era HIV positivo?
( ) ( ) anos completos
(77 para não sabe/não lembra; 88 para recusa)

E.2 Qual o ano do diagnóstico? ( ) ( ) ( ) ( )

7777 para não sabe/não lembra; 8888 para recusa)

E.3 Onde você morava ao receber/quando soube o diagnóstico? ( ) ( )

\begin{tabular}{|c|c|c|c|}
\hline 1. & São Paulo(SP) & 15. & Pará (PA) \\
\hline 2. & Acre $(A C)$ & 16. & Paraíba (PB) \\
\hline 3. & Alagoas (AL) & 17. & Paraná (PR) \\
\hline 4. & Amapá (AP) & 18. & Pernambuco (PE) \\
\hline 5. & Amazonas (AM) & 19. & Piauí (PI) \\
\hline 6. & Bahia(BA) & 20. & Rio de Janeiro(RJ) \\
\hline 7. & Ceará(CE) & 21. & Rio Grande do Norte(RN) \\
\hline 8. & Distrito Federal (DF) & 22. & Rio Grande do Sul(RS) \\
\hline 9. & EspíritoSanto(ES) & 23. & Rondônia (RO) \\
\hline 10. & Goiás (GO) & 24. & Roraima (RR) \\
\hline 11. & Maranhão (MA) & 25. & Santa Catarina(SC) \\
\hline 12. & Mato Grosso(MT) & 26. & Sergipe (SE) \\
\hline 13. & Mato Grosso do Sul(MS) & 27. & Tocantins (TO) \\
\hline 14. & Minas Gerais(MG) & 28. & outro país. Ėspécificar: \\
\hline
\end{tabular}

E.4 Vocêmudoudecidadedepoisdodiagnóstico?

01 ( ) sim

02 ( ) não

77 ( ) não lembra

88 ( ) recusou-se a responder

E.5 Deque forma vocêacha que adquiriu o vírus? (espontânea eúnica)

01 ( ) através de relação sexual

02 ( ) através do uso de drogas injetáveis

03 ( ) por transmissão vertical (transmissão de mãe para filha)

04 ( ) por transfusão de sangue

05( )outro. Especificar:

77 ( ) não lembra

88 ( ) recusou-se a responder

(Se E5 diferente de 3, pular para E6)

E.5a Como você soube que era HIV positivo (espontânea e única)?

01 ( ) descobriu sozinha

02 ( ) um familiar te contou

03 ( ) um profissionaldesaúde te contou

04 ( ) um/a cuidador/a tecontou

05 ( ) outrasituação. Especificar:

77 ( ) não lembra

88 ( ) recusou-se a responder

(se E5=3, pular para E10) 
E.6 Por que o teste para HIVfoi realizado? (espontânea eúnica)

01 ( ) fez no Pré-natal ou no parto

02 ( ) por iniciativa própria, por rotina/check-up

03 ( ) por iniciativa própria, porque teve relações sexuais desprotegidas

04 ( ) seu parceiro ficou doente/com sintomas de AIDS

05( ) vocêficoudoente/com sintomasdeAIDS

06 ( ) médico pediu fora da gestação ou parto

07 ( ) filho/filha ficou doente/morreu

08 ( ) outrosmotivos. Especificar:

77 ( ) não sabe/ não lembra

88 ( ) recusou-se a responder

E.7 Onde o teste de HIV foi realizado? (espontânea e única)

01 ( )centrode testagem eaconselhamento(CTA/COAS) ouserviçosespecializados deAids

02 ( ) unidade de saúde (SUS/público)

03 ( ) laboratório (privado/convênio)

04 ( ) hospital/ maternidade público

05 ( ) hospital / clínica / maternidade particular (privado)

06 ( ) banco de sangue

07 ( )outro. Especificar:

77 ( ) não sabe/não lembra

88 ( ) recusou-se a responder

E.8 Quandovocêsoube doresultado desseteste, vocêfoi encaminhada pelo profissionalde saúde para fazer acompanhamento em um serviço especializado?

01 ( ) sim

02 ( ) não

03( )outro.Especificar:

77 ( ) não sabe/ não lembra

88 ( ) recusou-se a responder

E.9 Após o diagnóstico, quanto tempo levou para iniciar o acompanhamento num serviço de saúde? (Registre apenas um campo: se menos de 1 semana, registre "01"; se menos de 1 mês registre as semanas; semenosde1ano, registreosmeses; se1anooumais, registreosanos; nosdemaiscampos registre "00")

( ) ( ) semanas ( ) ( ) meses ( ) ( ) anos (77 para não lembra; 88 para recusa)

E.10 QuandovocêsoubeserHIVpositivo,vocêcontouparaalguém?

01 ( ) sim

02 ( ) não (pular para E12)

77 ( ) não lembra (pular para E12)

88 ( ) recusou-se a responder (pular para E12)

E.11 Para quais pessoasvocêcontouquandosoubedodiagnóstico? (espontânea emúltipla)

01 ( ) marido/parceiro/namorado/ "ficante"

02 ( ) pai/padrasto

03 ( ) mãe/madrasta

04 ( ) filhos/as

05 ( ) irmão/irmã

06 ( ) outrosfamiliares

07 ( ) amigo(a)(s)

08( ) colegasdetrabalho/chefe

09 ( ) outro

77 ( ) não lembra

88 ( ) recusou-se a responder

[Entrevistadora: Se MVHA, nunca teve relação sexual e tem entre 18 e 24 anos, pular para E34] 
[Entrevistadora: Se quando o diagnóstico foi dado, a mulher já tinha iniciado a vida sexual, segue para E12; se o diagnóstico foi dado antes dela iniciar a vida sexual (transmissão vertical ou uso de drogas), pular para E34)

\section{Sobre o/a parceiro/a da época do diagnóstico}

Vamos falar agora sobre seu relacionamento à época do diagnóstico

E.12 Quandovocêrecebeu odiagnóstico ou soube queera HIVpositivo, vocêtinha algum parceiro sexual?

01 ( ) sim

02 ( ) não (pular para E25)

77 ( ) não lembra (pular para E25)

88 ( ) recusou-se a responder (pular para E25)

E.13 Esse parceiro é/era: (estimulada e única)

01 ( ) o parceiroda primeira união(pular para E20)

02 ( ) o parceiro atual (pular para E20)

03 ( ) outro parceiro

E.14 Vocêdiriaqueesse parceiro era:(estimulada eúnica)

01 ( ) fixo/estável

02 ( ) ocasional/eventual (pular para E25)

E.15 Quantos anos você tinha quando iniciou esse relacionamento?

( ) ( ) anos completos (77 para não sabe/não lembra; 88 para recusa)

E.16 Quantos anos tinha o seu parceiro no início do relacionamento?
( ) ( ) anos completos
(77 para não sabe/não lembra; 88 para recusa)

E.17 Quantotempodurouesserelacionamento? (Registreapenas um campo: osmeses, se menos de 1ano; e os anos, se 1 ano ou mais; os demais registre "00")
( ) ( ) meses
( ) ( ) anos
(77 para não sabe/não lembra; 88 para recusa)

E.18 Vocês nãoestãomaisjuntosporquenaquelaépoca:(estimuladaeúnica)

01 ( ) vocês se separaram

02 ( ) ele morreu

77 ( ) não lembra

88 ( ) recusou-se a responder

E.19 Vocês chegaram a morar juntos?

01 ( ) sim

02 ( ) não

77 ( ) não lembra

88 ( ) recusou-se a responder

E.20 Você contou para este parceiro que era HIV positivo?

01 ( ) sim

02 ( ) não (pular paraE22)

03 ( )souberamjuntos(pularpara E22)

77( ) não lembra (pular para E22)

88 ( ) recusou-se a responder (pular para E22)

E.21 Em que momento você contou? (estimulada e única)

01 ( ) imediatamente/logo após saber que era soropositiva

02 ( ) nostrêsmeses seguintes à descobertada infecção

03 ( ) mais tarde durante o relacionamento

77 ( ) não sabe / não lembra

88() recusou-se a responder 
E.22 Oparceiro com quem você estavanaépoca do seudiagnóstico era positivo?

01 ( ) sim

02 ( ) não (pular para E24)

77 ( ) não sabe (pular para E24)

88 ( ) recusou-se a responder (pular para E24)

E.23 Emquemomentoeletecontou?(estimuladaeúnica)

01( )elecontouantes desuaprimeirarelaçãosexual

02( )elesócontoudepoisdaprimeirarelaçãosexual

03( )já estava com o parceiro quandoele soubequetinha ovírus

04 ( ) souberam juntos

05( ) ele nãome contou, soube de outramaneira

77 ( ) não sabe / não lembra

88 ( ) recusou-se a responder

E.24 Vocêachaqueseinfectou comesseparceiro?(válidaapenasparatransmissãosexual,E5=1)

01 ( ) sim (pular para E26)

02 ( ) não

77 ( ) não sabe

88 ( ) recusou-se a responder

E.25 Com quem você acha que se infectou? (estimulada e única) (válida apenas para transmissão sexual, $\mathrm{E} 5=1$ )

01 ( ) com um (outro) parceiro fixo

02 ( ) com um parceiro eventual

77 ( ) não sabe (pular para E27)

88 ( ) recusou-se a responder

E.26 Como você acha que seu parceiro se infectou? (espontânea e única) (válida apenas para transmissão sexual, E5=1)

01 ( ) através de relaçãosexual

02 ( ) através do uso de drogas injetáveis

03 ( ) por transmissão vertical (transmissão de mãe para filho)

04 ( ) por transfusão de sangue

05( )outro. Especificar:

77 ( ) não sabe

88 ( ) recusou-se a responder

E.27 Antes/próximo à época do diagnóstico, você (ou seu parceiro) estava fazendo/usando alguma coisa para evitar a gravidez/filho? (Lembre-se que estamos considerando tudo que você usa ou faz para evitar filhos, inclusive o coito interrompido, camisinha e a esterilização?)

01 ( ) $\operatorname{sim}$

02 ( ) não (pular paraE29)

77 ( ) não lembra (pular para E29)

88 ( ) recusou-se a responder (pular para E29)

E.28 Oque você(ouo seuparceiro) estavausandoparaevitar filhosquandovocêsoube dodiagnóstico?

(espontânea emúltipla)

01 ( ) camisinha masculina

02 ( ) camisinha feminina

03( )pílulaanticoncepcional

04 ( ) injeção

05 ( ) implante/anel vaginal hormonal/adesivo hormonal

06 ( ) DIU

07( ) pílula do dia seguinte/contracepção de emergência

08 ( ) coito interrompido/gozar fora

09 ( ) tabelinha 
10 ( ) ligadura tubária

11 ( ) vasectomia

12( )outro. Especificar:

77 ( ) não sabe/ nãolembra

88 ( ) recusou-se a responder

E.29 Antes/próximoàépoca do diagnóstico, vocêusava acamisinha:(estimuladaeúnica)
01 ( ) sempre
02 ( ) às vezes
03 ( ) nunca
77 ( ) não sabe/ não lembra
88( ) recusou-searesponder

\section{Situação atual}

Agora vamos falar um pouco sobre sua situação atual.

[Entrevistadora: Se mulher não tem relacionamento sexual atualmente (C26=2), pular para E34] [SeoparceirododiagnósticoéoparceiroatualeelacontouparaelequeeraHIVpositivoousouberam juntos (E20=1 ou E20=3), pular para E32]

E.30 Você contou para o parceiro atual que é HIV positivo?

01 ( ) sim

02( ) não (pularparaE32)

03 ( ) souberam juntos

77 ( ) não lembra (pular para E32)

88 ( ) recusou-se a responder (pular para E32)

E.31 Em que momento você contou? (estimulada eúnica)

01 ( ) antes de sua primeira relação sexual

02 ( ) nos três primeiros meses do relacionamento

03 ( ) maistarde, em outromomentodo relacionamento

04 ( ) souberam juntos

77 ( ) não sabe/não lembra

88() recusou-se a responder

[Se o parceiro do diagnóstico é o parceiro atual e ele é HIV positivo, pular para E34]

[Se oparceiro do diagnóstico éo parceiroatual eele éHIVnegativo ou ela não sabe, seguepara E32a]

E.32 a.OseuparceiroatualjáfeztesteparaoHIV?
01 ( ) sim
02 ( ) não (pular paraE34)
03 ( ) nãosabe(pularparaE34)
88 ( ) recusou-se a responder (pular para E34)

E32b.VocêsabequandofoiaúltimavezqueelefezotesteparaHIV(incluirtestefeitonadoaçãode sangue)?
01 ( ) não
02 ( ) há menos de um ano
03 ( ) há um ano ou mais
77 ( ) nãosabe/nãolembra
88 ( ) recusou-se a responder

E32c. Você sabe qual o resultado do último teste para o HIV do seu parceiro atual?

01 ( ) sim, ele é HIV positivo

02 ( ) sim, ele é HIV negativo

03 ( ) não sabe

88 ( ) recusou-se a responder 
[Se parceiro atual é HIV negativo ou ela não sabe, pular para E34]

[Separceiroatualé HIV positivo eelejácontou, pularpara E34]

E.33 Em que momento ele te contou que era positivo? (estimulada eúnica)

01 ( ) ele contou antes de sua primeira relação sexual

02 ( ) ele só contou depois da primeira relação sexual

03 ( ) jáestava com oparceiro quandoele soubeque tinha ovírus

04 ( ) souberam juntos

05( ) ele nãome contou, soube de outramaneira

77 ( ) não sabe / não lembra

88 ( ) recusou-se a responder

E.34 Atualmente (mais) alguém sabe que você é HIV positivo? (espontânea e múltipla, entrevistadora sinalizar todas as pessoas quesabem do diagnóstico no momento atual, excluindo o parceiro)

01 ( ) ninguém sabe

02 ( ) pai/padrasto

03 ( ) mãe/madrasta

04 ( ) filhos/as

05 ( ) irmão/irmã

06 ( ) outrosfamiliares

07 ( ) amigo(a)(s)

08 ( ) colegas de trabalho/chefe

09 ( )outro. Especificar:

77 ( ) não sabe/ não lembra

88 ( ) recusou-se a responder

E.35 Atualmente, na sua casa ou na sua família tem mais alguém que é HIV positivo?

01 ( ) sim

02 ( ) não (pular para E37)

77( ) não sabe/nãolembra (pularpara E37)

88( )recusou-searesponder(pularparaE37)

E.36 Quem é essa pessoa? (estimulada e múltipla)

01 ( ) pai/padrasto

02 ( ) mãe/madrasta

03 ( ) esposo/companheiro

04 ( ) namorado

05 ( ) filho/a

06 ( ) irmã/ão

07 ( )outro. Especificar:

77 ( ) não sabe/ não lembra

88 ( ) recusou-se a responder

\section{Agora vamos falar um pouco sobre tratamento e prevenção}

E.37 Atualmente vocêusaalgumamedicaçãoparaoHIV/AIDS?

01 ( ) sim

02 ( ) não (pular para E41)

88 ( ) recusou-se a responder (pular para E41)

E.38 Háquantotempo você usa ARV? (Registre apenas um campo: osmeses, se menos de 1 ano; e os anos, se 1 ano ou mais; os demais registre "00")
( ) ( ) meses
( ) ( ) anos completos
(77 para não sabe/não lembra; 88 para recusa)

E.39 Com relação ao tratamento, você diria que: (estimulada e única)

01 ( ) você não tem efeitos colaterais

02 ( ) você tem poucos efeitoscolaterais 
03 ( ) vocêtemmuitos efeitoscolaterais epassamuitomal

04 ( ) já teve muitos efeitos colaterais, atualmente não

05( )outro.Especificar:

77 ( ) não sabe/ não lembra

88 ( ) recusou-se a responder

E.40 Desde que você iniciou o tratamento, você diria que: (estimulada e única)

01 ( ) nunca interrompeu nem deixou de tomar os remédios

02 ( )nuncainterrompeumasjádeixoudetomarosremédiosalgumasvezes

03 ( ) nunca interrompeu mas deixa sempre de tomar os remédios

04 ( ) interrompeu poucas vezes o tratamento por sua conta

05 ( ) interrompeu várias vezes o tratamento por sua conta

06 ( )outro. Especificar:

77 ( ) não sabe/ não lembra

88 ( ) recusou-se a responder

E.41 Quanto mediu o seu último CD4?

( ) ( ) ( ) ( ) (7777 para não sabe/não lembra; 8888 para recusa)

E.42 Suaúltimacargaviralestava:(estimuladaeúnica)

01 ( ) alta

02 ( ) baixa

03 ( ) indetectável

04 ( )outra. Especificar:

77 ( ) não sabe/ não lembra

88 ( ) recusou-se a responder

Os exames de sangue que você faz regularmente mostram o seu CD4 e sua carga viral.

E.43 O objetivo do tratamento é aumentar ou diminuir o seu CD4? (estimulada e única)

01 ( ) aumentar

02 ( ) diminuir

77( ) não sabe/nunca ouviu falar

88( ) recusou-se a responder

E.44 O objetivo do tratamento é aumentar ou diminuir a carga viral? (estimulada e única)

01 ( ) aumentar

02 ( ) diminuir

77( ) não sabe/nunca ouviu falar

88( ) recusou-se a responder

E.45 Quandoacarga viral está indetectável orisco detransmitir o HIV narelação sexualé: (estimuladae única)

01 ( ) alto

02 ( ) baixo

03 ( ) é muito baixo

04 ( ) éomesmo, nãofaz diferença

77 ( ) não sabe/ nunca ouviu falar

88( ) recusou-se a responder

E.46 Você já ouviu falar de PEP, um tratamento de urgência tomado imediatamente após umarelação sexual para impedir atransmissão do HIVa uma pessoa soronegativa? (estimuladánica)

01 ( ) $\operatorname{sim}$

02 ( ) não (pular paraE48)

77( ) não sabe/ nunca ouviu falar

88( ) recusou-se a responder

Se MVHA virgem e entre 18 e 24 anos, pular para E53] 
E.47 Algumparceiroseujáusou?

01 ( ) sim

02 ( ) não

03 ( )sóteverelaçãosexualcomPVHA

77 ( ) não sabe

88 ( ) recusou-se a responder

\section{Mudanças na vida sexual depois do diagnóstico}

Agora vamosconversar sobre algumas mudanças que podem ou não teracontecido na sua vida sexual depois do diagnóstico de HIV.

E.48 Depois que você soube que era HIV positivo, a sua vontade/ seu desejo de ter relações sexuais: (estimulada eúnica)

01 ( ) aumentou

02 ( ) diminuiu

03 ( ) continuou igual

77 ( ) não sabe

88 ( ) recusou-se a responder

E.49 - Depoisque vocêsoubequeera HIVpositivo, o númeroderelações sexuais:(estimulada eúnica)

01 ( ) aumentou

02 ( ) diminuiu

03 ( ) continuou igual

04 ( ) você não teve mais relações sexuais após o diagnóstico

77 ( ) não sabe

88 ( ) recusou-se a responder

[Se E49=4, pular para E51]

E.50 Depois que você soube que era HIV positivo, o uso de camisinha nas relações sexuais: (estimulada e única)

01 ( ) aumentou

02 ( ) diminuiu

03 ( ) continuou igual

04 ( )nuncausoucamisinha

77 ( ) nãosabe

88 ( ) recusou-se a responder

Violência e discriminação relacionada ao diagnóstico

Agoravamosconversarsobrealgumassituaçõesligadasaodiagnósticode HIVquepodem teracontecido com você.

E.51 Jáaconteceudeumapessoaserecusaraterrelações sexuais comvocêporquevocê é HIVpositivo?

01 ( ) sim

02 ( ) não

77 ( ) não sabe / não lembra

88 () recusou-se a responder

E.52 Já aconteceu de um/a parceiro/a sexual romper com você porque você é HIV positivo?

01 ( ) sim

02 ( ) não

77 ( ) não sabe / não lembra

88 () recusou-se a responder

E.53 Você já foi agredida verbalmente, humilhada ou ofendida por ser HIV positivo?

01 ( ) sim

02 ( ) não (pular para E55)

77( ) não sabe/não lembra (pularpara E55)

88( )recusou-searesponder(pularparaE55) 
E.54 Quem era/eram essa/essas pessoa/pessoas que lhe ofendeu/ofenderam/ humilhou/humilharam? (espontânea emúltipla)

01 ( ) parceiro íntimo

02 ( ) pai/padrasto

03 ( ) mãe/madrasta

04 ( ) outros familiares

05 ( ) amigos

06 ( ) colega/s detrabalhoou chefe

07 ( ) profissional de saúde

08 ( ) desconhecido

09 ( )outro. Especificar:

77 ( ) não sabe/ não lembra

88 ( ) recusou-se a responder

E.55 Você já foiagredida fisicamente porser HIVpositivo?

01 ( ) sim

02 ( ) não (pular para E57)

77( ) não sabe/nãolembra (pularparaE57)

88( )recusou-searesponder(pularparaE57)

E.56 Quem era/eramessa/essaspessoa/pessoasque lhe agrediu/agrediram? (espontâneaemúltipla)

01 ( ) parceiro íntimo

02 ( ) pai/padrasto

03 ( ) mãe/madrasta

04 ( ) outros familiares

05 ( ) amigos

06 ( ) colega/s de trabalho ou chefe

07 ( ) profissional de saúde

08 ( ) desconhecido

09 ( )outro. Especificar:

77 ( ) não sabe/ não lembra

88 ( ) recusou-se a responder

E.57 Você já se sentiu discriminada dentro de algum serviço de saúde por ser HIV positivo?

01 ( ) sim

02 ( ) não (pular para F1)

77 ( ) não sabe/nãolembra (pularparaF1)

88( )recusou-searesponder(pularparaF1)

E.58 Deque forma você se sentiu discriminada? (estimulada e múltipla)

01 ( ) através de ofensa verbal

02 ( ) através de tratamento desigual

03 ( ) você não recebeu informações, mesmo tendo solicitado

04( ) outro.Especificar:

77 ( ) não sabe/ não lembra

88() recusou-se a responder

(Se MVHA virgem e entre 18 e 24 anos, pular para F21) 


\section{F. INTENÇÃO DE TER FILHOS EPLANEJAMENTO REPRODUTIVO (MVHA e MNVHA)}

Agoravamosfalarum poucomaissobre formasde evitar filhos, vamosretomar tudo que você já usouna vida. Primeiro vamos conversar um pouco sobre pílula do dia seguinte/contracepção de emergência. Essa pílula é usada após ter relações sexuais quando você acha que pode correr risco de engravidar.

Você já ouviu falar na pílula do dia seguinte/contracepção deemergência? 01 (

) $\operatorname{sim}$

02 ( ) não (pular para F8)

77( ) não sabe/ nãolembra (pularpara F8)

88( )recusou-searesponder(pularparaF8)

De onde vieram as informações sobrepílula do diaseguinte/contracepção deemergência? (espontâneae múltipla)

01( ) mídia(TV, rádio, jornal, revistas)

02 ( ) trabalho

03 ( ) escola

04 ( )serviçosdesaúde

05 ( ) parceiro

06 ( ) com amigas/os, parentes ou conhecidas/os

07 ( )outro. Especificar:

77 ( ) não sabe/ não lembra

88 ( ) recusou-se a responder

F.3. Algumavezna vida vocêjá usoua pílula dodia seguinte/contracepção deemergência?

01 ( ) sim

02 ( ) não (pular para F7)

77( ) nãosabe/ nãolembra (pularpara F8)

88( )recusou-searesponder(pularparaF8)

F.4 Quantasvezesvocêusoupílula dodiaseguinte/contracepçãodeemergêncianavida:(estimuladaeúnica)

01 ( ) Umavez

02 ( ) 2 a 10 vezes

03 ( ) Mais de 10 vezes

77 ( ) não sabe/ não lembra

88 () recusou-se a responder

F.5 Nosúltimos 12 meses, quantasvezesutilizouapíluladodiaseguinte/contracepçãodeemergência?

[Se F5=0, pular para F8]
( ) ( )
(77paranãolembra;88pararecusa;00senãousounosúltimos12meses)

F.6 Naúltima vezquevocê usou, aondefoi obtida a pílula do dia seguinte/contracepção de emergência?

(espontânea eúnica)

01 ( ) comprou na farmácia

02( ) nesteserviço de saúde

03( )emoutroserviçodoSUS. Especificar:

04 ( ) gratuitamente na farmácia Dose certa

05 ( )outro. Especificar:

77 ( ) não sabe/ não lembra

88 ( ) recusou-se a responder

[Após responder pergunta acima, pular para F8] 
F.7 Qualfoioprincipalmotivoparavocênão/nuncaterusado?(espontânea eúnica)

01 ( ) se engravidasse, não teria problemas

02( )porquenuncateverelaçãosexualsemestarevitandofilho

03( ) nuncaachouque estivesse correndoriscode engravidar

04 ( ) não sabia como obter o método

05 ( ) método era caro e não tinha dinheiro suficiente

06 ( ) porque a considera como um método abortivo

07 ( ) nunca pensou no assunto

08 ( ) não conhecia/havia a contracepção de emergência na época

09( ) outro.Especificar:

77 ( ) não sabe/ não lembra

88() recusou-se a responder

\section{Agora vamos conversar um pouco sobre a camisinha feminina}

F.8 Vocêjá ouviu falar na camisinha feminina?

01 ( ) sim

02 ( ) não (pular para F16)

77( ) não sabe/nãolembra (pularparaF16)

88( )recusou-searesponder(pularparaF16)

F.9 Vocêjárecebeuouganhou umacamisinhafeminina?
01 ( ) sim
02 ( ) não
77 ( ) não sabe/ não lembra
88 () recusou-se a responder

F.10 Vocêjáusouacamisinhafeminina?

01 ( ) sim (pular para F12)

02 ( ) não

77( ) não sabe/ nãolembra (pular para F16)

88( ) recusou-se a responder (pular para F16)

F11 Porque vocênunca usoua camisinha feminina?(espontânea emúltipla)

01 ( ) porque não tive curiosidade/interesse

02 ( ) porque meu parceiro não quis usar

03 ( ) porque émuito grande,feia, desconfortável

04 ( ) porque prefiro a masculina

05( )outro.Especificar:

77 ( ) não sabe/ não lembra

88 ( ) recusou-se a responder

[Após responder pergunta acima, pular para F16]

F.12 Você diria que jáusou a camisinha feminina na vida:(estimulada e única)

01 ( ) uma vez

02 ( ) 2 a 10 vezes

03 ( ) mais de 10vezes

77 ( ) não sabe/ não lembra

88 () recusou-se a responder

F.13 Nos últimos 12 meses, quantas vezes utilizou a camisinha feminina?

[Se F13=00, pular para F15]

(00 se não usou; 77 para não sabe/não lembra; 88 para recusa) 
F.14 Ondeconseguiuacamisinhafemininanaúltimavezquevocêusou? (espontâneaeúnica)

01 ( ) neste serviço de saúde

02 ( ) em outro serviço do SUS

03 ( ) conseguiu em ONG, associações de bairro etc.

04 ( ) comprou na farmácia

05( )conseguiucomamigos,parentesouconhecidos

06( )outro. Especificar:

77 ( ) não sabe/ não lembra

88 ( ) recusou-se a responder

F.15 Com relação a camisinha feminina, você diria que:

\begin{tabular}{|l|c|c|c|c|}
\hline Camisinha feminina: & Sim & não & $\begin{array}{c}\text { recusa } \\
\text { responder }\end{array}$ & não sabe \\
\hline a. Gostaria de usar com mais frequência & $($ ) & $($ ) & $($ ) & $($ ) \\
\hline b. Deixou de usar porque parceiro não gostou & $($ ) & $($ ) & $($ ) & $($ ) \\
\hline c. Ela é difícil de inserir / pouco prática & $($ ) & $($ ) & $($ ) & $($ ) \\
\hline d. E muito difícil de conseguir & $($ ) & $($ ) & $($ ) & $($ ) \\
\hline e. Prefere usar a camisinha masculina & $($ ) & $($ ) & $($ ) & $($ ) \\
\hline f. Eu não voltaria a usar & $($ ) & $($ ) & $($ ) & $($ ) \\
\hline
\end{tabular}

[Seo usodecamisinhanão foi referidoatéomomento, perguntar F16, caso contrário, pularpara F17]

\section{Agora, vamos conversar um pouco sobre a camisinha masculina}

F.16 Você jáusoucamisinhamasculinaalgumavez navida?

01 ( ) sim

02 ( ) não (pular para F18)

77( ) não sabe/nãolembra (pularparaF18)

88( )recusou-searesponder(pularparaF18)

F.17 Você diria que já deixou /deixa de usar a camisinha masculina:

\begin{tabular}{|l|c|c|c|c|}
\hline Uso de camisinha masculina: & sim & não & $\begin{array}{c}\text { recusa } \\
\text { responder }\end{array}$ & não sabe \\
\hline a. para sentir mais prazer na relação sexual & $($ ) & $($ ) & $($ ) & $($ ) \\
\hline b. quando faz coito interrompido & $($ ) & $($ ) & $($ ) & $($ ) \\
\hline c. para sentir maior proximidade/intimidade com o parceiro & $($ ) & $($ ) & $($ ) & $($ ) \\
\hline d. para não causar desconfiança no parceiro & $($ ) & $($ ) & $($ ) & $($ ) \\
\hline e. porque é muito cara para ser usada em todas as relações & $($ ) & $($ ) & $($ ) & $($ ) \\
\hline f.[somente se MVHA] para não levantar suspeita sobre sua sorologia & $($ ) & $($ ) & $($ ) & $($ ) \\
\hline g.[somente se MVHA] quando a carga viral está/estava baixa & $($ ) & $($ ) & $($ ) & $($ ) \\
\hline h. [somente se MVHA] quando o parceiro também é soropositivo & $($ ) & $($ ) & $($ ) & $($ ) \\
\hline
\end{tabular}

F.18 Vamos agora recapitular todas formas de evitar gravidez/filhos que você já usou na vida? (estimulada e múltipla)

\begin{tabular}{|l|c|c|c|c|}
\hline Métodos na vida: & sim & não & $\begin{array}{r}\text { recusa } \\
\text { responder }\end{array}$ & não sabe \\
\hline a. Camisinha masculina & $($ ) & $($ ) & $($ ) & $($ ) \\
\hline b. Camisinha feminina & $($ ) & $($ ) & $($ ) & $($ ) \\
\hline c. Pílula anticoncepcional & $($ ) & $($ ) & $($ ) & $($ ) \\
\hline d. Injeção & $($ ) & $($ ) & $($ ) & $($ ) \\
\hline e. DIU & $($ ) & $($ ) & $($ ) & $($ ) \\
\hline f. Pílula do dia seguinte/CE & $($ ) & $($ ) & $($ ) & $($ ) \\
\hline g. Coito interrompido/gozar fora & $($ ) & $($ ) & $($ ) & $($ ) \\
\hline h. Tabelinha & $($ ) & $($ ) & $($ ) & $($ ) \\
\hline i. Ligadura tubária & $($ ) & $($ ) & $($ ) & $($ ) \\
\hline j. Vasectomia & $($ ) & $($ ) & $($ ) & $($ ) \\
\hline k. outro método Especificar: & \multicolumn{5}{l}{}
\end{tabular}

[Se F18i=1 (laqueadura), pular para F26] 
F.19 Dentreasformas/os métodos quevocêcitou, qual deles vocêusou primeiro na vida? (espontâneae única)

01 ( ) camisinha masculina

02 ( ) camisinha feminina

03( )pílulaanticoncepcional

04 ( ) injeção

05 ( ) implante/anel vaginal hormonal/adesivo hormonal

06 ( ) DIU

07( ) pílula do dia seguinte/contracepção de emergência

08 ( ) coito interrompido/gozar fora

09 ( ) tabelinha

10 ( ) ligadura tubária

11 ( ) vasectomia

12( )outro. Especificar:

77 ( ) não sabe/ não lembra

88 ( ) recusou-se a responder

F.20 Quandovocê utilizou este método pela primeiravez? (espontânea eúnica, entrevistadora classifica)

01 ( ) antes da/ na primeira relaçãosexual

02( ) depoisdaprimeirarelaçãosexual

03 ( ) depois de engravidar

77 ( ) não sabe/não lembra

88() recusou-se a responder

Agora vamos falar um pouco sobre seus planos com relação a filhos.

F.21 Você quer ter (outros) filhos? (se grávida perguntar além deste filho que está esperando)

01 ( ) sim, biológico

02 ( ) sim, adotado

03 ( ) sim, ambos

04 ( ) não

77( ) nãosabe/nãolembra (pularpara F26)

88( )recusou-searesponder(pularparaF26)

[Se(F21=1 ou F21=3) e MVHA, pularpara F24]

[Se (F21=1 ou F21=3) e MNVHA, pular para F26]

[Se(F21=10uF21=3)egrávida, pularparaF26]

F.22 Qualéo principal motivo para você não querer ter (mais) filhos (biológicos)? (espontânea eúnica, entrevistadora classifica)

01 ( ) porque nunca quis terfilhos

02 ( ) játem o número desejado de filhos

03( ) por estar sem companheiro

04 ( ) por falta de condições socioeconômicas

05 ( ) porque filho é muita responsabilidade, dá muito trabalho

06 ( )[somente se MVHA] por ser HIVpositivo ou pormedo detransmitir ovírus aobebê

07 ( ) porque não pode ter filhos (outras razões que não HIV)

08( ) outro . Especificar:

77 ( ) não sabe/ não lembra

88 ( ) recusou-se a responder

[Se MNVHA, pular para F26]

F.23 Dentre os motivos para não querer ter filhos, você diria que o fato de você ter HIV é um motivo:

(estimulada eúnica)

01 ( ) muito importante

02 ( ) importante

03 ( ) pouco importante

04 ( ) não é importante 
77 ( ) não sabe/não lembra

88() recusou-se a responder

[Após responder pergunta acima, pularparaF26]

[Se grávida, pular para F41]

F.24 Vocêfalousobreseudesejodeengravidarnoserviçodesaúde?

01 ( ) $\operatorname{sim}$

02 ( ) não (pular para F26)

77( ) não sabe/nãolembra (pularparaF26)

88( )recusou-searesponder(pularparaF26)

F.25 Que tipo de orientação você recebeu do serviço? (estimulada e múltipla)

01 ( ) não recebeu nenhuma orientação

02 ( ) orientação para reduzir a carga viral antes da gravidez

03 ( ) orientação para ter relações sexuais apenas no período fértil

04 ( ) encaminhamento para reprodução assistida (inseminação médica, fertilização in vitro)

05 ( ) recomendação de não engravidar

06( )outra. Especificar:

77 ( ) não sabe/nãolembra

88 ( ) recusou-se a responder

\section{Esterilização}

F.26 Vocêfez ligadura/ligação detrompas?

01 ( ) sim

02 ( ) não

88 ( ) recusou-se a responder

[Se mulher não mantém relacionamento sexual atualmente, pular para Filtro F1]

F.27 Seu parceiro atualfezvasectomia, cirurgia queohomemfazparanãotermaisfilhos?(espontânea eúnica, entrevistadora classifica)

01 ( ) sim, vasectomia anterior ao início do relacionamento com ela (pular para Filtro_F1)

02 ( ) sim,vasectomiaduranteorelacionamentocomela

03 ( ) não (pular para Filtro F1)

77 ( ) não sabe (pular para Filtro F1)

88 ( ) recusou-se a responder (pular para Filtro F1)

[Apenas se F26=1 e F27=2: ATENÇÃO ENTREVISTADORA: "Se mulher fez ligação de trompas E parceiro com vasectomia, as perguntas abaixo (F28 a F38) vão SEMPRE se referir à ligação de trompas".

Filtro_F1: [Se mulher não tem relacionamento sexual atualmente e é laqueada (F26=1), seguir para F28; se nãoé laqueada e/ou parceironãoévasectomizado oué maséanteriorao relacionamentocom ela, pular para F41]

F.28 Que idade vocêtinha na época da esterilização? Se mulher fez ligação de trompas E parceirofez vasectomia, a pergunta se refere à ligação de trompas
( ) ( ) anos completos
(77 para não sabe/não lembra; 88 para recusa)

F.29 Queidadeseuparceirotinhana épocadaesterilização? Semulherfezligação detrompasEparceirofez vasectomia, a pergunta se refere idade do parceiro na ligação de trompas.
( ) ( ) anos completos
(77 para não sabe/não lembra; 88 para recusa))

F.30a Quantosfilhos vivosvocêtinha naquele momento?(Nocasodeligaçãodetrompasrealizadanacesárea ou parto, considerar a criança nascida)
( ) ( )filhos/as vivo/s
(77 para não sabe/não lembra; 88 para recusa) 
F. Ob Quantos filhos vivos seu parceiro da/naquela época tinha?
( ) ( )filhos/as vivo/s
(77 para não sabe/não lembra; 88 para recusa)

F.31 Quantos desses filhos vivos eram de vocês dois?
( ) ( )filhos/as vivo/s
(77 para não sabe/não lembra; 88 para recusa)

F.32 Qualomotivo maisimportantequefezcomque(você/seuparceiro)decidissepelaligadura(vasectomia)

? (espontânea e única, entrevistadora classifica)

01 ( ) já tinha o número desejados de filhos / não quer mais filhos

02 ( ) porqueéum método definitivo/ para não se preocupar com filhos

03 ( ) por indicação médica em função de problema de saúde

04 ( ) método que faz menos mal à saúde

05 ( ) por causa do HIV (válida apenas para MVHA)

06 ( ) aligação de trompas foi feita sem a minha autorização (válida apenas para laqueadas, F26=1)

07( ) outro. Especificar:

77 ( ) não sabe/ não lembra

88() recusou-se a responder

[Se MNVHA, pularpara F34]

[Se F32=6, pular para F34]

F.33 Você diriaque, na decisãodefazer a ligaçãodetrompas/vasectomia, ofato devocê(s) ter(em) HIVfoi:

(estimulada eúnica)

01 ( ) muito importante

02 ( ) importante

03 ( ) pouco importante

04 ( ) não foi importante

05 ( )fezantesdo diagnóstico

77 ( ) não sabe/não lembra

88( ) recusou-se aresponder

[Se F26=2, pular para F35]

F.34 Em que momento você fez essa ligadura: (estimulada e única) (Válida apenas para ligação de trompas, $\mathrm{F} 26=1)$

01 ( ) durante a cesariana

02 ( ) logodepoisdo partonormal (namesma internação)

03 ( ) não foi feita na ocasião do parto

77 ( ) não sabe/ não lembra

88() recusou-se a responder

[Se ID1=1 (MNVHA), pular para F36]

[Se ID1=2 (MVHA) e F26=2 (ela não é laqueada) e F27=3 (nem parceiro vasectomizado), pular para F36]

[Se ID1 =2 (MVHA) e F26=1 (ela é laqueada), continuar F35]

F.35 Essaesterilizaçãofoifeita:(estimuladaeúnica)

01 ( ) antes do diagnóstico de HIV

02( ) no parto dagestaçãoem quefoidiagnosticada

03 ( ) depois do diagnóstico de HIV

77 ( ) não sabe/ não lembra

88() recusou-se a responder

F.36 Ondefoifeitaaligação detrompas/vasectomia? (espontânea eúnica, entrevistadoraclassifica)

01 ( ) serviço de saúde do SUS (centro/ posto de saúde ou hospital)

02( ) serviço de saúde ligado aos convênios/ planos de saúde

03 ( ) serviço de saúde particular

04( )outro. Especificar:

77( ) não sabe/ não lembra

88( ) recusou-se a responder 
F.37 Você/seuparceiropagoupelaligaçãodetrompas/vasectomia?

01 ( ) sim

02 ( ) não

77 ( ) não sabe/ não lembra

88() recusou-se a responder

F.38 Por que decidiram que você (ou seu parceiro) é quem deveria fazer a ligação de trompas (vasectomia)?

Por favor me diga qual o principal motivo. (espontânea e única)

01 ( ) porque nãotinha parceiro/a na época

02 ( ) porque parceiro/a équem nãoqueria maisfilhos

03( ) porque é mais fácil de fazer a cirurgia

04( ) porqueémaisfácil de conseguir acirurgia

05( ) porque émais fácil de reverter a cirurgia

06 ( ) para controlar afidelidade do parceiro/a

07 ( ) para poupar companheiro(a) de uma cirurgia

08 ( ) porqueoparceiro/vocêserecusouafazer a cirurgia

09 ( ) recomendação do médico

10 ( ) não conversamos arespeito

11 ( ) outromotivo. Especificar:

77 ( ) não sabe/ não lembra

88 ( ) recusou-se a responder

[Se F26=2, pular para F41]

F.39 Se você fosse decidir hoje, vocêfaria de novo a ligação de trompas?

01 ( ) $\operatorname{sim}$ (pular para G1)

02 ( ) não

77( ) não sabe/ nãolembra (pularpara G1)

88( )recusou-searesponder(pularparaG1)

F.40 Porque nãofaria novamente? Porfavor me digaqual o principal motivo.(espontânea eúnica)

01 ( ) mudou de parceiro

02 ( ) você quer outro filho

03 ( ) parceiro quer outro filho

04 ( ) algum filho morreu

05( ) efeitos colaterais / problemas de saúde associados à operação

06 ( ) a operação falhou, e engravidou novamente

07( ) diminuiu ointeresse por sexo

08( ) conheceu outros métodos

09( ) outromotivo. Especificar:

77 ( ) não sabe/ não lembra

88 ( ) recusou-se a responder

[Após responder pergunta acima, pular para G1]

F.41 Vocêgostaria defazer umaligadura detrompas?

01 ( ) sim

02 ( ) não (pular para F48)

77 ( ) não sabe (pular para G1)

88 ( ) recusou-se a responder (pular para G1)

F.42 Em que momento você gostaria de fazer uma ligação de trompas? (espontânea eúnica, entrevistadora classifica) Se grávida, não deverá ser registrada a categoria 2.

01 ( ) no próximo parto (cesariana ou parto normal)

02 ( ) assim que possível, sem precisar engravidar para obter aligação

03 ( ) em algum momento do futuro (que não os momentos acima)

04( )outro. Especificar:

77( ) não sabe/ não lembra

88( ) recusou-se a responder 
F.43 Porquevocêgostaria de fazer uma ligadura de trompas? Por favor me diga qual o principal motivo.

(espontânea eúnica)

01 ( ) já tem o número desejados de filhos

02 ( ) porqueé um método definitivo/para nãose preocupar comfilhos

03 ( ) por indicação médica em função de problema de saúde

04 ( ) método que faz menos mal à saúde

06 ( ) por causa do HIV (válida apenas para MVHA)

07 ()outro.Especificar:

77 ( ) não sabe/ não lembra

88 ( ) recusou-se a responder

F44 Você já conversou com algum profissional de saúde sobre seu desejo de fazer a ligação de trompas?

01 ( ) sim

02 ( ) não (pular para F46)

77 ( ) não lembra (pular para F46)

88 ( ) recusou-se a responder (pular para F46)

F.45 Nessaocasião, oprofissional desaúde:(estimulada e múltipla)

01 ( ) desestimulou arealização da ligação de trompas

02( )estimulouarealizaçãodaligaçãodetrompas

03 ( ) esclareceu suas dúvidas

04 ( ) encaminhou para serviço que realiza a ligação de trompas

05 () outros.Especificar:

77 ( ) não sabe/ não lembra

88() recusou-se a responder

F.46 Você gostaria de já ter feito a ligação de trompas antes?

01 ( ) sim

02 ( ) não (pular para G1)

77( ) não sabe/não lembra (pularparaG1)

88( ) recusou-se a responder (pularpara G1)

F47 Porquenãofez antes? Porfavor me diga qualo principal motivo.(espontânea eúnica)

01 ( ) aguarda ser chamada/o pelo serviço

02( ) disseramque não podefazer porqueé/erajovem e/outem/tinha poucosfilhos

03 ( ) por falta de dinheiro para pagar

04 ( ) porque o parceiro não apoiou / não concordou

05 ( )porqueaindanãoprocurouserviçoparaconseguiracirurgia

06( ) outro.Especificar:

77 ( ) não sabe/ não lembra

88() recusou-se a responder

[Após responder pergunta acima, pular para G1]

F.48 Por que não gostaria de fazer uma ligação de trompas? Por favor me diga qual o principal motivo.

(espontânea e única, entrevistadora classifica)

01 ( ) você aindaquer ter (outro) filho

02 ( ) parceiro quer outrofilho

03 ( ) teme efeitos colaterais/problemas de saúde associados à operação

04 ( ) tem medo de que diminua seu interesse por sexo

05 ( ) considera uma atitude muito radical/prefere manter abertaa opção de terfilhos

06 ( ) prefere usar outros métodos/está bem adaptada a outros métodos

07 ( ) não pensou sobre o assunto

08 ( ) porque meu parceiro já fez vasectomia

09 ( ) outromotivo. Especificar:

77 ( ) não sabe/ não lembra

88 ( ) recusou-se a responder 


\section{G. VIOLÊNCIA}

Vamos conversar um pouco sobre situações que podem ou não ter acontecido com você.

G.1 Na sua vida alguém jálhe bateu, esbofeteou, chutou ou machucou fisicamente?

01 ( ) sim

02 ( ) não (pular para G6)

77( ) não sabe/não lembra (pular para G6)

88( )recusou-searesponder(pularparaG6)

G.2 Nasuavida,quantasvezesissoaconteceu?(estimuladaeúnica)

01 ( ) uma ou duas vezes

02( )algumasvezes

03 ( ) muitas vezes

77 ( ) não sabe/ não lembra

88 () recusou-se a responder

G.3 Quem a agrediu /agrediu? (espontânea e múltipla)

01 ( ) qualquer parceiro íntimo (companheiro, namorado, marido, noivo, "ficante")

02 ( ) outro membro da família

03 ( ) amigo/a

04 ( ) colega de trabalho/chefe

05 ( ) desconhecido/a

06 ( )outro.Especificar:

77 ( ) não sabe/ não lembra

88 ( ) recusou-se a responder

G.4 Isso aconteceu: (estimulada e única)

01 ( ) na sua infância ou adolescência (até seus 15 anos)

02 ( ) após os 15 anos

03 ( ) antes e após os 15 anos

77 ( ) não sabe/ não lembra

88( )recusou-searesponder

G.5 Issoaconteceu nosúltimos 12meses?

01 ( ) sim

02 ( ) não

77 ( ) não sabe/ não lembra

88() recusou-se a responder

G.6 Nasuavidaalguémjálhequeimou,usououameaçouusarfacaouarmadefogoparateferir fisicamente?

01 ( ) sim

02 ( ) não (pular paraG11)

77( ) não sabe/ nãolembra (pularparaG11)

88( )recusou-searesponder(pularparaG11)

G.7 Nasuavida,quantasvezes issoaconteceu?(estimuladaeúnica)

01 ( ) uma ou duas vezes

02( )algumasvezes

03 ( ) muitas vezes

77 ( ) não sabe/ não lembra

88() recusou-se a responder 
G.8 Quem tequeimou,ameaçouusarouferiucomfacaouarmadefogo?(espontâneaemúltipla)

01 ( ) qualquer parceiro íntimo (companheiro, namorado, marido, noivo, "ficante")

02 ( ) outro membro da família

03 ( ) amigo/a

04 ( ) colega de trabalho/chefe

05 ( ) desconhecido/a

06 ( )outro.Especificar:

77 ( ) não sabe/ não lembra

88 ( ) recusou-se a responder

G.9 Isso aconteceu: (estimulada e única)

01 ( ) na sua infância ou adolescência (até seus 15 anos)

02 ( ) após os 15 anos

03( ) antes e após os 15 anos

77 ( ) não sabe/ não lembra

88( )recusou-searesponder

G.10 Issoaconteceunosúltimos12meses?

01 ( ) sim

02 ( ) não

77 ( ) não sabe/ não lembra

88() recusou-se a responder

[Se MVHA e virgem pular para G18]

G.11 Alguma vez na vida, você foi forçada a ter relações sexuais, por se sentir ameaçada ou temer ser agredida?

01 ( ) sim

02 ( ) não (pular paraG18)

77 ( ) não sabe/ nãolembra (pularpara G18)

88( )recusou-searesponder(pularparaG18)

G.12 Nasuavida,quantasvezes issoaconteceu?(estimuladaeúnica)

01 ( ) uma ou duas vezes

02( )algumasvezes

03 ( ) muitas vezes

77 ( ) não sabe/ não lembra

88() recusou-se a responder

G.13 Quem a força/forçou? (espontânea e múltipla)

01 ( ) qualquer parceiro íntimo (companheiro (namorado, marido, noivo, "ficante")

02 ( ) outro membro da família

03 ( ) amigo/a

04 ( ) colega detrabalho/chefe

05 ( ) desconhecido/a

06( ) outro. Especificar:

77 ( ) não sabe/ não lembra

88 ( ) recusou-se a responder

G.14 Isso aconteceu: (estimulada e única)

01( )nasuainfânciaouadolescência(atéseus15anos)

02 ( ) após os 15 anos

03( ) antes e após os 15 anos

77 ( ) não sabe/ não lembra

88( )recusou-searesponder 
G.15 Issoaconteceu nosúltimos 12meses?
01 ( ) sim
02 ( ) não
77 ( ) não sabe/ não lembra
88() recusou-se a responder

G.16 Comquemvocêconversou sobre aviolênciasexual sofrida? (espontânea emúltipla)
01 ( ) ninguém
02 ( ) amigo/a/s
03 ( ) família dela
04 ( ) marido/parceiro/namorado/"ficante"
05 ( ) família do marido/companheiro/a
06 ( ) policial
07 ( ) profissional de saúde
08 ( ) ONG/ organização de mulheres
09 ( )outro.Especificar:
77 ( ) não sabe/ não lembra
88 ( ) recusou-se a responder

[Se MNVHA, pular para G18]

[Se MVHA e sofreu violência de outra pessoa que não o parceiro íntimo, pular para G18]

G.17 Vocêdiriaque essassituações:(estimulada eúnica)

01 ( ) começaram depois do diagnóstico

02 ( ) aumentaram/pioraram depois do diagnóstico

03( ) diminuíram/melhoraramdepoisdodiagnóstico

04 ( ) não mudaram com o diagnóstico

05 ( ) aconteceram antes do diagnóstico/ não se relacionam com o diagnóstico

06( ) outro.Especificar:

77 ( ) não sabe/ não lembra

88() recusou-se a responder

[Se não sofreu nenhum violência física e/ou sexual ou recusou responder, pular para G19]

G.18 Você foia algum serviço paraobter ajuda devido à agressão (física e/ou sexual) sofrida? (estimulada e múltipla)

01 ( ) não procurei nenhum serviço

02 ( ) polícia/delegacia

03 ( ) hospital ou centros desaúde

04 ( ) serviço especializado para atendimento a mulher vítima de violência

05() outrosserviços. Especificar:

77 ( ) não sabe/ não lembra

88 ( ) recusou-se a responder

[Se MVHA virgem e entre 18 e 24 anos, pular para H1]

G.19 Nasuavida vocêjáse sentiuagredida verbalmente, humilhada ouofendida por algum parceirosexual?

01 ( ) sim

02 ( ) não (pular para H1)

77( ) não sabe/nãolembra (pular para H1)

88( )recusou-searesponder(pularparaH1)

G.20 Nasuavida,quantasvezes issoaconteceu?(estimuladaeúnica)

01 ( ) uma ou duas vezes

02( )algumasvezes

03 ( ) muitas vezes

77 ( ) não sabe/ não lembra

88() recusou-se a responder

[Se MNVHA, pular para H1] 
G.21 Vocêdiriaque essassituações:(estimulada eúnica)

01 ( ) começaram depois do diagnóstico

02 ( ) aumentaram/pioraram depois do diagnóstico

03( ) diminuíram/melhoraramdepoisdodiagnóstico

04 ( ) não mudaram com o diagnóstico

05 ( ) aconteceram apenas antes do diagnóstico

06( )outro.Especificar:

77 ( ) não sabe/ não lembra

88 ( ) recusou-se a responder 


\section{H. USO DE DROGAS E SEXO COMERCIAL}

Vamos falar agora sobre outras experiências de vida.

H.1 Alguma vez na vida, você utilizou alguma destas drogas ilícitas que vou mencionar?

\begin{tabular}{|l|c|c|c|c|}
\hline \multicolumn{1}{|c|}{ Já usou alguma destas drogas? } & sim & não & $\begin{array}{c}\text { recusa } \\
\text { responder }\end{array}$ & não sabe \\
\hline a. Cocaína & $($ ) & $($ ) & $($ ) & $($ ) \\
\hline b. Crack/merla/pedra & $($ ) & $($ ) & $($ ) & $($ ) \\
\hline c. Anfetamina (rebite/boleta/bolinhas) & $($ ) & $($ ) & $($ ) & $($ ) \\
\hline d. Ecstasy & $($ ) & $($ ) & $($ ) & $($ ) \\
\hline $\begin{array}{l}\text { e. Coladesapateiro, loló, éter, esmalte,tinta } \\
\text { ou solventes }\end{array}$ & $($ ) & $($ ) & $($ ) & $($ ) \\
\hline $\begin{array}{l}\text { f. Você já usou alguma outra droga não } \\
\text { mencionada? Especificar: }\end{array}$ & $($ ) & $($ ) & $($ ) & $($ ) \\
\hline
\end{tabular}

H.2 Vocêjáusoualguma drogainjetável?
01 ( ) sim
02 ( ) não
88 ( ) recusou-se a responder

[Se H1a-H1f=1 (sim), perguntar H3; se H1a a H1f=2 (não), pular para H5]

H.3 Nos últimos 6 meses, com que frequência você usou

(drogas mencionadas)?

\begin{tabular}{|l|c|c|c|c|c|}
\hline & $\begin{array}{c}\text { Nenhuma } \\
\text { vez }\end{array}$ & $\begin{array}{c}\text { Menos de uma } \\
\text { vez por mês }\end{array}$ & $\begin{array}{c}\text { Pelo menos uma } \\
\text { vez por mês ou } \\
\text { mais }\end{array}$ & $\begin{array}{c}\text { Uma vez por } \\
\text { semana ou mais }\end{array}$ & $\begin{array}{c}\text { Recusou-se a } \\
\text { responder }\end{array}$ \\
\hline a. Cocaína & $($ ) & $($ ) & $($ ) & $($ ) & $($ ) \\
\hline b. Crack/merla/pedra & $($ ) & $($ ) & $($ ) & $($ ) & $($ ) \\
\hline $\begin{array}{l}\text { c.Anfetamina } \\
\text { (rebite/boleta/bolinhas) }\end{array}$ & $($ ) & $($ ) & $($ ) & $($ ) \\
\hline d. Ecstasy & $($ ) & $($ ) & $($ ) & $($ ) & $($ ) \\
\hline $\begin{array}{l}\text { e. Colade deapateiro, loló, } \\
\text { éter, esmalte, tinta ou } \\
\text { solventes }\end{array}$ & $($ ) & $($ ) & $($ ) & $($ ) & $($ ) \\
\hline $\begin{array}{l}\text { f. Você já usou alguma } \\
\text { outra droga não } \\
\text { mencionada? Especificar: }\end{array}$ & $($ ) & $($ ) & $($ ) & \\
\hline
\end{tabular}

[SeH3a-H3f="nenhuma vez", seguir paraH4; se H3a=H3f\#"nenhuma vez", pular para H5]

H.4 Qualeraafrequênciacomquevocêusava (drogas mencionadas)?

\begin{tabular}{|l|c|c|c|c|c|}
\hline & $\begin{array}{c}\text { Uma vez/só } \\
\text { experimentou }\end{array}$ & $\begin{array}{c}\text { Menos de uma } \\
\text { vez por mês }\end{array}$ & $\begin{array}{c}\text { Pelo menos } \\
\text { umavezpor } \\
\text { mês oumais }\end{array}$ & $\begin{array}{c}\text { Uma vez por } \\
\text { semana ou } \\
\text { mais }\end{array}$ & $\begin{array}{c}\text { Recusou-se a } \\
\text { responder }\end{array}$ \\
\hline a. Cocaína & $($ ) & $($ ) & $($ ) & $($ ) & $($ ) \\
\hline b. Crack/merla/pedra & $($ ) & $($ ) & $($ ) & $($ ) & $($ ) \\
\hline $\begin{array}{l}\text { c.Anfetamina } \\
\text { (rebite/boleta/bolinhas) }\end{array}$ & $($ ) & $($ ) & $($ ) & $($ ) & $($ ) \\
\hline d. Ecstasy & $($ ) & $($ ) & $($ ) & $($ ) \\
\hline $\begin{array}{l}\text { e. Colade sapateiro, loló, } \\
\text { éter, esmalte, tinta ou } \\
\text { solventes }\end{array}$ & $($ ) & $($ ) & $($ ) & $($ ) & $($ ) \\
\hline $\begin{array}{l}\text { f. Você já usou alguma } \\
\text { outra droga não } \\
\text { mencionada? Especificar: }\end{array}$ & $($ ) & $($ ) & $($ ) & \\
\hline
\end{tabular}


H.5 Vocêjátevealgumparceiro sexualusuáriodedrogas?

01 ( ) sim

02 ( ) não

77 ( ) não sabe/ não lembra

88() recusou-se a responder

H.6 Atualmente, você convive com alguém (parceiro, familiar ou amigo/a) que seja usuário de droga?

01 ( ) sim

02 ( ) não (pular paraH8)

77 ( ) não sabe/ nãolembra (pular para H8)

88( )recusou-searesponder(pularparaH8)

H.7 Queméessapessoa?(espontânea emúltipla)

01( )marido/companheiro/namorado 02

( ) pai/padrasto

03 ( ) mãe/madrasta

04 ( ) filho/a

05 ( ) irmão/ã

06 ( ) amigos/as, colegas

07 ( )outro.Especificar:

88 ( ) recusou-se a responder

[Se MVHA virgem e entre 18 e 24 anos, pular para 11]

H.8 Alguma vez navida, você fez sexo em troca de dinheiro? Quero reforçar, novamente, que tudo que você disser será mantido em segredo.

01 ( ) sim

02 ( ) não (pular paral1)

88 ( ) recusou-se a responder (pular para I1)

H.9 Atualmente, vocêfaz sexo em troca de dinheiro?

01 ( ) sim

02 ( ) não

88 ( ) recusou-se a responder

H.10 Por quanto tempo você fez/há quanto tempo você faz sexo em troca de dinheiro? (espontânea e única, entrevistadora classifica)

01 ( ) menos de 1 mês

02 ( ) entre 1 mês e 6 meses

03 ( ) entre 6 meses e 1 ano

04 ( ) entre 1 ano e 5 anos

05 ( ) mais de 5 anos

77 ( ) não sabe/ não lembra

88() recusou-se a responder

H.11 Com que frequência aproximadamente você fazia/faz sexo em troca de dinheiro? (espontânea e única, entrevistadora classifica)

01 ( ) fez uma ou duas vezes

02 ( ) menos de uma vez por mês (esporadicamente)

03 ( ) todo omês/pelo menosuma vezpor mês(regularmente)

77 ( ) não sabe/ não lembra

88 ( ) recusou-se a responder 


\section{Doenças Sexualmente Transmissíveis}

I.1 Vocêjátevealgumadoençasexualmentetransmissível(DST),quesepegaatravésdosexo?

01 ( ) sim.

02 ( ) não (pular para 14)

77( ) não sabe/ não lembra (pular para 14)

88( )recusou-searesponder(pularparal4)

I.2 Qual/quais DSTs? (espontânea emúltipla)

01 ( ) HPV

02 ( ) sífilis

03 ( ) hepatite

04 ( ) herpes

05( )outra.Especificar:

77 ( ) não sabe/ não lembra

88 ( ) recusou-se a responder

I.3. Nos últimos 12 meses, você teve alguma doença sexualmente transmissível (DST)?

01 ( ) sim

02 ( ) não (pular para 14)

77 ( ) não sabe/ não lembra (pular pra 14)

88( )recusou-searesponder(pularparal4)

I.3a Qual/quais DSTs? (espontânea e múltipla)

01 ( ) HPV

02 ( ) sífilis

03 ( ) hepatite

04 ( ) herpes

05( )outra. Especificar:

77 ( ) não sabe/ não lembra

88 ( ) recusou-se a responder

I.4 Você já fez exame preventivo do câncer de colo de útero ou o Papanicolaou?

01 ( ) sim

02 ( ) não (pular para J1)

77( ) nãosabe/ nãolembra (pularparaJ1)

88( )recusou-searesponder(pularparaJ1)

[Se MNVHA, pular para 16]

I.5 Você chegou a fazer o exame preventivo do câncer de colo de útero antes de saber que era soropositiva?

(espontânea e única, entrevistadora classifica)

01 ( ) nuncafazia 02

( ) fazia todo ano

03( ) fazia pelo menos a cada 3 anos

04( )fazia em intervalos maiores doque 3 anos

77 ( ) não sabe/ não lembra

88 ( ) recusou-se a responder

I.6 Com que frequência você fazexame preventivo do câncer de colo de útero (se MVHA acrescentar no início da pergunta, Edepois do diagnóstico)? (espontânea e única, entrevistadora classifica)

01 ( ) nuncafaz 02

( ) faz todo ano

03 ( ) faz pelo menos a cada 3 anos

04 ( ) fazem intervalos maiores doque 3 anos

77 ( ) não sabe/ não lembra

88 ( ) recusou-se a responder 
I.7 Quandofoia última vez que você fez o exame preventivo do câncer de colo de útero? (espontânea eúnica, entrevistadora classifica)

01 ( ) hámenos de 6 meses

02 ( ) entre 6 e 12 meses

03 ( ) entre 12 e 36 meses (entre 1 e 3 anos)

04 ( ) há mais de 36 meses (mais de 3 anos)

77 ( ) não sabe/ não lembra

88 ( ) recusou-se a responder 


\section{J. SERVIÇO DESAÚDE}

Parafinalizar, vamos falar umpouco sobreoserviço de saúde no qualvocêestáconsultandonessemomento

J.1 Háquanto tempo vocêfrequenta este serviço (Registreapenas um campo: os meses, se menos de 1 ano; e os anos, se 1 ano ou mais; os demais registre "00")

( ) ( ) meses (se menos de 1 ano) ( ) ( ) anos (77 para não sabe/nãolembra; 88 pararecusa)

(Se $\mathrm{J} 1=00 \mathrm{em}$ todos os campos, pular para J6)

J.2 Temalgum profissional nesteserviçoem quemvocêconfia paraesclarecer dúvidassobre métodospara evitar gravidez ou doenças transmitidas pelo sexo?

01 ( ) sim

02 ( ) não (pular paraJ4)

77( ) não sabe/ nãolembra (pular para J4)

88( )recusou-searesponder(pularparaJ4)

J.3 Quais são os profissionais em que você mais confia: (espontânea e múltipla)

01 ( ) médico

02 ( ) enfermeira(o)

03 ( ) técnico ou auxiliar de enfermagem

04 ( ) assistente social

05 ( ) psicóloga(o)

06 ( ) agente comunitário de saúde

07 ( )outro.Especificar:

77 ( ) não sabe

88 ( ) recusou-se a responder

J.4 Nesse serviço de saúde, você recebeu informações sobre: (estimulada e múltipla)

\begin{tabular}{|l|c|c|c|c|}
\hline \multicolumn{1}{|c|}{ Informações sobre: } & sim & não & $\begin{array}{c}\text { recusa } \\
\text { responder }\end{array}$ & não sabe \\
\hline a. camisinha masculina & $($ ) & $($ ) & $($ ) & $($ ) \\
\hline b. camisinha feminina & $($ ) & $($ ) & $($ ) & $($ ) \\
\hline c. pílula anticoncepcional & $($ ) & $($ ) & $($ ) & $($ ) \\
\hline d. injeção anticoncepcional & $($ ) & $($ ) & $($ ) & $($ ) \\
\hline e. DIU & $($ ) & $($ ) & $($ ) & $($ ) \\
\hline $\begin{array}{l}\text { f. pílula do dia seguinte/contracepção de } \\
\text { emergência }\end{array}$ & $($ ) & $($ ) & $($ ) & $($ ) \\
\hline g. coito interrompido/gozar fora & $($ ) & $($ ) & $($ ) & $($ ) \\
\hline h. ligadura tubária & $($ ) & $($ ) & $($ ) & $($ ) \\
\hline i. vasectomia & $($ ) & $($ ) & $($ ) & $($ ) \\
\hline
\end{tabular}

J.5 Você diria que nesse serviço:

\begin{tabular}{|l|c|c|c|c|}
\hline & sim & não & $\begin{array}{r}\text { recusa } \\
\text { responder }\end{array}$ & não sabe \\
\hline $\begin{array}{l}\text { a. existe demora no agendamento de } \\
\text { consultas }\end{array}$ & $($ ) & $($ ) & $($ ) & $($ ) \\
\hline $\begin{array}{l}\text { b. existe demora no agendamento de } \\
\text { exames }\end{array}$ & $($ ) & $($ ) & $($ ) & $($ ) \\
\hline c. as consultas são muito rápidas & $($ ) & $($ ) & $($ ) & $($ ) \\
\hline $\begin{array}{l}\text { d.osprofissionaisseinteressam pouco } \\
\text { pelo seu estado de saúde ou } \\
\text { conversam pouco com você }\end{array}$ & $($ ) & $($ ) & $($ ) & $($ ) \\
\hline $\begin{array}{l}\text { e. existe com frequência falta de } \\
\text { medicamentos }\end{array}$ & $($ ) & $($ ) & $($ ) & $($ ) \\
\hline f. médicos faltam com frequência & $($ ) & $($ ) & $($ ) & $($ ) \\
\hline
\end{tabular}


J.6 Nosúltimosdoisanos, algum profissionaldesaúdenesteouemqualquer outroserviçodesaúde serecusou a te atender?

01 ( ) sim

02 ( ) não

77 ( ) não sabe/não lembra

88() recusou-se a responder

J.7 Nosúltimos dois anos, já aconteceu de você ser mal tratada por algum profissional de saúde?

01 ( ) sim

02 ( ) não

77 ( ) não sabe/não lembra

88() recusou-se a responder 


\section{K. ENCERRAMENTO:}

Bom, estamos chegando ao fim do questionário, gostaríamos de saber sua opinião sobre a entrevista.

K.1 Oque você achou da entrevista (estimulada e múltipla):

01 ( ) chata

02( ) interessante

03 ( ) importante

04 ( ) indiscreta

05 ( ) muitolonga

06( ) outro. Especificar:

[Se MVHA virgem e entre 18 e 24 anos, pular para hora do término da entrevista]

Agora, para finalizar, gostaríamos que você própria respondesse mais duas questões, sem eu olhar suas respostas. Voufazeraperguntaemostrarasrespostasparaquevocêmesmapossaregistrar nocomputador.

K.2 Alguma vez na vida, você foi forçada a ter relações sexuais, por se sentir ameaçada ou sentir medo de ser agredida?

01 ( ) sim

02 ( ) não

88 ( ) recusa-se a responder

K.3 Alguma vez na vida, você já provocou um aborto (aborto provocado)?

01 ( ) sim

02 ( ) não

88 ( ) recusa-se a responder

ENTREVISTADOR, REGISTRE A HORA DOTÉRMINO DA ENTREVISTA: horas / minutos 
ANEXO B -

\section{CENTRO DE REFERENCIAE $\bigcirc$ Plotoforma TREINAMENTO DST/AIDS \\ graril}

\section{PARECER CONSUBSTANCIADO DO CEP}

\section{DADOS DO PROJETO DE PESQUISA}

Titulo da Pesquisa: Estudo sobre práticas e decisōes relativas à saúde sexual e reprodutiva no contexto da epidemia de HIVIAIDS no municipio de Såo Paulo - Estudo GENIH

Pesquisador: Regina Maria Barbosa

Área Temática:

Versâo: 4

CAAE: 11712112.6 .0000 .5375

Instituiçăo Proponente: Centro de Referéncla e Treinamento DST/AIDS

Patrocinador Principal: Conselho Nacional de Desenvolvimento Clentifico e Tecnologico ((CNPq))

\section{DADOS DO PARECER}

Número do Parecer: 201.758

Data da Relatoria: 21/02/2013

\section{Apresentação do Projeto:}

O projeto propōe investigar aspectos da saúde sexual e reprodutiva de mulheres vivendo com HIV/Aids (MVHA) e comparando-os com mulheres soronegativas para o HIV, ou nāo vivendo com HIVIAids (MNVHA). Especial atençăo será dada à influência de dimensóes do contexto social e relacional dessas mulheres, particularmente a presença de situaçőes de violência de gênero sofrida, e do contexto institucional de cuidado à saúde nas práticas sexuais e reprodutivas de mulheres de ambos os grupos. $\mathrm{O}$ estudo é quantitativo de corte transversal será conduzido no municipio de Sáo Paulo para comparar duas amostras representativas de MVHA e MNVHA usuárias dos serviços públicos de saúde. A populaçăo do estudo serả composta por 2.000 mulheres entre 18 e 49 anos matriculadas e usuárias regulares dos serviços públicos de saúde selecionados para compor a amostra, localizados no municipio de Sáo Paulo, Brasil. Atualmente, a atençầo à saúde da mulher com HIV está centrada basicamente no aspecto reprodutivo de proteção à maternidade, com a introduçāo da prevençâo da transmissão vertical. Desta forma, a inexistênicia ou insuficiência de politicas públicas que efetivem o direito ao acesso a serviços de saúde sexual e reprodutiva demonstra a fragilidade desses serviços em propor estratégias de reduçăo de risco. O estudo pretende contribuir para melhorar as açoes de cuidado â saude sexual e reprodutiva de mulheres vivendo com HIV. no sentido do respeito as suas escolhas reprodutivas e da garantia de que estas poderāo ocorrer de modo seguro. Nesse sentido, este estudo alinha-se com as diretrizes do Plano Integrado de Enfrentamento da Epidemia de Aids, elaborado pelo Ministério da Saúde, em

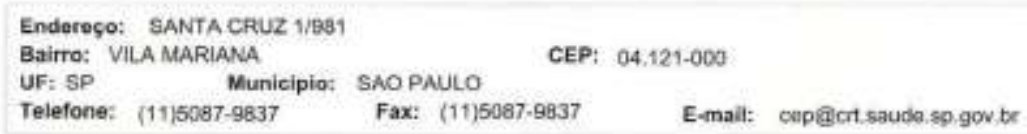




\section{CENTRO DE REFERENCIAE Plotoforma TREINAMENTO DST/AIDS}

parceria com a Secretária de Politicas para as Mulheres (Brasil, 2009).Objetivo Primảrio:

Investigar aspectos da saúde sexual e reprodutiva de mulheres vivendo com HIVIAids (MVHA) e comparando-os com mulheres soronegativas para o HIV (MNHA). Especial atenção será dada à influência de dimensōes do contexto social e relacional dessas mulheres, particularmente a presença de situaçōes de violéncia de gênero sofrida, e do contexto institucional de cuidado à saúde nas práticas sexuais e reprodutivas de mulheres de ambos os grupos.

Insituiçăo Responsável: NEPO - Núcleo de Estudos da população/UNICAMP.

Insituiçס̄es Parceiras:

Centro de Referência e Treinamento em DST/AIDS - SES-SP

Area Ténica de Saúde da Mulher - SES-SP

Programa Municipal de DST/AIDS - SP

Insituto de Infectologia Emilio Ribas - IIER

Ambulatório de Infectologia Disciplina de Infectologia - EMP/ UNIFESP

Insituto de Saúde São Paulo - SES-SP

FIOCRUZ

Objetivo da Pesquisa:

Objetivo Primário:

Investigar aspectos da saúde sexual e reprodutiva de mulheres vivendo com HIV/Aids (MVHA) $\theta$ comparando-os com mulheres soronegativas para o HIV (MNHA).

Objetivo Secundário:

1. Comparar caracteristicas sociodemográficas e de comportamento sexual e reprodutivo de MVHA e MNVHA, incluindo acesso e uso de métodos contraceptivos, ocorrência de gravidez năo planejada, e histórico de interrupçâo de gestaçâo ; 2 . Descrever e comparar a proporção de MVHA e MNVHA que relatam situaçōes de violência psicológica, fisica elou sexual sofrida e a associaçăo desses episódios com aspectos da saúde sexual $\mathrm{e}$

reprodutiva de MVHA e MNVHA; 3. Entre MVHA, investigar a especificidade da infecçăo pelo HIVIAIDS nas decisōes e práticas relacionadas à vida sexual e reprodutivas dessas muiheres; 4 . Investigar a associaçäo de caracteristicas dos serviços de saúde e da assistência à saúde sexual e reprodutiva de MVHA e MNVHA com suas práticas/decisóes contraceptivas e reprodutivas; 5 . Investigar e comparar entre MVHA e MNVHA os

fatores individuais, relacionais, sociais e programáticosfinstitucionais associados às práticas contraceptivas em uso, à ocorrancia de gravidez náoplanejada $e$ ao histórico de interrupçăo de gestaçăo.

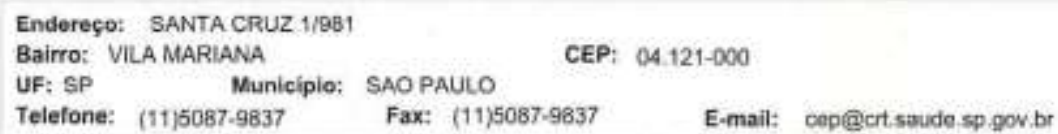




\section{CENTRO DE REFERÊNCIA E TREINAMENTO DST/AIDS}

Avaliaçăo dos Riscos e Beneficios:

Riscos:

Embora a presente pesquisa não utilize nenhum procedimento fisico invasivo, tais como coleta de sangue ou exames físicos, as preocupaçōes de ordem ética estāo presentes na própria concepçăo do projeto. Os riscos envolvidos poderāo ser de ordem psicológica e incluem a perda de privacidade, o desconforto $\theta$ recusa a responder questóes sensiveis. As participantes terâo o direito de se recusar a responder qualquer queståo.

Beneficios:

Năo há beneficios especificos do estudo, entretanto, as participantes poderăo obter, ao participar do estudo, referência, por exemplo, de serviços

prestados por ONGs e serviços de saúde a mulheres em situaçăo de violência física e/ou sexual no municipio de Sâo Paulo.

\section{Comentários e Consideraçōes sobre a Pesquisa:}

0 estudo é pertinente e relevante do ponto de vista cientifico, podendo ampliar o conhecimento em relação às necessidades sexuais e a vida reprodutiva das mulheres vivendo com AIDS.

Consideraçōes sobre os Termos de apresentação obrigatória:

Termos adequados para a conduçąo do estudo.

Recomendaçóes:

Conclusôes ou Pendẽncias e Lista de Inadequaçôes:

Projeto Aprovado

Situaçāo do Parecer:

Aprovado

Necessita Apreciação da CONEP:

Nāo

Consideraçōes Finais a critério do CEP:

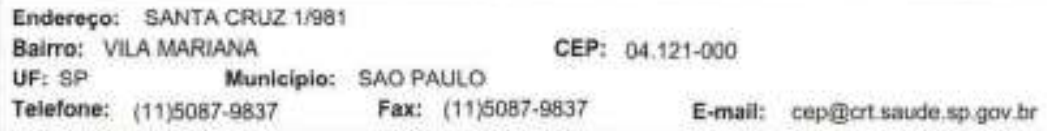




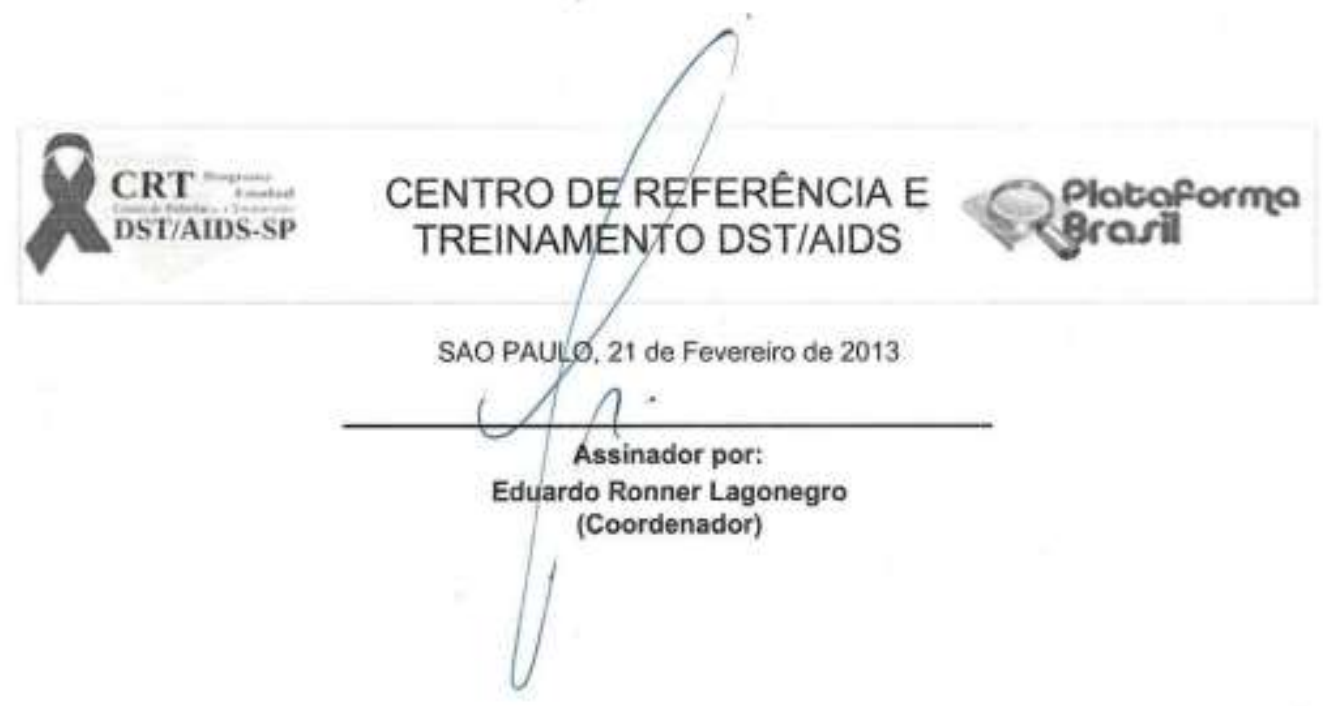

Endereço: SANTA CRUZ 1/981

Bairro: VILA MARIANA

CEP: $04.121-000$

UF: SP Municipio: SAOPAULO

Telefone: (11)5087.9837

Fax: (11)5087-9837

E-mail: cop@ortsaudesp.gov.br 
SECRETARIA DE ESTADO DA SAÚDE

Coordenadoria de Controle de Doenças

Centro de Referéncia e Treinamento DST/Aids

Rua Santa Cruz, 81 - Vila Mariana - Săs Paulo-SP

CEP $(1412 i-000)$ - Fone $5087-091\}$

Săo Paulo, 09 de novembro 2011

Oficio CRT- DST/AIDS - CEP N ${ }^{\circ} 107 / 2011$

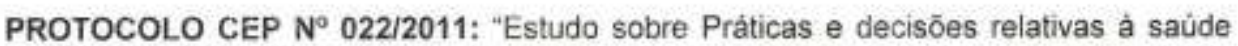
Sexual e Reprodutiva no contexto da epidemia de HIVIAIDS no municipio de Sāo Paulo".

\section{Parecer: APROVADO}

Prezada Investigadiora.

Após a análise do documento do estudo acima referido, pelos membros deste Comité, em reuniăo ordinária do dia 07 de novembro de 2011, foi emitido parecer: APROVADO.

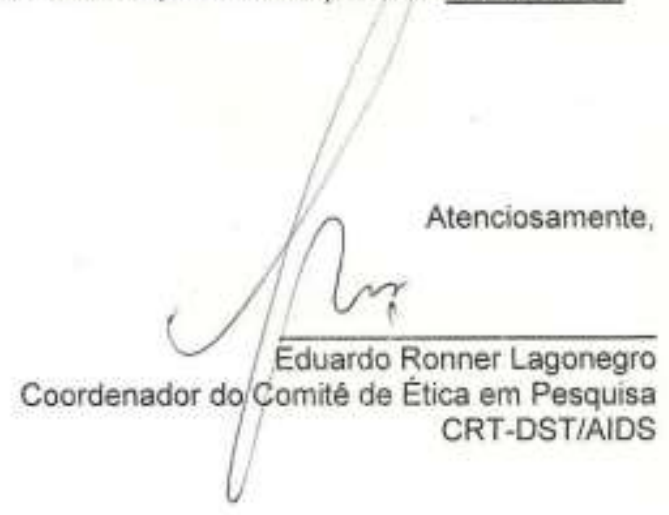

Ilima Sra.

Prof ${ }^{a}$. Dr ${ }^{a}$ Regina Maria Barbosa.

Investigadora Principal 
SECRETARIA MUNICIPAL DA SAÚDE

Comitê de Ética em Pesquisa/SMS

CAAE: $0043 / 12 *$

Săo Paulo, 14 de Setembro de 2012

IIma. Sra.

Regina Maria Barbosa

PARECER N $143 / 12$ - CEP/SMS

Projeto de Pesquisa Titulo: Estudo sobre práficas e decisôes relafivas á saúde sexual e reprodutiva no contexto da epidemia de HIV/AIDS no municipio de SCo Paúo

Pesquisador responsável: Regina Maria Barbasa

Instifuiçāo: Fundaçăo de Desenvolvimento da Unicamp (FUNCAMP)

Local onde os dados serāo coletados: serviços da Rede Municipal Especializadia em DST/AlOS e unidades da Atençào Bádica.

\section{1 - Sumário Geral do Protocolo}

Introduçäo/justificativa: Desde o ano 2000, para cada três casos notificodos entre os homens existem dois entre mulheres, proporçao que tern se mantido estável, sendo a transmissōo sexual responsável por mais de $90 \%$ dos casos notificados no pais entre individuos com mais de 12 anos (BRASIL 2010). Atuaimente, a atençāo à saúde da mulher com HIV continuo centrada no aspecto reprodutivo de protecăo á maternidode, com a introduç̋o da prevenç̋o da fransmissōo vertical. Desta forma, a inexisténcia ou insuficiérncia de politicas públicas que efetivem - direito oo aceso a serviços de saúde sexual e reprodutiva mostra a fraglidade desses serviços em propor estratégias de reduçāo de risco. Além disso, a literatura internacional apresenta dados controversos com relaçāo d̀ faxa de fecundidade e evidencia cinda que mulheres que engravidam apds o diagnóstico de HIV, opresentam menor uso de métodos contraceptivos e menor conhecimento sobre a transmissdo vertical.

Objetivos: investigar aspectos da saúde sexual e reprodutiva de mulheres vivendo com HIV/AIDS (MVHA) e compará-los com mutheres soronegativas para HIV (MNHA). Especial atençảo será dada a influencia de dimensōes do contexto sccial e relacional dessas mutheres, particularmente a presença de situaçōes de violência de gênero solrida, e do contexto insfifucional de cuidado á saúde nas práticas sexuais e reprodufivas de mulheres de ambos os grupos.

Metodologia: Estudo quantitativo de carte transversal será condustido no municipio de São Paulo para comporar duas amostras representafivas de MVHA e MNHA usuárias dos serviços públicos de saúde.

A populaçao do estudo será composta por mulheres entre 18 e 49 anos matriculados e usuárías regulares dos servicos públicos de saúde selecionados para compor a amostra, lacalizados nos município de São Paulo.

O tamanho da amostra foi estimado em 900 para cada grupo de mulheres, totalizando 1800 voluntérios. Um número adicional de entrevistos (10\%) será conduzido como margem de segurança relativa o eventucis perdics devido á recusa de entrevista. Consta que haverá sartelo dos unidades e antes de iniciar o frabalho de campo serd́ envioda uma lista dos serviços para o CEp fomar conhecimento.

Serăo realizadas entrevistos automatizadas aplicadas por um treinodor treinado com auxillo de um computador. Os questionários têm como objetivo coletar dados sociodemográficos e comportamentais (modelo anexo). Na Sessāo 10 (Histórico da soroposifividade ao HIV e diagnóstico de ADS) consta que será levantado o diagnóstico de AiDS no registro informatizado dos serviços de saúde mediante a informaçáo do número de prontucrio.

Análise dos dados: os resultados dos questionários preenchidos nos computodores de bolso serdo fransferidos diretamente para a central de gerenciamento, onde poderá ser checada a completude das entrevistas. Há programaçăo para que nōo haja possibilidade de informaçāo em branco.

Serd́ feita análise comparativa entre os 2 grupos de mutheres utilizando testes estatísticos como Qu quodrado, Fisher. McNemar. O NEPO sedicrá o projeto e oferecerá a infraestrutura necessária. Haverá dois supervisores de campo, um profissional responsável pelo monitoramento e controle de qualidade, um profissianal responsável pela organizaçōo e limpeza do banco. As entrevistas serōo conduzzidas por mulheres que passaróo por uma capacitaçốo (selecionados pelo coordenador e pesquisador do estudio). Na póg. 28 sōo mencionados 8 entrevistadores. Consta que os resultados serõo apresentados em relatório a CNPq.

\section{2-Consideraçōes.}

"Rua General Jardim, 36 - $1^{\circ}$ andar -V. Buarque - fone: 3397.2464-email: smscep@gmail.com http://www.prefeitura.sp.gov,br/cidade/secretarias/saude/comite_de_etical 


\section{SECRETARIA MUNICIPAL DA SAÚDE \\ Comitê de Ética em Pesquisa/SMS}

CAAE: 0043/12*

O estudo è pertinente e relevante do ponto de vista cientifico, podendo ampliar o corhecimento em relaçăo ás necessidades sexuais e a vida reprodutiva das mulheres vivendo com ADS.

Documentos apresentados:

- Cópla da Folha de Rosto;

- Cópia do parecer de aprovaçäo, emitido pelo CEP do CRT DST/AIDS:

- Orçamento-compativel com o projeto, o CNPa patrocinará o projeto.

- Cronograma atualizado informa coleta dos dados a partir de outubro de 2012

\section{Avaliaçāo dos Riscos e Benefícios}

A metodología 6 adequada aos objetivos. O risco é justificado no deseniho da pesquisc, demonstranda a preocupaçāo em treinar as entrevistadoras de modo a evitar constrangimento das mulheres sujeito da pesquisa. Os pesquisadores se comprometem com o sigilo dos informaçōes acessadas e relatam que os entrevistadores também serôo orientados com reloçōo a isso.

Termo de Consentimento Livre e Esclarecido (TCLE)

O TCLE está eloborado de forma objetiva e em ínguagem acessivel, fol mencianodo direlto a recusa e sigilo. Considerado adequado após retificado.

\section{III - Situaçāo do Protocolo - APROVADO}

Para inicio da coleta dos dados, o pesquisador deverá se apresentar na mesma instáncia que autorizou a realizaç̧o do estudo (Coordenadoria, Supervisáo, SMS/Gab, etc).

o sujeito de pesquisa (ou seu representante) e o pesquisador responsável deveráo rubricar todas as folhas do Termo de Consentimento Livre e Esclarecido - TCLE apondo sua assinatura na última página do referido Termo, conforme Carta Circular no o03/2011 da CONEP/CNS.

Salientamos que o pesquisador deve desenvolver a pesquisa conforme delineada no protocolo aprovado. Eventuais modificaçōes ou emendas ao protocolo devem ser apresentadas ao CEP de forma clara e sucinta, identificando a parte do protocolo a ser modificada e suas justificativas.

Ao pesquisador cabe manter em arquivo, sob sua guarda, por 5 anos, os dados da pesquisa, contendo fichas individuais e todos os demais documentos recomendados pelo CEP (Res. CNS 196/96 item IX, 2.e).

Uma cópla digital (CD/DVD) do projeto finalizado deverá ser enviada ao CEP e outra à instância que autorizou a realizaçăo do estudo, vla correio ou entregue pessoaimente, logo que o mesmo estiver concluido.

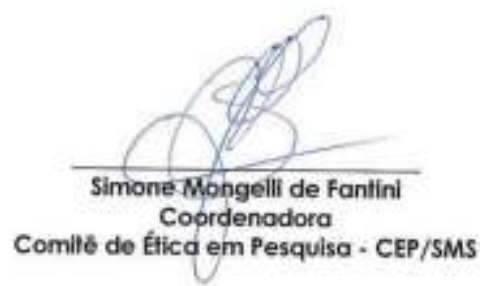

* Rua Ceneral Jardim, 36 - ${ }^{\circ}$ andar - V. Buarque - fone: 3397.2464 - email: smscep@gmailcom http://www.prefeltura.sp.gov.br/cidade/secretarias/saude/comite_de_etica/ 


\section{UNIVERSIDADE FEDERAL DE SÃO PAULO - UNIFESP/ HOSPITAL SÃO PAULO

\section{PARECER CONSUBSTANCIADO DO CEP}

Elaborado pela Instituição Coparticipante

\section{DADOS DO PROJETO DE PESQUISA}

Titulo da Pesquisa: Estudo sobre práticas e decisões relativas à saúde sexual e reprodutiva no contexto da epidemia de HIVIAIDS no município de São Paulo - Estudo GENIH

Pesquisador: Regina Maria Barbosa

Área Temática:

Versão: 4

CAAE: 11712112.6 .0000 .5375

Instituição Proponente: Centro de Referencia e Treinamento DST/AIDS

Patrocinador Principal: Conselho Nacional de Desenvolvimento Cientifico e Tecnologico ((CNPq))

\section{DADOS DO PARECER}

Número do Parecer: 215.121

Data da Relatoria: 22/03/2013

Apresentação do Projeto:

O projeto propõe investigar aspectos da saúde sexual e reprodutiva de mulheres vivendo com HIVIAids (MVHA) e comparando-os com mulheres soronegativas para o HIV, ou não vivendo com HIVIAids (MNVHA). Especial atenção será dada à influência de dimensões do contexto social e relacional dessas mulheres, particularmente a presença de situações de violência de gênero sofrida, e do contexto institucional de cuidado à saúde nas práticas sexuais e reprodutivas de mulheres de ambos os grupos. $O$ estudo é quantitativo de corte transversal será conduzido no município de São Paulo para comparar duas amostras representativas de MVHA e MNVHA usuárias dos serviços públicos de saúde. A população do estudo será composta por 2.000 mulheres entre 18 e 49 anos matriculadas e usuárias regulares dos serviços públicos de saúde selecionados para compor a amostra, localizados no município de São Paulo, Brasil. Atualmente, a atenção à saúde da mulher com HIV está centrada basicamente no aspecto reprodutivo de proteção à maternidade, com a introdução da prevenção da transmissão vertical. Desta forma, a inexistência ou insuficiência de políticas públicas que efetivem o direito ao acesso a serviços de saúde sexual e reprodutiva demonstra a fragilidade desses serviços em propor estratégias de redução de risco. $O$ estudo pretende contribuir para melhorar as ações de cuidado à saúde sexual e reprodutiva de mulheres vivendo com HIV, no sentido do respeito às suas escolhas reprodutivas e da garantia de que estas poderão ocorrer de modo seguro. Nesse sentido, este estudo alinha-se com as diretrizes do Plano Integrado de Enfrentamento da Epidemia de Aids, elaborado pelo Ministério da Saúde, em

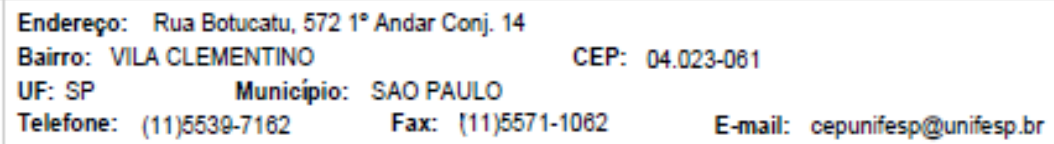




\section{UNIVERSIDADE FEDERAL DE SÃO PAULO - UNIFESP/ HOSPITAL SÃO PAULO}

parceria com a Secretária de Políticas para as Mulheres (Brasil, 2009).Objetivo Primário: Investigar aspectos da saúde sexual e reprodutiva de mulheres vivendo com HIVIAids (MVHA) e comparando-os com mulheres soronegativas para o HIV (MNHA). Especial atenção será dada à influência de dimensões do contexto social e relacional dessas mulheres, particularmente a presença de situações de violência de gênero sofrida, e do contexto institucional de cuidado à saúde nas práticas sexuais e reprodutivas de mulheres de ambos os grupos.

Objetivo da Pesquisa:

Objetivo Primário:

Investigar aspectos da saúde sexual e reprodutiva de mulheres vivendo com HIVIAids (MVHA) e comparando-os com mulheres soronegativas para o HIV (MNHA).

Objetivo Secundário:

1. Comparar características sociodemográficas e de comportamento sexual e reprodutivo de MVHA e MNVHA, incluindo acesso e uso de métodos contraceptivos, ocorrência de gravidez não planejada, e histórico de interrupção de gestação ; 2 . Descrever e comparar a proporção de MVHA e MNVHA que relatam situações de violência psicológica, física e/ou sexual sofrida e a associação desses episódios com aspectos da saúde sexual e reprodutiva de MVHA e MNVHA; 3 . Entre MVHA, investigar a especificidade da infecção pelo HIVIAIDS nas decisões e práticas relacionadas à vida sexual e reprodutivas dessas mulheres; 4. Investigar a associação de características dos serviços de saúde e da assistência à saúde sexual e reprodutiva de MVHA e MNVHA com suas práticas/decisões contraceptivas e reprodutivas; 5 . Investigar e comparar entre MVHA e MNVHA os fatores individuais, relacionais, sociais e rogramáticos/institucionais associados às práticas contraceptivas em uso, à ocorrência de gravidez nãoplanejada e ao histórico de interrupção de gestação.

Avaliação dos Riscos e Benefícios:

riscos e beneficios adequadamente apresentados

Comentários e Considerações sobre a Pesquisa:

Pesquisa já aprovada pelo CEP DST AIDS- CENTRO DE TREINAMENTO E pelo CEP da Secretaria Municipal da Saude de São Paulo

Considerações sobre os Termos de apresentação obrigatória:

Documentos apresentados de forma adequada.

Recomendações:

não se aplica

Endereço: Rua Botucatu, $5721^{\circ}$ Andar Conj. 14
$\begin{aligned} & \text { Bairro: VLA CLEMENTINO } \\ & \text { UF: SP }\end{aligned} \quad \begin{array}{llll}\text { Municipio: } & \text { SAO PAULO } & \text { CEP: } 04.023-061 \\ \text { Telefone: } & \text { (11)5539-7162 } & \text { Fax: }(11) 5571-1062 & \text { E-mail: cepunifesp@unifesp.br }\end{array}$




\title{
UNIVERSIDADE FEDERAL DE \\ SÃO PAULO - UNIFESP/ \\ Plataforma HOSPITAL SÃO PAULO
}

Conclusões ou Pendências e Lista de Inadequações:

Sem inadequações.

Situação do Parecer:

Aprovado

Necessita Apreciação da CONEP:

Não

Consideraçôes Finais a criterio do CEP:

$O$ colegiado acata o parecer do relator

SAO PAULO, 08 de Março de 2013

Assinador por:

José Osmar Medina Pestana

(Coordenador)

\author{
Endereço: Rua Botucatu, $5721^{\circ}$ Andar Conj. 14 \\ Bairro: VILA CLEMENTINO \\ CEP: $04.023-061$ \\ UF: SP Município: SAO PAULO \\ Telefone: (11)5539-7162 Fax: (11)5571-1062 \\ E-mail: cepunifesp@unifesp.br
}




\section{INSTITUTO DE INFECTOLOGIA Platoforma EMÍLIO RIBAS - IIER}

\section{PARECER CONSUBSTANCIADO DO CEP}

Elaborado pela Instituição Coparticipante

\section{DADOS DO PROJETO DE PESQUISA}

Titulo da Pesquisa: Estudo sobre práticas e decisões relativas à saúde sexual e reprodutiva no contexto da epidemia de HIVIAIDS no município de São Paulo - Estudo GENIH

Pesquisador: Regina Maria Barbosa

Área Temática:

Versão: 4

CAAE: 11712112.6 .0000 .5375

Instituição Proponente: Centro de Referência e Treinamento DST/AIDS

Patrocinador Principal: Conselho Nacional de Desenvolvimento Cientifico e Tecnologico ((CNPq))

\section{DADOS DO PARECER}

Número do Parecer: 227.627

Data da Relatoria: 06/03/2013

\section{Apresentação do Projeto:}

Estudo quantitativo de corte transversal será conduzido no município de São Paulo para comparar duas amostras representativas de mulheres vivendo com HIVIAids (MVHA) e mulheres soronegativas para o HIV, ou não vivendo com HIVIAids (MNVHA), usuárias dos serviços públicos de saúde. População do estudo será composta por mulheres entre 18 e 49 anos matriculadas e usuárias regulares dos serviços públicos de saúde selecionados para compor a amostra, localizados no município de São Paulo, Brasil. O município de São Paulo foi escolhido, pois concentra o maior número de casos notificados de AIDS e maior número de gestantes soropositivo do Estado e do país, bem como maior número de estabelecimentos voltados ao atendimento de pessoas vivendo com HIVIAIDS. O estudo será conduzido em unidades de saúde selecionadas para compor a amostra, de diferentes graus de complexidade, tamanho da clientela $e$ localização geográfica, que compõem a rede municipal e/ou estadual de serviços públicos de saúde localizados no município de São Paulo. Para a seleção de MVHA, uma amostra de unidades públicas de saúde de referência para o atendimento de mulheres vivendo com HIVIAIDS será selecionada. Para compor - grupo de MNVHA, será selecionada uma amostra de unidades públicas de saúde, de diferentes graus de complexidade (hospitais, centros de atenção à saúde da mulher, unidades básicas de saúde, unidades do programa de saúde da família e ambulatórios de assistência) e tamanho da clientela, localizadas nas mesmas coordenadorias de saúde das unidades selecionadas para amostragem de MVHA. O tamanho da amostra foi estimado em 900

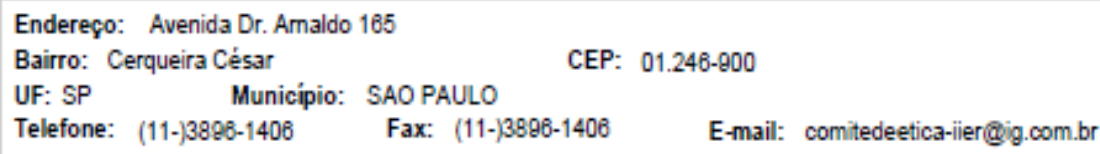




\title{
INSTITUTO DE INFECTOLOGIA Platoforma EMÍLIO RIBAS - IIER
}

para cada grupo de mulheres, MVHA e MNVHA, já considerando o efeito do delineamento por amostragem complexa (deff) igual a 1,6. Com esta amostra será possivel detectar diferenças estatísticas a um nível de significância ( $($ ) $5 \%$ e poder do teste $(1-i)$ de $80 \%$ entre os grupos nas principais variáveis investigadas. A estratégia amostral utilizada será por conglomerados em dois estágios com probabilidade proporcional ao tamanho dos conglomerados. A seleção das mulheres, após o sorteio das unidades de saúde para ambos os grupos, será realizada de modo sistemático de forma a garantir a representatividade da amostra. A coleta de dados será realizada por meio de entrevistas aplicadas por um entrevistador treinado, com auxílio de um computador de bolso (Handheld-Assisted Personal Interview HAPI). As respostas dadas serão gravadas em uma base de dados gerada automaticamente pelo software e transferidas para a coordenação geral do estudo. Os dados serão, então, transferidos para o software STATA 10.0 para as análises estatísticas.

Tamanho da Amostra no Brasil: 2.000

Mulheres vivendo com HIV: 1000

Mulheres não vivendo com HIVIAids: 1000

Critério de Inclusão: Ter entre 18 e 49 anos Concordar em participar da pesquisa.

Não haverá uso de fontes secundárias de dados (prontuários, dados demográficos, etc).

\section{Cronograma:}

Elaboração do plano amostral: 01/08/2012 a 21/12/2012

Elaboração do instrumento de pesquisa: 01/08/2012 a 21/12/2012

Treinamento dos entrevistadores: 21/01/2013 a 07/02/2013

Coleta dos dados: 18/02/2013 a 30/09/2013

Analise preliminar dos dados: 01/10/2013 a 29/11/2013

Elaboração de relatório: 02/12/2013 a 27/12/2013

Manter sigilo da integra do projeto de pesquisa: Sim Prazo: Até a publicação dos resultados Justificativa da Emenda: Inclusão de nova instituição coparticipante - EPM/UNIFESP.

Objetivo da Pesquisa:

Objetivo Primário:

Investigar aspectos da saúde sexual e reprodutiva de mulheres vivendo com HIVIAids (MVHA) e comparando-0s com mulheres soronegativas para o HIV (MNHA). Especial atenção será dada à

\author{
Endereģo: Avenida Dr. Arnaldo 185 \\ Bairro: Cerqueira César CEP: $01.246-900$ \\ UF: SP Município: SAOPAULO \\ Telefone: (11-)3886-1406 Fax: (11-)3896-1406 E-mail: comitedeetica-iier@ig.com.br
}




\section{INSTITUTO DE INFECTOLOGIA Platoforma EMÍLIO RIBAS - IIER}

influência de dimensões do contexto social e relacional dessas mulheres, particularmente a presença de situações de violência de gênero sofrida, e do contexto institucional de cuidado à saúde nas práticas sexuais e reprodutivas de mulheres de ambos os grupos.

Objetivo Secundário:

1. Comparar características sociodemográficas e de comportamento sexual e reprodutivo de $\mathrm{MVHA}$ e MNVHA, incluindo acesso e uso de métodos contraceptivos, ocorrência de gravidez não planejada, e histórico de interrupção de gestação;

2. Descrever e comparar a proporção de MVHA e MNVHA que relatam situações de violência psicológica, física e/ou sexual sofrida e a associação desses episódios com aspectos da saúde sexual e reprodutiva de MVHA E MNVHA;

3. Entre MVHA, investigar a especificidade da infecção pelo HIVIAIDS nas decisões e práticas relacionadas à vida sexual e reprodutivas dessas mulheres;

4. Investigar a associação de características dos serviços de saúde e da assistência à saúde sexual e reprodutiva de MVHA e MNVHA com suas práticas/decisões contraceptivas e reprodutivas;

5. Investigar e comparar entre MVHA e MNVHA os fatores individuais, relacionais, sociais e programáticos/institucionais associados às práticas contraceptivas em uso, à ocorrência de gravidez não planejada e ao histórico de interrupção de gestação.

\section{Avaliação dos Riscos e Beneficios:}

Riscos: Embora a presente pesquisa não utilize nenhum procedimento físico invasivo, tais como coleta de sangue ou exames físicos, as preocupações de ordem ética estão presentes na própria concepção do projeto. Os riscos envolvidos poderão ser de ordem psicológica e incluem a perda de privacidade, 0 desconforto e recusa a responder questões sensiveis. As participantes terão o direito de se recusar a responder qualquer questão.

Benefícios: Não há benefícios específicos do estudo, entretanto, as participantes poderão obter, ao participar do estudo, referência, por exemplo, de serviços prestados por ONGs e serviços de saúde a mulheres em situação de violência física e/ou sexual no município de São Paulo.

\section{Comentários e Considerações sobre a Pesquisa:}

Pesquisa de relevância para a saúde pública.

Estudo que será realizado em diferentes unidades de saúde e foram apresentadas as devidas aprovações pelos respectivos CEPs.

Considerações sobre os Termos de apresentação obrigatória:

O TCLE apresentado está escrito de tal forma que contempla todos os sujeitos de pesquisa de

Endereço: Avenida Dr. Arnaldo 165

Bairro: Cerqueira César CEP: $01.246-900$

UF: SP Municipio: SAOPAULO

Telefone: (11-)3896-1406 Fax: (11-)3896-1406 E-mail: comitedeetica-iler@ig.com.br 


\section{INSTITUTO DE INFECTOLOGIA Platoforma EMÍLIO RIBAS - IIER}

todos os centros participantes. Está em linguagem clara e compreensivel aos participantes e contém as informações necessárias para os esclarecimentos aos sujeitos da pesquisa.

Recomendações:

Näo se aplica.

Conclusões ou Pendências e Lista de Inadequaçöes:

Não se aplica.

Situação do Parecer:

Aprovado

Necessita Apreciaçäo da CONEP:

Não

Consideraçôes Finais a critério do CEP:

Os pesquisadores responsáveis no Instituto de Infectologia Emílio Ribas deverão entregar uma cópia deste parecer de aprovação, juntamente com uma cópia do projeto, na Seção de Pesquisa e Trabalhos Científicos da Divisão Científica e aguardar pela emissão da "Autorização para Início do Estudo".

SAO PAULO, 24 de Março de 2013

Assinador por:

Anna Christina Nunes D'Ambrosio

(Coordenador)

Endereço: Avenida Dr. Arnaldo 165

Bairro: Cerqueira César
UF: SP $\quad$ Município: SAO PAULO CEP: $01.246-900$

Telefone: (11-)3896-1406 Fax: (11-)3896-1406 E-mail: comitedeetica-iier@ig.com.br 


\section{INSTITUTO DE INFECTOLOGIA Platoforma EMÍLIO RIBAS - IIER \\ Bravil}

\section{PARECER CONSUBSTANCIADO DO CEP}

Elaborado pela Instituição Coparticipante

\section{DADOS DO PROJETO DE PESQUISA}

Titulo da Pesquisa: Estudo sobre práticas e decisões relativas à saúde sexual e reprodutiva no contexto da epidemia de HIVIAIDS no município de São Paulo - Estudo GENIH

Pesquisador: Regina Maria Barbosa

Área Temática:

Versão: 5

CAAE: 11712112.6 .0000 .5375

Instituição Proponente: Centro de Referência e Treinamento DST/AIDS

Patrocinador Principal: CONS NAC DE DESENVOLVIMENTO CIENTIFICO E TECNOLOGICO

\section{DADOS DO PARECER}

Número do Parecer: 362.695

Data da Relatoria: $22 / 05 / 2013$

\section{Apresentação do Projeto:}

Estudo quantitativo de corte transversal será conduzido no município de São Paulo para comparar duas amostras representativas de MVHA e MNVHA usuárias dos serviços públicos de saúde. A população do estudo será composta por 2.000 mulheres entre 18 e 49 anos usuárias regulares dos serviços públicos de saúde selecionados para compor a amostra, localizados no município de São Paulo, Brasil.

Estudo conduzido em unidades de saúde, de diferentes graus de complexidade, que compõem a rede municipal e/ou estadual de serviços públicos de saúde. Uma amostra de unidades públicas de saúde de referência para o atendimento de mulheres vivendo com HIVIAIDS será selecionada (MVHA) e para compor o grupo de mulheres soronegativas para o HIV, ou não vivendo com HIVIAids (MNVHA), será selecionada unidades públicas de saúde.

O tamanho da amostra foi estimado em 900 para cada grupo de mulheres, MVHA e MNVHA, já considerando o efeito do delineamento por amostragem complexa (deff) igual a 1,6. Com esta amostra será possivel detectar diferenças estatísticas a um nível de significância $5 \%$ e poder do teste $(1-i)$ de $80 \%$ entre os grupos nas principais variáveis investigadas. Assim, ao propor investigar as especificidades das MVHA no que concerne à saúde sexual e reprodutiva, o presente estudo pretende contribuir para melhorar as ações de cuidado à saúde sexual e reprodutiva de

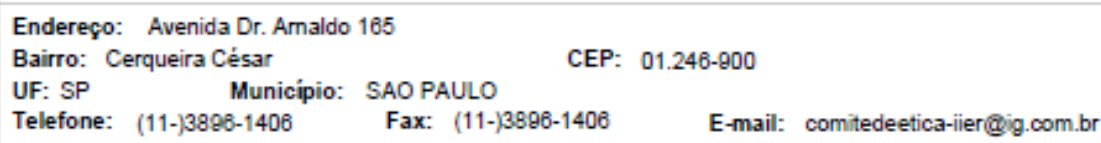




\section{INSTITUTO DE INFECTOLOGIA Platoforma EMÍLIO RIBAS - IIER}

Contnuaçăo do Parecer. 362.695

mulheres vivendo com HIV, no sentido do respeito às suas escolhas reprodutivas e da garantia de que estas poderão ocorrer de modo seguro.

Amostra utilizada será por conglomerados em dois estágios com probabilidade proporcional ao tamanho dos conglomerados. A seleção das mulheres, após o sorteio das unidades de saúde para ambos os grupos, será realizada de modo sistemático de forma a garantir a representatividade da amostra. A coleta de dados será realizada por meio de entrevistas aplicadas por um entrevistador treinado, com auxílio de um computador de bolso (Handheld-Assisted Personal Interview HAPI). As respostas dadas serão gravadas em uma base de dados gerada automaticamente pelo software e transferidas para a coordenação geral do estudo. Os dados serão, então, transferidos para o software STATA 10.0 para as análises estatísticas.

Instituição Responsável: NEPO ¿ Núcleo de Estudos da População/UNICAMP

Instituições Parceiras: Centro de Treinamento em DST/AIDS da Secretaria de Estado da Saúde de São Paulo; Área Técnica de Saúde da Mulher da Secretaria de Estado da Saúde de São Paulo; Programa Municipal de DST/AIDS - São Paulo; Instituto de Infectologia Emilio Ribas ¿ IIER; Instituto de Saúde - São Paulo; FIOCRUZ.

Critério de Inclusão:Ter entre 18 e 49 anos Concordar em participar da pesquisa.

Manter sigilo da integra do projeto de pesquisa: Sim - Prazo: Até a publicação dos resultados

Justificativa da Emenda: Foram incorporados ao projeto: 1)um plano de recrutamento; 2) autorização de contato com as mulheres por telefone; 3) detalhamento de questões éticas relativas ao recrutamento; 4) um componente qualitativo e o respectivo TCLE para realização de entrevistas com profissionais de saúde.

Objetivo da Pesquisa:

Objetivo Primário: Investigar aspectos da saúde sexual e reprodutiva de mulheres vivendo com HIVIAids (MVHA) e comparando-os com mulheres soronegativas para o HIV (MNHA). Especial atenção será dada à influência de dimensões do contexto social e relacional dessas mulheres,

Endereço: Avenida Dr. Arnaldo 165

Bairro: Cerqueira César CEP: $01.246-900$

UF: SP Município: SAO PAULO

Telefone: (11-)3896-1406 Fax: (11-)3896-1406 E-mail: comitedeetica-iler@ig.com.br 


\section{INSTITUTO DE INFECTOLOGIA Platoforma EMÍLIO RIBAS - IIER}

Contnuaçato do Parecer. 362.695

particularmente a presença de situações de violência de gênero sofrida, e do contexto institucional de cuidado à saúde nas práticas sexuais e reprodutivas de mulheres de ambos os grupos.

Objetivo Secundário:

1. Comparar características sociodemográficas e de comportamento sexual e reprodutivo de MVHA e MNVHA, incluindo acesso e uso de métodos contraceptivos, ocorrência de gravidez não planejada, e histórico de interrupção de gestação; 2.Descrever e comparar a proporção de MVHA e MNVHA que relatam situações de violência psicológica, física e/ou sexual sofrida e a associação desses episódios com aspectos da saúde sexual e reprodutiva de MVHA e MNVHA; 3.Entre MVHA, investigar a especificidade da infeç̧ão pelo HIVIAIDS nas decisões e práticas relacionadas à vida sexual e reprodutivas dessas mulheres;

4.Investigar a associação de características dos serviços de saúde e da assistência à saúde sexual e reprodutiva de MVHA e MNVHA com suas práticas/decisões contraceptivas e reprodutivas; 5 .Investigar e comparar entre MVHA e MNVHA os fatores individuais, relacionais, sociais e programáticos /institucionais associados às práticas contraceptivas em uso, à ocorrência de gravidez não planejada e ao histórico de interrupção de gestação.

\section{Avaliação dos Riscos e Beneficios:}

Riscos: Embora a presente pesquisa não utilize nenhum procedimento físico invasivo, tais como coleta de sangue ou exames físicos, as preocupações de ordem ética estão presentes na própria concepção do projeto. Os riscos envolvidos poderão ser de ordem psicológica e incluem a perda de privacidade, o desconforto e recusa a responder questões sensiveis. As participantes terão o direito de se recusar a responder qualquer questão.

Benefícios: Não há benefícios específicos do estudo, entretanto, as participantes poderão obter, ao participar do estudo, referência, por exemplo, de serviços prestados por ONGs e serviços de saúde a mulheres em situação de violência física e/ou sexual no município de São Paulo.

\section{Comentários e Considerações sobre a Pesquisa:}

ver conclusões e inadequações.

Considerações sobre os Termos de apresentação obrigatória: ver conclusões e inadequações.

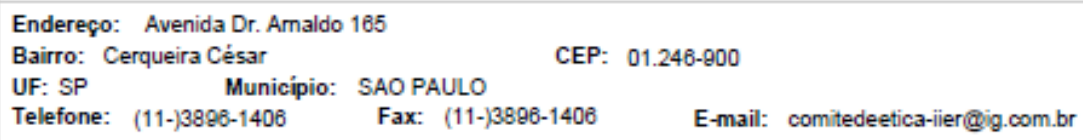




\section{INSTITUTO DE INFECTOLOGIA Platoforma EMÍLIO RIBAS - IIER}

Contnuaç̧̃o do Parecer. 362.695

Recomendações:

ver conclusões e inadequações.

Conclusões ou Pendências e Lista de Inadequaçöes:

1-Inserir os critérios de exclusão.

2-TCLE: inserir o telefone do CEP do IIER

Situação do Parecer:

Não Aprovado

Necessita Apreciação da CONEP:

Näo

Consideraçôes Finais a critério do CEP:

SAO PAULO, 16 de Agosto de 2013

Assinador por:

Anna Christina Nunes D'Ambrosio

(Coordenador) 
ANEXO C

TCLE de participação no estudo

\section{Estudo sobre práticas e decisões relativas à saúde sexual e reprodutiva no contexto da epidemia de HIV/AIDS no município de São Paulo}

Termo de Consentimento Livre e Esclarecido para Participação no Estudo (versão 3)

O Núcleo de Estudos da População da Universidade Estadual de Campinas (UNICAMP), em parceria com o Centro de Treinamento e Referência em DST/AIDS da Secretaria de Saúde do Estado de São Paulo, o Programa Municipal de DST/Aids de São Paulo, o Instituto de Infectologia Emilio Ribas e o ambulatório de Infectologia da Escola Paulista de Medicina, está conduzindo um projeto de pesquisa com mulheres em idade reprodutiva no município de São Paulo, para o qual gostaríamos de contar com a sua participação. Esta pesquisa tem por objetivo investigar aspectos da saúde sexual, reprodutiva e de vida de mulheres e sua relação com a vulnerabilidade à infecção pelo HIV/AIDS.

Sua participação no estudo consiste em responder uma entrevista por meio de um computador sobre as experiências de vida, relacionamentos afetivos e aspectos ligados à saúde. A duração da entrevista será de aproximadamente 45 minutos e será realizada na própria unidade de saúde no horário que melhor convier. Algumas perguntas da entrevista podem fazê-la sentir desconfortável ou fazê-la lembrá-la de assuntos difíceis ou tristes, mas você não precisa respondê-las se não quiser.

Não há benefícios específicos do estudo, entretanto, as participantes receberão, ao participar do estudo, referência de serviços prestados por ONGs e de serviços de saúde, bem como materiais educativos sobre prevenção de doenças sexualmente transmissíveis e AIDS.

Toda e qualquer informação que você fornecer como parte deste estudo será anônima, ou seja, seu nome não será ligado a nenhuma informação dada. Todo o cuidado será tomado pela equipe de pesquisa para que o seu nome seja mantido em segredo. Seu nome será registrado apenas neste documento, que será mantido trancado em armário com chave e apenas a coordenadora geral do estudo terá acesso. Os dados gravados no computador serão protegidos por senha, e neles não haverá seu nome, apenas um número de identificação.

Sua participação neste estudo é voluntária, ou seja, você decide se quer ou não participar. Mesmo tendo decidido participar, você pode mudar de ideia e interromper a participação quando quiser. Se você decidir não participar em alguma parte do estudo ou abandoná-lo, isso não acarretará nenhum prejuízo ao seu atendimento na unidade de saúde. Se você tiver alguma dúvida ou preocupação sobre o estudo, pode contatar a coordenadora do estudo (Regina Maria Barbosa) no número (11) 3521-5907. Se tiver alguma dúvida ou pergunta sobre os aspectos éticos desta pesquisa, ou qualquer denúncia, pode contatar o presidente do Comitê de Ética da UNIFESP, no telefone 5571-1062. 
Declaração de consentimento pós-esclarecido

Eu aceito participar desta pesquisa e tive a oportunidade de ler este documento ou este foi lido para mim. Todas as minhas perguntas foram respondidas satisfatoriamente. Eu entendi o motivo deste estudo, os procedimentos e os riscos e benefícios desses procedimentos. Se eu desejar, posso receber uma cópia assinada deste documento de quem me deu todas essas explicações.

Nome Assinatura Data

\section{Declaração do membro da equipe de pesquisa}

Eu, abaixo assinado, expliquei para a participante os procedimentos a serem realizados durante o estudo e os riscos e benefícios decorrentes desta participação. Eu atesto que ela assinou este termo voluntariamente.

Data Assinatura do Membro da Equipe 